БЕЛОРУССКИЙ ГОСУДАРСТВЕННЫЙ УНИВЕРСИТЕТ

\title{
АКТУАЛЬНЫЕ ПРОБЛЕМЫ МЕЖДУНАРОДНЫХ ОТНОШЕНИЙ И ГЛОБАЛЬНОГО РАЗВИТИЯ
}

СБОРНИК НАУЧНЫХ СТАТЕЙ

Основан в 2013 году

Выпуск 3

Минск

БГУ

2015 
Сборник подготовлен Центром международных исследований факультета международных отношений БГУ. В него вошли научные статьи известных ученых-международников и молодых исследователей.

Статьи посвящены актуальным проблемам современных международных отношений и глобального развития. Книга будет полезна преподавателям, аспирантам, студентам, научным работникам - специалистам в области международных отношений.

Составитель и научный редактор

Е. А. Достанко

Р ед а к и онна я колле гия :

доктор философских наук $A$. М. Байчоров (главный редактор);

доктор исторических наук П. И. Бригадин;

доктор политических наук $B$. H. Ватыль;

доктор политических наук $P$. О. Есин;

доктор философских наук Л. Е. Криштапович;

доктор политических наук Ю. И. Малевич;

доктор политических наук С. В. Решетников;

доктор исторических наук В. Г. Шадурский;

доктор социальных наук Я. Дворак.

(C) БГУ, 2015 


\section{СОДЕРЖАНИЕ}

Предисловие .....................................7

\section{НАУЧНЫЕ СТАТЬИ}

Ватыль В. Н. Идейно-символическое пространство политики

в системе евразийской интеграции: теоретико-

методологический дискурс исследования . . . . . . . . . . 9

Гайдукевич Л. М., Гэ Инь. Деятельность КНР по развитию

международного туризма на современном этапе. . . . . . . . . 25

Гартунг E. В. Международные аспекты энергетической

политики ФРГ в начале XXI века. . . . . . . . . . . . . . . . 38

Го Цзиньлун. «Один пояс - один путь» в отношениях

Китайской Народной Республики и Республики Беларусь . . . . 67

Дворак Я. Н., Савиикайте С. А. Вызовы персонализации

государственных услуг в Литве: возможности и ограничения . . 80

Добровольская В. В. Международное сотрудничество в сфере

высшего образования (сетевая организация деятельности) . . 89

Зантович М. В. Треугольник отношений «США - Япония -

Республика Корея»: оформление нового геополитического

центра в Азиатско-Тихоокеанском регионе . . . . . . . . . . . . 102

Коваленок Д. В. Международное сотрудничество Беларуси

в области таможенного дела в условиях формирования

и развития Евразийского экономического союза . . . . . . . . 116

Ковяко И. И. ГДР во внешней политике

Великобритании в 1979-1989 гг. . . . . . . . . . . . . . 128

Косов А. П. Внешнеполитическая мысль России

о трансформации современной системы

международных отношений . . . . . . . . . . . . . . . 152

Лагун В. А. Анализ контактов руководителей СССР

и Великобритании (1941-1945 гг.) . . . . . . . . . . . . . . . 169 
Матвиенко А. С. Сравнение теоретических обоснований приоритета территориальных прав государства и нации . . . . . 185 Подкопаев B. B. Национальная академия наук Беларуси в системе развития многостороннего международного научнотехнического сотрудничества Республики Беларусь . . . . . . . . 194 Резников И. В. Политические отношения между КНР

и некоторыми государствами Латинской Америки . . . . . . . 218 Рубо О. П. Международное сотрудничество в сфере

изменения климата и позиция Республики Беларусь . . . . . . 233

Свилас С. Ф. Система управления зарубежными связями

Белорусской ССР через призму участия республики

в ЮНЕСКО (1954-1964 гг.) . . . . . . . . . . . . . . . . . 246

Тихомиров А. В. Взаимодействие Республики Беларусь

с ООН (1991-2015 гг.) . . . . . . . . . . . . . . . . . . 261

Толибова Ш. Х. Основные приоритеты внешней политики

Исламской Республики Иран после заключения

соглашения по ядерной программе . . . . . . . . . . . . . . . 277

Чиж А. М. Внутренняя энергетическая политика

Европейского союза в 2006-2014 гг. . . . . . . . . . . . . . . . 292

Ших К. В. Вклад выходцев из Беларуси в становление

Государства Израиль . . . . . . . . . . . . . . . . . . . . 308

\section{НАУЧНЫЕ ПУБЛИКАЦИИ}

\section{Рецензии}

Shavialiou D. Some Words about Politics in the European $«$ Powder Keg» ...................... 318 


\section{CONTENT}

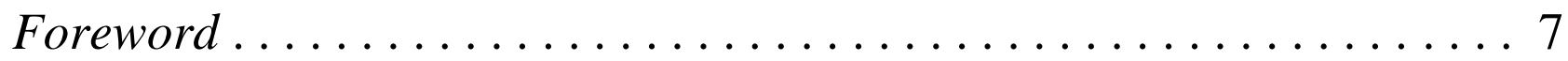

\section{RESEARCH PAPERS}

Vatyl Viktar. The ideological and symbolic space of policy

in the system of the Eurasian integration: theoretical

and methodological discourse of study . . . . . . . . . . . . 9

Gaydukevich Leonid, Ge Yin. The activities of China

on development of international tourism at the present time ..... 25

Gartung Ekaterina. International aspects of the energy policy

of the Federal Republic of Germany

in the beginning of the 21 st century $\ldots \ldots \ldots \ldots \ldots \ldots \ldots \ldots$

Guo Jinlong. «One belt - one way» in relations between

the People's Republic of China and Republic of Belarus ........ 67

Dvorak Jaroslav, Savickaite Samanta. Challenges in personalization

of public services in Lithuania: possibilities and limitations . . . . 80

Dabravolskaya Veranika. International cooperation in the field

of higher education (network organization of activities) . . . . . 89

Zantovich Maria. Triangle relations between

the US - Japan - South Korea: the formation

of a new geopolitical center in the Asia-Pacific region ..........102

Kavalionak Dzmitry. International cooperation of Belarus

in the field of customs affairs in conditions of the formation

and development of the Eurasian Economic Union ............116

Kaviaka Iryna. The German Democratic Republic

in the foreign policy of Great Britain in the years 1979-1989 . . . . 128

Kosov Alexander. Russian foreign policy thinking

about the transformation of the contemporary system

of international relations . . . . . . . . . . . . . . . 152

Lahun Uladzislava. The impact of the personal contacts

between leaders on the bilateral relations of the USSR

and the UK in 1941-1945 ....................... 169 
Matvienko Anatolij. The theoretical justification

of the priority of the territorial rights of the state

and nation: a comparative analysis ................ 185

Podkopaev Vladimir. The National Academy of Sciences

in the system of development of multilateral international

scientific and technical cooperation of the Republic of Belarus . . 194

Reznikov Ilya. Political relations between the People's Republic

of China and certain Latin American countries ..............218

Rubo Olesya. International cooperation on climate change

and the position of the Republic of Belarus . ............233

Svilas Svetlana. Governance framework of foreign relations

of the Belarusian SSR through its participation

in UNESCO (1991-2015) . . . . . . . . . . . . . . . . . . 246

Tsikhamirau Aliaksandr. Interaction of the Republic of Belarus

with the United Nations (1991-2015) . . . . . . . . . . . . . . . 261

Tolibova Shabnam. Main priorities of the foreign policy

of the Islamic Republic of Iran after the conclusion

of an agreement on nuclear program . . . . . . . . . . . . . . . 277

Chizh Aliaksandr. Internal Energy Policy

of the European Union in 2006-2014 . . . . . . . . . . . . . . . 292

Shykh Kanstantin. The contribution of immigrants

from Belarus to the establishment of the State of Israel . . . . . . . 208

\section{RESEARCH PUBLICATIONS}

\section{Reviews}

Shavialiou Dzmitry. Some Words about Politics in the European $«$ Powder Keg» ......................... 318 


\section{Предисловие}

Вниманию ученых-международников и политологов представляется третий выпуск научных трудов «Актуальные проблемы международных отношений и глобального развития», который ежегодно готовится Центром международных исследований факультета международных отношений Белорусского государственного университета.

Наши авторы - преподаватели БГУ, Гродненского и Витебского государственных университетов, коллеги из Клайпедского университета (Литва), Института государства и права НАН Украиньл, а также эксперты МИД Республики Беларусь, Государственного таможенного комитета Республики Беларусь, НАН Беларуси.

Статьи освещуают такие актуальные вопросы, как возникновение новых мегарегиональных партнерств, энергетическая политика государств и международных организаций, евразийская интеграция в современной политологии, реализация национальных интересов в многостороннем сотрудничестве. Также представлены исследования по антропологии и политологии международных отношений.

Международное многостороннее сотрудничество служит важным инструментом внешней политики нашей страны. Изучению этого вопроса посвящен ряд статей сборника. Научные результаты, представленнье в них, получень в рамках задания «Эффективность международного многостороннего сотрудничества во внешней политике странь в условиях глобализации и региональной интеграции (на примере Республики Беларусь)» государственной программы научных исследований «История, культура, общество, государство», подпрограмма «История и культура», которое выполнялось в 20142015 г2. Центром международных исследований ФМО БГУ.

Учитывая научную разнонаправленность исследуемых проблем, выражаем надежду, что наш сборник будет интересен академическому и экспертному сообществу.

E. А. Достанко, кандидат политических наук, директор Центра международных исследований факультета международных отношений Белорусского государственного университета 
НАУЧНЫЕ СТАТЬИ 


\section{ИДЕЙНО-СИМВОЛИЧЕСКОЕ ПРОСТРАНСТВО \\ ПОЛИТИКИ В СИСТЕМЕ ЕВРАЗИЙСКОЙ \\ ИНТЕГРАЦИИ: ТЕОРЕТИКО-МЕТОДОЛОГИЧЕСКИЙ \\ ДИСКУРС ИССЛЕДОВАНИЯ*}

\section{B. Н. Ватыль}

доктор политических наук, профессор, заведуюший кафедрой политологии Гродненского государственного университета имени Янки Купаль

УДК 327.01

В качестве ключевого аналитического понятия в обозначенной теме используется термин «идейно-символическое пространство», что обусловлено двумя соображениями. Во-первых, хотя основой политических коммуникаций, несомненно, являются вербально оформленные «идеи», представленные в виде понятий, принципов, концепций, доктрин, программ и т. П., существенную роль в них играют и невербальные способы общения. Причем по мере развития современных технических средств коммуникации, основанных на аудиовизуальных формах представления информации, рациональные способы репрезентации все активнее дополняются чувственно-эмоциональными. По мнению некоторых исследователей, это обстоятельство является причиной очередного «конца идеологий» как упорядоченных «систем верований»: «идеология» вытесняется «имиджеологией»и, что немаловажно, меняется не только круг субъектов, вовлеченных в процесс производства символических форм, но и характер «потребления» последних $[11$, с. $28-36]$.

Таким образом, сфера применения понятия идеологии в его традиционной интерпретации - в качестве набора более или менее целостных и упорядоченных систем, идей и осознанных убеждений, которые служат для определения и оправдания социальных действий, сужается. Правда, в конце XX в. данный концепт был подвергнут реинтерпретации, результатом которой стало понимание идеологии как способа функционирования символических форм (не только идей, но и образов, действий и даже вещей - всего, что может быть наделено

\footnotetext{
* Статья подготовлена в рамках темы ГПНИ «Идейно-символическое пространство политики в системе евразийской интеграции: общее и особенное» (А34-14).
} 
смыслом) в контексте отношений власти, господства, неравенства и т. п. [12]. Однако, как справедливо подчеркивает О. Ю. Маликова, «новые интерпретации пока не стали общепринятыми, мы предпочитаем говорить об идейно-символическом пространстве как совокупности идей, образов, символов, нарративов, мифов и проч.» [5, с. 14]. Оно объединяет способы репрезентации смыслов, способные образовывать более или менее устойчивые комбинации и служить ориентирами для политических акторов. В качестве инструментов анализа этих комбинаций мы будем использовать понятия «идеи», «идеологии», «дискурсы», «идеологические предпочтения» и др. Основное внимание будет уделено вербально оформленным смыслам, поскольку их роль в политических коммуникациях остается определяющей.

Во-вторых, для характеристики связей и отношений между символическими формами, определяющими политические процессы, используется метафора «пространство», а не «спектр». Не отрицая значения «право-левой» шкалы для анализа политических различий, следует признать, что структура идеологических размежеваний гораздо сложнее и многообразнее. «Она определяется наличием множества не совпадающих друг с другом водоразделов, заданных различиями ценностно детерминированных подходов к решению социально-экономических и политических проблем, цивилизационной самоидентификации, оценке роли государства, коллективного прошлого, принципов нациестроительства и проч.» [6, с. 14-15]. Поэтому мы видим свою задачу не столько в «картографировании» идеологического спектра и описании изменений, происходивших на протяжении последних двадцати лет на европейском и евразийском пространстве, сколько в анализе тенденций, связанных с формированием и развитием альтернативных способов интерпретации социально-политической реальности и соотнесенных с ним дискурсивных практик.

Такой подход побуждает уделять особое внимание «производителям» политически значимых смыслов, в первую очередь представителям политического класса. Данная категория шире, нежели политическая элита, так как охватывает не только тех, кто принимает политические решения, но также широкий круг лиц, профессионально занимающихся теми или иными аспектами политики и оказывающих косвенное влияние на политический процесс. В производстве, распространении и конкуренции политически значимых идей и смыслов помимо лиц, принимающих решения, активно заняты журналисты, 
аналитики, политические консультанты, спичрайтеры, а также люди, изучающие политику. Последние, безусловно, составляют особую группу, поскольку производимые ими смыслы облечены в форму, восприятие которой требует специальной подготовки, и распространены преимущественно (хотя и не исключительно) в рамках ограниченной профессиональной среды.

Впрочем, каждый из сегментов политического класса специфичен, так как по-разному локализован по отношению к публике и власти. Если для политиков функция производства смыслов является производной от решения других задач - борьбы за власть, мобилизации поддержки, легитимации политического курса и проч., то для других представителей политических профессий именно она является основной. Наконец, политически значимые смыслы порождаются не только в контексте собственно политических дискуссий - они существуют в более широком культурном поле, приобретая соответствующую окраску в зависимости от контекста. Исходя из этого, объектами нашего внимания стали не только политики (прежде всего вовлеченные в программно-идеологическую деятельность партий), но и журналисты, а также «публичные интеллектуалы».

То, каким образом в трансформирующем обществе производятся, распространяются и конкурируют идеи, определяется не только свойствами участвующих в этих процессах акторов (их когнитивными и ценностными установками, мотивацией, профессиональными навыками и т. п.), но и складывающимися правилами, нормами, коллективно формируемыми стратегиями, т. е. институтами. Поэтому имеет смысл проследить основные векторы трансформации институтов публичной сферы на евразийском пространстве, определяющие изменения условий «идеологического производства». Публичная сфера рассматривается как социальное пространство, где в более или менее открытом режиме обсуждаются политические идеи и вопросы общей значимости, формируется общественное мнение, конструируются и переопределяются коллективные идентичности. Публичная форма локализована в различных институтах и сочетает разные формы общения: как «живые», так и опосредованные письменными текстами. Она конституируется множеством частично пересекающихся «публик», границы которых меняются во времени, пространстве, а также в зависимости от характера обсуждаемых тем. Объем публичной сферы зависит как от меры дозволенного государством, так и от 
циклических колебаний интереса к общественным проблемам. «В качестве критериев для оценки состояния и изменения публичной сферы могут выступать: степень автономии публичной сферы от официальной и частной сфер, ее открытость для разных сегментов общества, ее фрагментированность, структура каналов коммуникации (сочетание “живого" обсуждения и общения посредством печатных и электронных текстов, особенности циркуляции последних) и др.» [7, c. 16].

Место Беларуси, России, Казахстана и Армении в русле евразийских интеграционных процессов нас интересует как дискурс идейносимволического пространства. Новейшие исследования показывают, что идейно-символическое пространство политики представляет собой многомерное, реально-политическое и ценностно-смысловое измерение [9, с. 15-17; 4].

Соглашаясь с подобными оценками, в анализе дискурса идейносимволического пространства политики в системе европейской интеграции мы будем учитывать не только изменения среды, в которой эти идеи и смыслы производятся, распространяются и соперничают друг с другом, но и конфигурации политических идей и символов во взаимосвязи с институциональными и дискурсивными условиями, определяющими правила игры и стратегии акторов, которые эти идеи и смыслы производят, и с политическими коммуникациями, обеспечивающими обращения последних.

Идейно-символическое пространство является одним из важнейших элементов, влияющих на процессы интеграции на постсоветском континенте. Значимость этого фактора сегодня возрастает и, возможно, будет возрастать и далее в связи с развитием «информационного общества» и изменением конфигурации властных отношений. Следует рассматривать возможность формирования общего идейносимволического пространства Беларуси, России, Казахстана и Армении как вполне реальную. Идейно-символическое пространство является духовно-практическим образованием, представляющим собой систему идей, поддерживаемых актором региональной политики, имеющих непосредственно деятельно-установочное значение и идеологический механизм (механизм внедрения этих идей в общественное сознание).

Оно является неотъемлемым свойством любой интегрированной общности и любого актора мировой и региональной политики и 
обеспечивает существование любого государственно-организованного общества как целостного образования.

Общее идейно-символическое пространство включает в себя взаимодействие мировоззренческих, ценностно-смысловых и социокультурных установок и практик. Его общность есть качественная характеристика, так как указанное взаимодействие смыслов и практик рождает общие преимущества и общие проблемы. В процессе такого взаимодействия происходит содержательная унификация идейносимволического пространства. При этом также не исключены конфликты интерпретаций, однако при разумно организованном идеологическом пространстве они могут быть преодолены через открытый дискурс.

Общее идейно-символическое пространство в системе евразийской интеграции - это коммуникативная ценностно-идейная среда, которая определяется характером взаимосвязи политико-правовой идеологии Беларуси, России, Казахстана и Армении как независимых международных акторов. В общее идеологическое пространство входят базовые ценности стран евразийской интеграции и связанные с ними политико-правовые и социокультурные практики [8, с. 102-114; 2, с. 36-37].

Дискурс-анализ положений Договора о Евразийском экономическом союзе (ЕАЭС) показывает, что в нем отсутствуют отсылки к общим (евразийским) ценностям.

Учитывая, что евразийские партнеры, исходя из оценки особенностей нынешнего этапа интеграции, не включили в договор политические аспекты, идейно-символический аспект не получил в нем достаточной проработки.

Однако в ст. 3 Договора о ЕАЭС перечисляется ряд принципов, на основе которых ЕАЭС должен осуществлять свою деятельность:

- уважение общепризнанных принципов международного права, включая принципы суверенного равенства государств-членов и их территориальной целостности;

- уважение особенностей политического устройства государствчленов;

- обеспечение взаимовыгодного сотрудничества, равноправия и учета национальных интересов государств-членов;

- соблюдение принципов рыночной экономики и добросовестной конкуренции; 
- функционирование таможенного союза без изъятий и ограничений после окончания переходных периодов [3].

В итоге можно констатировать, что в данном соглашении доминируют экономические приоритеты, нацеленные на обеспечение национальных интересов стран евразийской интеграции. Договор фиксирует переходный этап с перспективой движения к политической интеграции. Это, как следствие, потребует от акторов евразийского объединения определить свое отношение к общим ценностям. Но уже сегодня практика евразийских интеграционных процессов ставит вопрос, какие ресурсы и механизмы могут способствовать решению проблем и достижению желаемых интеграционных целей. Один из таковых ресурсов, по нашему мнению, - идейно-символический.

Основу этого ресурса составляет принцип, в соответствии с которым центр принятия решений по всем жизненно важным вопросам, относящимся к той или иной общности, должен находиться внутри соответствующих стран, а не в западных центрах. Из утверждения этого принципа закономерным образом вытекает, что решение общих проблем, выходящих за рамки компетенции и возможностей отдельных государств, должно достигаться в результате многостороннего, в том числе идейно-символического, диалога, с учетом интересов всех заинтересованных сторон. Диалог как определенный способ взаимодействия возможен лишь в том случае, если в ходе взаимодействия происходит сближение смыслов, утверждаемых той или иной цивилизационной традицией. Именно это мы имеем возможность наблюдать (несмотря на многочисленные реальные трудности, возникающие в ходе диалога) в странах евразийской интеграции. Ориентация участников объединения на формирование полицентрической структуры организации международного сообщества означает и глубокое изменение самой направленности процесса мирового развития, а именно изменение соотношения эндогенных (т. е. обусловленных внутренней логикой бытия той или иной цивилизации) и экзогенных (т. е. внешних по отношению к той или иной конкретной общности) факторов эволюции: усиление значения первых и, соответственно, уменьшение силы воздействия вторых.

В основе духовно-ценностной стратегии евразийской интеграции лежит общая ориентация на усиление значения эндогенных и уменьшение влияния экзогенных факторов развития. Совпадение позиций по этому пункту, судя по всему, имеет для участников объеди- 
нения большее значение, чем очевидные различия экономических и политических систем и существующие противоречия между ними.

Из охарактеризованной общей ориентации вытекает и та акцентировка роли национального государства (в противовес распространенным на Западе версиям о «затухании» этого института), которая, несомненно, объединяет всех участников евразийской интеграции. Именно такое государство является основным субъектом и институциональным рычагом осуществления тех преобразований (в том числе в сфере международных отношений), к которым они стремятся. В конце концов, в институциональном плане евразийская интеграция не что иное, как объединение именно национальных государств. Таким же образом из охарактеризованной общей установки вытекают и преимущественная ориентация на реальную, а не на «сервисную» (финансовую) экономику и особое внимание, уделяемое развитию внутреннего рынка.

Регионализация как одна из объединительных тенденций означает ориентацию на создание полицентричной структуры управления мировой системой связей, т. е. это альтернативный глобализации способ организации данной системы в условиях интенсификации и «уплотнения» таких связей. В этих условиях утвердить собственную неповторимую индивидуальность перед лицом нивелирующих тенденций мирового развития может лишь тот народ, та культура, которые смогли объединиться с другими, родственными или в чем-то близкими им народами и культурами. В этом контексте императив достижения взаимопонимания различных страновых духовно-ценностных традиций приобретает особое значение.

Общее понимание характера и задач процесса модернизации является следующей важнейшей чертой, объединяющей государства евразийской интеграции и одновременно отделяющей их от «коллективного Запада». В научной среде достаточно давно преобладает стремление к преодолению евроцентризма, однако на уровне официального идеологического и политического дискурса Запад склонен считать свою модель модернизации оптимальной и в связи с этим универсально значимой, а потому и «обязательной к исполнению» для всех, кто стремится идти в ногу со временем. Все без исключения участники евразийской интеграции на первый план выдвигают идею органического синтеза ценностей модернизации и собственной цивилизационной традиции. По нашему убеждению, есть все основания 
говорить о том, что эта идея лежит в основе их общей интеграционной стратегии.

Формирование общей идентификационной стратегии оказалось возможным в силу того, что при всей разнице традиций участников евразийской интеграции в самой глубинной основе их цивилизационного строя лежит нечто общее, некий общий комплекс ценностей, потенциально совпадающих по своей основной исторической направленности с ценностями модернизации.

Теоретическо-методологический анализ идейно-символической коммуникации в странах евразийской интеграции создает возможность для выявления тех типологических признаков интеграции, которые могут стать модельными в изучении многообразного содержания евразийской интеграции.

Для выявления этих признаков за основу мы взяли признак «образа действия»; под ним понимается специфический для данной интеграционной группировки набор алгоритмов реализации программы взаимодействия группы государств в конкретной сфере. «Образы действия» полезны для сравнительного анализа, поскольку они воплощают реальные черты сущностного, содержательного поведения стран - участниц интеграционных процессов, не привязываясь к конкретным формам этих действий [1, с. 9-10].

Для целей сравнения важно выделять образы действия в следующих основных областях интеграционных взаимодействий: 1) учреждение группировки; 2) идеологическое обоснование сближения; 3) экономическое строительство; 4) управленческая активность; 5) стратегия расширения и 6) модель обеспечения безопасности.

Исходной методологической гипотезой сравнительной аналитики стало предположение о том, что ключевое типологическое подобие интеграции в государствах евразийской интеграции определяется не процедурой принятия интеграционных решений или мерой реализованности принципа наднациональности, а устойчивой ориентацией участников интеграции на приоритетность развития внутригрупповых связей по отношению к внегрупповым, готовностью ради этого предоставлять друг другу на взаимной основе особые права, льготы и привилегии, а также явно выраженной волей к многостороннему сотрудничеству для решения общих проблем, подтверждаемой регулярностью встреч для решения вопросов, выходящих за рамки обычного международного общения. 


\section{Таблица. Параметры сравнительного анализа интеграционных объединений}

\begin{tabular}{|c|c|}
\hline Образ действия & Объект рассмотрения \\
\hline Учреждение группировки & Исходные мотивы сближения \\
\hline $\begin{array}{l}\text { Идеологическое обосно- } \\
\text { вание сближения }\end{array}$ & Обоснования сближения \\
\hline $\begin{array}{l}\text { Экономическое строи- } \\
\text { тельство }\end{array}$ & Цели и пределы экономического сращивания \\
\hline $\begin{array}{l}\text { Управленческая актив- } \\
\text { ность }\end{array}$ & $\begin{array}{l}\text { Соотношение полномочий руководящих органов, пропорция } \\
\text { элементов надгосударственного и межправительственного } \\
\text { управления }\end{array}$ \\
\hline Стратегия расширения & Подход к выбору критериев и темпов расширения \\
\hline $\begin{array}{l}\text { Модель обеспечения } \\
\text { безопасности }\end{array}$ & $\begin{array}{l}\text { Алгоритм обеспечения региональной безопасности: связан ли } \\
\text { институционально механизм безопасности с основными струк- } \\
\text { турами группировки }\end{array}$ \\
\hline
\end{tabular}

В духе такого понимания интеграции (и для получения аналитически полезных результатов) сравнению должны подлежать не столько формы воплощения интеграционных устремлений, сколько сами эти устремления, мера их устойчивости, направленность и результативность. «Работающей» основой анализа региональных вариантов интеграции послужила предложенная выше таблица сопоставления «образов действия» участников интеграции в главных сферах сближения.

Изучение этих образов действия в соответствии с цепочкой «потребность - интерес - цель - образ действия - результат» предполагало исследование исходных причин возникновения интеграционных импульсов (внешней и внутренней среды процесса), их отражение в концептуальных документах отдельных стран, многосторонних инициативах и соглашениях, планах действий на будущее, степени их реализации. В совокупности эти черты образуют «историко-политический тип» интеграции. 
Проведенное по такой схеме сравнение позволяет выявить черты существенного типологического сходства в развитии интеграционных процессов в ЕАЭС.

Сходство прослеживается прежде всего в содержании мотивационного комплекса в обоих ареалах, в структуре которого важную роль играла боязнь внутрирегиональных конфликтов, необходимость объединения перед лицом более крупных, в первую очередь внерегиональных, игроков.

В сфере идеологического обоснования интеграционных процессов наблюдается общность в усилиях по созданию символов общей идентичности, основанных на политических мифах об общности историко-культурного наследия, исторических и экономических судеб в будущем.

В экономике просматривается сходство в установке на упрощение условий внутрирегионального экономического обмена и создание условий для повышения конкурентоспособности интеграционной группы в целом по отношению к «сторонним» государствам. Вместе с тем обращают на себя внимание важные типологические различия парадигм экономической интеграции.

Для стран ЕАЭС характерны асинхронность и многоуровневость экономической интеграции, проявляющиеся с разной степенью глубины и интенсивности на нескольких уровнях. В минувшие полвека на пространстве этих государств наблюдались в сущности однородные модели расширения интеграционных «ядер». При кажущемся очевидном внешнем различии динамики интеграционных процессов в обоих этих регионах интеграционные импульсы тяготеют не к сплошному, а к очаговому типу распространения.

Понятие интеграции так или иначе связано с представлением о социально-политической гомогенности. Однако характер этой связи на пространстве обозначенных интеграций не прояснен. Можно предположить, что политическая однородность - одно из ключевых условий успешной интеграции. Но допустима и иная гипотеза: формирование политической однородности - не начальная точка интеграции, а один из ее возможных (не обязательно главных) результатов.

Экономическая политика большинства стран «интеграционного ядра» регионов неодинакова, но однородна. Это политика рыночного регулирования с более или менее заметной долей государственного контроля. Похоже, что отправной точкой данной версии интеграции 
является не политическое родство, а однотипность экономических политик.

В ЕАЭС процесс сближения идет с «переменной» скоростью. Интеграционный процесс здесь, по сравнению с европейским регионом, характеризуется выжидательностью, осмотрительностью. Случаются откаты интеграционных тенденций, однако в силу исходно низкой скорости интеграционного движения они не становятся губительными кризисами.

В указанных регионах интеграционное сближение происходит в большем соответствии с региональной конкретикой - мерой готовности или неготовности местных стран сближаться друг с другом, не конфликтуя.

Для евразийской интеграции характерен акцент на преобладании межправительственного подхода к принятию главных решений, в рамках которого ведущую роль играют не наднациональные институты, а исполнительная власть стран-членов. Сама мысль о делегировании власти «своего» правительства какому-то наднациональному органу не получает поддержки. Идеалом же выступает дозированная интеграция в экономике под строгим контролем суверенных национальных правительств.

Идейно-символическое сопровождение евразийской интеграции может осуществляться по разным направлениям и в разных формах. Одним из его приоритетных направлений является трансграничное и приграничное сотрудничество.

Трансграничное и приграничное сотрудничество можно классифицировать по двум направлениям - генерализированного (нормативно-упорядоченного) и негенерализированного (стихийно развивающегося) сотрудничества. В качестве матрицы сошлемся на опыт приграничных отношений ЕС и России. Данная матрица создана российскими исследователями Р. Х. Симоняном и Т. М. Кочегаровой [10, c. 46-48].

Современные модели и механизмы генерализированного приграничного взаимодействия ориентированы преимущественно на торгово-экономические отношения между соседними государствами. Эти модели могут действовать в соответствии с эффективными интеграционными схемами, сплачивающими сообщества приграничья, в том числе с помощью механизмов свободной торговли, а также таможенных, валютных, социально-экономических объединений. В со- 
ответствии с этим выделяют три модели генерализированного приграничного сотрудничества между Беларусью и Россией.

Первая - традиционная. В ее основе лежит существенная разница цен на товары и услуги по обе стороны границы, а экономический эффект связан с расширением рынка сбыта для одной стороны и получением более дешевых товаров и услуг для другой. Вторая преференциальная, предполагающая предоставление преференций приграничным регионам, как на двусторонней, так и на односторонней основе.

Эффективность этих моделей в значительной мере зависит от правил пограничного, миграционного и таможенного контроля, тарифных ограничений, налогообложения экспортируемых и импортируемых товаров, или, иными словами, от уровня либерализации трансграничного движения. Третья - институциональная, которая базируется на договорных отношениях, совместных проектах и программах, а также специально создаваемых организациях. Эффективность этой модели зависит от уровня децентрализации власти и государственных финансов, развития гражданского общества.

Одно из ключевых условий реализации этих моделей приграничного сотрудничества - эффективное функционирование рынка труда, который представляет собой механизм саморегулирования сферы оплачиваемой занятости на основе взаимодействия работодателей и нанимаемых работников, формирующего объем, структуру и динамику спроса на трудовые услуги и предложения рабочих мест.

Для генерализированного процесса приграничного взаимодействия характерно широкое участие органов власти субъектов местного самоуправления Беларуси на основе договоров с аналогичными территориальными органами власти России. Сферой сотрудничества являются не только транспорт, торговля, экология, информация, новые технологии, но и образование, культура. Генерализированное сотрудничество реализуется в рамках совместно или согласованно разрабатываемых программ и проектов.

В негенерализированном процессе можно выделить ряд форм приобщения одного народа к социокультурным ценностям другого в их непосредственном взаимодействии, которое описывается несколькими типологическими моделями.

Первая - аккультурационная. Ее характерная особенность - акцент на сознательном, добровольном, активном усвоении индивидом 
новой культуры. Здесь особая роль отводится фактору доверия. Характерными чертами этой модели являются: установка на взаимодействие, погружение в новую культурную среду; приобретение новых личностных контактов, связей, открывающих простор воображению человека. Реализация этой модели состоит из трех этапов: первый взаимосвязь предварительного образа с реальным и вытеснение предварительного; второй - персонализация - осознание характера нового социума через конкретных его представителей. И, наконец, третий этап - институционализация - поворот в сознании к более безличному, деперсонифицированному представлению о стране. Аккультурационная модель носит универсальный характер, так как в той или иной мере присутствует во многих типах социокультурного взаимодействия.

Вторая - кооперационная, раскрывающая возможности взаимовыгодного сотрудничества в различных сферах деятельности: индивидуальное или частное предпринимательство (в том числе совместный бизнес, приглашение иностранных специалистов), совместные научные исследовательские проекты, культурный и спортивный обмен, изучение опыта управления и т. д. Рост экономического сотрудничества способствует распространению национального языка, который становится все более ценным товаром на рынке труда.

Третья - познавательная. Эта модель реализует одну из основных потребностей личности и рассматривается как целенаправленный процесс познания иной культуры, иного социума. Присутствие в этом процессе имплицитного сравнения со своей культурой, социумом есть необходимый элемент их взаимодействия. Индивидуальный или групповой туризм является одной из наиболее распространенных форм этой модели.

Четвертая - образовательная. Одна из особенностей этой модели состоит в том, что при избрании жизненного пути выбор места приобретения профессиональных знаний часто оказывается определяющим. Вторая особенность заключается в императиве, так как решающим оказывается мотив целеполагания - получение образования. Вступление Беларуси в евразийское пространство высшего образования позволяет наполнить данную модель конкретным содержанием.

Пятая - ролевой тренинг. Еще одна сравнительно недавно возникшая модель социокультурного взаимодействия, в которой процесс взаимодействия, взаимопроникновения культур происходит как увле- 
кательный досуг, как ролевая модификация, как некий интеллектуально-приключенческий экстрим, потребность в котором возрастает в связи с ростом свободного времени и свободных денег. Ее побочный, но важный для процесса межкультурного взаимодействия продукт публикации в форме очерка, прежде всего в интернете, о личных впечатлениях, рождающихся в контакте с иной культурой. Эта модель является своеобразным актом самоутверждения. Здесь проявляется креативный, эвристический аспект взаимодействия. Данная модель описывает механизм вовлеченности в процесс усвоения новых социокультурных норм, возникший как элитарный, статистически пока еще не очень значимый, становящийся все более распространенным.

Шестая - потребительская. Шопинг - наиболее массовая, хотя и узкоспециализированная форма приобщения индивида к чужой культуре. Это явление возникло в Беларуси в конце 1980-х - начале 1990х гг. в связи с товарным голодом на потребительском рынке. Так называемый челночный бизнес вовлек в этот специфический вид социокультурного взаимодействия сотни белорусских граждан (включая интеллигенцию). Предельный прагматизм этой формы межкультурного обмена компенсируется ее масштабом. Через сферу экономических отношений эта форма породила новый вид мотивации для развития социокультурного взаимодействия. Связи, основанные на потреблении, вполне сопоставимы по значению с другими факторами взаимодействия культур.

Седьмая - миграционная. Масштабы переселения народов быстро возрастают, что трактуется как «миграционный бум». Для трансграничного сотрудничества Беларуси и России данную модель можно рассматривать как фрагментарную, точечную.

\section{Библиографические ссылки}

1. Байков $A$. А. Сравнительная интеграция : практика и модели интеграции в зарубежной Европе и Тихоокеанской Азии / отв. ред. А. Д. Богатуров. - М. : Аспект Пресс, 2012.

2. Барабанов О. Н., Клименко А. И. Перспективы формирования идеологического пространства России и Европейского союза / Моск. гос. ин-т междунар. отношений (ун-т) МИД России, каф. политики и функционирования Европейского союза и Совета Европы. - М. : МГИМО-Университет, 2010. - С. 36-37.

3. Договор ЕАЭС [Электронный ресурс]. - URL : http://economy.gov.ru/minec/about/structure/ depSNG/agreement-eurasian-econimic-union. (дата обращения : 16.01.2015). 
4. Идейно-символическое пространство постсоветской России : динамика, институциональная среда, акторы / под ред. О. Ю. Малиновой. - М. : РОССПЭН, 2013.

5. Идейно-символическое пространство постсоветской России : динамика, институциональная среда, акторы / под ред. О. Ю. Малиновой. - М. : РОССПЭН, 2013. - С. 14.

6. Идейно-символическое пространство постсоветской России : динамика, институциональная среда, акторы / под ред. О. Ю. Малиновой. - М. : РОССПЭН, 2013. - С. 14-15.

7. Идейно-символическое пространство постсоветской России : динамика, институциональная среда, акторы / под ред. О. Ю. Малиновой. - М. : РОССПЭН, 2013. - С. 16.

8. Лукин A. В. Столкновение ценностей в современном мире и перспективы евразийской интеграции // Полис. - 2014. - № 6. - С. 102-114.

9. Малинова О. Ю. Конструирование представлений о прошлом как властный ресурс // Символическая политика : сб. науч. тр. / отв. ред. О. Ю. Малинова. - М. : РАН ИНИОН, 2013. Вып. 1. - С. 15-17.

10. Симонян P. Х., Кочегарова T. М. Приграничное взаимодействие России и Евросоюза : тенденции и моделирование / Полис. - 2014. - № 5. - С. 42-49.

11. Bauman Z. In search of Politics. - Stanford : Stanford University Press, 1999. - P. 1-7; Freeden M. Political Ideology at Cenutry's End. - P. 9-14; Simons J. Ideology, Imagology, and Critical Thought : The Improverishment of Politics // J. of political ideologies. - 2000. - № 1. Vol. 5. - P. 81-103; Соловьев А. И. Политическая идеология : логика исторической эволюции // Полис. 2001. - № 2. - С. 5-23; Он же. Доклад на семинаре «Современные тенденции развития символического пространства политики и концепт идеологии» // Полис. - 2004. - № 4. - С. 28 36.

12. Согласно формулировке британского социолога Дж. Б. Томсона, «анализ идеологии должен ориентироваться не столько на светские системы убеждений, формулируемые и выражаемые организованными политическими группами, сколько на то, как различные символические феномены функционируют в социальном мире, пересекаясь с отношениями власти» (Thomson J. B. Ideology and Modern Culture. Critical Social Theory in the Era of Mass Communication. - Oxford, 1990. Р. 265). Подробнее о реинтерпритации концепта идеологии и возможности его использования для изучения символического пространства современной политики см.: Малинова О. Ю. Концепт идеологии в современных политических исследованиях // Полит. наука. - 2003. - № 4. - С. 8-31; Она же. Доклад на семинаре «Современные тенденции развития символического пространства политики и концепт идеологии» // Полис. - 2004. № 4. - С. 37-42. Вместе с тем есть и попытки реинтерпретировать понятие идеологии за счет сужения его содержания. Так, С. Хансон в своей недавней работе определяет идеологию как «ясное и последовательное определение критериев членства в желаемом политическом порядке», способное задавать ориентиры для политической самоидентификации и служить основой коллективного действия (Hanson S. Pos-Imperial Democracies. Ideology and Party Formation in Third Republic France, Weimar Germany, and Post-Soviet Russia Cambridge. - Cambridge University Press, 2010. - P. 46-47). По мнению Хансона, такой подход дает возможность для операционализации понятия, позволяющей прослеживать причинные эффекты идеологии.

\section{Идейно-символическое пространство политики в системе евра- зийской интеграции: теоретико-методологический дискурс иссле- дования (Виктор Ватыль)}

На основе дискурсивного изучения рассматривается структурнофункциональный вариант анализа идейно-символического простран- 
ства в системе евразийской интеграции, выявляются теоретико-методологические подходы и трактовки понятия «идейно-символическое пространство», дается характеристика места и роли идейно-символического пространства политики на современном этапе развития Евразийского экономического союза, определяется типология сравнительного анализа основных характеристик обозначенного дискурса.

\section{Ключевые слова}

Евразийская интеграция; идейно-символическое пространство политики; типология сравнительного анализа; модели трансграничного сотрудничества.

The ideological and symbolic space of policy in the system of the Eurasian integration: theoretical and methodological discourse of study (Victar Vatyl)

On the basis of discursive study structural-functional version of the analysis of ideological and symbolic space in the system of the Eurasian integration is explored, theoretical and methodological approaches and interpretations of the concept of «ideological and symbolic space» are identified, the place and role of ideological and symbolic space policy at the present stage of development of the Eurasian Economic Union is described, a comparative analysis of the typology of comparative analysis of the main characteristics of the designated discourse is determined.

\section{Key words}

Euroasian integration; ideological and symbolical space of policy; typology of the comparative analysis; model of cross-border cooperation.

Статья поступила в мае 2015 г.

\section{Рецензенты:}

Решетников С. В. - доктор политических наук, профессор, заведующий кафедрой политологии Белорусского государственного университета;

Челядинский А. А. - доктор исторических наук, профессор кафедры международных отношений Белорусского государственного университета. 


\title{
ДЕЯТЕЛЬНОСТЬ КНР ПО РАЗВИТИЮ
}

\section{МЕЖДУНАРОДНОГО ТУРИЗМА НА СОВРЕМЕННОМ ЭТАПЕ}

\author{
Л. М. Гайдукевич \\ доктор исторических наук, дочент, \\ заведуюший кафедрой международного туризма \\ Белорусского государственного университета
}

\section{Гэ Инь}

магистр экономики

УДК $351: 338.48(510)$

Современные международные отношения предполагают использование различных инструментов «мягкой силы» во внешней политике. Развитие туризма и создание соответствующих условий является одним из таких инструментов.

В последние десятилетия туризм в Китае развивался стремительными темпами. Этому во многом способствовала политика китайского руководства, направленная на укрепление материального благосостояния среднего слоя населения и снятие ограничений на посещение Китая иностранцами.

Однако развитие туризма в Китае исследуется пока недостаточно. Необходимо выделить российских исследователей Ю. Александрову, П. Кожанова, Ю. Кужель. Из белорусских исследований следует отметить коллективные публикации кафедры международного туризма БГУ [18].

Несмотря на заметное место туризма в экономике страны, в китайском законодательстве до 2013 г. отсутствовал единый закон, регулирующий данную отрасль. Активная работа по регулированию и совершенствованию правовой системы туристической отрасли была проведена в годы реализации планов 10-й пятилетки (2000-2015 гг.).

Цель настоящей статьи - изучение национальных особенностей международного туризма в КНР на современносм этапе.

Государственное управление по делам туризма КНР - ГУДТ КНР (China National Tourism Administration - CNTA) - официально создано в 1964 г. Это орган государственной власти, ответственный за развитие туризма в стране. Управление находится в непосредственном подчинении Государственного совета КНР, его штаб-квартира располо- 
жена в Пекине, а региональные отделения (бюро) - в китайских провинциях, которые подотчетны в своей деятельности ГУДТ КНР. В структуре ГУДТ КНР работает семь департаментов.

ГУДТ КНР имеет 16 зарубежных представительств (Китайские национальные бюро по туризму - China National Tourism Offices), ocновная задача которых - популяризация китайского туризма и привлечение иностранных туристов в Китай. Офисы зарубежных представительств расположены в 13 важнейших с точки зрения туризма странах и регионах. Например, в Европе действуют офисы в Москве, Лондоне, Париже, Франкфурте, Цюрихе.

В 2000-2015 гг. Государственным управлением по делам туризма КНР совместно с рядом заинтересованных ведомств был разработан ряд документов по стандартизации и совершенствованию управления туризмом в стране.

В частности, в целях совершенствования управления отраслью ГУДТ КНР в 2000 г. издало «Управленческие методы планирования развития туризма» и «Временные методы установления подлинности объектов для планирования туристической деятельности» [1;2]. В 2001 г. пересмотрены и дополнены новыми статьями, подразделяющими туристические агентства на международные и внутренние, Положения об управлении туристическими агентствами от 1996 г. Отдельная глава была посвящена турагентствам, созданным с участием иностранного капитала [12].

В «Уведомлении о дальнейшем ускорении работы по оценке рейтинга гостиниц» и «Временных методах по управлению работой по созданию основных китайских туристических городов» был разработан инструментарий оценки классов гостиниц на основании их рейтинга (с присвоением им определенного количества «звезд»), а также определены основные туристические города (top tourist cities) [16; 4].

Представляет интерес разработанный в рамках 11-й пятилетки План развития туристической отрасли Пекина, принятый в 2006 г. Документ предусматривал использование всех возможностей развития инфраструктуры, информационных технологий, национальной кухни, сувенирной продукции, связанных с проведением летних Олимпийских игр 2008 г. в Пекине [8].

В январе 2010 г. ГУДТ КНР издало два документа по учреждению постоянных представительств иностранных туристических агентств: «Временные административные положения об учреждении 
в КНР постоянных представительств иностранными правительственными туристическими организациями» и «Положение о создании в Китае туристических постоянных представительств иностранными предприятиями», которые раскрывают принципы деятельности постоянных представительств иностранных туристических агентств в стране $[3 ; 10]$.

Следует отметить, что в настоящее время акцент в нормотворческой деятельности в области туризма смещен на провинциальный уровень. Региональные отделения ГУДТ и местные власти КНР в рамках своей компетенции принимают нормативные акты, направленные на регулирование туристической деятельности в провинциях и муниципальных образованиях.

Закон КНР «О туризме» принят 25 апреля 2013 г. и вступил в силу 1 октября 2013 г. Он регулирует вопросы ведения туристской деятельности в КНР, заключения договоров об оказании туристских услуг, обеспечения безопасности туристов, государственного контроля в сфере туризма, разрешения споров и юридической ответственности туристических компаний (туроператоров) [6]. 2 сентября 2013 г. Государственное управление по делам туризма КНР опубликовало уведомление «О применении некоторых положений Закона КНР «О туризме» (далее - Уведомление № 280-2013) [15]. В соответствии с данным документом устанавливается приоритет закона над остальными нормативно-правовыми актами.

До принятия Закона «О туризме» туристская деятельность в КНР регулировалась подзаконными нормативно-правовыми актами. Среди них стоит выделить положение «О туристических обществах» (правила создания туристических компаний и регулирования их деятельности), «Временные правила управления приграничным туризмом» (регулирование туристических поездок в приграничных регионах), «Правила управления зарубежных туристических поездок граждан Китая» (регулирование выездного туризма) [9; 5]. С 1 октября 2013 г. все ранее принятые подзаконные акты применяются только в той части, в которой они не противоречат Закону «О туризме».

Государственное управление по делам туризма КНР уведомило, что закон обладает высшей юридической силой по сравнению с остальными подзаконными актами (административными правовыми актами, актами министерств и ведомств Государственного совета КНР и местным законодательством). В случае расхождения положений под- 
законных актов с положениями Закона «О туризме», должны применяться положения закона.

Управления по делам туризма на местах в срок до шести месяцев были обязаны в пределах своих полномочий внести изменения в подзаконные акты или выдвинуть предложения по внесению изменений в соответствующие органы для того, чтобы привести содержание подзаконных актов в соответствие с Законом «О туризме». В случае расхождения положений об административной ответственности (видах, размерах и пределах применения наказаний за правонарушения) в действующих подзаконных актах с положениями Закона «О туризме» управления по делам туризма с 1 октября 2013 г. обязаны применять административные наказания в соответствии с Законом «О туризме» $[6]$.

В статье 28 Закона прописаны требования по созданию туристической компании, включающие:

- постоянное место ведения хозяйственной деятельности;

- необходимое оборудование для ведения деятельности;

- отвечающую требованиям сумму уставного капитала;

- необходимое количество сотрудников и гидов;

- соответствие другим требованиям, предусмотренным законом и административными правовыми актами [6].

Закон КНР «О туризме» не раскрывает данные предписания. Нормативно-правовые акты требуют, чтобы минимальный уставный капитал туристической компании составлял 48 тыс. долларов (ст. 6 положения «О туристических обществах»).

Постоянное место ведения деятельности означает, что туристическая компания не может быть зарегистрирована без адреса или с виртуальным офисом [9]. Требование о «необходимом количестве сотрудников и гидов» в подзаконных актах не раскрывается [6].

Уведомление № 280-2013 [15] уточняет, что необходимые сотрудники - это управляющие (менеджеры) и сотрудники, ответственные за общее руководство приемом и отправкой туристических групп. Они должны иметь опыт работы в сфере туризма не менее одного года или схожий профессиональный опыт.

Этим же документом устанавливается необходимое количество гидов - не менее 20 \% штата туристической компании. В любой туристической компании должно быть не менее трех гидов, имеющих со- 
ответствующие удостоверения и заключивших с туристической компанией трудовой договор [6].

С 1 октября 2013 г. при создании туристических компаний требования о необходимом количестве гидов, наличии менеджеров по приему и отправке туристических групп обязательны. Если заявитель не может подтвердить наличие у него необходимых сотрудников, в регистрации туристической компании будет отказано.

В Законе «О туризме» предусмотрены гарантии качества туристических услуг. В соответствии со ст. 31 туристические компании обязаны вносить сумму гарантии качества услуг, которая может быть использована для выплаты возмещения вреда, причиненного правам и интересам туристов, или оплаты расходов при возникновении опасности причинения вреда жизни и здоровью туристов [6, с. 14]. Закон КНР «О туризме» не содержит правил использования гарантийной суммы. Касательно возмещения вреда, причиненного правам и интересам туристов, действуют ранее принятые правила, содержащиеся в положении «О туристических обществах» [9].

В соответствии со статьей 15 положения управление по делам туризма вправе использовать гарантийную сумму туристической компании для:

- выплат в счет возмещения туристам, правам и интересам которых был причинен ущерб в результате нарушения туристической компанией договора об оказании туристских услуг (если факт причинения ущерба проверен и признан управлением по делам туризма);

- выплат в счет возмещения убытков туристам, оплатившим туры, но не получившим соответствующих услуг в связи с ликвидацией, банкротством туристических компаний или по другим причинам.

Кроме того, из гарантийной суммы может выплачиваться компенсация по решению народного суда, если туристическая компания отказывается (или не имеет возможности) исполнить вступившее в законную силу решение, определение суда или другой судебный акт, признающий факт нарушения прав и законных интересов туриста и обязывающий туристическую компанию возместить причиненный туристу ущерб [6].

Использование гарантийной суммы для оплаты расходов при возникновении опасности причинения вреда жизни и здоровью туристов уточнено Уведомлением № 280-2013. При возникновении такой 
опасности туристическая компания, не имеющая возможности оплатить экстренные расходы, обязана обратиться в управление по делам туризма. Туристическая компания может использовать гарантийную сумму для оплаты экстренных расходов. Допускается использование гарантийной суммы для оплаты экстренных расходов по решению управления по делам туризма, если туристическая компания отказывается от оплаты данных расходов [15].

Статья 37 Закона «О туризме» предусматривает порядок получения удостоверения гида - его может получить физическое лицо, успешно прошедшее экзамен для гидов и заключившее трудовой договор с туристической компанией либо зарегистрированное в соответствующей отраслевой организации [6].

Государственное управление по делам туризма КНР уточняет, что экзамен для гидов проводится по ранее утвержденным правилам, а под заключением трудового договора с туристической компанией понимается заключение срочного или бессрочного трудового договора.

В случае если за получением удостоверения гида обращается лицо, успешно сдавшее экзамен, но не имеющее трудового договора с туристической компанией, оно обязано зарегистрироваться в отраслевой туристической организации - отделении туристических гидов, другом отделении, созданном при местной ассоциации туристических операторов, или местной ассоциации туристических гидов, созданной на уровне города с районным делением или выше. Получить удостоверение руководителя туристической группы могут лица, имеющие удостоверение гида, соответствующее образование, опыт работы в туристической отрасли от трех лет и трудовой договор, заключенный с туристической компанией. Необходимо также знание языков [6].

Уведомление № 280-2013 уточняет, что соответствующее образование - это образование не ниже среднего специального и знание языка государства (территории) - места назначения туристической группы, выезжающей за рубеж. Опыт работы в туристической отрасли не менее двух лет работы на соответствующих должностях в туристической компании [15]. Сотрудники туристических компаний, имеющие удостоверения руководителя туристической группы, но не соответствующие данным требованиям, должны восполнить пробелы до 1 октября 2016 г. Это достаточный срок для приобретения необходимого опыта работы, получения среднего специального образования, изучения основ избранного иностранного языка [14]. 
12 мая 2013 г. Государственное управление по делам туризма КНР опубликовало «Правила применения административных наказаний за правонарушения в сфере туризма» (далее - Правила).

Правилами предусмотрены следующие административные наказания за правонарушения в сфере туризма:

- предупреждение;

- административный штраф;

- конфискация незаконно полученного дохода;

- приостановление или аннулирование лицензии на оказание услуг выездного туризма;

- предписание по проведению упорядочивания деятельности;

- изъятие или аннулирование удостоверений гида или руководителя туристической группы;

- аннулирование лицензии туристической компании;

- другие виды административных наказаний, предусмотренные законами и административными правовыми актами [13].

Контроль за соблюдением законодательства в сфере туристской деятельности осуществляют органы Государственного управления по делам туризма, торгово-промышленной администрации, контроля качества, инспекции и карантина, Министерства транспорта и др. На органы Государственного управления по делам туризма возлагаются обязанности по координации действий всех контролируемых органов, организации совместных проверок и обмену информацией.

Вынесение решений и применение административных наказаний за правонарушения в сфере туризма осуществляются органами государственного управления в сфере туризма уездной ступени. По общему правилу решения принимаются органом по месту совершения правонарушения.

Если в ходе разбирательства о правонарушении выявлено, что правонарушение также допущено компанией, отправившей группу туристов, местный орган обязан передать материалы для проведения разбирательства по месту нахождения компании, отправившей туристов. В случае если правонарушение совершено за пределами КНР, то разбирательство проводится органом по месту нахождения туристической компании, отправившей группу туристов за рубеж.

Управления по делам туризма провинций, автономных районов, городов центрального подчинения проводят разбирательство по важ- 
нейшим и сложным правонарушениям, совершенным в пределах соответствующих административно-территориальных образований. Государственное управление по делам туризма КНР проводит разбирательство по делам, имеющим имиджевое значение для страны.

Административное наказание в виде аннулирования лицензии туристической компании (в том числе лицензии на право организации выездного туризма), удостоверения гида или руководителя туристической группы может быть наложено органом государственного управления в области туризма не ниже окружной ступени (города с районным делением, округа). Если в ходе разбирательства будут выявлены признаки преступления, органы государственного управления в сфере туризма обязаны передать документы органам юстиции [13].

Закон КНР «Об административном лицензировании» устанавливает общие правила административного лицензирования (правила введения лицензий; определение лицензирующих органов, процедура административного лицензирования, сборы за выдачу лицензий, юридическая ответственность). При выдаче отдельных лицензий применяются соответствующие подзаконные акты о порядке выдачи лицензий [7].

В соответствии с законом административное лицензирование может не применяться по отношению к гражданам и организациям, которые способны самостоятельно принимать решения, эффективно регулировать свою деятельность с использованием механизмов рыночной конкуренции и при помощи отраслевых ассоциаций [7].

При отсутствии нарушений в течение двух лет с момента получения лицензии туристическое агентство с участием иностранного капитала может подать заявление на получение права организации в стране выездного туризма [9].

Если в течение трех лет с момента перечисления или доплаты у туристического агентства не было административных взысканий и наказаний в связи с нарушением прав туристов, Государственное управление по туризму КНР вправе уменьшить гарантийную сумму турагентства в два раза.

Если организация ведет деятельность без соответствующей лицензии, орган государственного управления в сфере туризма или орган торгово-промышленной администрации издает предписание об устранении нарушений, конфискует незаконно полученный доход, а также налагает штраф в размере от 1600 до 16000 долларов [9]. 
Правила присвоения «звезд» гостиницам в Китае определены государственным стандартом GB/T14308-2010 «Классификация и оценка звездного уровня гостиниц», а порядок проверки и присвоения количества «звезд» установлен «Правилами применения государственного стандарта GB/T14308-2010» (Уведомление Государственного управления по делам туризма № 234-2010) [17].

В соответствии с государственным стандартом все отели разделены на пять категорий - от одно- до пятизвездочных (включая особую категорию - «платиновые пятизвездочные отели»). Оценка категории отелей проводится сначала по обязательным требованиям. Отели, отвечающие обязательным требованиям для отелей трех, четырех и пяти «звезд», дополнительно оцениваются по инфраструктуре и качеству управления отелем.

Соответствие отеля требованиям инфраструктуры оценивается по балльной системе с максимальным показателем в 600 баллов. Трехзвездочные отели должны набрать не менее 220 баллов, четырехзвездочные - не менее 320 , пятизвездочные - не менее 420 баллов. Самый значимый критерий в оценке - номер для гостей: на него приходится почти треть баллов за инфраструктуру отеля (191 балл). Расположение отеля оценивается в 30 баллов, наличие ресторана - в 59, обеспечение безопасности - в 16 баллов. Специальные требования к деловым отелям оцениваются в 70 баллов, а к отелям для отдыха - в 65 баллов [17].

Соответствие отеля требованиям по системе управления оценивается в процентах. Трехзвездочные отели должны набрать не менее $70 \%$, четырехзвездочные - не менее $80 \%$, пятизвездочные - не менее $85 \%$. Общее количество баллов, которые отели могут набрать за управление, -600 . Из них: система менеджмента - 60 баллов, качество услуг стойки обслуживания - 111, качество обслуживания номеров - 126 , качество обслуживания в ресторанах - 117 , остальные услуги - 84 балла, обслуживание мест общего пользования - 102 балла.

В первую очередь оценивается качество услуг отеля, начиная с ответа персонала на звонок на общий телефон и заканчивая отъездом гостя из отеля. Например, оценивается скорость ответа на звонок в отеле, вежливость сотрудников, знание ими цен, различий номеров отеля, способность ответить на английском языке, обслуживание гостей при въезде и выезде из отеля. Здесь же оценивается качество обстановки в номерах отеля и местах общего пользования [17]. 
Все новые отели могут обратиться за присвоением категории по истечении одного года с начала ведения хозяйственной деятельности. Уведомление Государственного комитета по делам туризма содержит только правила присвоения категории пятизвездочного отеля (при присвоении других категорий используются похожие правила). Заявление на присвоение отелю категории пятизвездочного подается в комитет по присвоению категорий по месту нахождения отеля. Комитет в течение одного месяца проводит проверку заявительных документов.

Если все документы отвечают требованиям, местный комитет направляет заявительные документы отеля в общенациональный комитет со своей рекомендацией. Общенациональный комитет организует проверку, которая может быть открытой или тайной. Если по результатам проверки отель не соответствует требованиям, его сотрудникам предлагается исправить все ошибки и снова обратиться с заявлением о проведении проверки. Решение об отказе может быть обжаловано в Государственный комитет по делам туризма КНР, за которым остается право принятия окончательного решения.

Общенациональный комитет по поручению Государственного комитета по делам туризма КНР регулярно проводит выборочную проверку отелей, которым присвоена звездная категория. В случае выявления несоответствия отеля требованиям Государственный комитет по делам туризма КНР вправе отменить решение о присвоении отелю категории. Решение о присвоении «звезд» действует три года. Затем проводится новая проверка отеля [17].

В настоящее время акцент в нормотворческой деятельности в области туризма смещен на провинциальный уровень и реализуется на основе положения о создании Государственного фонда развития малого и среднего предпринимательства. Фонд обеспечивает налоговые льготы и дополнительное финансирование для малого предпринимательства. Местные власти и региональные отделения ГУДТ КНР принимают нормативные акты, направленные на регулирование туристической деятельности в провинциях и муниципальных образованияХ [11].

Учитывая, что Китай - огромная по территории и населению страна со сложной трехуровневой системой управления (страна, провинция, город), инструменты государственного регулирования различаются по масштабу воздействия в соответствии с этими уровнями. 
На национальном уровне осуществляется поддержка внешнеэкономической деятельности субъектов малого предпринимательства. Ежегодно государство составляет программу по поддержке внешнеэкономической деятельности, которая оказывает помощь в организации и участии в международных совещаниях, семинарах, выставках и ярмарках, предоставляет информацию о рынке, помощь в поиске зарубежных партнеров. Государственное поощрение инноваций способствует внедрению новых технологий, ускорению онлайн-продаж, использованию современной научно-технической информационной сети, новых видов энергии, материалов, техники при производстве туристического продукта, а также активному содействию развитию «интеллектуальных» путешествий и «зеленого» туризма.

Таким образом, основным законодательным актом, регулирующим деятельность туристических организаций, является закон КНР «О туризме». Данный закон регулирует вопросы ведения туристской деятельности в КНР (заключения договоров об оказании туристских услуг, обеспечения безопасности туристов, государственного контроля в сфере туризма, разрешения споров, юридической ответственности туристических компаний). Проведенный анализ показывает, что закон «О туризме» дополнен нормативно-правовыми актами, расширяющими его влияние на местном уровне. Эти меры способствуют улучшению ведения туристического бизнеса в стране, поддержке малого и среднего бизнеса в туристической отрасли, эффективному использованию и охране туристических ресурсов в КНР.

\section{Библиографические ссылки}

1. CNTA No.12 Decree «Managerial Methods for Planning Tourism Development»// International tour management association [Электронный pecypc]. - URL : http://www.gjly.org.cn/english/ content_440.html (дата обращения : 10.03.2015).

2. CNTA No.13 Decree Temporary Methods for Qualification // International tour management association [Электронный ресурс]. - URL : http://www.gjly.org.cn/english/content_445.html (дата обращения : 10.03.2015).

3. Временные административные положения об учреждении в КНР постоянных представительств иностранными правительственными туристическими организациями // Гос. упр. делами туризма [Электронный ресурc]. - URL : http://www.cnta.gov.cn/html/2009-5/2009-5-27-845-10666.html (дата обращения : 10.03.2015).

4. Временные методы по управлению работой по созданию основных китайских туристиче- 
ских городов // Байду : энцикл. [Электронный ресурс]. - URL : http://baike.baidu.com/ view/438323htm (дата обращения : 10.03.2015).

5. Временные правила управления приграничным туризмом // Гос. упр. делами туризма [Электронный pecypc]. - URL : http://www.cnta.gov.cn/html/2010-12/2010-12-15-15-1344723.html (дата обращения : 11.03.2015).

6. Закон КНР «О туризме»// Гос. упр. делами туризма [Электронный ресурс]. - URL : http://www.cnta.gov.cn/html/fl/index.html (дата обращения : 11.03.2015).

7. Закон КНР «Об административном лицензировании» // Новости Синхуа [Электронный pecypc]. - URL : http://news.xinhuanet.com/zhengfu/2003-08/28/content_1048844.htm (дата обращения : 11.03.2015).

8. План развития туристической отрасли Пекина в рамках 11-й пятилетки // Окно Столицы [Электронный ресурс]. - URL : http://zhengwu.beijing.gov.cn/ghxx/sywgh/t833139.htm (дата обращения : 12.03.2015).

9. Положение «О туристических обществах» // Гос. упр. делами туризма [Электронный реcypc]. - URL : http://www.cnta.gov.cn/html/2009-2/2009-2-27-8-40-40562_1.html (дата обращения : 11.03.2015).

10. Положения о создании в Китае туристических постоянных представительств иностранными предприятиями // Гос. упр. делами туризма [Электронный ресурс]. - URL : http://www. cnta.gov.cn/html/2009-5/2009-5-27-8-45-10666_1.html (дата обращения : 12.03.2015).

11. Положение о создании «Государственного фонда развития малого и среднего предпринимательства» // Гос. упр. делами туризма [Электронный ресурс]. - URL : http://www.cnta.gov.cn/html/2009-6/2009-6-29-11-18-09780_1.htm.1 (дата обращения : 12.03.2015).

12. Положения «Об управлении туристическими агентствами» // Гос. упр. делами туризма [Электронный ресурс]. - URL : http://www.cnta.gov.cn/html/2009-2/2009-2-27-8-40-40562_1.html (дата обращения : 12.03.2015).

13. Правила применения административных наказаний за правонарушения в сфере туризма // Гос. упр. делами туризма [Электронный ресурс]. - URL : http://www.cnta.gov.cn/html/20135/2013-5-15-16-51-35215.html (дата обращения : 12.03.2015).

14. Разъяснение к Закону КНР «О туризме» // Блог о законодательстве Китая [Электронный pecypc]. - URL : http://cnlegal.ru/china_visa_tourism/tourism_law_implementation/ (дата обращения : 13.03.2015).

15. Уведомление «О применении некоторых положений Закона КНР о туризме» // Гос. упр. делами туризма [Электронный ресурс]. - URL : http://www.cnta.gov.cn/html/2013-9/2013-9-2\%7B@ hur\%7D-33-07646_1.html (дата обращения : 13.03.2015).

16. Уведомление о дальнейшем ускорении работы по оценке рейтинга гостиниц // Гос. упр. делами туризма [Электронный ресурс]. - URL : http://www.cnta.gov.cn/html/2011-11/2011-1129-15-21-86138.html (дата обращения : 13.03.2015).

17. Уведомление Государственного управления по делам туризма № 36 // Гос. упр. делами туризма [Электронный ресурс]. - URL : http://www.cnta.gov.cn/html/2011-4/2011-4-8-14-4148714.html (дата обращения : 14.03.2015).

18. География международного туризма. Зарубежные страны : учеб. пособие / Л. М. Гайдукевич [и др.]. - Минск : Аверсэв, 2003. 
Деятельность КНР по развитию международного туризма на современном этапе (Леонид Гайдукевич, Гэ Инь)

Китайская Народная Республика сегодня поражает темпами экономико-социального развития практически во всех сферах, в том числе в туризме. Страна ежегодно принимает около 130 млн туристов, а доход от туризма превышает 12 млрд долларов. Столь динамичное развитие туристского комплекса страны требует и соответствующего научного исследования. В статье не только рассматриваются современные тенденции и специфика развития туризма в Китае, но и исследуется его нормативно-правовая база, обеспечивающая эффективное регулирование туризма в стране.

\section{Ключевые слова}

Китай; международный туризм как «мягкая сила»; внешняя политика; туристская инфраструктура; гостиничный бизнес; туроператоры; турагенты; Закон «О туризме»; лицензирование; сертификация.

\section{The activities of China on development of international tourism at the present time (Gaydukevich Leonid, Ge Yin)}

Today, Peoples Republic of China amazes the world by the pace of economic and social development in almost all spheres, including in tourism. The country welcomes about 130 million tourists each year, and income from tourism is over 12 billion US dollars. Such a dynamic development of the tourism industry of the country requires appropriate scientific research. The article not only discusses current trends and features of tourism development in China, but also researches the regulatory framework that ensures effective regulation of tourism in the country.

\section{Key words}

China; international tourism as «soft power»; foreign policy; infrastructure of tourism; hotel industry; tour operators; travel agents; tourism law; licensing; certification.

Статья поступила в мае 2015 г.

\section{Рецензенты:}

Решетников С. В. - доктор политических наук, профессор, заведующий кафедрой политологии Белорусского государственного университета;

Челядинский А. А. - доктор исторических наук, профессор кафедры международных отношений Белорусского государственного университета. 


\section{МЕЖДУНАРОДНЫЕ АСПЕКТЫ ЭНЕРГЕТИЧЕСКОЙ \\ ПОЛИТИКИ ФРГ В НАЧАЛЕ ХХІ ВЕКА}

\section{E. В. Гартунг}

выпускница факультета международных отношений

Белорусского государственного университета

УДК 339.97:620.9(430)

Энергетика является одним из столпов, на которых строится экономика Федеративной Республики Германия. Это четвертая страна в мире по уровню ВВП, седьмая по уровню потребления первичной энергии и шестая по уровню потребления электроэнергии. При этом 63 \% потребляемой энергии страна получает извне, что говорит о высокой зависимости Германии от импорта энергоносителей.

В последние 15 лет ФРГ проводит активную политику в сфере энергетики. В начале третьего тысячелетия страна начала беспрецедентный ряд реформ, направленный на снижение зависимости от импорта.

Цель данной статьи - определение и анализ основных международных аспектов энергетической политики ФРГ в начале XXI в. Хронологические рамки исследования охватывают период с 1998 по начало 2015 г. Это обусловлено началом реализации масштабных реформ в сфере энергетики «красно-зеленой» коалицией, сформированной по итогам выборов в бундестаг 1998 г. Развитие внешней энергетической политики Германии рассматривается в связи со сменами правящих коалиций и изменением подходов к реализации энергетической политики ФРГ.

Следует отметить, что в современной историографии отсутствуют работы, которые всесторонне и детально рассматривают внешний вектор энергетической политики ФРГ. Некоторые публикации посвящены изучению внутренней энергетической политики Германии и не уделяют внимания ее международным аспектам. Другие работы рассматривают внешнюю энергетическую политику Германии, но только в рамках двустороннего взаимодействия с Россией. Еще одна группа работ исследует энергетическую политику ЕС, в том числе ее международную составляющую, однако позиция Германии в них не выделяется. Наиболее изученным направлением в совре- 
менной историографии является двустороннее энергетическое сотрудничество Германии и России.

Хронологические рамки работы охватывают период с 1998 по 2015 г. Более детально в историографии изучен период первой половины 2000-х гг. Однако монографии об актуальном состоянии внешней энергетической политики ФРГ отсутствуют.

Среди белорусских авторов вопросы энергетической политики затронули Л. М. Хухлындина в статье «Энергетическая политика Европейского союза в начале XXI в.», И. М. Махнач в статье «Развитие энергетического диалога Российской Федерации и Европейского союза», А. В. Шарапо в статье «Некоторые аспекты формирования электоральных настроений немецкого общества политическими партиями ФРГ», В. В. Фрольцов в монографии «Постсоветские государства во внешней политике ФРГ (1991-2005)». В этих работах внимание уделено вопросам газового сотрудничества и взаимозависимости Германии и России, вопросам атомной энергетики Германии.

Российские ученые также уделяют должное внимание внешней энергетической политике Германии. Следует отметить работу Н. В. Павлова «Внешняя политика “большой коалиции” 20052009 гг.», статью О. В. Витковского «Ядерная энергетика Германии: быть или не быть?», статью В. В. Евсеева «Влияние международной торговли ядерными материалами и технологиями на режим ядерного нераспространения», монографию В. Б. Белова «Германия. Вызовы XXI века». В них, как и в работах белорусских ученых, акцент сделан на рассмотрение сотрудничества в газовой и ядерной сферах.

Тема внешней энергетической политики Германии затрагивается во многих работах зарубежных авторов. Среди них публикации Ф. Умбаха «Внешняя политика и энергетическая безопасность Германии» и «На пути к европейской внешней энергетической политике?», статья Р. Гетца «Германо-российские энергетические отношения: по особому пути или по европейским следам?», работа М. Зандера «Стратегическое партнерство? Германская политика энергетической безопасности в рамках ЕС и значение России». Однако в них эта политика, как правило, лишь вскользь рассматривается в контексте общеевропейской энергетической политики.

Вся изученная историография в той или иной степени освещала некоторые международные аспекты энергетической политики ФРГ в 
начале XXI в. Ни одна работа, однако, не была посвящена изучению данной проблематики целиком.

Период активных изменений в энергетической политике ФРГ связан с окончанием «эры Коля» и приходом к власти «красно-зеленой» коалиции в составе Социал-демократической партии Германии (СДПГ) и «Союза 90/Зеленые». В этот раз партия «Зеленых» впервые стала частью правящей коалиции, что позволило ей начать реализацию своих планов по изменению курса развития энергетического сектора Германии.

В коалиционном соглашении партий целый раздел был посвящен отказу от атомной энергетики. Несколько раз в тексте документа говорилось, что коалиция будет стремиться отказаться от атомной энергетики «так быстро, как это возможно» [1]. Как и было сказано в соглашении, последовали переговоры с производителями атомной энергии.

Был согласован и 11 июня 2001 г. подписан текст соглашения. Также было принято решение о запрете строительства новых атомных реакторов и определен срок эксплуатации существующих атомных реакторов (32 года), по истечении которого они должны быть остановлены, но не позднее 2021 г.

Для каждой из этих электростанций устанавливалось количество электроэнергии, после производства которого реакторы должны быть остановлены. Было также принято решение о запрете переработки отработанного ядерного топлива. Кроме того, устанавливался 10-летний мораторий на сооружение хранилища ядерных отходов и проведение любых дальнейших исследований в Горлебене. В 2002 г. принятые решения были закреплены в «Законе о регулируемом прекращении использования ядерной энергии для промышленного производства электроэнергии».

Решение об отказе от атомной энергии несло за собой как положительные, так и отрицательные последствия для страны. В долгосрочной перспективе после закрытия АЭС должна была исчезнуть потребность импорта ядерного топлива, которое поставлялось в Германию из России, Канады, Австралии и США в размере около 3,8 тыс. тонн в год.

Исчезла бы также необходимость дорогостоящей переработки немецкого ядерного топлива, которое перерабатывалось во Франции и Великобритании. По данным британской перерабатывающей ком- 
пании $B N F L$, за 20 лет сотрудничества с Германией в сфере переработки ядерного топлива компания заработала 1 млрд фунтов.

Наиболее острым вопросом, возникающим после принятия решения об отказе от атомной энергетики, становилось замещение не произведенной на АЭС энергии энергией из других источников. На момент принятия решения об отказе от атомной энергии доля АЭС в общем производстве электроэнергии составляла около $30 \%$. После отключения АЭС необходимо было бы найти замену этим 30 \% электричества. Вариантов было несколько: закупать электричество у соседей, например у Франции, Чехии или Польши, или увеличить производство электричества на своих мощностях, будь то угольные, газовые или другие ТЭС. При наилучшем раскладе заместить не произведенное на АЭС электричество могла бы альтернативная энергетика, но, так как в 2000 г. возобновляемые источники энергии (ВИЭ) производили лишь $6,8 \%$ потребленной страной электроэнергии (в 1990 г. - 3,4 \%) [2], необходимо было бы вложить большие финансовые средства, чтобы ускорить развитие ВИЭ.

«Красно-зеленая» коалиция выбрала именно этот сложный путь развития альтернативной энергетики. Еще 1 апреля 2000 г. вступил в силу Закон о возобновляемых источниках энергии - ЗВИЭ (нем. Erneuerbare Energie Gesetz - EEG) [3]. Одной из целей данного закона было двукратное увеличение доли электроэнергии, полученной из ВИЭ, в общем потреблении электроэнергии к 2010 г.

В законе устанавливались специальные тарифы для различных видов энергии. Согласно этим тарифам, производителю возвращалось бы 5-10 \% стоимости производства энергии из ВИЭ в течение 20 лет. При этом предусматривалось постепенное снижение тарифов (дегрессия), чтобы стимулировать модернизацию энергетических установок и снизить стоимость производства электроэнергии. Также законом закреплялось преимущество электричества из ВИЭ в плане подключения к сетям.

Таким образом, принятие закона стимулировало инвестиции в сферу ВИЭ, делало производство электроэнергии из этих источников более выгодным для производителей, а также объявляло «зеленую» электроэнергию приоритетной. В период с 2000 по 2005 г. наблюдался стабильный рост доли ВИЭ в общем потреблении электричества. В 2003 г. суммарный объем государственного финансирования в области ВИЭ составил 1,67 млрд евро, из них 1,225 млрд евро планирова- 
лось потратить на выплаты по ЗВИЭ. Такая государственная поддержка способствовала привлечению инвестиций.

За 2000-2005 гг. доля атомной энергии в общем производстве электроэнергии снизилась с 34,5 до $31 \%$, а доля ВИЭ в общем потреблении электроэнергии увеличилась с 6,2 до 10,2\%. Исходя из этого, можно сделать вывод, что Германии удалось недостаток энергии заместить «зеленой».

В период нахождения у власти «красно-зеленой» коалиции началось развитие проекта строительства Североевропейского газопровода - СЕГ (нем. Nordeuropäische Gaspipeline), первого газопровода, напрямую связавшего Россию и ЕС.

8 сентября 2005 г. канцлер ФРГ Г. Шредер и президент Российской Федерации В. Путин подписали соглашение о строительстве СЕГ. Это произошло на месяц раньше, чем планировалось, так как 18 сентября в ФРГ должны были состояться внеочередные парламентские выборы, а соперница Г. Шредера - лидер союза ХДС/ХСС А. Меркель - не обозначила свою позицию по данному проекту.

В 2000 г. доля российского газа в импорте Германии составляла $45 \%$, Норвегии - 27 \%, Нидерландов - $22 \%$. В 2005 г. Россия поставляла 40 \% импортируемого Германией газа, Норвегия - 29 \%, Нидерланды - $21 \%$ [4]. Несмотря на снижение доли России в импорте газа, 9 мая 2005 г. на пресс-конференции с В. Путиным по случаю 60-летия со дня окончания Второй мировой войны канцлер Германии назвал Россию «важнейшим энергетическим партнером Германии» [5].

Совместное с Россией строительство газопровода шло в русле внешней политики правительства Г. Шредера. Периоду его канцлерства была характерна переориентация приоритетов с трансатлантических отношений на внутриевропейские [6, с. 263]. Наблюдалось несогласие ФРГ и США по некоторым вопросам. Важнейшим из таких расхождений во мнениях было осуждение Германией ввода войск НАТО в Ирак [6, с 256-277]. В этом вопросе ФРГ была солидарна с мнениями Франции и России.

Однако в вопросах внутриевропейского сотрудничества были свои нюансы. Если с Францией Германия довольно легко находила общий язык, то с новыми соседями - Польшей и Литвой - были недопонимания. Молодые члены ЕС были недовольны идеей строительства СЕГ в обход своих территорий. Премьер-министр Польши М. Белька назвал проект «политической проблемой», а депутат Евро- 
парламента от Литвы В. Ландсбергис сказал, что «этот новый альянс немцев и русских был спланирован для изменения политической карты Европы» и в случае осуществления этого проекта страны Балтии и Польша «будут оставлены на милость России».

Таким образом, пришедшая к власти «красно-зеленая» коалиция начала исторически значимый ряд реформ в энергетическом секторе Германии, который получил название «Энергетический поворот» (нем. Energiewende). Он был призван бороться с изменениями климата, снизить импорт энергоносителей, повысить энергоэффективность, ликвидировать риски ядерной энергетики, обеспечить энергетическую безопасность страны.

По итогам досрочных выборов в 16-й бундестаг была создана «большая коалиция» ХДС/ХСС и СДПГ. В коалиционном договоре говорилось о том, что Германии нужно создать концепцию энергетической политики. Подчеркивалось, что христианские и социальные демократы имеют разные подходы к вопросу использования атомной энергии, поэтому не подлежали изменению все принятые ранее по этому вопросу решения, такие как соглашение от 14 июня 2000 г. между правительством и производителями энергии, а также последнее издание закона об атомной энергии. В соглашении заявлялось, что уже в 2006 г. начнутся переговоры по вопросу субсидирования добычи угля в Германии. Кроме того, была озвучена идея создания организации IRENA (англ. International Renewable Energy Agency, нем. International Agentur für erneuerbare Energie, pус. Международное агентство по возобновляемым источникам энергии). Также планировалось интенсифицировать продажи «зеленой» энергии за рубеж [7].

Важным фактом было упоминание в разделе о европейском сотрудничестве «стратегического партнерства с Россией» (нем. Strategische Partnerschaft mit Russland) и, более того, расчета на строительство долгосрочного партнерства с Россией «без односторонней зависимости» (нем. ohne einseitige Abhängigkeiten). Об энергетическом партнерстве с другими странами в соглашении не говорилось [7].

За время существования «большой коалиции» в сфере энергетики был принят ряд решений. В июле 2002 г., после истечения срока действия Договора об учреждении Европейского объединении угля и стали, министры энергетики стран ЕС приняли решение прекратить субсидирование национальных производителей угля к 2010 г. Страны - члены ЕС договорились повторно обсудить данный вопрос в 
2007 г. 8 августа 2007 г. правительство ФРГ приняло законопроект о финансировании затрат, связанных с прекращением угледобычи, запланированным к 2018 г.

Решение отказаться от добычи угля в стране диктовалось экономическими соображениями: тонна угля в Германии стоила 200 евро, что было в 3,3 раза дороже тонны угля на мировом рынке. Таким образом, планировалось обеспечить немецкие ТЭЦ более дешевым зарубежным углем, импортируемым в первую очередь из стран ЕС, ЮАР, СНГ, Австралии, Колумбии, США, Канады, России и других стран.

Экономически отказ от добычи угля оправдан и выгоден, однако он повышает зависимость Германии от импортного сырья. Это противоречит принятой ЕС в 2000 г. «Зеленой книге» под названием «На пути к европейской стратегии для безопасности энергетических поставок», в которой в качестве важного фактора стабильности энергетики зафиксирована диверсификация как видов используемых энергоносителей, так и их поставщиков.

Проект строительства Североевропейского газопровода получил развитие в период работы «большой коалиции». Так как коалиционное соглашение закрепляло ведущую роль СДПГ в сфере энергетики (устанавливался запрет на изменение решений по вопросам энергетики, принятых до выборов, пост федерального министра по охране окружающей среды, охране природы и ядерной безопасности занял 3. Габриэль, а пост министра экономического сотрудничества и развития заняла X. Вичорек-Цойль - оба члены СДПГ), отказываться от осуществления проекта не планировалось.

30 ноября 2005 г. была создана компания North European Gas Pipeline Company (NEGP), в октябре 2006 г. переименованная в Nord Stream AG. Доля Газпрома в компании составила $51 \%$, а немецких E.ON Ruhrgas и Wintershall Holding AG - по 24,5 \%. В июне 2008 г. в состав акционеров вошла нидерландская газовая компания N.V. Nederlandse Gasunie.

Она получила $9 \%$ акций за счет долей немецких акционеров, которые сократились до $20 \%$. Аналогично $9 \%$ акций за счет немецких акционеров получила французская компания GDF Suez, подписавшая договор об участии в проекте в июне 2010 г. Таким образом, по состоянию на 2015 год Газпрому принадлежит 51 \% акций компании, немецким акционерам E.ON Ruhrgas и Wintershall Holding AG- 
по 15,5\%, а нидерландской компании N. V. Nederlandse Gasunie и французской GDF Suez - по $9 \%$.

Дополнительным аргументом в пользу строительства послужила «газовая война» России и Украины в конце 2005 - начале 2006 г. Конфликт между двумя странами по поводу цены на российский газ и стоимости транзита газа через Украину привел к трехдневному падению поставок газа в Европу. Венгрия заявила о падении поставок из России на 40 \%, Австрия, Словакия и Румыния - на треть, Франция на 25-30 \%, Польша - на 14 \%. Италия заявила о недостаче 32 млн кубометров газа за период с 1 по 3 января 2005 г. Германия также заявила о снижении количества получаемого газа, однако точные цифры озвучены не были.

В связи с этими событиями новоизбранный канцлер А. Меркель повторила закрепленное в коалиционном соглашении намерение о разработке энергетической стратегии Германии. Стало очевидно, что для обеспечения энергетической безопасности страны мало стратегического партнерства с Россией. Страны-транзитеры также оказывали существенное влияние на стабильность поставок.

Уже будучи экс-канцлером и главой комитета акционеров компании Nord Stream AG, Г. Шредер заявил, что нужно искать энергетической независимости не от России, а от существующих транзитных схем, где 80 \% трубопровода проходіт по территории Украины [8]. В этом контексте строительство газопровода из России в Германию, минуя транзитные страны, выглядело рациональным.

В 2006 г. Газпром поставил 23,9 \% всего импортируемого Европой газа (включая Турцию), что составило 161,5 млрд кубометров. На долю Германии пришлось 34,4 млрд кубометров, или 21,3 \% от общего объема газа, что делало Германию главным в Европе потребителем российского газа. При общем потреблении газа Германией в 2006 г. в объеме 93,5 млрд кубометров поставки из России составили 36 \% от всего потребленного объема. Таким образом, Германия была сильно подвержена влиянию возможных перебоев в поставках и нуждалась в надежном источнике газа. Поэтому проект «Северный поток» с газотранспортной мощностью в 55 млрд кубометров в год мог гарантировать Германии поставку необходимых ей объемов газа.

Несмотря на то что при строительстве газопровода из России в Германию зависимость Германии от России, казалось бы, должна была возрасти, при отказе от него Германия все так же продолжила бы 
покупать газ у России, однако была бы зависима от настроений транзитных стран. А при строительстве газопровода Германии открывалась возможность увеличить закупки российского газа, что могло быть особенно актуально для осуществления немецкого «Энергетического поворота».

Однако не все страны приветствовали строительство «Северного потока». 25-26 ноября 2005 г. на 24-й сессии Балтийской ассамблеи, членами которой являются Литва, Латвия и Эстония, была принята резолюция «Об опасностях, связанных со строительством газопровода в Балтийском море» (Resolution on Dangers Connected with Construction of the Gas Pipeline in the Baltic Sea). В ней страны требовали, чтобы их экологические и экономические интересы были учтены.

Польша заявляла, что невыгодно строить газопровод, который будет в 2,5-3 раза дороже наземного аналога через территории Эстонии, Литвы, Латвии и Польши. Премьер-министр страны сообщил, что будет продвигать идею строительства газопровода через территорию Польши. В 2006 г. министр обороны Польши сравнил договор о строительстве газопровода с пактом Молотова - Риббентропа, тем самым объявив строительство газопровода напрямую из России в Германию сговором, не учитывающим интересы соседних стран и даже вредящим им.

Правительство Эстонии отклонило просьбу компании Nord Stream AG разрешить ей исследовать морское дно в своей исключительной экономической зоне (ИЭЗ), тем самым исключив возможность строительства газопровода в своих водах.

Швеция также в целом негативно отнеслась к проекту. Так как газопровод должен был пройти по ИЭЗ страны, для начала строительства необходимо было получить разрешение от шведских властей. В феврале 2008 г. Швеция возвратила компании Nord Stream AG заявку на получение разрешения и высказала мнение, что информация в ней не соответствует действительности. В 2009 г. страна продлила срок рассмотрения проектных документов газопровода на два месяца, тем самым откладывая принятие решения о выдаче разрешения. Шведские сомнения были связаны с вопросами безопасности судоходства и рыбного промысла, использования прибрежных ветряных электростанций. Озабоченность руководства страны вызвали также вопросы государственной безопасности. Министр обороны Швеции М. Оденберг и лидер оппозиции У. Мессинг высказали опа- 
сения, что площадка для обслуживания газопровода, построенная у берега шведского острова Готланд, может использоваться для тайного наблюдения за передвижением военных и гражданских судов в Балтийском море.

Для Дании главным вопросом было то, по какому маршруту пройдет труба газопровода. Рассматривались различные варианты. В 2008 г. был предложен так называемый «S-маршрут». В нем были учтены зоны залегания химического оружия времен Второй мировой войны, а также интересы рыбаков.

Финляндия не выступала принципиально против проекта, однако выражала озабоченность его экологической составляющей. Министерство охраны окружающей среды Финляндии хотело, чтобы маршрут прокладки трубы проходил южнее запланированного. Впоследствии желание министерства было удовлетворено.

Вместо строительства «Северного потока» Беларусь выступала за строительство второй ветки газопровода «Ямал - Европа», проходящего по ее территории, предлагая взамен пятилетний бесплатный транзит газа [9].

Громкое заявление было сделано послом США в Швеции М. Вудом. В своей статье в газете Svenska Dagbladet он заявил, что Европа и США не должны увеличивать зависимость от России, которую он назвал «ненадежным поставщиком энергии». Он также призвал Швецию воспрепятствовать реализации проекта. В ответ на это Федеральное правительство Германии направило официальный протест в посольство США в ФРГ.

Поддержка проекта Германией была значительной. 8 марта 2008 г. на встрече с президентом России Д. Медведевым канцлер ФРГ А. Меркель заявила, что будет «работать над устранением препятствий» реализации проекта, создаваемых Швецией, Польшей и другими балтийскими странами [10]. После очередной газовой войны между Россией и Украиной на рубеже 2008-2009 гг. А. Меркель сделала несколько заявлений в поддержку проекта. На встрече с В. Путиным 16 января 2009 г. канцлер подтвердила, что Германия поддерживает строительство «Северного потока» и будет последовательно его реализовывать. А две недели спустя в письме к главе Еврокомиссии Ж. М. Баррозу и к чешскому премьер-министру М. Тополанеку (Чехия тогда председательствовала в Совете Европейского союза) А. Меркель указала на необходимость диверсификации и призвала 
поддержать проект «Северный поток». Канцлер писала, что страны ЕС должны одинаково поддерживать все проекты по строительству газопроводов. Она указала на необходимость диверсификации не только поставщиков газа, но и путей его доставки.

Несмотря на то что приоритетным для Германии был проект «Северный поток», она также обращала внимание и на другие проекты по поставкам газа в Европу. 24 июня 2009 г. канцлер ФРГ отметила, что для Германии было бы очень хорошо, если бы были реализованы и «Северный поток», и «Южный поток», и «Набукко» [11]. Однако ранее А. Меркель заявила, что проект «Набукко» не должен спонсироваться из правительственных средств. Это заявление было сделано уже после того, как на Энергетическом саммите ЕС 26-27 января 2009 г. было принято решение выделить 250 млн евро на реализацию проекта. Такое двоякое отношение к проекту можно объяснить следующим образом.

Во-первых, по газопроводу «Набукко» поставлять газ в Германию не планировалось. Однако этот вариант был возможен при транзите газа из «Набукко» по австрийским газопроводам. Во-вторых, 20 марта 2009 г. на очередном саммите ЕС «Набукко» вновь получил статус приоритетного проекта ЕС. За три дня до этого при активном участии Германии проект потерял данный статус, однако после того, как страны Восточной Европы выразили свое возмущение, а Румыния пригрозила заблокировать принимаемый на саммите инвестиционный план, приоритетный статус проекту был возвращен. Для ФРГ это означало, что львиная доля от 8 млрд евро, в которые оценивалось осуществление проекта, будет выплачена из кармана Германии - главного донора ЕC.

При этом осуществление проекта «Южный поток» не предполагало финансовых вложений Германии, а «Набукко» требовал инвестиций. Проект «Набукко» способствовал диверсификации поставщиков газа, однако этот газ не планировалось поставлять в Германию.

Таким образом, письмо канцлера к главе Еврокомиссии и к чешскому премьер-министру было призвано уравнять значимость трех проектов газопроводов для ЕС, повысив значимость «Северного потока» и снизив значимость «Набукко», тем самым подняв приоритет газопровода, идущего в Германию, и снизив приоритет газопровода, не влияющего напрямую на энергетическую безопасность ФРГ. 
В период первого канцлерства А. Меркель высказалась в поддержку проекта «Дезертек» - строительства солнечных теплоэлектростанций в Сахаре. Произведенной там энергии хватало бы не только для местного потребления, но и для экспорта, в первую очередь в средиземноморские страны Европы. При покрытии солнечными электростанциями площади, соизмеримой с площадью Австрии, за год можно получить столько электроэнергии, сколько производится за год в мире. А если покрыть площадь 2500 квадратных километров (соизмеримо с Люксембургом), то можно компенсировать 15 \% потребностей Европы. Реализация такого проекта оценивается в 400 млрд евро: 350 млрд евро понадобится на строительство солнечных электростанций и 50 млрд - на прокладку новых линий электропередачи. А. Меркель выразила мнение, что проект хорошо вписывается в средиземноморскую политику ЕС и для его реализации можно использовать средства Союза. Она также отметила, что принять участие в реализации проекта решили немецкие компании.

«Большая коалиция» реализовала еще один проект, заложенный в правительственную программу, - создание Международного агентства по возобновляемым источникам энергии IRENA. Целью создания организации было продвижение ВИЭ во всем мире. IRENA была основана 26 января 2009 г. по инициативе правительства Германии. По состоянию на 2015 г. 140 стран являются членами организации (в том числе Республика Беларусь), 32 страны находятся в процессе вступления (в том числе Российская Федерация). Создание организации дало Германии площадку, на которой она могла продвигать свое видение будущего мировой энергетики, делиться опытом широкого использования альтернативных источников энергии, а также сотрудничать с другими странами в обмене энергетическими технологиями, в том числе экспортировать их.

Во время нахождения у власти «большой коалиции» были закреплены некоторые пути будущего развития энергетики страны. С отказом от производства угля до 2018 г. внутри страны и при сохранении постоянной доли угля в производстве электроэнергии началось увеличение импорта угля из-за рубежа. Началась реализация «Северного потока», было выражено отношение к «Набукко» и «Южному потоку», поддержано развитие проекта «Дезертек». Развитие газовых проектов, а также проектов альтернативной энергетики при закрытии местных угольных шахт делало перспективной замену производства 
энергии из угля на ее производство из газа, при сжигании которого производится меньше $\mathrm{CO}_{2}$, что более экологично. Импорт угля должен был уменьшиться, а импорт газа - увеличиться. Такой сценарий виделся вполне осуществимым при реализации проекта «Северный поток». А так как в коалиционном соглашении СДПГ и союза ХДС/ХСС отмечалась особая роль России как партнера в сфере энергетики, этот сценарий казался наиболее вероятным.

В 2009 г. к власти пришла «черно-желтая» коалиция в составе ХДС/ХСС и Свободной демократической партии (СвДП). Уход в оппозицию СДПГ позволил внести изменения в энергетическую политику.

28 сентября 2010 г. бундестаг наконец принял национальную энергетическую концепцию - Энергетическую концепцию 2050 [12], которая закрепила основные направления развития энергетики Германии до 2050 г. В ней закреплялась идея постепенного перехода от традиционных к альтернативным источникам энергии. Ставилась задача к 2050 г. производить 80 \% электроэнергии из ВИЭ при текущем показателе в $17 \%$. Чтобы достичь этого, планировалось постепенно сокращать общее потребление электроэнергии. Концепция закрепляла решение о прекращении добычи угля в Германии. Подчеркивалась необходимость диверсификации энергоносителей, стран-экспортеров и маршрутов поставок. Правящая коалиция обещала поддержку проектам, призванным содействовать диверсификации. Среди них - «Северный поток», «Набукко», «Дезертек», проект прокладки электрической «суперсети» по дну Северного моря. На европейском уровне продвигалась идея создания общеевропейского рынка электроэнергии и газа для обеспечения максимальной конкуренции и снижения цен для потребителей. Покрытие спроса на электроэнергию планировалось обеспечить в том числе за счет ее импорта. Импортировать предполагалось электроэнергию, полученную из ВИЭ. Основным поставщиком такой электроэнергии должна была стать Северная Африка. С принятием Энергетической концепции 2050 профильным министерствам и органам ФРГ была поручена разработка плана реализации проекта «Дезертек» [12].

Наиболее громким и спорным решением, закрепленным в концепции, было продление сроков эксплуатации АЭС. Атомная энергетика была объявлена мостом для постепенного перехода от традиционных к альтернативным источникам энергии. Планировалось про- 
длить сроки эксплуатации АЭС в среднем на 12 лет: для АЭС, введенных в эксплуатацию до 1980 г. включительно, - на 8 лет, для более молодых АЭС - на 14 лет. Таким образом, последняя АЭС должна была прекратить работу в 2036 г. До 2016 г. планировалось взимать с производителей ядерной энергии налог на ядерное топливо и направлять эти деньги на развитие альтернативной энергетики. С октября 2010 г. ожидалось возобновление исследований возможности захоронения ядерных отходов в Горлебене. 8 декабря 2010 г. федеральный президент К. Вульфф подписал Закон о продлении сроков эксплуатации АЭС.

После аварии на АЭС «Фукусима-1» в марте 2011 г. мировая общественность вновь задумалась об опасности ядерной энергетики. В Германии прошли многочисленные акции против использования атомной энергии. Около 80 \% населения выступало за полный отказ от атомной энергии. 14 марта 2011 г. правительство приняло решение о трехмесячной приостановке действия Закона о продлении сроков эксплуатации АЭС, принятого за полгода до событий в Японии. Это решение предусматривало немедленную остановку семи старейших реакторов, введенных в эксплуатацию до 1980 г. 6 июня, в конце срока трехмесячного моратория, правительство приняло план постепенного и полного отказа от ядерной энергии к 2022 г. Согласно этому плану семь остановленных по решению 14 марта АЭС и АЭС «Крюммель», на которой с 2009 г. проводились технические работы, больше вводить в эксплуатацию не планировалось. Для оставшихся девяти АЭС был разработан план постепенного вывода из эксплуатации. По истечении 2022 г. все АЭС Германии должны прекратить работу.

Это вызвало неоднозначную реакцию внутри страны и за рубежом. Президент Чехии В. Клаус назвал решение правительства ФРГ популистским. По его мнению, за ним скрывалось лоббирование интересов производителей альтернативной энергии. Министр промышленности Франции Э. Бессон заявил, что «Германия будет более зависимой от ископаемого топлива и импорта», и подчеркнул, что «немецкое электричество будет более дорогим и загрязняющим окружающую среду». А. Ловержон, исполнительный директор государственной французской компании Areva SA (самой большой в мире по производству оборудования для атомных электростанций), выразила сомнение в том, что Германии хватит польского угля. Кроме того, использование угля сопряжено с экологическими проблемами. По ее 
мнению, Германия пойдет по пути Австрии и будет импортировать электроэнергию из соседних стран, произведенную с большой долей вероятности на АЭС. Действительно, в апреле 2011 г. импорт электроэнергии из Франции впервые превысил экспорт Германии в эту страну [13]. Так как 79 \% французской электроэнергии производят АЭС [13], можно сказать, что Германия покупает у Франции ту же энергию, что могла бы произвести сама.

Вскоре после парламентских выборов в Германии, через чьи территориальные воды и/или ИЭЗ должен был пройти «Северный поток», начали выдавать разрешения на строительство, и в феврале 2010 г. таковое было получено для данного газопровода.

9 апреля 2010 г. началось строительство первой нитки газопровода. В организованной по этому поводу торжественной церемонии приняли участие президент России Д. Медведев и комиссар ЕС по энергетике Г. Эттингер. А. Меркель выступила с видеообращением: «Нашей общей целью является партнерство в энергетической сфере, основанное на равенстве и рассчитанное на долгосрочный период. Оно предоставит возможности сотрудничества и развития бизнесу по обе стороны трубы. В действительности, “Северный поток” демонстрирует широкий экономический потенциал, заложенный в такое партнерство». Канцлер отметила, что благодаря «Северному потоку» Европа получит надежное газоснабжение, а Россия - надежного покупателя. Она также обратила внимание на то, что строительство газопровода затрагивает интересы многих стран региона. Меркель выразила благодарность всем тем, кто оказал политическую поддержку проекту.

В мае 2011 г. параллельно со строительством первой ветки газопровода началось строительство второй. Первая ветка была завершена в июне 2011 г., и 8 ноября в г. Люмбине состоялось торжественное открытие. На церемонии присутствовали А. Меркель, президент России Д. Медведев, премьер-министр Нидерландов М. Рютте и премьер-министр Франции Ф. Фийон, комиссар ЕС по энергетике Г. Эттингер.

А. Меркель назвала «Северный поток» примером сотрудничества между Россией и ЕС в сфере, имеющей ключевое значение для национальных экономик. Канцлер вновь подчеркнула «справедливые интересы» стран Балтийского моря и успешное сотрудничество «политики и экономики». Она повторила, что компании Nord Stream AG 
и заинтересованным органам стран Балтийского моря удалось достичь «сбалансированного решения» (нем. ausgewogene Lösung) [14].

Канцлер также отметила, что, несмотря на диверсификацию, Россия является «исключительным» партнером (нем. herausragenden Partner) по европейскому энергоснабжению и останется им в следующие десятилетия.

В тот же день федеральный министр экономики и технологий ФРГ Ф. Реслер дал интервью газете Die Welt, которое было опубликовано на сайте федерального правительства Германии под заголовком «Северный поток - европейский проект». В нем политик отметил, что «Северный поток» - это общеевропейский проект, так как газопровод включен в Трансъевропейские энергетические сети (TEN-E), а акционерами проекта помимо российской и немецких компаний являются также французская и нидерландская компании. Ф. Реслер отметил, что не видит причин усиления зависимости Германии от российского газа, подчеркнув, что в сравнении с другими странами ЕС структура импорта энергоносителей Германии достаточно диверсифицирована. Кроме того, интересы России и Германии взаимны - России нужен стабильный покупатель, как и Германии нужен столь же надежный поставщик [15].

18 апреля 2012 г. было завершено строительство второй ветки газопровода. 8 октября 2012 г. она была введена в эксплуатацию. В своем видеообращении канцлер А. Меркель во многом повторила сказанное в обращении по случаю запуска первой ветки газопровода. Она вновь поблагодарила регулирующие органы заинтересованных стран за поддержку. Президент России заявил, что газ будет поставляться без транзитных рисков, стабильно и бесперебойно, и подчеркнул: «Мы это гарантируем» [16].

Проект «Северный поток» только завершился, но уже активно шли дискуссии по поводу его расширения - строительства дополнительных веток. 19 июля 2011 г. канцлер Германии заявила, что страна не заинтересована в расширении «Северного потока». Однако спустя год из Берлина пришли первые сигналы возможности планов расширения. 4 июня 2012 г. на встрече канцлера ФРГ А. Меркель и президента России В. Путина было заявлено, что прокладка дополнительных труб по дну Балтийского моря осуществима. А. Меркель отметила, что оппозиция проекту в лице опасающихся усиления зависимости от российского газа немцев ослабевает. В. Путин же указал на то, 
что дополнительные объемы газа из России не усилят зависимость Германии, а лишь заместят сокращающиеся ресурсы из Северного моря. Он также заявил, что в расширении проекта заинтересованы Скандинавские страны и Великобритания.

Период работы «черно-желтой» коалиции в 2009-2013 гг. стал одним из самых неоднозначных касательно энергетики. В первой половине четырехлетнего срока правительство союза ХДС/ХСС и СвДП сделало кардинальный разворот от энергетической политики «большой коалиции» 2005-2009 гг., которая по большей части была детищем СДПГ. Однако во второй половине срока после аварии на Фукусиме-1 правящая коалиция сделала очередной поворот на 180 градусов относительно своей предыдущей политики. Можно сказать, что в вопросе атомной энергетики союз ХДС/ХСС полностью вернулся к программе своего главного политического соперника - СДПГ.

Одним из немногих вопросов, ответ на который не изменился за период работы 17-го бундестага, был вопрос строительства «Северного потока». Проект последовательно поддерживался Германией, А. Меркель оказывала политическую поддержку его развитию. Вопрос расширения «Северного потока» и прокладки дополнительных труб, однако, не получил столь однозначной поддержки Германии. Несмотря на постепенный отказ от ядерной энергии, закрытие угольных шахт, руководство Германии было уверено, что увеличение импорта газа из России не понадобится. А если и понадобится, это можно будет сделать и за счет двух существующих веток газопровода, которые были загружены лишь на $50 \%$.

По результатам выборов в 18-й бундестаг вновь была сформирована «большая коалиция». 27 ноября 2013 г. было подписано коалиционное соглашение, в котором закреплялись основные направления развития энергетической политики на четыре года. Ее главной идеей был назван треугольник «экологичность - надежность снабжения разумная цена». По мнению коалиции, отказаться от традиционных источников энергии в обозримом будущем невозможно, поэтому необходимо строить высокоэффективные электростанции. Большое внимание уделялось общеевропейским энергетическим вопросам. Коалиция выступила за повышение безопасности АЭС в Европе, за поднятие вопросов энергетики на общеевропейский уровень. Была объявлена идея создания общеевропейского энергетического рынка. 
В 2014 г. начался очередной газовый конфликт между Украиной и Россией. В апреле, после мартовского референдума о присоединении Крыма к Российской Федерации, Россия в одностороннем порядке денонсировала Харьковские соглашения, в которых ей предоставлялось право базировать свой Черноморский флот в Севастополе в обмен на предоставление Украине скидки на газ в размере 100 долларов за тысячу кубометров. Кроме того, была отменена скидка, полученная Украиной в декабре 2013 г. при подписании ряда соглашений президентами России и Украины. Платить по возросшей цене Украина не могла, и 16 июня из-за накопившегося долга в 5,3 млрд долларов Россия прекратила поставки газа на Украину, которая с этого момента могла рассчитывать лишь на реверсные поставки из Польши, Словакии и Венгрии. Реверсные поставки газа уже осуществлялись немецким концерном RWE c 15 апреля, так как Украине было дешевле купить газ у Германии по 380 долларов за тысячу кубометров, чем у России за 485.

Аналогичная ситуация имела место около десяти лет назад, когда из-за отбора Украиной транзитного газа поставки в Европу значительно сократились. Чтобы избежать этого, лидеры ЕС стали активно участвовать в процессе достижения соглашения Украиной и Россией.

30 ноября 2014 г. Россия, Украина и Европейская комиссия подписали «зимний план» об условиях поставки и транзита газа по территории Украины до конца марта 2015 г. План включал обязательство Украины погасить долг в размере 3,1 млрд долларов до конца этого года. Поставки газа на Украину планировалось осуществлять по предоплате.

Подписанию плана предшествовали долгие переговоры и консультации. Для ЕС достижение соглашения между Россией и Украиной было крайне важным, так как под вопросом была безопасность поставок газа в Европу в зимний период. Когда стало понятно, что Россия будет настаивать на возврате долга за газ, А. Меркель призвала ЕС оказать финансовую поддержку Киеву, чтобы гарантировать реализацию обсуждаемого «зимнего плана». Чтобы подтолкнуть Украину к подписанию соглашения, А. Меркель заявила, что в случае, если договор с Россией подписан не будет, Европа прекратит реверсные поставки на Украину, так как сама будет нуждаться в запасах газа. Тогда единственным выходом для Украины стал бы отбор газа, идущего по ее территории в Европу, что разозлило бы западные стра- 
ны. Канцлер Германии призвала президента России В. Путина заключить газовое соглашение с Украиной, пока не началась зима.

Таким образом, Германия предприняла все возможные политические меры по обеспечению благоприятных условий для подписания соглашения между Россией и Украиной, которое гарантировало бы Европе стабильную поставку газа зимой 2014-2015 гг.

Еще одним важным фактором, влияющим на энергетические отношения в Европе, стал ввод Западом политических и экономических санкций против России в ответ на события в Крыму весной 2014 г. и ответный ввод санкций Россией.

Стала вызывать беспокойство перспектива прекращения поставок российских энергоносителей в Европу. В краткосрочной перспективе газ, находящийся в немецких подземных хранилищах, мог бы компенсировать потери импорта, однако в долгосрочной перспективе ситуация значительно ухудшилась бы.

Другим вариантом российских действий была возможность увеличения цены на газ для европейских покупателей. Однако Россия должна была выполнять обязательства по подписанным контрактам. Кроме того, при повышении цен европейские покупатели могли начать покупать энергоносители у других поставщиков, что отрицательно сказалось бы на бюджете России.

Важным событием в сфере энергетики в период работы «большой коалиции» стало и принятие решения о создании Энергетического союза ЕС 20 марта 2015 г. на саммите ЕС в Брюсселе. Пятью главными аспектами Энергетического союза были объявлены надежность энергоснабжения, создание единого внутреннего энергетического рынка, энергоэффективность, уменьшение выбросов парниковых газов в атмосферу, а также исследования и инновации в энергетической сфере.

А. Меркель на саммите выразила позицию Германии относительно того, каким должен быть Энергетический союз. Она поддержала идею транспарентности при заключении контрактов на поставку газа, однако подчеркнула, что коммерческая тайна должна соблюдаться. Это шло в разрез с идеей Д. Туска, главы Евросовета и одного из инициаторов создания Энергетического союза, который предлагал предоставить Еврокомиссии право проверять договоры с поставщиками газа. Тем самым Еврокомиссия получила бы право последнего слова и решающего голоса при заключении газовых контрактов. Фе- 
деральный министр экономики 3. Габриэль заявил, что такое «общеевропейское» заключение договоров ограничило бы рыночную конкуренцию и совместные переговоры можно проводить только в качестве исключения [17].

Создание Энергетического союза ЕС было во многом направлено на снижение зависимости от российских энергоносителей, в первую очередь от газа, так как шесть из 28 стран ЕС зависели от российского газа на $100 \%$ [17].

Кроме того, цены на российский газ различаются для стран ЕС. Так, Польша платит 525,5 долларов за тысячу кубометров газа, в то время как Великобритания - 313,4 доллара. Рассмотрение Европейской комиссией договоров до их подписания или совместные закупки газа Евросоюзом могли бы снизить стоимость газа для отдельных стран. Однако при принятии решения о создании Энергетического союза Европейская комиссия такие полномочия не получила.

Официальную информацию о внешней энергетической политике ФРГ можно получить на сайте внешнеполитического ведомства ФРГ, где ей посвящен один из разделов об энергетике. Раздел содержит четыре подраздела, каждый из которых говорит об отдельном аспекте внешней энергетической политики Германии.

Первый подраздел посвящен энергетической безопасности. В нем обозначены вызовы, стоящие перед Германией и ЕС в сфере энергетики, среди которых диверсификация энергоносителей, их источников и путей доставки для обеспечения наибольшей энергетической безопасности и независимости; совершенствование диалога со странами-поставщиками, странами-транзитерами и странами - крупнейшими потребителями энергоносителей, в первую очередь с новыми индустриальными странами, и др.

Во втором подразделе описывается роль Германии в продвижении идеи «Энергетического поворота». Германия называется пионером в области ВИЭ с многолетним опытом. Особенно подчеркивается решение правительства Германии отказаться от атомной энергии к 2022 г.

Также развитие ВИЭ связывается со становлением нового сектора промышленности - сектора альтернативной энергетики, в котором к 2030 г. будет создано более 700 тыс. рабочих мест, что превысит количество занятых в самом большом секторе промышленности автомобилестроении [18]. 
Третий подраздел - «Модный за рубежом знак “Электричество made in Germany"» говорит о том, что «Энергетический поворот» стал фирменным знаком Германии, а технологии в сфере ВИЭ под знаком «Made in Germany» имеют большой спрос на мировом рынке. Успешное развитие ВИЭ привело к тому, что многие страны приняли у себя законы, основанные на принципах немецкого ЗВИЭ. Подчеркивается, что путь, по которому ЕС планирует идти в сфере энергетики и защиты климата, параллелен курсу энергетической политики Германии [18].

В четвертом подразделе - «Возобновляемая энергетика - в мире» - говорится о том, что во всех странах есть условия для развития ВИЭ - достаточно ветра, солнца, воды, геотермальных ресурсов и биомассы. Зачастую не хватает лишь знаний о том, как эти ресурсы использовать. Поэтому важным шагом в расширении использования ВИЭ в мире стало основание международной организации IRENA в 2009 г. (инициатором создания организации выступила ФРГ).

Таким образом, Германия отводит себе ведущую роль в продвижении альтернативной энергетики в мире. Она готова делиться научными и промышленными достижениями для продвижения «Энергетического поворота» в мире.

Еще один раздел сайта посвящен партнерству в сфере энергетики. В связи с высокой зависимостью Германии от импорта энергоносителей, растущим мировым спросом на энергию, а также с осуществлением «Энергетического поворота» правительство Германии заключило ряд соглашений в сфере энергетики со странами - производителями, транзитерами и потребителями энергии.

Энергетическое партнерство закреплялось подписанием заявления о намерениях или соглашения. Цель партнерства заключается в оказании поддержки странам-партнерам в продвижении ВИЭ, повышении энергоэффективности и распространении современных технологий в сфере энергетики. Тем самым создаются экспортные возможности для немецких предприятий, создающих такие технологии.

На сайте представлен перечень стран - партнеров Германии в сфере энергетики: Бразилия, Китай, Индия, Марокко, Нигерия, Норвегия, Россия, ЮАР, Тунис и Турция.

С Бразилией Германия заключила соглашение в 2008 г. Страны договорились сотрудничать в сфере ВИЭ, энергоэффективности, современных технологий и защиты климата. Развитие атомной энерге- 
тики Бразилии тесно связано с колебаниями внутренней энергетической политики Германии. Так, в 2010 г. Германия предложила свои госгарантии на сумму 1,7 млрд долларов для строительства бразильской АЭС «Ангра-3». Это было сделано до того, как правительство Германии приняло решение о продлении сроков эксплуатации немецких АЭС.

Однако год спустя, после возврата Германии к отказу от атомной энергии, правительство выдвинуло новые условия госгарантий, включающие в себя проверку безопасности АЭС в случае землетрясений, проведение стресс-тестов. Такие действия были восприняты негативно. Гринпис заявил, что со стороны Германии непоследовательно закрывать АЭС в своей стране и поддерживать их строительство за рубежом.

Партнерство с Китаем было учреждено в виде Германо-китайского форума экономического и технологического сотрудничества в 2006 г. Весной 2013 г. страны заключили два договора - «О сотрудничестве в сфере экономии энергии и повышения энергоэффективности» и «О сотрудничестве в сфере ВИЭ».

По инициативе канцлера Германии А. Меркель и премьер-министра Индии М. Сингха в 2006 г. был основан Германо-индийский энергетический форум. В 2015 г. в рамках очередного энергетического форума стороны подписали пять соглашений о сотрудничестве предприятий в сфере ВИЭ. Особое внимание было уделено сфере фотовольтаики.

С Марокко в 2012 г. было подписано заявление о намерениях создания энергетического партнерства. В рамках документа были созданы рабочие группы: «ВИЭ и линия ЕС» (выработка солнечной энергии и ее экспорт в ЕС), «Развитие проекта “Дезертек” в Марокко», «Сотрудничество для развития». Ключевое значение уделялось развитию ВИЭ для последующего экспорта электроэнергии в ЕС.

Основы партнерства Германии и Нигерии были заложены в 2007 г., когда состоялась первая Германо-нигерийская энергетическая конференция. К концу 2012 г. состоялось уже шесть таких конференций. Во время визита президента Нигерии Джонатана в Берлин в апреле 2012 г. было подписано соглашение о финансировании строительства гидроэлектростанции на месте дамбы Кири на реке Гонгола. В обмен на помощь в осуществлении энергетических проектов Германия рассчитывала на поставку нигерийского газа в страну в виде 
сжиженного газа или по трубопроводам. Стоит отметить, что у Германии нет терминалов для принятия сжиженного газа.

С Норвегией у Германии особо тесное энергетическое партнерство. Она поставляет в Германию около трети импортируемого газа, уступая лишь России. На современном этапе главный проект немцев и норвежцев - NordLink - проект прокладки подводного электрического кабеля. 516 км кабеля будут проложены по дну Северного моря и соединят немецкий город Вильстер и норвежский Тонстад [19]. Этот кабель будет способствовать рациональному использованию ВИЭ. Когда на побережье Германии будет сильный ветер и оффшорные ветропарки будут вырабатывать много энергии, электричество будет идти по кабелю в Норвегию, где будет направляться в ГАЭС гидроаккумулирующие электростанции. Суть работы ГАЭС заключается в том, что, когда возникают излишки электроэнергии, насосы на таких ГАЭС качают воду из нижнего водохранилища в верхнее. Таким образом удается аккумулировать энергию, которую никто в данный момент не может потребить. Когда же на немецком побережье будет штиль, дамбы на норвежских ГАЭС откроются, вода потечет вниз и выработает энергию, которая будет направлена в Германию. Таким образом, Норвегия станет «аккумуляторной батареей» Германии. 10 февраля 2015 г. между норвежскими и немецкими предприятиями было подписано соглашение о сотрудничестве для реализации данного проекта [19].

Энергетическое партнерство с Россией играет огромную роль для обеспечения Германии энергетическими ресурсами, иногда даже большую, чем Германии хотелось бы. Россия является крупнейшим поставщиком газа и нефти в ФРГ. Германию и Россию соединяет балтийский газопровод. Несмотря на санкции между Россией и Европой, Германия считает Россию надежным партнером, выполняющим свои обязательства по договорам на поставку энергоносителей.

Совместное заявление о намерениях подписано также между Германией и ЮАР в феврале 2013 г. Была создана рабочая группа высокого уровня, которая должна собираться на ежегодных встречах. Областью работы группы определялось развитие ВИЭ, повышение энергоэффективности, сотрудничество в сфере ядерной безопасности, технологическое сотрудничество в области CCS-технологий. Кроме того, Германия планировала перенять у ЮАР опыт в сфере фотовольтаики. В результате сотрудничества двух стран к 2030 г. планирова- 
лось снизить зависимость ЮАР от угля, из которого производится $90 \%$ электроэнергии, на $65 \%$.

С Тунисом заявление о намерениях Германия подписала в начале 2012 г. Оно похоже на заявление, подписанное с Марокко. Сотрудничество также планировалось в сфере ВИЭ, а именно в реализации проекта «Дезертек» и проекта по выработке солнечной энергии для экспорта в ЕС. Такая общность целей и задач привела к созданию Германо-арабского энергетического форума, на котором вопросы реализации африкано-европейских проектов стали обсуждаться на многостороннем уровне.

Партнерство с Турцией закреплено в Совместном заявлении Федерального министерства экономики и технологий ФРГ и Министерства энергетики и природных ресурсов Республики Турция о сотрудничестве в области энергетики. Был основан Турецко-германский энергетический форум. Он должен был проходить ежегодно, поочередно в Германии и в Турции. Турция также играла важную роль в возможном осуществлении проектов «Набукко» и «Южный поток».

Учитывая все вышеизложенное, можно отметить, что Германия сотрудничает в сфере энергетики как с реальными и потенциальными поставщиками (Россия, Нигерия), так и с крупнейшими потребителями (Китай, Индия). ФРГ также участвует в передаче современных технологий в области энергетики с целью повышения энергоэффективности и защиты окружающей среды. Можно сделать вывод, что Германии важна не только собственная энергетическая безопасность, но и развитие энергетики в мире в целом.

В ходе исследования сделаны следующие выводы.

В период нахождения у власти «красно-зеленой» коалиции в 1998-2005 гг. были заложены основы современной энергетической политики ФРГ. Было принято судьбоносное решение об отказе от использования ядерной энергии, дан «зеленый свет» строительству Ceвероевропейского газопровода, выражено твердое намерение государства поддерживать развитие возобновляемых источников энергии. Комплекс этих решений стал известен как «Энергетический поворот», который ФРГ реализует по сей день. Проводимая кабинетом Г. Шредера политика укрепляла энергетические отношения с Россией, иногда даже в ущерб внутриевропейским отношениям с новыми членами ЕС. Было положено начало процессу диверсификации путей поставки энергоносителей. Создавались возможности для наращива- 
ния импорта российского газа для собственного потребления или реэкспорта.

При создании «большой коалиции» в 2005 г. коалиционное соглашение закрепляло все достижения предыдущего кабинета и запрещало изменение принятых в предыдущей легислатуре решений. Это обусловило преемственность внешней энергетической политики. Было объявлено о «стратегическом партнерстве» с Россией, что в свете устойчивости внешней энергетической политики вылилось в укрепление двустороннего сотрудничества, выразившегося в последовательной реализации проекта «Северный поток» и в личной поддержке проекта канцлером А. Меркель.

Канцлер также выразила политическую поддержку проекту «Дезертек», для реализации которого, в отличие от «Набукко», предлагала выделить финансовые средства ЕС. В этом автор видит приоритет политической поддержки проектов развития возобновляемых источников энергии над проектами поставки традиционных энергоносителей в случае, когда данные проекты напрямую не затрагивают Германию.

В этот же период было принято решение об отказе от добычи угля, что согласовывалось с политикой «Энергетического поворота», однако шло вразрез с европейской политикой диверсификации, так как увеличивало зависимость Германии от импорта угля. Так как решение было принято с учетом экономической выгоды покупки дешевого зарубежного угля вместо добычи дорогого местного, сделан вывод о приоритете экономических факторов принятия такого решения над политическими.

По инициативе ФРГ в период нахождения у власти «большой коалиции» была создана международная правительственная организация IRENA, которая стала форумом для развития возобновляемых источников энергии в мире. Вероятно, создание данной организации с подачи Германии было призвано усилить вес Германии в мировой энергетике как лидера в области новейших технологий альтернативной энергетики, а также открыть пути для экспорта этих технологий в другие страны, в первую очередь в крупные развивающиеся государства, такие как Китай и Индия.

Переломным моментом в энергетической политике ФРГ стал приход к власти в 2009 г. «черно-желтой» коалиции и уход в оппозицию СДПГ. Это позволило новому кабинету провести ряд карди- 
нальных поворотов в энергетической политике страны, которые привели к возврату к политике «большой коалиции» 2005-2009 гг.

Идея продлить сроки действия АЭС возникла по прагматичным экономическим причинам. При их продлении переход к ВИЭ был бы более плавным и менее дорогостоящим. Отказ от этой идеи, однако, не имел отношения ни к экономике, ни к внешней политике, а был внутриполитическим действием для удовлетворения общественности, опасающейся возможности событий сценария Фукусимы, и для получения дополнительных очков на очередных парламентских выборах, что, несомненно, удалось.

Отношение к международным аспектам энергетики также было прагматичным. Право заключения контрактов и строительства трубопроводов закреплялось за предприятиями, государство брало на себя разработку общей энергетической политики. Это выразилось и в отношении ФРГ к перспективе расширения «Северного потока»: Германия не отрицала возможности такого расширения, однако дала понять, что для нее это не является приоритетным. Таким образом, государство дало согласие на осуществление проекта, но принятие окончательного решения оставило за энергетическими концернами.

Современная внешняя энергетическая политика Германии является результатом развития энергетической политики страны на протяжении последних 15 лет. Германия берет на себя активную роль в формировании энергетической политики ЕС. Идея о создании единого энергетического рынка союза появилась в Германии задолго до принятия решения о воплощении этого проекта в жизнь. В энергетическом конфликте Украины и России Германия также выступила активным посредником, в первую очередь с целью защиты собственных энергетических интересов.

На мировой арене Германия видит себя лидером и в сфере энергетики. Правительство ФРГ заключило ряд двусторонних договоров со странами в разных уголках мира с разным уровнем развития и потенциала. Сотрудничество налажено как с развитыми странами, так и с развивающимися, как с поставщиками энергоносителей, так и с потребителями. Ставя себя на место лидера в области возобновляемых источников энергии, Германия экспортирует современные технологии альтернативной энергетики, выполняя тем самым гуманитарную функцию, но зачастую также преследует экономическую выгоду в виде ответных поставок энергоносителей. 
Во внешней энергетической политике Германия руководствуется в первую очередь экономическими соображениями. Политическая нестабильность в Европе не оказывает существенного влияния на энергетический сектор страны. Для Германии как страны с высоким потреблением энергоносителей стабильность экономики зависит от энергетического сектора, который правительство старается оградить от последствий внешней политики страны и ЕС.

В долгосрочной перспективе, благодаря реализации амбициозного плана «Энергетического поворота», Германия при одновременном снижении энергопотребления, импорта энергоносителей и росте выработки энергии из альтернативных источников может превратиться из покупателя энергоресурсов в продавца. В таком случае ныне дорогостоящее и весьма затратное развитие возобновляемых источников энергии станет прибыльной частью промышленности, которая сможет дать новый толчок развитию экономики страны.

\section{Библиографические ссылки}

1. Aufbruch und Erneuerung - Deutschlands Weg ins 21. Jahrhundert. Koalitionsvereinbarung zwischen der Sozialdemokratischen Partei Deutschlands und BÜNDNIS 90/DIE GRÜNEN // gruene.de [Elektronische Quelle]. - 1998. - URL : http://www.gruene.de/fileadmin/user_upload/Bilder/ Redaktion/30_Jahre_-_Serie/Teil_21_Joschka_Fischer/Rot-Gruener_Koalitionsvertrag1998.pdf (Zugriffsdatum : 16.03.2015).

2. Zeitreihen zur Entwicklung der erneuerbaren Energien in Deutschland // Bundesministerium für Wirtschaft und Energie [Elektronische Quelle]. - 2015. - URL : http://www.erneuerbareenergien.de/EE/Navigation/DE/Service/Erneuerbare_Energien_in_Zahlen/Zeitreihen/zeitreihen. html (Zugriffsdatum : 21.05.2015).

3. Gesetz für den Vorrang Erneuerbarer Energien (Erneuerbare-Energien-Gesetz - EEG) sowie zur Änderung des Energiewirtschaftsgesetzes und des Mineralölsteuergesetzes // Bundesgesetzblatt [Elektronische Quelle]. - 2000. - URL : http://www.bgbl.de/banzxaver/bgbl/start.xav?startbk= Bundesanzeiger_BGBl\&jumpTo=bgbl100s0305.pdf\#_bgbl_\%2F\%2F*[\%40attr_id\%3D\%27 bgbl100s0305.pdf\%27]_1426521585801 (Zugriffsdatum : 16.03.2015).

4. Erzeugung. Aufkommen von Gasen // Statistisches Bundesamt [Elektronische Quelle]. - 2015. URL : https://www.destatis.de/DE/ZahlenFakten/Wirtschaftsbereiche/Energie/Erzeugung/Tabellen/ AufkommenGas.html (Zugriffsdatum : 03.05.2015).

5. «Selbstverständlich haben die sowjetischen Truppen Deutschland vom Nationalsozialismus befreit» - «Die Erinnerung an den Krieg ist Teil unserer nationalen Identität» // AG Friedensforschung [Elektronische Quelle]. - 2005. - URL : http://www.ag-friedensforschung.de/ themen/Befreiung/schroeder-putin.html (Zugriffsdatum : 03.05.2015).

6. Германия. Вызовы XXI века / под ред. В. Б. Белова. - М. : Весь мир, 2009.

7. Gemeinsam für Deutschland. Mit Mut und Menschlichkeit. Koalitionsvertrag von CDU, CSU und SPD // Christlich Demokratische Union Deutschlands [Elektronische Quelle]. - 2005. - URL : http://www.cdu.de/system/tdf/media/dokumente/05_11_11_Koalitionsvertrag_Langfassung_navigi erbar_0.pdf?file $=1 \&$ type $=$ node $\& i d=1100($ Zugriffsdatum $:$ 01.04.2015). 
8. Проект газопровода «Северный поток»: за и против // РИА Новости [Электронный реcypc]. - 2009. - URL : http://ria.ru/business/20090605/173415523.html (дата обращения : 04.04.2015).

9. Белоруссия предложила себя «Газпрому» // Издательский дом Коммерсантъ [Электронный ресурс]. - 2007. - URL : http://www.kommersant.ru/doc/815078 (дата обращения : 04.04.2015).

10. Merkel in Moscow: Don't Get too Excited about Medvedev, Putin Warns // SPIEGEL ONLINE [Electronic resource]. - 2008. - URL : http://www.spiegel.de/international/world/merkel-inmoscow-don-t-get-too-excited-about-medvedev-putin-warns-a-540313.html (date of access : 03.05.2015).

11. South Stream: Германия // South Stream [Электронный ресурс]. - 2015. - URL : http://www.south-stream.info/ru/partners/germany/newscat/49/ (дата обращения : 07.04.2015).

12. Energiekonzept für eine umweltschonende, zuverlässige und bezahlbare Energieversorgung // Bundesregierung [Elektronische Quelle]. - 2010. - URL: http://www.bundesregierung.de/ ContentArchiv/DE/Archiv17/_Anlagen/2012/02/energiekonzept-final.pdf?_blob=publicationFile $\& v=5$. (Zugriffsdatum: 02.05.2015).

13. France Criticizes German Retreat from Nuclear on Emissions // Bloomberg Business [Electronic resource]. - 2011. - URL : http://www.bloomberg.com/news/articles/2011-05-30/areva-slauvergeon-says-germany-will-import-nuclear-power (date of access : 02.05.2015).

14. Rede von Bundeskanzlerin Angela Merkel anlässlich der Inbetriebnahme der Nord StreamPipeline // Bundesregierung [Elektronische Quelle]. - 2011. - URL : http://www.bundesregierung. de/ContentArchiv/DE/Archiv17/Reden/2011/11/2011-11-08-merkel-lubmin.html (Zugriffsdatum : 30.04.2015).

15. Rösler: Nord Stream ist europäisches Projekt // Bundesregierung [Elektronische Quelle]. 2011. - URL : http://www.bundesregierung.de/ContentArchiv/DE/Archiv17/Interview/2011/11/ 2011-11-08-roesler-welt.html (Zugriffsdatum : 30.04.2015).

16. Nord Stream. The new gas supply route for Europe // Nord Stream AG [Electronic resource]. 2015. - URL : https://www.nord-stream.com/ (date of access : 18.03.2015).

17. Europäische Energieunion // Bundesregierung [Elektronische Quelle]. - 2015. - URL : http://www.bundesregierung.de/Content/DE/Artikel/2015/03/2015-03-23-energieunion.html (Zugriffsdatum : 05.05.2015).

18. Energieaußenpolitik // Auswärtiges Amt [Elektronische Quelle]. - 2014. - URL : http://www.auswaertiges-amt.de/DE/Aussenpolitik/GlobaleFragen/Energie/Energieau\%C3\%9Fen politik_node.html (Zugriffsdatum : 05.05.2015).

19. NordLink : Grünes Licht für Seekabel zwischen Deutschland und Norwegen // Bundesministerium für Wirtschaft und Energie [Elektronische Quelle]. - 2015. - URL : http://www.bmwi.de/DE/Themen/energie,did=689608.html (Zugriffsdatum : 06.05.2015).

\section{Международные аспекты энергетической политики ФРГ в начале ХХІ века (Екатерина Гартунг)}

Исследуются международные аспекты энергетической политики ФРГ с 1998 по 2015 г. Германия, будучи четвертой страной в мире по величине ВВП, седьмой по уровню потребления первичной и шестой - электроэнергии, получает 63 \% потребляемой энергии извне, что говорит о высокой зависимости страны от импорта энергоносителей. 
Определены концептуальные основы энергетической политики ФРГ и причины изменения этой политики в изучаемый период. Развитие внешней энергетической политики Германии рассматривается в связи со сменами правящих коалиций и изменением подходов к реализации энергетической политики ФРГ.

\section{Ключевые слова}

Федеративная Республика Германия; энергетическая политика; «энергетический поворот»; «Северный поток»; возобновляемые источники энергии; энергетическое партнерство; Энергетический союз ЕС.

\section{International aspects of the energy policy of the Federal Republic of Germany in the beginning of the 21st century (Ekaterina Gartung)}

The article studies the international aspects of energy policy of the Federal Republic of Germany in 1998-2015. Germany, being the fourth country in the world in terms of GDP, the seventh in primary energy consumption and the sixth in energy consumption, gets $63 \%$ of the energy from the outside, indicating that Germany is highly dependent on energy imports.

The conceptual foundations of Germany's energy policy and the reasons for the change of this policy in the studied period are defined in the article. The development of the external energy policy in Germany is considered in connection with the shifts of ruling coalitions and changing approaches to the implementation of Germany's energy policy.

\section{Key words}

Federal Republic of Germany; energy policy; «energy transition»; «Nord Stream»; renewable energy sources; energy partnership; Energy Union of the EU.

Статья поступила в августе 2015 г.

\section{Рецензенты:}

Шарапо А. В. - доктор исторических наук, профессор кафедры международных отношений факультета международных отношений Белорусского государственного университета;

Есин Р. О. - доктор политических наук, профессор кафедры международных отношений Академии управления при Президенте Республики Беларусь. 


\section{«ОДИН ПОЯС - ОДИН ПУТЬ» В ОТНОШЕНИЯХ \\ КИТАЙСКОЙ НАРОДНОЙ РЕСПУБЛИКИ \\ И РЕСПУБЛИКИ БЕЛАРУСЬ}

\section{Го Цзиньлун}

соискатель кафедры международных отномений

факультета международных отношений

Белорусского государственного университета

УДК 327(510:476)

Ключевые понятия китайской дипломатии в 2015 г. - один центр тяжести и две основные линии. Один центр тяжести - «Один пояс, один путь». Две основные линии - мир и развитие.

Лозунг «Один пояс - один путь» определяет приоритет китайской внешней политики в 2015 г. Китайская дипломатия в 2015 г. намерена сосредоточить усилия на достижении всестороннего прогресса в строительстве Экономического пояса Шелкового пути и Морского шелкового пути XXI в., что отражено в лозунге «Один пояс - один путь» [2].

Об этом в ходе третьей сессии Всекитайского собрания народных представителей 12-го созыва заявил Ван И, министр иностранных дел КНР. Китай намерен и дальше активизировать контакты с другими странами в плане соответствующих политических установок, искать новые точки соприкосновения интересов и возможные средства для взаимовыгодного сотрудничества.

Более 2 тыс. лет назад народы Евразийского континента открыли несколько путей торговли и сообщения, которые связали цивилизации Азии, Европы и Африки. Впоследствии их назвали Великим шелковым путем. Веками из поколения в поколение передавались основные ценности Великого шелкового пути - «мир и сотрудничество, открытость и толерантность, взаимное заимствование и обмен опытом, взаимная выгода и общий выигрыш». Этот путь способствовал прогрессу человеческой цивилизации в целом, развитию и процветанию близлежащих к нему стран в частности. Великий шелковый путь - символ общения Востока и Запада, он - общее историческое и культурное наследие всех стран мира. В XXI в., в эпоху мира, развития, сотрудничества и общего выигрыша, на фоне медленного про- 
цесса восстановления мировой экономики, сложной международной и региональной обстановки, особенно важно и актуально продолжать и развивать основную ценность Великого шелкового пути.

В сентябре - октябре 2013 г. председатель КНР Си Цзиньпин во время визитов в страны Центральной и Юго-Восточной Азии выдвинул инициативу по совместному созданию Экономического пояса Шелкового пути и Морского шелкового пути XXI в., что привлекло внимание международного сообщества. Премьер Госсовета КНР Ли Кэцян на выставке «Китай - АСЕАН» подчеркнул, что необходимо формировать Морской шелковый путь с участием стран АСЕАН и создавать стратегические опорные пункты для развития внутренних регионов.

Скорейшее создание «Одного пояса - одного пути» будет способствовать экономическому процветанию стран вдоль Великого шелкового пути и экономическому сотрудничеству в регионе, содействовать обмену и контактам между разными цивилизациями, благоприятствовать мирному развитию на планете. Словом, дело «Одного пояса - одного пути» - это великое дело на благо народов всех стран мира [5].

Цель данного исследования - оценка реализации проекта «Один пояс - один путь» для определения дальнейших путей развития сотрудничества Китая и Беларуси.

Объект исследования - реализация проекта «Однин пояс - один путь» в качестве дипломатической стратегии Китая.

Предмет исследования - состояние и перспективы развития отношений Китая и Беларуси в обстановке реализации проекта «Один пояс - один путь».

Источниковедческую базу исследования составляют официальные документы и материалы, в первую очередь двусторонние договоры и соглашения [7], воспоминания государственных деятелей Китая и Беларуси $[1 ; 5 ; 6 ; 8]$. Особый интерес представляют официальные материалы МИД КНР [2].

Современный мир переживает глубокие и сложные изменения. Мировой финансовый кризис продолжает давать о себе знать глубинным влиянием на все сферы жизни, мировая экономика восстанавливается медленно и в своем развитии не единонаправлена. Большие изменения вынашиваются в международной торгово-инвестиционной структуре и в правилах многосторонних инвестиций и тор- 
говли. В такой ситуации страны по отдельности сталкиваются с серьезными проблемами в ходе развития.

Совместное создание «Одного пояса - одного пути» откликается на призыв современного мира к многополярности, глобализации экономики, культурному многообразию и информатизации общества, а также к отстаиванию духа регионального сотрудничества открытого типа, общей для всего мира системы свободной торговли и открытости мировой экономики.

Совместная реализация проекта «Однин - пояс - однин путь» призвана стимулировать свободное, но упорядоченное передвижение факторов производства, высокоэффективное распределение ресурсов и глубокое влияние рынков. Проект даст возможность странам, расположенным вдоль Шелкового пути, скорректировать свою экономическую политику в сторону более масштабного, высокоуровневого и глубокого регионального сотрудничества, совместно сформировать структуру открытого, толерантного, сбалансированного и выгодного регионального экономического сотрудничества. Совместное создание «Одного пояса - одного пути» отвечает коренным интересам мирового сообщества, инициатива воплощает в себе мечту всех народов и их стремление к прекрасному.

Предлагаемый проект - это активные поиски новой модели международного сотрудничества и общемирового менеджмента, который, несомненно, послужит позитивной силой и энергией для мирного развития на всей планете. Инициатива «Один пояс - один путь» также нацелена на формирование и укрепление взаимосвязей в Азии, Европе и Африке, на укрепление взаимосвязанного партнерства между примыкающими к поясу и пути странами в интересах создания многовекторной, многоуровневой, комплексной сети сотрудничества, обеспечения стран, расположенных вдоль Шелкового пути, всесторонним, самостоятельным, сбалансированным и устойчивым развитием. Проекты взаимосвязи и интеграции помогут этим странам сверить и объединить стратегии развития, раскрыть потенциал регионального рынка, активизировать инвестиции и потребление, создать спрос и рабочие места, расширить гуманитарные обмены между народами и взаимообогащение культур. Это позволит народам разных стран чаще встречаться и больше познавать друг друга, что будет способствовать взаимодоверию и взаимоуважению, развитию гармонии, спокойствию и достатку. 
«Один пояс - один путь» - это путь, ведущий к совместному развитию, процветанию, сотрудничеству и обоюдному выигрышу. Это путь взаимопонимания и доверия, многовекторного взаимодействия, мира и дружбы. Инициатива китайского правительства базируется на идеях мира и сотрудничества, открытости и толерантности, взаимного заимствования и обмена опытом, взаимной выгоды и обоюдного выигрыша. Инициатива направлена на всестороннее деловое сотрудничество, призвана формировать сообщество интересов, судьбы и ответственности, для которого характерны политическое взаимодоверие, экономическая интеграция и культурная толерантность. «Один пояс - один путь» проходят страны Азии, Европы и Африки. С одного конца - активные экономики Восточной Азии, с другого - развитые экономики Европы, а между ними пролегают обширные земли государств с огромным потенциалом экономического развития.

Основные маршруты Экономического пояса Шелкового пути ведут из Китая через Центральную Азию, Россию в Европу, Балтийское море, из Китая через Центральную Азию и Западную Азию до Персидского залива и Средиземного моря, из Китая в Юго-Восточную Азию, в Южную Азию к Индийскому океану. Основные направления Морского шелкового пути XXI века: из морских портов Китая через Южно-Китайское море до Индийского океана и дальше до Европы, а также из китайских портов через Южно-Китайское море в южную акваторию Тихого океана.

В основных направлениях проекта «Один пояс - один путь» будет создаваться новый континентальный мост между Европой и Азией, а также международные коридоры экономического сотрудничества «Китай - Монголия - Россия», «Китай - Центральная Азия - Западная Азия» и «Китай - Индокитай». В их основу лягут крупные международные маршруты с опорными точками в ключевых городах и площадками для сотрудничества в важных торгово-экономикопроизводственных зонах.

На море будут создаваться безопасные, бесперебойные и высокоэффективные транспортные маршруты с узловыми точками в важнейших портах. Экономические коридоры «Китай - Пакистан» и «Бангладеш - Китай - Индия - Мьянма» тесно связаны с продвижением инициативы «Один пояс - один путь». Необходимо продвинуть сотрудничество между ними и достичь большего прогресса. 
Между странами вдоль Шелкового пути существует значительная разница в уровне обеспеченности природными ресурсами и в то же время большая экономическая взаимодополняемость, так что потенциал сотрудничества огромен. Основное содержание сотрудничества состоит из пяти пунктов: политическая координация, взаимосвязь инфраструктуры, бесперебойная торговля, свободное передвижение капитала и укрепление близости между народами.

В настоящее время ускоряется интеграция мировой экономики, региональное сотрудничество находится на подъеме. Используя действующие механизмы двустороннего и многостороннего сотрудничества, китайское правительство активно продвигает реализацию проекта «Один пояс - один путь», содействуя стремительному развитию регионального сотрудничества.

Сегодня как никогда актуальны укрепление двустороннего сотрудничества, развертывание контактов и консультаций на разных уровнях и по различным каналам, содействие всеобъемлющему развитию двусторонних отношений, продвижение программ взаимодействия, создание образцов взаимосотрудничества, создание и совершенствование двустороннего механизма совместной работы, разработка плана действия и дорожной карты по строительству «Одного пояса - одного пути». Необходимо в полной мере выявить роль существующих объединенных и смешанных комитетов, координационных, руководящих, управленческих комитетов, а также других двусторонних механизмов, координировать и направлять реализацию совместных проектов.

Необходимо укреплять роль и раскрывать преимущества таких многосторонних механизмов, как Шанхайская организация сотрудничества (ШОС), Китай - АСЕАН (формат «10+1»), Азиатско-Тихоокеанское экономическое сотрудничество (АТЭС), форум «Азия - Европа» (ACЕМ), Диалог по сотрудничеству в Азии (ДСА), Совещание по взаимодействию и мерам доверия в Азии (СВМДА), Форум китайскоарабского сотрудничества, диалог «Китай - Совет сотрудничества арабских государств Персидского залива» (Китай - ССАГПЗ), Экономическое сотрудничество субрегиона Большого Меконга (СБМ), Центрально-азиатское региональное экономическое сотрудничество (ЦАРЭС), а также развивать связи с соответствующими государствами, привлекать больше государств и регионов к участию в осуществлении инициативы «Один пояс - один путь». 
Проект «Один пояс - один путь» появился в век глобализации. Это результат открытости и сотрудничества, а не инструмент геополитики. Нельзя рассматривать эту инициативу в категориях времен холодной войны. Представление китайской инициативы «Один пояс один путь» как китайской версии Плана Маршалла демонстрирует незнание и скрытые намерения некоторых аналитиков. Инициатива «Один пояс - один путь» во многом отличается от американского Плана Маршалла, и любой серьезный экономист или политолог убедительно докажет, что такая аналогия надуманна.

Во-первых, разительны различия в мотивации. В отличие от политической направленности Плана Маршалла, который содействовал холодной войне, китайские инициативы не содержат политической подоплеки по интенсификации какой-либо конфронтации. Они выдвинуты Китаем с пониманием того, что многие развивающиеся страны стремятся к развитию без политических обязательств перед Западом, а также с уверенностью в том, что помощь им может принести выгоду Китаю.

Китай не намерен воспользоваться инициативами для формирования альянса против определенной страны или какой-либо группы стран. В соответствии с пятью принципами мирного сосуществования Китай не стремится установить господство в Азии и за ее пределами.

Выдвинув упомянутые инициативы, Китай стремится к укреплению общего развития вместо усиления антагонистических настроений.

Как указал председатель КНР Си Цзиньпин, инициативы создают огромную инклюзивную платформу для объединения быстро растущей китайской экономики с интересами вовлеченных стран. Если План Маршалла исключил коммунистические страны и обострил противостояние между Советским Союзом и Западом, то китайские инициативы «Один пояс - один путь» открыты для всех стран, которые хотят мира и развития, и не требуют выполнения каких-либо дополнительных условий.

Второе существенное отличие заключается в том, что инициативы «Один пояс - один путь» будут приняты совместно всеми вовлеченными странами и окажутся выгодными для всех сторон сотрудничества.

План Маршалла не только был решающим для восстановления западноевропейских стран после Второй мировой войны, но и помог 
Соединенным Штатам установить Бреттон-Вудскую валютную систему, основанную на долларе, которая практически гарантировала абсолютное доминирование американской валюты.

Однако подобное не является целью КНР. Как всегда, Китай призывает к многополярности и равноправным переговорам по всем международным вопросам.

Хотя Китай выделил большие средства для реализации этих инициатив и создал такие механизмы, как Азиатский банк инфраструктурных инвестиций и Фонд Шелкового пути, однако он не намерен навязывать свою волю другим странам.

Китай будет внимательным к другим сторонам проекта, обеспечит прозрачность и открытость, будет совмещать инициативы со стратегией развития других сторон, координировать их с региональными механизмами сотрудничества.

В-третьих, План Маршалла был в определенной степени чрезвычайным планом, который действовал примерно четыре года, а китайские инициативы «Один пояс - один путь» представляют долгосрочный проект, нацеленный на содействие интеграции международного сообщества, которое процветает в экономике и культуре.

Выдвинутая Китаем инициатива о создании Экономического пояса Шелкового пути и Морского шелкового пути XXI в. является не «соло», а «симфонией» всех заинтересованных сторон.

Беларусь находится в географическом центре Европы, это естественный и важный партнер по сотрудничеству в строительстве «пояса и пути». Участие в проекте Экономического пояса Шелкового пути может быть перспективным для Беларуси. Имея выгодное географическое положение, Беларусь будет обеспечивать северную ветку нового экономического Шелкового пути. Товары из Китая в Европу проходят через Беларусь, что служит для Беларуси веской причиной подключиться к новому проекту.

Беларусь имеет высокие перспективы участия в проекте нового экономического пояса. В интервью китайскому ежедневнику «Жэньминь жибао» премьер-министр М. Мясникович отмечал, что Минск «готов создать новые транспортные коридоры и логистические центры, способные полностью удовлетворить потребности нового Шелкового пути». При этом далеко не последнюю роль играет выгодное геополитическое расположение страны на перекрестке торговых путей между Россией и Европой [6]. 
Солидарен с мнением белорусского премьер-министра начальник управления по развитию и реформе Синьцзян-Уйгурского автономного района Китая Чжан Чуньлинь. Он подчеркнул, что в последнее время транспортное сообщение между Беларусью и КНР значительно улучшилось. Например, 40-дневные морские транспортировки успешно замещены 15-дневными железнодорожными перевозками, что в свою очередь положительно отразилось и на ценовой политике товарообмена [8].

Для китайской прессы белорусская магистраль - один из пунктов масштабного автомобильного медиапробега под названием «Новый Шелковый путь». Вдоль всего маршрута следования контейнерного поезда из Китая через Казахстан и Россию у белорусской магистрали особое место. В Бресте контейнерный состав перегружают на более узкую европейскую колею. Современные технологии позволяют сделать это в оптимальные для клиента сроки. Обработка поездов в Брестском узле контейнеров и любых других грузов осуществляется за 12 часов и включает как перегруз, так и переоформление таможенных документов. Контейнерный маршрут из Чунцин в Дуйсбург один из наиболее оптимальных и выгодных. Из Китая до Западной Европы товар доходит примерно за 14 суток. Аналогичная доставка по морю занимает от 35 до 50 суток. У белорусской магистрали очень высокий уровень логистической инфраструктуры, профессионально работают и белорусские менеджеры. Контейнерные перевозки «Восток - Запад - Восток» транзитом через Беларусь имеют большие преимущества как для Востока, так и для Запада. У белорусской магистрали будет важная роль связующего звена между Востоком и Западом [4].

Также представляет интерес туристический маршрут «Великий шелковый путь». В него войдут 19 городов из разных стран мира, расположенных вдоль древнего торгового пути. 15 июня 2014 г. 19 городов подписали соглашение о разработке совместного туристического маршрута «Великий шелковый путь». Соглашение подписано в ходе 4-го одноименного международного туристического фестиваля, который начался в китайском городе Чжанъе, расположенном в северо-западной провинции Ганьсу. Туристический маршрут «Великий шелковый путь» пройдет через китайские провинции Шэньси, Ганьсу, Нинся, Цинхай, Внутренняя Монголия, Синьцзян и Тайвань, а также Беларусь, Украину, Бахрейн, Кипр, Казахстан, Кыргызстан, 
Саудовскую Аравию, Малайзию и Непал. В 2014 г. в 19-ти городах состоится ряд туристических форумов и выставок. Туристический проект «Великий шелковый путь» позволит наладить более тесные и дружественные отношения между Китаем и странами, расположенными вдоль древнего торгового пути, связывавшего Китай и Европу во II в. до н. э. [7].

Проект «Великий камень» (Китайско-белорусский индустриальный парк) представляет узловую платформу инициативы Экономического пояса Шелкового пути. Это пилотный проект, представляющий важность в контексте двустороннего сотрудничества и строительства Экономического пояса Шелкового пути.

Китайско-белорусский индустриальный парк представляет собой территориальное образование площадью около 80 кв. км с особым правовым режимом для обеспечения комфортных условий ведения бизнеса. Парк расположен в 25 км от Минска в уникальном природном комплексе и в непосредственной близости от международного аэропорта, железнодорожных путей, транснациональной автомобильной магистрали Берлин - Москва. На территории парка планируется разместить производственные и жилые зоны, офисные и торгово-развлекательные комплексы, финансовый и научно-исследовательский центры. Фактически строится современный международный экогород с акцентом на высокотехнологичные и конкурентоспособные инновационные производства с высоким экспортным потенциалом. Проект развивается в рамках межгосударственного китайскобелорусского сотрудничества и подписанных соответствующих межправительственных документов. В качестве резидентов индустриального парка могут выступать любые компании, независимо от страны происхождения капитала [3].

Понимая остроту борьбы за инвестора на мировом рынке, Беларусь создала благоприятный инвестиционный климат для резидентов индустриального парка, гарантированный как национальным законодательством, так и специальными международными соглашениями и обязательствами, предоставила беспрецедентные льготы и преференции, образовала отдельный независимый орган государственного управления, осуществляющий комплексное административное обслуживание по принципу «одного окна». Кроме того, индустриальный парк готов предложить инженерную и транспортную инфраструктуру, обеспечиваемую управляющей компанией, широкие воз- 
можности 170-миллионного беспошлинного рынка стран Таможенного союза Беларуси, России и Казахстана, а также соседних европейских стран, удобное географическое расположение, оптимизирующее временные и транспортные издержки, дисциплинированные и квалифицированные кадры белорусского рынка труда [3].

Президент Беларуси А. Лукашенко назвал Китайско-белорусский индустриальный парк самым важным совместным проектом страны. По его мнению, проект снимет проблему финансовой стабильности Беларуси и поможет стране совершить технологический скачок [1].

За 22 года дипломатических отношений между Китаем и Беларусью динамика двустороннего сотрудничества достигла таких результатов, что может считаться образцом для других государств.

Формирование Экономического пояса Шелкового пути углубит китайско-белорусское сотрудничество, предоставит больше возможностей бурно развивающимся отношениям между Китаем и Беларусью, создаст движущие силы для всестороннего углубления сотрудничества.

В целом проект «Новый Шелковый путь» ориентирован на долгосрочную перспективу - его реализация может потребовать 30 лет. Он способен охватить порядка 40 стран с общей численностью жителей более 3 млрд человек. Все вышеперечисленное свидетельствует о масштабности самого проекта и перспектив, которые он открывает перед Беларусью.

Реализация проекта «Один пояс - один путь» - это не только инициатива Китая, но и общее стремление Китая и всех других стран, расположенных на этом пути. Стоящие на новом старте Китай и другие государства вдоль «пояса и пути» имеют возможность совместного создания «Одного пояса - одного пути», могут провести равноправные консультации с учетом интересов всех сторон, сообща продвигать более широкую, качественную, многоуровневую коммуникацию, открытость, интеграцию.

Строительство «Одного пояса - одного пути» - это открытый процесс. Основой совместного строительства «Одного пояса - одного пути» служат координация основных задач и сближение политических мероприятий. Добиваться единства во всем нет необходимости, допускается высокая степень мобильности, гибкости, поскольку речь идет о многообразном открытом процессе сотрудничества. Китай 
вместе с другими государствами вдоль «пояса и пути» должен непрерывно обогащать и совершенствовать содержание и методы сотрудничества по проекту «Один пояс - один путь», совместно определять временные рамки, дорожную карту, согласовывать планы национального развития стран вдоль «пояса и пути» и регионального сотрудничества. Страны, расположенные по этому пути, в рамках действующих дву- и многосторонних механизмов регионального и субрегионального сотрудничества в различных формах взаимодействия (в том числе совместное исследование, проведение форумов и выставок, подготовка кадров, обмены и взаимные визиты) должны содействовать пониманию и одобрению всеми государствами сути, целей и задач проекта «Один пояс - один путь».

Инициатива «Один пояс - один путь» - это путь взаимного уважения и взаимодоверия, путь сотрудничества и общей выгоды, путь межцивилизационного взаимозаимствования. Если все государства, расположенные вдоль Шелкового пути, будут сотрудничать и идти навстречу друг другу, то в историю Экономического пояса Шелкового пути и Морского шелкового пути XXI века будет вписана качественно новая страница, а результаты проекта станут общим благом народов стран вдоль «Одного пояса - одного пути».

\section{Библиографические ссылки}

1. Бай э ло сы цзун тун дуй чжун бай гун е юнь чун ман ци дай = Президент Беларуси заявил, что возлагает большие надежды на проект по созданию Китайско-белорусского индустриального парка // Агентство «Синьхуа» [Электронный ресурс]. - 2013. - URL : http://news. xinhuanet.com/world/2013-07/27/c_125074171.htm (дата обращения : 19.02.2015. (на кит. яз.)

2. Вай цзяо бу чжан Ван И цзю чжун го вай цзяо чжэн цэ хэ дуй вай гуань си да чжун вай цзи чжэ вэнь = Министр МИД КНР Ван И отвечает на вопросы журналистов по внешней политике Китая // МИД КНР [Электронный ресурс]. - 2015. - URL : http://www.fmprc.gov.cn/mfa chn/zyxw_602251/t1135388.shtml (дата обращения : 08.03.2015). (на кит. яз.)

3. Общая информация Китайско-белорусского индустриального парка // Китайско-белорусский индустриальный парк [Электронный ресурс]. - 2013. - URL : http://www.industrial park.by/about/ (дата обращения : 06.04.2015).

4. Оу я те лу юнь шу = Евразийский железнодорожный транспорт // Шанхайская морская биржа [Электронный ресурс]. - 2012. - URL: http://www.sse.net.cn/info/0-31029411325118222219315663.html (дата обращения : 15.01.2015). (на кит. яз.)

5. Си Цзиньпин ти и дай и лу чжань люе гоу сян = Си Цзиньпин предложил создать «Один пояс и один путь» // Агентство «Синьхуа» [Электронный ресурс]. - 2014. - URL: http://news. 
xinhuanet.com/fortune/2014-08/11/c_1112013039.htm (дата обращения : 23.10.2014) (на кит. яз.)

6. Си Цзиньпин хуэй цзянь бай э ло сы цзун ли = Си Цзиньпин встретился с премьерминистром Республики Беларусь // Агентство «Народ» [Электронный ресурс]. - 2014. - URL: http://politics.people.com.cn/n/2014/0122/c1024-24188162.html (дата обращения : 28.01.2014) (на кит. яз.)

7. Чжун вай 19 чэн ши цзянь сы чоу чжи лу люй ю цзин цзи ти $=19$ городов из разных стран мира подписали соглашение о разработке совместного туристического маршрута «Великий Шелковый путь» // Агентство «Синьхуа» [Электронный ресурс]. - 2014. - URL : http://news. xinhuanet.com/world/2014-06/15/c_1111150157.htm (дата обращения : 17.03.2015) (на кит. яз.)

8. Чжуань фан синь цзян фа гай вэй чжу жэнь чжан чунь линь = Интервью начальника управления по развитию и реформе Синьцзян-Уйгурского автономного района Китая Чжан Чуньлинь // Информационное бюро Госсовета КНР [Электронный ресурс]. - 2014. - URL : http://www.scio.gov.cn/ztk/dtzt/2014/31055/31062/Document/1373918/1373918.htm (дата обращения : 15.07.2014) (на кит. яз.)

«Один пояс - один путь» в отночениях Китайской Народной Республики и Республики Беларусь (Го Цзиньлун)

Анализируется проект «Один пояс - один путь» в качестве дипломатической стратегии Китая для определения дальнейших путей развития Китая и Беларуси. Описаны состояние и перспективы развития отношений Китая и Беларуси в условиях реализации этого проекта. В результате проведенного анализа сделан вывод о том, что формирование Экономического пояса Шелкового пути будет содействовать углублению китайско-белорусского сотрудничества, способствовать бурно развивающимся отношениям между Китаем и Беларусью, создаст еще больше движущих сил для углубления сотрудничества между сторонами.

\section{Ключевые слова}

Китай; Беларусь; Экономический пояс Шелкового пути; План Маршалла; китайско-белорусская торговля; китайско-белорусский индустриальный парк.

«One belt - one way» in relations between the People's Republic of China and Repablic of Belarus» (Guo Jinlong)

This article analyzes the creation of «One belt - one way» as China's diplomatic strategy and its implementation to determine further ways of cooperation between China and Belarus. The analysis concluded that the 
formation of an «Economic belt of the Silk Road» will help to deepen the Chinese-Belarusian cooperation, to provide more opportunities for developing relations between China and Belarus, to create even greater driving force for the comprehensive cooperation between the parties.

\section{Key words}

China; Belarus; the Economic belt of the Silk Road; Marshall Plan; China-Belarus trade; Chinese-Belarusian industrial park.

Статья поступила в апреле 2015 г.

\section{Рецензенты:}

Байчоров А. М. - доктор философских наук, профессор Белорусского государственного университета;

Ватыль В. Н. - доктор политических наук, профессор, заведующий кафедрой политологии Гродненского государственного университета имени Янки Купалы. 


\section{ВЫЗОВЫ ПЕРСОНАЛИЗАЦИИ ГОСУДАРСТВЕННЫХ УСЛУГ В ЛИТВЕ: ВОЗМОЖНОСТИ И ОГРАНИЧЕНИЯ}

\section{Я. Н. Дворак}

заведующий кафедрой государственного управления и права

Клайпедского университета, доиент

C. А. Савицкайте

магистрант Клайпедского университета

УДК $338.46(474.5)$

Теоретически основная цель предоставления государственных услуг - стремление сделать их как можно лучше, качественнее, достигнуть наивысшей эффективности, ориентируясь на нужды граждан (потребителей). Удовлетворенность предоставленной услугой напрямую зависит от ее качества. Обычно государственные услуги предоставляет монопольный поставщик. Здесь государственный сектор встречается с проблемой выбора, которая очень важна при анализе возможности персонализации государственных услуг.

Несомненно, возможность выбора улучшает качество жизни граждан и позволяет самим управлять будущим. Выбор очень важен для создания автономии. К. Фреу [2] утверждает, что расширение выбора меняет отношения между потребителем услуги и самой услугой. Принято считать, что, когда индивиду предоставляется право выбора, он становится более мотивированным, и это помогает улучшить результат его деятельности. Хотя не стоит забывать, что предоставленная свобода выбора сопряжена с реализацией личного контроля и принятием ответственности. Позитивная сторона выбора проявляется в повышении уровня доверия, формировании новых навыков, самостоятельности, мотивации и т. д. Следует подчеркнуть, что все преимущества, предоставляемые выбором, и их «качественное» проявление зависят от того, насколько индивид намерен проявить себя и какой уровень персонализации достигнут [5, с. 649].

Свобода выбора приносит не только положительные результаты. Распространение возможности выбора в государственном секторе поощряет процессы индивидуализации и вызывает некоторые риски, особенно связанные с принятием ответственности. Риск и ответст-

\footnotetext{
* С. А. Савицкайте благодарит Литовский совет науки за оказанную поддержку.
} 
венность становятся важными вызовами свободы выбора [2, с. 6]. Когда человеку предоставляется возможность выбора, он из-за своего ограниченного знания, недостатка компетенции рискует совершить ошибку. За последствия такого выбора будет отвечать не кто иной, как сам человек. Если выбор является навязанным или не обоснованным надежной информацией, он может принести больше убытка, чем пользы. С возрастанием важности решения увеличивается и риск.

В странах Европейского союза, например в Великобритании, нововведения в сфере предоставления государственных услуг определяют вектор изменений, происходящих в системе предоставления, контроля и управления услугами. Паралельно меняются взгляд граждан на самих себя и принятые ими решения. Поэтому происходит «приватизация» социальной и экономической сфер жизни индивида.

Создание возможностей выбора поощряет инвестиции в себя. Приспособленный для граждан пакет государственных услуг, вместе с личным советником, позволяет людям самим оценивать предоставляемые услуги [2, с. 9]. Данные идеи похожи на доктрину копродукции государственных услуг, которая в 80-90-е гг. прошлого века стала альтернативой Новому государственному менеджменту ( $\mathrm{New}$ Public Management). Копродукция означает участие граждан в предоставлении государственных услуг - вместе с государственными служащими или самостоятельно (например, участие в работе дружин, сортировка мусора, инициативы за безопасное соседство). Важные черты копродукции - добровольность такой деятельности и необязательное соответствие правовым документам и правилам [1, с. 210].

\section{Что такое персонализация государственных услуг?}

К. Нидхам (2013) утверждает, что персонализация государственных услуг стала нормой. Анализ научной литературы позволяет констатировать, что общего понятия персонализации нет. Обычно ученые, характеризуя это явление, опираются на актуальные критерии и акценты. В определении персонализации можно выделить два преобладающих направления:

- персонализация объясняется с точки зрения политического, правового и управленческого подхода;

- акцент делается на психологический, ценностный подход.

К. Нидхам (2013) выделила пять нарративов персонализации:

- люди - эксперты своей жизни; 
- методы, ориентированные на людей, больше совпадают с их образом жизни, чем ограниченные знания государственных учреждений;

- персонализация подходит всем, не только нуждающимся в социальной помощи людям;

- смысл персонализации - сделать жизнь людей лучше;

- персонализация снижает затраты.

Персонализация предлагает совсем другой механизм предоставления государственных услуг. Люди получают широкий спектр услуг и возможность контролировать свою жизнь (сами идентифицируют потребности и выбирают услуги, которые им нужны). Эффективными методами выполнения такой политики служат личные бюджеты, прямые дотации, планирование помощи и т. д.

Для лучшего понимания персонализации можно выделить узкий и широкий подходы к ее определению. Результаты анализа правовых документов предоставлены в таблице 1 .

\section{Таблица 1. Понятие персонализации}

\begin{tabular}{|c|c|}
\hline \multicolumn{2}{|c|}{ Понятие персонализации } \\
\hline Узкий подход & Широкий подход \\
\hline $\begin{array}{l}\text { Персонализация - это обдумывание услуг } \\
\text { и того, кто ими пользуется, а не набор по- } \\
\text { литических «рецептов». } \\
\text { Персонализация - тема, объединяющая } \\
\text { всех, и доминирующая идея в Великобри- } \\
\text { тании в сфере предоставления государст- } \\
\text { венных услуг. }\end{array}$ & $\begin{array}{l}\text { Персонализация - это процесс, кото- } \\
\text { рый интегрирует разные компоненты. } \\
\text { Поэтому персонализацию понимаем } \\
\text { через такие явления, как: } \\
\text { • индивидуализация; } \\
\text { • декатегоризация; } \\
\text { • сравнение себя с другими; } \\
\text { • самооценка; } \\
\text { • эмпатия [7, с. 504] }\end{array}$ \\
\hline
\end{tabular}

Можно выделить следующие основные черты персонализации государственных услуг:

1. Поддержка должна быть адаптирована к индивидуальным потребностям человека.

2. Нужно гарантировать людям доступ к информации и адвокату.

3. Необходимо искать новые способы соотрудничества между разными сторонами, которые помогли бы людям активно включиться в процесс проектирования, предоставления и оценки услуг. 
4. Необходимо развивать местное партнерство, предлагая людям широкий спектр выбора и создавая возможности для социального участия.

5. Необходимо развивать лидерство и управленческие навыки, вспомогательное учебное окружение и организационные системы, где сотрудники могли бы работать в творческом, «смарт»окружении.

6. Нужно утвердить раннюю интервенцию, возможности защиты и превенции, чтобы люди получили квалифицированную помощь как можно раньше.

7. Необходимо гарантировать жителям доступ к универсальным услугам и ресурсам [4, с. 2].

Основным средством, используемым для реализации персонализации, является помощь, которой управляет ее получатель (Selfdirect support). Благодаря такой поддержке можно предоставлять персонализированные государственные услуги.

Для этого следует заключить договор между государством и гражданином. Благотворительная организация In Control для реализации персонализации советует использовать следующие формы персонализации:

- Личный бюджет. Это деньги, предоставляемые нуждающимся в помощи людям. Индивид, контролирующий бюджет, должен знать точную сумму помощи, а также уметь эффективно использовать средства и точно прогнозировать последствия.

- Прямые выплаты. Средства, выплачиваемые гражданину напрямую, с помощью которых он сам планирует помощь и услуги.

- Личный медицинский бюджет. Ресурсы распределяются на медицинские потребности человека. Планируя средства, нужно работать вместе с людьми, имеющими похожие потребности.

- Оценка поддержки. Консультируясь с профессионалами, важно наметить результаты. Местная власть как нейтральная сторона подтверждает результат оценки и план поддержки.

- Прямое распределение. Человек должен иметь ясные индикаторы, чтобы предвидеть, какая часть выделенных средств позволит ему достичь намеченных результатов.

- Планирование помощи. Создавая планы помощи, следует пользоваться советами и другой помощью. Планы не должны быть из- 
лишне детализированы, они должны показывать потребности человека и желаемые результаты.

- Выбор и контроль. Индивид решает, как будет управлять назначенным ему финансированием и как лучше истратить деньги, чтобы достичь желаемых результатов.

- Проверка. Местная власть должна проверять поставщиков услуг и определять, достигнуты ли оговоренные в планах результаты [4, c. 4-5].

Также персонализация государственных услуг способствует уменьшению дискриминации и гарантирует равные права. Обычно это касается таких маргинальных групп, как сексуальные меньшинства, люди, имеющие физические и умственные недостатки, этнические меньшинства, пенсионеры и люди с суицидальными наклонностями.

Анализ возможности персонализации психосоциальных услуг в правовых документах

Персонализация - сложный процесс, особенно с правовой точки зрения. Предоставление государственных услуг регламентируется государственными правовыми актами, поэтому диапазон свободы действий ограничен. Чтобы персонализация была эффективной, нужно подготовить правовую базу, которая создаст условия для предоставления персонализированных государственных услуг. Поэтому, изучая возможности персонализации психосоциальных услуг, важно рассмотреть основные правовые документы, регламентирующие предоставление медицинских услуг людям с онкологическими заболеваниями, и найти положения, близкие к персонализации. Так, при осуществлении персонализации предоставление услуг ориентируется на индивидуальные потребности индивида. При анализе правовых документов авторы руководствовались тремя критериями:

- развитие доступа $к$ психосочииальным услугам. Этот критерий означает, что пациенты должны быть обеспечены возможностями доступа к разнообразным психосоциальным услугам;

- расширение возможности выбора для пациента. Пациент и его близкие должны быть информированы об организациях, учреждениях, в которые можно обратиться для получения психосоциальных услуг. Таким образом пациент получает возможность сам выбрать подходящего поставщика услуг; 
- индивидуальное планирование медицинской помощи. В данном случае важно, консультируют ли специалисты пациентов, обсуждается ли дальнейшее лечение, учитывая здоровье пациента.

Результаты анализа правовых документов представлены в табл. 2. Таблица подготовлена в соответствии с законом Литовской Республики «О здравоохранении», Каталогом социальных услуг Литовской Республики, Программой здоровья Литвы на 2014-2021 гг., Национальной программой профилактики и контроля рака на 20142025 гг.

\section{Таблиц̧а 2. Проявления персонализации психосоциальных ус- луг в правовых актах Литвы}

\begin{tabular}{|c|c|c|}
\hline $\begin{array}{c}\text { Развитие доступа } \\
\text { к психосоциальным } \\
\text { услугам }\end{array}$ & $\begin{array}{c}\text { Расширение } \\
\text { возможностей выбора } \\
\text { для пациента }\end{array}$ & $\begin{array}{c}\text { Индивидуальное } \\
\text { планирование } \\
\text { медицинской помощи }\end{array}$ \\
\hline Возможности & $\mathrm{Bo}$ & Возможности \\
\hline $\begin{array}{l}\text { Планируется: } \\
\text { · увеличивать доступ к ме- } \\
\text { дицинским услугам, разви- } \\
\text { вая услуги психосоциальной } \\
\text { помощи для людей с онко- } \\
\text { логическими заболевания- } \\
\text { ми; } \\
\text { · признать и интегрировать } \\
\text { негосударственные органи- } \\
\text { зации как равноправных } \\
\text { партнеров, организующих } \\
\text { предоставление помощи } \\
\text { людям с онкологическими } \\
\text { заболеваниями; } \\
\text { - создать негосударствен- } \\
\text { ным организациям условия } \\
\text { для образовательной кон- } \\
\text { сультационной, психосоци- } \\
\text { альной помощи; } \\
\text { · ввести должность квали- } \\
\text { фицированного специалиста } \\
\text { в учреждении здравоохра- } \\
\text { нения }\end{array}$ & $\begin{array}{l}\text { - обеспечить тесное сотруд- } \\
\text { ничество специалистов } \\
\text { здравоохранения с него- } \\
\text { сударственными и общест- } \\
\text { венными организациями; } \\
\text { - применять инновационные } \\
\text { модели предоставления ус- } \\
\text { луг, в том числе него- } \\
\text { сударственными организа- } \\
\text { циями; } \text { - поддерживать программы, } \\
\text { выполняемые негосудар- } \\
\text { ственными организациями, } \\
\text { для людей с онкологи- } \\
\text { ческими заболеваниями, } \\
\text { ориентированные на улуч- } \\
\text { шение качества жизни }\end{array}$ & $\begin{array}{l}\text { - Пациенты имеют больше } \\
\text { прав, среди них право полу- } \\
\text { чить информацию о лече- } \\
\text { нии, условиях предостав- } \\
\text { ления медицинских услуг. } \\
\text { - Муниципалитет по по- } \\
\text { требности может предостав- } \\
\text { лять финансирование соци- } \\
\text { альных услуг. } \\
\text { · Намечен выпуск методи- } \\
\text { ческой литературы (психо- } \\
\text { социальная помощь). } \\
\text { - Планируется улучшать } \\
\text { качество обучения и повы- } \\
\text { шения квалификации спе- } \\
\text { циалистов здравоохранения. } \\
\text { - Намечено обучение людей } \\
\text { с онкологическими заболе- } \\
\text { ваниями и их родственни- } \\
\text { ков. } \\
\text { - В случае необходимости - } \\
\text { предоставление реабилита- } \\
\text { ции. } \\
\text { - Планируется подготовить } \\
\text { предоставление медицин- } \\
\text { ских услуг людям с онколо- } \\
\text { гическими заболеваниями }\end{array}$ \\
\hline
\end{tabular}




\begin{tabular}{|c|c|c|}
\hline Ограничения & Ограничения & Ограничения \\
\hline $\begin{array}{l}\text { - Отсутствие целевой груп- } \\
\text { пы людей с онкологическим } \\
\text { заболеванием среди получа- } \\
\text { телей психосоциальных ус- } \\
\text { луг. } \\
\text { - Люди с онкологическими } \\
\text { заболеваниями не принад- } \\
\text { лежат к группе риска. } \\
\text { · В системе здравоохране- } \\
\text { ния только намечается пре- } \\
\text { доставление психосоциаль- } \\
\text { ных услуг людям с онколо- } \\
\text { гическими заболеваниями. } \\
\text { - Государство не планирует } \\
\text { содействие в подготовке } \\
\text { добровольцев для оказания } \\
\text { помощи и слабо поощряет } \\
\text { добровольчество }\end{array}$ & $\begin{array}{l}\text { · Не детализированы спосо- } \\
\text { бы сотрудничества. } \\
\text { · Критерии проектного фи- } \\
\text { нансирования тяжело адап- } \\
\text { тируются негосударствен- } \\
\text { ными организациями. } \\
\text { · Нет информации о том, } \\
\text { куда могли бы обратиться } \\
\text { пациенты для получения } \\
\text { психосоциальных услуг }\end{array}$ & $\begin{array}{l}\text { - Для людей с онкологиче- } \\
\text { скими заболеваниями не го- } \\
\text { товы целевые выплаты и } \\
\text { другая финансовая помощь. } \\
\text { - Не ясна роль муниципали- } \\
\text { тетов в предоставлении ус- } \\
\text { луг людям с онкологиче- } \\
\text { скими заболеваниями. } \\
\text { - В правовых документах не } \\
\text { детализируются права лю- } \\
\text { дей с онкологическими за- } \\
\text { болеваниями и возможность } \\
\text { выбора медицинских услуг. } \\
\text { - Не планируется психосо- } \\
\text { циальная помощь для людей } \\
\text { с онкологическими заболе- } \\
\text { ваниями }\end{array}$ \\
\hline
\end{tabular}

Как видно из таблицы, в Литве существует немало инструментов, которые по своему содержанию близки к персонализации, но в данном случае они фрагментированы и не подготовлены к предоставлению психосоциальных услуг людям с онкологическими заболеваниями. Основная причина кроется в том, что психосоциальные услуги все еще не интегрированы в систему здравоохранения Литвы.

Анализ данных позволяет сформировать теоретический координационный механизм предоставления психосоциальных услуг в Литве. Этот механизм показывает, как можно персонализировать психосоциальные услуги в данной ситуации в соответствии с институционной структурой и правовой базой.

За формирование программы персонализации психосоциальных услуг ответственны два министерства - здравоохранения и социальной защиты и труда. Оба министерства в случае разработки программы по персонализации должны будут отвечать за подготовку соответствующей правовой базы и сотрудничество с представителями организаций, защищающих права пациентов. За выполнение персонализации ответственность должны нести муниципалитеты, специализированные медицинские учреждения и негосударственные организации. Эти заинтересованные стороны должны активно сотрудничать. 


\section{Библиографические ссылки}

1. Dvorak J. Valstybės ir piliečių kodalyvavimas viešujų paslaugu sferoje // Pilietinė visuomenė: politikos ipilietinimo projekcijos. - Klaipèda : Klaipėdos Universiteto leidykla.

2. Frew C. Making «Choices» in Home Care. What will an increased «choice» mean for employment and servise provision? // depts.washington [Electronic resource] - URL : http://depts. washington.edu/pcls/caringlaborconference/frewpaper.pdf. - 2005 (date of access: 14.04.2015).

3. Needham C. Personalization: From day centres to community hubs? // Critical Social Policy. 2014. - № 34 (1). - P. 90-108.

4. SCIE - Social Care Institute for Excellence (2012). Personalisation : a rough guide // scie.org [Electronic resource] - URL : http://www.scie.org.uk/publications/guides/guide47/ files/guide47.pdf (date of access: 14. 04.2015).

5. Putting oneself in the task : choice, personalization, and confidence / R. W. Tafarodi [at all] // University of Toronto. [Electronic resource] - 2002. - URL : http://www.psych.utoronto.ca/ users/tafarodi/Papers/PSPB02b.pdf (date of access: 14. 04.2015).

6. The personalization model revisited: An experimental investigation of the role of five personalization-based strategies on prejudice reduction / N. Ensari [at all]// Group Processes \& Intergroup Relations. - 2012. - № 15(4). - P. 503-522.

7. LR Socialiniu paslaugu katalogas // E-tar.lt [Electronic resource]. - 2006. - URL : https://www.e-tar.lt/portal/lt/legalAct/TAR.51F78AE58AC5. (date of access : 14. 04.2015).

8. Lietuvos sveikatos 2014-2021 m. Programa (Sveikatos sektoriaus plètros programa) // Hi.lt [Electronic resource]. - 2013. - URL : http://www.hi.lt/uploads/pdf/projektai/VS\%20pletros\% 20strategijos/1.1.2\%20STUDIJA_LT.pdf (date of access : 14. 04.2015).

9. Nacionalinès vèžio profilaktikos ir kontrolès 2014-2025 m. programos igyvendinimo priemonių 2014-2016 m. planas // E-tar.lt [Electronic resource]. - 2014. - URL : https://www.etar.lt/portal/lt/legalAct/4e5e6800770111e49710918558376243 (date of access : 14. 04.2015).

10. Nacionalinė vėžio profilaktikos ir kontrolès 2014-2025 m. programa // E-tar.lt [Electronic resource]. - URL : https://www.e-tar.1t/portal/lt/legalAct/051d0e500ce211e4adf3c8c5d7681e73 (date of access : 14. 04.2015).

Вызовы персонализации государственных услуг в Литве: возможсности и ограничения (Ярослав Дворак, Саманта Савицкайте)

Персонализация государственных услуг широко распространена в Великобритании, особенно в сфере здравоохранения. Формирование личных бюджетов создает лучшие условия для предоставления медицинских, образовательных и других услуг, так как в этом случае граждане могут выбирать медицинские услуги по потребности.

В статье оцениваются возможности предоставления персонализированной психосоциальной услуги людям с онкологическими заболеваниями и конструируется теоретический механизм персонализации данной услуги в Литве. 


\section{Ключевые слова}

Персонализация; государственные услуги; выбор; Литва; Великобритания.

Challenges in personalization of public services in Lithuania: possibilities and limitations (Jaroslav Dvorak, Samanta Savickaitè)

The personalization of public services are broadly developed in Great Britain. Obvious evidence comes from the medicine sector. The formation of personal budgets create better conditions for the delivery of medicine, educative and other services, because the citizens choose the services according to their needs. In the article we assess the feasibilities for the delivery of personalized psichosocial services for patients with cancer. Also we constructed a theoretical personalization mechanism for this type of service in Lithuania.

\section{Key words}

Personalization; public services; choice; Lithuania; Great Britain.

Статья поступила в сентябре 2015 г.

\section{Рецензенты:}

Решетников С. В. - доктор политических наук, профессор, заведующий кафедрой политологии Белорусского государственного университета;

Малевич Ю. И. - доктор политических наук, профессор кафедры международных отношений Белорусского государственного университета. 


\section{МЕЖДУНАРОДНОЕ СОТРУДНИЧЕСТВО \\ В СФЕРЕ ВЫСШЕГО ОБРАЗОВАНИЯ}

(СЕТЕВАЯ ОРГАНИЗАЦИЯ ДЕЯТЕЛЬНОСТИ)

\section{В. В. Добровольская}

соискатель кафедры международных отношений

Белорусского государственного университета

УДК 378.014 .24

Международное сотрудничество в высшем образовании является признанным примером «мягкой силы» в достижении внешнеполитических задач государства, поскольку демонстрирует как развитие экономики и политической системы страны, так и уровень ее национальной безопасности.

Развитие такого сотрудничества направлено на «экспорт» национальных культурных, гуманитарных ценностей, демонстрирует качество человеческого капитала страны. Международное сотрудничество в высшем образовании способствует достижению целей по «равноправной интеграции» нашей страны в мировое научное пространство, «созданию благоприятных внешнеполитических и внешнеэкономических условий для повышения уровня благосостояния народа, развития политического, экономического, интеллектуального и духовного потенциала государства ... привлечению внешних интеллектуальных и научных ресурсов в интересах образовательного, научного и культурного развития Республики Беларусь» [1].

Цель данной статьи - выявление основных направлений и форм международного сотрудничества в высшем образовании, изучение примеров сетевых взаимодействий для последующего определения их эффективности.

Достижению заявленной цели способствовало изучение статистических, аналитических и информационных материалов, трудов отечественных и зарубежных ученых, нормативно-правовых актов.

На современном этапе межвузовское сотрудничество - как дву-, так и многостороннее - рассматривается в трудах Б. Ж. Абраимова [8], Е. А. Неретиной [11] в качестве одного из ключевых факторов развития общего образовательного пространства, основы динамичного развития вузов. Вопросы функционирования «сетевого общества» 
находят свое философское осмысление в работах А. В. Назарчук [10], А. В. Меликян [9], которые предприняли попытку изучения основных характеристик международных сетей.

Международное сотрудничество в высшем образовании направлено прежде всего на интеграцию образовательных услуг высших учебных заведений в мировое, европейское и региональное пространство, на повышение конкурентоспособности не только вузов, но и в целом национальных систем высшего образования. Основой для такого сотрудничества становятся:

на национальном уровне:

- членство в специализированных глобальных и региональных международных организациях,

- заключение дву- и многосторонних международных соглашений в области высшего образования;

на уровне высших учебных заведений:

- заключение договоров о межвузовском сотрудничестве;

- вертикальная и горизонтальная академическая мобильность (как реальная, так и виртуальная);

- сетевая организация деятельности, а именно - создание университетских сетей, реализация совместных магистерских программ;

- создание совместных университетов.

Примерами международного сотрудничества в сфере высшего образования могут быть: подписание и ратификация Беларусью в 1993 г. Европейской культурной конвенции, обеспечивающей межправительственное сотрудничество в области образования на европейском уровне [3].

В мае 2015 г. Республика Беларусь присоединилась к Болонскому процессу - процессу формирования странами Европы единого образовательного пространства.

С момента вступления (1954) в ЮНЕСКО в Беларуси функционирует Национальная комиссия по делам ЮНЕСКО. В республике действуют восемь кафедр ЮНЕСКО, 11 образовательных учреждений имеют статус ассоциированных школ ЮНЕСКО.

Республикой Беларусь заключено более 30 межправительственных соглашений по сотрудничеству в сфере образования, в том числе высшего [2]. 
Международное сотрудничество в сфере высшего образования Беларуси реализуется также через членство и другие виды присутствия в глобальных организациях (ООН, ЮНЕСКО), региональных организациях (Европейский союз, Совет Европы, Центральноевропейская инициатива, Совет государств Балтийского моря, Организация черноморского экономического сотрудничества, Шанхайская организация сотрудничества) и организациях постсоветского пространства (СНГ, Союзное государство Беларуси и России) [3].

Межвузовское сотрудничество сегодня представляет один из основных видов международного сотрудничества в сфере высшего образования. Количество договоров о международном межвузовском сотрудничестве с зарубежными вузами и международными организациями растет пропорционально росту интереса к таким взаимоотношениям. Так, в Белорусском государственном университете заключено более 220 договоров о международном межвузовском сотрудничестве. Утверждение и продвижение «бренда» университетов, международное признание дипломов, повышение качества образования, обеспечение академической мобильности студентов и профессорскопреподавательского состава являются составными элементами такого сотрудничества [4].

Необходимость координации правовых основ, создание нормативной базы как национального, так и межгосударственного уровня, возникновение объединений университетов в единые сети (ассоциации), как правило, по трансграничному принципу продиктованы нарастающей постоянной потребностью в международном сотрудничестве в области высшего образования. Сегодняшние университетские сети и ассоциации созданы, как правило, руководством многих вузов. Согласование образовательных программ в рамках сети позволяет с большей эффективностью реализовывать проекты академической мобильности.

Современные тенденции международного образовательного рынка неразрывно связаны с усилением конкуренции вузов. Межвузовские связи, стратегическое партнерство позволяют вузам укреплять свои конкурентные позиции.

Сетевая организация деятельности в сфере образования - модель наиболее эффективного полноформатного взаимодействия вузовской среды. Основу сетевой формы взаимодействия составляет возможность каждого вуза - участника сети пользоваться опытом партнеров 
и делиться своим. Сетевая организация деятельности в высшем образовании включает в себя создание сетевых ассочиаций, университетских сетей и сетевых консорииумов.

В основе идеи сети заложена теория информации и коммуникации, в которой последние не просто обеспечивают связи между различными элементами общества, а представляют собой достаточно самостоятельную реальность, возникшую вследствие информационного обмена. Часто такого рода реальность именуют виртуальной, а интернет в данном контексте является не подструктурой или «копией реальности, а ее равнозначным, в онтологическом смысле, соответствием» [10].

Стремление к международному взаимопониманию и сотрудничеству предопределяет создание сетевых ассоциаций в высшем образовании. Это легло в основу Международной ассоциации по обмену студентами для получения технических навыков (IAESTE), созданной десятью европейскими странами-учредителями в январе 1948 г. в Имперском колледже в Лондоне.

Ассоциация насчитывает более 90 стран. Ежегодно она приносит пользу более чем 1,5 тыс. компаниям, университетам, а в ее обменах участвует более 350 тыс. студентов. Республика Беларусь с 2000 г. была ее ассоциированным, а с 2013 г. является полноправным членом. Национальный комитет ассоциации координирует отбор и направление студентов за рубеж, в том числе для прохождения практики. IAESTE активно сотрудничает с ЮНЕСКО, ЭКОСОС, ЮНИДО, Международной организацией труда.

Деятельность Международной ассоциации преподавателей русского языка и литературы (МАПРЯЛ), созданной в сентябре 1967 г. в Париже, заключается в распространении преподавания и изучения русского языка и литературы в мире. Она включает обмен информацией, проведение международных конференций, семинаров, симпозиумов по теоретическим и практическим вопросам преподавания русского языка, литературы и страноведения. Первым президентом ассоциации стал академик АН СССР, доктор филологических наук, лауреат Сталинской премии, почетный доктор Пражского университета В. В. Виноградов. БГУ является учредителем Белоруского общественного объединения преподавателей русского языка как иностранного (БООПРЯИ), равноправным членом Международной ассоциации преподавателей русского языка и литературы (МАПРЯЛ). 
Основанная в 1984 г. Европейская сеть информационных центров по признанию эквивалентности (ENIC - NARIC) обеспечивает путь для сравнения академической квалификации в рамках Болонского процесса. Деятельность сети направлена на улучшение мобильности студентов и работников вузов. В составе членов NARIC - организации и агентства, осуществляющие экспертизу документов об образовании и признание иностранных квалификаций. В большинстве европейских стран институты высшего образования вправе принимать собственные решения о соответствии иностранных квалификаций. В Беларуси эту работу ведет Республиканский институт высшей школы БГУ, который постоянно участвует в работе сети. Роль NARIC в основном консультативная.

В 2003 г. подписано соглашение о создании Сети международных центров релятивистской астрофизики (ICRANet). Это международная научная организация, цель которой - подготовка научных кадров. Ее деятельность связана с реализацией ряда международных исследовательских проектов в области астрофизики, космологии, теоретической и математической физики.

Сеть поддерживает программы обмена для студентов и работников известных научных центров и университетов по всему миру, проводит семинары и конференции. Координационный центр расположен в Италии, также рассматривается проект создания дополнительного центра в Ереване. Под эгидой Сети международных центров релятивистской астрофизики создана международная образовательная программа аспирантуры (IRAP PhD). БГУ участвует в сети с 2009 г. Деятельность европейской сети «Сотрудничество для высшего образования в области радиологической и ядерной инженерии» (CHERNE), созданной в 2005 г., направлена на развитие и укрепление сотрудничества университетов и научных центров Европы в области ядерных наук и технологий. CHERNE объединяет 19 университетов и научных центров, в том числе БГУ (с 2014 г.).

Идея создания университетских сетей возникла на Конгрессе университетов Империи в Лондоне (Congress of Universities of the Empire): представители британских университетов приняли решение о создании информационного бюро, которое открылось в 1913 г. и в 1948 г. получило статус Ассоциации университетов Британского содружества. Впоследствии бюро было переименовано в Ассоциацию университетов содружества. 
Выделяются следующие крупнейшие университетские сети:

- на европейском пространстве: Европейская ассоциация университетов (ЕAU/EAУ);

- на субрегиональном европейском пространстве: в Центральной Европе - Университетская сеть ЦЕИ (UniNet), в регионе Балтийского моря - Балтийская университетская программа (БУП), университетская сеть региона Балтийского моря (BSRUN), в черноморском регионе - сеть университетов Черноморского региона (BSUN);

-университетские сети пограничья: Сеть университетов пограничья (СУП);

-на постсоветском пространстве: Евразийская ассоциация университетов (ЕАУ).

В результате слияния Ассоциации европейских университетов и Конфедерации конференций ректоров Европейского союза в 2001 г. возникла Европейская ассоциация университетов (EUA/EAУ). Ее основная задача - содействие высшим учебным заведениям Европы в эффективном развитии в соответствии с современными потребностями и международными стандартами. ЕАУ насчитывает более 800 членов, среди которых индивидуальные члены - вузы, коллективные члены - конференции ректоров, а также университетские ассоциации и сети из 46 стран Европы.

Европейская ассоциация университетов является официальным представителем университетского сектора в Болонском процессе, принимает участие в работе его групп и консультационных органов, представляет мнения и взгляды членов ассоциации в Европейской комиссии, Совете Европы, ЮНЕСКО, национальных структурах по высшему образованию и науке. ЕАУ анализирует проблемы университетов, а также выявляет передовой опыт других вузов. Организация поддерживает своих членов в преодолении вызовов через реформирование структуры ученых степеней, определение стратегий развития, поддержку трансфера технологий для нужд рынка труда, повышение профессионализма руководящей деятельности.

В 2010 г. БГУ вступил в ЕАУ и в настоящее время является одним из ее организаторов.

Центральноевропейская инициатива (ЦЕИ) была создана в 1989 г. как организация, призванная содействовать развитию устойчивых связей между государствами Центральной, Западной и Вос- 
точной Европы в области политики, экономики и культуры, а также для недопущения образования новых разделительных линий в Европе. В конце 1990-х гг. основной целью ЦЕИ было провозглашено содействие европейской интеграции и сближению между ЕС и европейскими государствами, не входящими в его состав.

На саммите глав государств и правительств Центральноевропейской инициативы в 2001 г. в Триесте (Италия) была озвучена идея создания Университетской сети ЦЕИ (UniNet). Созданная в 2004 г., UniNet стала основным видом деятельности ЦЕИ в области высшего образования.

Университетская сеть ЦЕИ охватывает более 100 университетов из 18 стран. Со дня основания UniNet профинансировано 57 проектов, выделено около 700 стипендий и грантов [6].

Приоритетными направлениями UniNet являются развитие всесторонних взаимоотношений между учреждениями высшего образования стран ЦЕИ, расширение возможностей для мобильности преподавателей и студентов всех университетов в рамках ЦЕИ. Университеты как координаторы представляют свои страны. Организация межвузовских образовательных программ, конференций, семинаров, летних школ, выставок и т. д. способствует динамичному развитию академической мобильности. С 2004 г. Белорусский государственный университет стал координатором от Республики Беларусь в университетской сети ЦЕИ.

В 1991 г. в рамках Балтийской университетской программы (БУП) была создана сеть из 225 университетов и других институтов в области высшего образования, расположенных в регионе Балтийского моря. БУП создает и координирует курсы для бакалавров и магистров членов сети и спонсирует совместные проекты, ориентированные на стабильное развитие в регионе.

Работа сети координируется секретариатом БУП, работающим в Центре устойчивого развития Университета Уппсалы (Швеция). Основные направления деятельности - вопросы устойчивого развития, охраны окружающей среды и демократии в регионе Балтийского моря. Университеты-участники представляют страны, которые находятся в бассейне Балтийского моря или за его пределами, в том числе Беларусь. Белорусский государственный университет принимает активное участие в программе Балтийского университета. Около 40 студентов БГУ прошли обучение в рамках программы и участво- 
вали в международных конференциях по проблемам устойчивого развития.

В 2000 г. в г. Турку (Финляндия) была основана Университетская сеть региона Балтийского моря (BSRUN) [7]. Свыше 40 университетов стран балтийского региона объединились с целью развития международного межвузовского сотрудничества в регионе на основе интеграции образовательных процессов. С 2013 г. БГУ является ее полноправным членом. Вступлению предшествовало тесное сотрудничество БГУ с BSRUN. Представители вуза неоднократно участвовали в семинарах, конференциях и проектах сети, а в 2011 г. университет был одним из организаторов международного семинара ассоциации «Университет и бизнес: пути сотрудничества», который прошел на базе БГУ.

Сеть университетов Черноморского региона (BSUN) была основана в соответствии с рекомендациями Комитета по культуре, образованию и социальным вопросам Парламентской ассамблеи Черноморского экономического сотрудничества (ПАЧЭС) на заседании в Бухаресте в августе 1997 г. Она была учреждена в 1998 г. в Констанце в ходе Второй конференции ректоров Черноморского региона. Сегодня BSUN объединяет более 100 университетов, представляющих 12 стран - членов Организации Черноморского экономического сотрудничества (ОЧЭС).

В октябре 2013 г. создан международный консорциум учебных заведений из Польши, Литвы, Беларуси, Украины и России - Сеть университетов пограничья (СУП). Организатором и координатором сотрудничества выступает университет Белостока, а его партнерами вузы Барановичей, Бреста, Воронежа, Гродно, Калининграда, Каунаса, Львова, Тернополя. 10 вузов подписали договор о создании сети.

В основе идеи - формирование добрососедских отношений, при которых административное деление не должно влиять на свободный обмен мыслями и возможность сотрудничества, которое будет касаться совместного привлечения международных грантов и реализации научных проектов, обмена услугами по исследованиям и внедрению их результатов.

В планах - подготовка совместных конференций и публикаций, другие мероприятия, направленные на расширение приграничного сотрудничества, поддержку общественного и экономического развития, защиту окружающей среды на приграничной территории. Со- 
глашение предусматривает организацию совместных культурных и спортивных мероприятий.

В 1989 г. по инициативе Московского государственного университета имени М. В. Ломоносова, поддержанной двадцатью крупнейшими университетами СССР, была создана Ассоциация университетов СССР, преобразованная в 1992 г. в Евразийскую ассоциацию университетов (ЕАУ). В настоящее время она объединяет 128 университетов Азербайджана, Армении, Беларуси, Грузии, Казахстана, Кыргызстана, Латвии, Молдовы, России, Таджикистана, Туркменистана, Узбекистана и Украины [5].

Белорусский государственный университет является одним из организаторов ЕАУ, участвует в деятельности Белорусской ассоциации содействия ООН.

Важное направление деятельности ассоциации - работа с молодежью и трудовыми коллективами университетов. ЕАУ учреждены Студенческая ассоциация университетов стран СНГ и Евразийская ассоциация профсоюзных организаций университетов, которые регулярно проводят съезды и мероприятия, направленные на укрепление сотрудничества.

При ассоциации действуют центры по отдельным направлениям сотрудничества университетов стран СНГ. Евразийская ассоциация университетов аккредитована при Межпарламентской ассамблее стран СНГ и Совете по сотрудничеству в области образования государств - участников СНГ. Она взаимодействует с другими международными организациями университетов. Ассоциация действует через многочисленные конференции, форумы, межвузовские связи и контакты.

Богатый опыт сетевого взаимодействия университетов в единой образовательной среде накоплен в Российской Федерации. Широкое распространение получили региональные ассоциации образовательных и научных учреждений. Структура сетевых консорциумов представляет собой научно-образовательные центры на базе ведущих университетов в федеральных округах. В их составе есть вузы, академические институты и организации бизнес-сообщества. Пример такого взаимодействия - Национальный исследовательский Томский государственный университет (ТГУ) в статусе соучредителя Ассоциации образовательных и научных учреждений «Сибирский открытый университет» и Суперкомпьютерного консорциума университе- 
тов России при участии МГУ им. М. В. Ломоносова и других университетов.

Высшие учебные заведения Беларуси активно сотрудничают с рядом других международных университетских сетей и ассоциаций. Среди них: Межуниверситетский центр исследований и сотрудничества в Восточной и Юго-Восточной Европе (CIRCEOS), Ассоциация школ Центральной и Восточной Европы по исследованиям в области международных отношений, Международный союз таможенных университетов (International Network of Customs Universities, $I N C U)$, Сеть международных центров релятивистской астрофизики (ICRANet) и др.

Во многих кластерных образованиях вузы республики являются не только участниками, но и координаторами и организаторами. Это позволяет совершенствовать систему подготовки специалистов с учетом требований мирового рынка труда, повышать качество обучения и управления вузом.

Сотрудничество партнеров в области обучения и развития академических контактов между студентами, преподавателями и научными работниками, научных исследований, организация и проведение совместных конференций, подготовка и издание совместных публикаций в рамках университетских сетей способствуют развитию многостороннего международного сотрудничества. Вузы-партнеры, заинтересованные в наиболее эффективном взаимодействии, в том числе с новыми вузами, стремятся к расширению своих границ.

Беларусь вошла в список стран, присоединившихся к Болонскому процессу. Границы европейского пространства высшего образования расширились. Зона европейского образовательного пространства включает 48 стран-участниц из 49 стран, которые ратифицировали Европейскую культурную конвенцию Совета Европы (1954).

Сетевая модель выступает эффективным видом международного сотрудничества. Она обеспечивает расширение академической мобильности, способствует интернационализации и ускорению инновационного развития вузов, освоению новых методов организации совместной работы, применяемой в сети, при непрерывном обмене информацией - приобретению новых ресурсов и знаний, формированию межвузовских команд, обладающих высокими компетенциями, повышению известности ученых вуза, занятию вузом высокого места в рейтинге. 
Совместная деятельность национальных систем образования в международных университетских сетях функционирует на основе объективной потребности в коммуникации с готовностью предоставления ресурсной базы для общего пользования и открытого доступа к ней всех участников сети.

К новой форме в рамках двустороннего взаимодействия можно отнести создание совместных университетов. Сегодня эта форма широко распространена в Китае. Здесь создаются вузы с участием Австралии, Великобритании, Германии, Гонконга, Дании, США.

В сентябре 2015 г. при поддержке правительств России и Китая было подписано соглашение между Московским государственным университетом им. М. В. Ломоносова и Пекинским политехническим институтом о создании Университета МГУ - ППИ в Шэньчжэне. Параллельно начат процесс гармонизации российского и китайского законодательства в сфере образования. В России, в частности, принят соответствующий федеральный закон.

Международное сотрудничество в сфере образования способствует развитию взаимовыгодных отношений высших учебных заведений с организациями-партнерами. Реализация проектов с зарубежными партнерами путем участия в программах международных организаций и фондов расширяет возможности сотрудничества, способствует росту международной конкурентоспособности. В то же время сетевая модель может служить ее участникам защитой в постоянно меняющихся условиях.

\section{Библиографические ссылки}

1. Об утверждении Основных направлений внутренней и внешней политики Республики : Закон Респ. Беларусь от 14 нояб. 2005 г. № 60-3 // Новости Беларуси [Электронный ресурс]. URL : http://laws.newsby.org/documents/laws/law0361.htm (дата обращения : 28.02 2015).

2. Международные соглашения // М-во образования Респ. Беларусь [Электронный ресурс]. URL: http://www.edu.gov.by/ru/main.aspx?guid=22261 (дата обращения: 15.09 2015).

3. Беларусь и международные организации // М-во иностр. дел Респ. Беларусь [Электронный pecypc]. - URL: http://mfa.gov.by/mulateral/organization/ (дата обращения : 01.09 2015).

4. Международное межвузовское сотрудничество // БГУ [Электронный ресурс]. - URL: http://www.bsu.by/main.aspx?guid=11681 (дата обращения : 04.09 2015).

5. Об ассоциации // Евразийс. ассоц. ун-тов [Электронный ресурс]. - URL : http://www.eau. msu.ru (дата обращения : 01.09 2015).

6. Research and Innovation // CEI [Электронный pecypc]. - URL : http://www.cei.int/content/ research-and-innovation (дата обращения : 01.09 2015). 
7. Общая информация // Университетская сеть региона Балтийского моря [Электронный реcypc]. - URL : http://www.bsrun.org/ru/obshchaya-informaciya (дата обращения : 05.09.2015).

8. Абдраимов Б. Ж. Межвузовское сотрудничество как ключевой фактор развития общего образовательного пространства : евразийское измерение // IA-CENTR [Электронный реcypc]. - URL : www.ia-centr.ru /expert/4223 (дата обращения : 05.09 2015).

9. Меликян A. B. Основные характеристики международных сетей университетов // Вопр. образования [Электронный ресурс] - URL : http://vo.hse.ru (дата обращения : 15.09 2015).

10. Назарчук A. B. Сетевое общество и его философское осмысление // Вопр. философии. 2008. - № 7. - С. 61-75.

11. Неретина $E$. A. Сетевое взаимодействие - основа динамичного развития вузов // Киберленинка [Электронный ресурc]. - URL : http://www.cyberleninka.ru (дата обращения : 05.09.2015).

Международное сотрудничество в сфере высшего образования (сетевая организация деятельности) (Вероника Добровольская)

Рассматривается сетевая организация деятельности в сфере образования как один из важнейших видов международного сотрудничества. Автором выделяются крупнейшие сетевые ассоциации и сетевые университетские объединения. Анализируется участие Республики Беларусь в европейском и евразийском образовательном пространстве через сетевое взаимодействие. Подчеркивается значение реализации приоритетных направлений деятельности университетских сетей, направленных на углубление взаимопонимания между народами Европы.

\section{Ключевые слова}

Республика Беларусь; международное сотрудничество; высшее образование; межвузовское сотрудничество; сетевая организация деятельности; университетские сети, сети ассоциаций.

International cooperation in the field of higher education (network organization of activities) (Veranika Dabravolskaya)

The article deals with the organization of the network activities in the field of education as one of the most important forms of international cooperation. The author describes the largest networks of associations and universities. The direct participation of Belarus in the European educational space is analyzed by examples of networking. The importance of im- 
plementing of the university networks priorities aimed at deepening of mutual understanding between the Europeans is stressed.

\section{Key words}

Republic of Belarus; international cooperation; higher education; university cooperation; network organization of activities; university networks; networks of associations.

Статья поступила в сентябре 2015 г.

Рецензенты:

Шарапо А. В. - доктор исторических наук, профессор кафедры международных отношений факультета международных отношений Белорусского государственного университета;

Есин Р. О. - доктор политических наук, профессор кафедры международных отношений Академии управления при Президенте Республики Беларусь. 


\section{ТРЕУГОЛЬНИК ОТНОШЕНИЙ}

\section{«США - ЯПОНИЯ - РЕСПУБЛИКА КОРЕЯ»: \\ ОФОРМЛЕНИЕ НОВОГО ГЕОПОЛИТИЧЕСКОГО ЦЕНТРА \\ В АЗИАТСКО-ТИХООКЕАНСКОМ РЕГИОНЕ}

\section{М. В. Зантович}

магистрант факультета международных отночений

Белорусского государственного университета

УДК 327(73:520:519)

К началу XXI в. отношения Республики Корея (РК), США и Японии прошли трансформацию от двусторонних оборонных союзов США с союзниками в субрегионе Северо-Восточной Азии (СВА) до развивающейся системы трехсторонних отношений партнеров, претендующих на геополитическое лидерство в Азиатско-Тихоокеанском регионе (АТР).

В силу ряда факторов треугольник отношений «США - Япония - РК» привлекает внимание исследователей и политиков. Во-первых, АТР, по определению А. Л. Лукина, превращается в «глобальный регион» наравне с Евроатлантикой и Ближним Востоком: на его долю приходится $40 \%$ от объема мировой торговли и внешнеэкономических операций [1].

Во-вторых, динамика безопасности в АТР, включая территориальные претензии, ядерную программу Северной Кореи, нерешенность корейского вопроса, создают риск эскалации конфликта. В ситуации отсутствия в АТР единой системы региональной безопасности [2] встает вопрос о необходимости институализации существующих форм сотрудничества.

B-третьих, как отмечается в Стратегии национальной безопасности США (2015 г.), Соединенные Штаты будут осуществлять «перебалансировку» своих сил в сторону Азиатско-Тихоокеанского региона [3]. Наконец, происходит модернизация и рост мощи Китая, который начинает конкурировать с Японией за место регионального гегемона. В таких условиях Южная Корея все чаще получает название «swing country» - государства, балансирующего между крупными игроками: США, Китаем и Японией. Присоединение РК к тому или иному фор- 
мату сотрудничества рассматривается исследователями как ключевой параметр архитектуры безопасности в СВА [4].

Перечисленные выше обстоятельства превратили АТР в «поле Большой игры» за лидерство и новые сферы влияния.

С позиций геополитики именно это определяет необходимость изучения треугольника отношений трех ключевых стран региона.

Целью данной статьи является изучение динамики отношений США - Япония - РК в начале XXI в. Субъекты международных отношений, в том числе Республика Беларусь, вынуждены учитывать тенденции развития АТР для успешного сотрудничества в сфере торговли, безопасности, прав человека и т. п. Кроме того, с учетом необходимости выработки стратегии участия Республики Беларусь в интеграционных форматах сотрудничества на постсоветском пространстве особый интерес представляют отношения США, РК и Японии как модель многосторонних отношений.

Тема трехсторонних отношений Республики Корея, США и Японии начала получать свое освещение в литературе сравнительно недавно - с начала 2000-х гг, после обострения глобальных вызовов по всему миру в целом и в Азиатско-Тихоокеанском регионе - в частности. В историографии вопроса можно отметить различный уровень разработанности темы при разнице подходов исследователей.

Наибольший объем и разнообразие исследований представлены в работах зарубежных ученых. Научно-исследовательская служба конгресса США и Центр стратегических и международных исследований в Вашингтоне делают упор на практическую ориентированность выводов и принятие политического решения. Охват более чем широк: перспективы и альтернативы отношений США и Японии [5], оценка текущего уровня отношений США и Южной Кореи [6], переговоры о Транстихоокеанском партнерстве США в АТР [7]. В рамках разработки тематики трехсторонних отношений выделяется работа Д. Кунико, Б. Глоссермана, Д. Вардена «Трехстороннее сотрудничество в Северо-Восточной Азии: ожидания и ограничения» [8], а также выступление от 14 апреля 2015 г. М. Грина перед конгрессом «Вопросы политики безопасности, присущие Азиатско-Тихоокеанскому региону» [9].

На постсоветском пространстве данная тематика исследуется в Институте Дальнего Востока РАН и Институте США и Канады. С. Г. Лузянин в работах «Две Кореи: сравнительный анализ моделей 
развития» и «Северо-Восточная Азия: внутренние и внешние измерения развития и безопасности» обозначает основное проблемное поле субрегиона СВА, динамику развития основных геостратегических игроков $[10 ; 2]$. А. В. Семин в статье «США - Япония - Южная Корея: трехсторонний альянс может стать реальностью?» [12] уделяет внимание как основополагающему военному союзу в СВА - США и Японии [11], так и возможности формирования трехстороннего формата отношений США - РК - Японии.

В работах белорусских ученых освещение темы трехсторонних отношений носит фрагментарный характер. Основной объем литературы концентрируется на вопросах безопасности и двусторонних отношений.

Следует отметить исследование аналитика Центра стратегических и внешнеполитических исследований (Минск) Г. Шутова, в рамках которого проект Транстихоокеанского партнерства (ТТП) рассматривается как фактор, определяющий глобальную повестку дня в ближайшее десятилетие [13]. Дается оценка геостратегической роли АТР и влиянию региональных процессов на белорусские интересы.

Развитие трехсторонних отношений в значительной степени определилось историческим контекстом, в частности событиями XX в. Установление биполярной системы международных отношений после Второй мировой войны привело к глобальному противостоянию двух сверхдержав - СССР и США. Именно созданный в период холодной войны военно-политический блок во главе с США стал основой для развития трехсторонних отношений после распада СССР.

Так, в ходе поствоенного урегулирования в конституции Японии закрепился статус США как гаранта безопасности. Вашингтон получал право размещать на японской территории свои вооруженные силы и военные объекты. США также находились у истоков создания РК, впитавшей во многом опыт американской политической культуры при разработке структуры государственного устройства. Военно-политический договор «О совместной обороне» определил блоковый характер взаимоотношений между двумя странами.

Завершение холодной войны ознаменовало складывание новых условий международных отношений. В АТР начался интенсивный поиск новых форматов экономического и военно-политического сотрудничества. Данные процессы стали тем полем, в котором развивались трехсторонние отношения РК - США - Японии. 
Соединенные Штаты выступают в качестве лидера в треугольнике отношений трех стран. Стратегия национальной безопасности США 2015 г. предполагает масштабную «перебалансировку» в сторону АТР [3]. По оценкам авторов Стратегии, предстоящие пять лет почти половину экономического роста за пределами США будет обеспечивать Азия. При этом динамика безопасности в регионе, включая спорные территориальные претензии на море и провокационные действия Северной Кореи, создает риск эскалации напряженности и конфликта. Чтобы реализовать эту концепцию, США предполагают разнообразить отношения в сфере безопасности в Азии. Это включает совершенствование американских альянсов с Японией, Южной Кореей, Австралией и Филиппинами, а также укрепление взаимодействия между ними [3].

С целью упрочения общих правил и норм среди региональных институтов Вашингтон ориентируется на развитие взаимодействия с Ассоциацией государств Юго-Восточной Азии (АСЕАН), Восточноазиатским саммитом, Азиатско-Тихоокеанским экономическим сотрудничеством (АТЭС). В деле развития открытости и прозрачности азиатских экономик центральную роль играет Транстихоокеанское партнерство [3].

Опросы общественного мнения США свидетельствуют о том, что большинство американцев рассматривают АТР в качестве наиболее важного региона для национальных интересов США, и это не случайно: пять из семи ядерных держав (не включая КНДР) находятся в регионе; 58 \% торгового оборота США приходится на страны АТЭС; Азиатский банк развития прогнозирует рост доли АТР до $51 \%$ мирового ВВП к 2050 г. [9].

Ключевыми партнерами США в СВА традиционно являются Южная Корея и Япония, а с 2010 г. Вашингтон начал уделять внимание усилению трехстороннего сотрудничества в сфере безопасности [14]. Развитию сотрудничества способствует схожесть позиций трех стран по ряду глобальных вопросов, от Арабской весны до борьбы с пиратством, от Афганистана до безопасности в АТР [14]. Однако основными причинами, обусловившими необходимость углубления отношений США, РК и Японии, стали угрожающая политика КНДР и наращивание экономической и военной мощи Китая.

Несмотря на ряд тактических разногласий, периодически возникающих у союзников, США, РК и Япония разделяют общий взгляд по 
широкому кругу вопросов и угроз, связанных с Северной Кореей. Все они обеспокоены провокациями со стороны КНДР, которые ставят под угрозу безопасность в СВА. Они также вынуждены предпринимать меры для противодействия развитию северокорейской ядерной программе и наращиванию обычных вооружений. Так, все три государства осудили запуск северокорейского спутника 13 апреля 2012 г., который в нарушение резолюций ООН был осуществлен на базе технологий запуска баллистических ракет [14]. США, РК и Япония заинтересованы в безъядерной КНДР, которая могла бы мирно сосуществовать со своими соседями и стать полноправным членом международного сообщества [14].

Китай представляет собой еще один вызов для интересов трех стран. Множество опасений вызывают вектор развития КНР на фоне политических скандалов (например, о Бо Силае), противоречивые действия китайского руководства в вопросах, связанных с КНДР, а также ограниченность информации о военной модернизации страны и ее демократизации [14].

Трехстороннее сотрудничество осложняется различным восприятием Китая каждой из стран. США рассматривают КНР в качестве ключевого партнера в решении глобальных проблем, но также и как конкурента в сфере экономики и распространения своей системы ценностей [3]. Япония в отношении Китая сосредоточена на вопросах территориальных споров, китайской модернизации вооруженных сил и потенциала КНР стать региональным гегемоном [4]. Южная Корея имеет тесные экономические связи с китайской стороной, однако трения возникают в связи с территориальными претензиями на затопляемый скалистый остров Иодо, установлением КНР опознавательной зоны ПВО, которая пересекается с аналогичной зоной РК, а также патронажем Китая над северокорейской стороной [4].

Отношения РК и Японии с Китаем имеют двойственный характер, сочетая в себе взаимозависимость и соперничество. До 2013 г. сотрудничество РК, Японии и КНР развивалось по нарастающей, особенно после глобального финансового кризиса 2008 г. В 2009-2012 гг. лидеры трех стран ежегодно проводили саммиты, учредили трехсторонний секретариат в Сеуле, подписали соглашение об инвестициях и заложили основы для начала переговоров о трехстороннем соглашении о свободной торговле (ССТ) [15]. В 2013 г., однако, усилились трения между РК и Японией, а также между Китаем и Японией, что в 
значительной мере заморозило сотрудничество трех стран. Для выхода из ситуации стагнации президент Южной Кореи Пак Кын Хе выступила с инициативой по сотрудничеству и миру в Северо-Восточной Азии. В рамках инициативы предполагается согласие Японии с «верным пониманием истории», а также установление между США и Китаем «прогрессивных отношений» [16].

Основная трудность для развития и углубления отношений РК, США и Японии заключена в слабости звена «РК - Япония». Как отмечает исследователь К. Кан, за последние 50 лет изменился «вертикальный» характер отношений между Японией и РК [17]. Одна из причин изменений - сокращение разницы в экономическом уровне развития: к 2000 г. Южная Корея представляла собой пример «новой индустриальной экономики», которая стремительно вошла в двадцатку ведущих экономик мира. Аналогичным образом ситуация выравнивается в военной сфере - разрыв в военном потенциале двух стран постепенно сокращается [17].

С одной стороны, две страны являются важнейшими друг для друга соседями, а их отношения рассматриваются как необходимые для обеспечения мира и процветания в СВА. С другой стороны, болезненное историческое прошлое, его интерпретации, а также территориальные споры находятся в конфликтной фазе и не способствуют развитию сотрудничества двух стран.

В целом о высоком уровне сотрудничества РК и Японии говорить не приходится. В сфере обороны оба государства развивают свои системы ПРО - в той или иной степени под патронажем США. Совместные проекты развиваются также по инициативе Соединенных Штатов: достигнуто соглашение о проведении трехсторонних учений ВMC ежегодно, начиная с 2012 г. В 2013 г. РК и Япония приняли участие в «беспрецедентных для союзников США» многонациональных учениях ВВС [18]. Последними попытками институализации сотрудничества в сфере безопасности стали две идеи: Соглашение о всеобщей безопасности военной информации и Соглашение о военных поставках и взаимном обслуживании [18]. Над данными соглашениями работа идет с 2012 г., но их заключение затягивается.

Текущий уровень отношений между Южной Кореей и Японией во многом связан с развитием политического диалога, в том числе между лидерами двух государств. Отношения заметно ухудшились после избрания Пак Кын Хе на пост президента Южной Кореи и 
Синдзо Абэ - премьер-министра Японии. Как отмечает исследователь Терри, личностный фактор оказывает серьезное влияние на уровень отношений [4, с. 13]. Пак Кын Хе вынуждена активно доказывать, что не допускает преференций Японии в свете того, что южнокорейская оппозиция клеймит ее отца, бывшего президента Пак Чон Хи, прояпонским политиком. Более того, президент Пак широко известна своим отстаиванием прав «женщин для утешения» получать моральную и материальную компенсацию, поэтому она лично крайне негативно воспринимает позицию японской стороны по этому вопросу. Синдзо Абэ в свою очередь известен своими националистическими взглядами, а также приверженностью идеям ревизионизма истории: в частности, отрицания виктимизации и притеснения соседей во времена колониальной Японии. В 2013 г. Абэ сделал заявление, что его правительство не будет вновь приносить извинений за действия Японии в период войны после аналогичных извинений премьер-министра М. Томиити в 1995 г. [4, с. 13].

Оба лидера не склонны к компромиссу в целом и по вопросам истории - в частности. Ситуацию можно охарактеризовать как порочный круг. Пак ожидает официального признания и извинений японского кабинета за действия Японии в первой половине XX в., связывая остальные аспекты двусторонних отношений с историческим вопросом. Премьер-министр Абэ стремится восстановить национальную гордость, что приводит к неоднозначным попыткам «переписать историю» в учебниках и получить право на коллективную самооборону. В таких условиях не ясно, будут ли две стороны иметь возможность или желание предпринять попытки сделать нечто большее для улучшения отношений, нежели поддерживать ad hoc сотрудничество.

В марте 2014 г. по инициативе Б. Обамы прошла трехсторонняя встреча глав государств в Гааге в рамках саммита по ядерным вопросам. Хотя цель встречи была связана с необходимостью выработки совместных подходов к северокорейской ядерной программе, ключевой задачей было налаживание более тесного контакта между Сеулом и Токио [15]. Во многом данная встреча способствовала организации более частых визитов на уровне министерств в период с марта 2014 г. по апрель 2015 г.

Отношения Японии и РК имеют непростой характер не только на уровне официальных контактов, но и в восприятии населения двух стран. По данным BBC World Service Poll (2014 г.), только 19 \% япон- 
цев позитивно воспринимают влияние Южной Кореи, в то время как $28 \%$ имеют негативный взгляд на ее роль в мире. В РК показатели имеют более полярный характер: $21 \%$ опрошенных воспринимают Японию позитивно, а $67 \%$ - негативно [19]. РК оказывается второй страной после Китая с крайне низкой оценкой роли Японии в современном мире.

Однако, как отмечает Сью Ми Терри в совместной американоюжнокорейской работе [4], текущий низкий уровень сотрудничества Республики Корея и Японии может смениться периодом углубления взаимодействия в ответ на угрозы безопасности и в связи с экономическими выгодами.

Так, провокации Пхеньяна в 2010-2013 гг. - потопление южнокорейского корвета «Чхонан», очередные ядерные испытания, запуск ракет малого радиуса действия, признание северокорейской стороны в похищении японских граждан - затрагивают как Сеул, так и Токио и становятся предпосылками для координации усилий в сфере безопасности. Остается открытым вопрос о способности лидеров двух стран преодолеть взаимное недоверие и противоречия по ряду вопросов.

Несмотря на неустойчивость взаимоотношений по оси Токио Сеул, в треугольнике отношений начинают устанавливаться все более сложные связи в различных сферах. Трехстороннее развитие отношений между РК, США и Японией проходит в двух основных взаимодополняющих направлениях: военно-оборонном и экономическом.

С точки зрения обеспечения безопасности, в условиях неспособности РК и Японии самостоятельно противодействовать всему спектру угроз со стороны КНДР и Китая [4], вице-адмирал ВМС Южной Кореи Хо Саб Чжун указывает на необходимость развития трехстороннего военно-морского сотрудничества по ряду направлений: ПРО морского базирования и нераспространение ОМУ; противоподлодочная оборона и минная оборона; подготовка к провокациям со стороны КНДР [20]. Также особое внимание должно быть уделено усилиям по борьбе с пиратством и сотрудничеству по ликвидации последствий аварий и катастроф.

Большинство исследователей сходятся во мнении о том, что основой для углубления взаимодействия являются трехсторонние совещания по вопросам обороны, проводимые каждый год с 2008 г. [4]. Многосторонние учения с большим количеством участников, такие как RIMPAC (учения стран ATP), также могут использоваться в каче- 
стве контекста для создания доверительной атмосферы и партнерских отношений между Кореей и Японией [21]. Кроме того, свобода мореплавания и противостояние произвольным и внезапным объявлениям новых опознавательных зон ПВО являются вопросами, по которым у трех стран существуют общая озабоченность и меры воздействия [21].

При этом безопасность в регионе напрямую будет зависеть от того, удастся ли включить в эту систему взаимоотношений Китай [20].

Важным форматом сотрудничества как трех стран, так и всех основных участников региональных международных отношений СВА являются шестисторонние переговоры по северокорейской ядерной программе. В январе 2015 г. Япония, США и РК провели в Токио консультации трех стран по проблеме возобновления переговорного процесса. Состоялся обмен мнениями о ядерных разработках КНДР. По данным агентства Киодо, «высока возможность, что они также обсудили дальнейший ответ на требования КНДР ввести мораторий на ее ядерные испытания в обмен на прекращение военных учений США и Южной Кореи» [22].

Экономическим измерением «поворота» США в АТР является Транстихоокеанское партнерство (ТТП). ТТП представляет собой проект регионального соглашения о свободной торговле, переговоры о вступлении в которое ведут с 2011 г. США, Австралия, Бруней, Канада, Чили, Япония, Малайзия, Мексика, Новая Зеландия, Перу, Сингапур и Вьетнам [7]. Многие из стран - участниц переговоров о соглашении о свободной торговле уже имеют ССТ с Соединенными Штатами.

Южная Корея не присоединилась к переговорам о создании ТТП. В начале 2014 г. РК начала консультации со странами - участницами переговорного процесса с целью возможного присоединения, но к началу 2015 г. окончательное решение принято не было. Все участники являются членами АТЭС, и у РК как члена этой организации есть шанс успешно принять участие в ТТП.

В условиях функционирования ССТ между РК и США с 2012 г. присоединение РК к ТТП представляется естественным развитием процесса либерализации торговли в регионе. Более того, в случае присоединения РК к ТТП будет создан важный прецедент экономической интеграции в АТР: будучи участником как ТТП, так и ряда дру- 
гих ССТ (РК - Китай, РК - Китай - Япония, РК - США, Всеобъемлющее региональное экономическое партнерство АСЕАН+6), Южная Корея сможет играть роль связующего звена между данными соглашениями [23].

В конгрессе США серьезное внимание уделяется увязыванию проблематики прав человека с участием в ТТП. Как отмечает С. Г. Лузянин, «проект ТТП направлен на ущемление региональных, экономических интересов Китая» [13]. Но Г. Шутов не согласен с таким взглядом. По его мнению, цель США - это «скорее заставить Китай играть по американским правилам, чем маргинализировать ядерную державу с более чем миллиардным населением» [13]. Так, вероятно, Китай будет участвовать в ТТП опосредованно - через китайские компании, владеющие активами вьетнамских, американских и других предприятий. Исследователь не исключает, что впоследствии будет разработан механизм ТТП+1, позволяющий Китаю взаимодействовать с ТТП, пусть и ограниченно [13].

В целом, как отмечает Д. Най, в сегодняшней информационной эре успех государства обеспечен не только и не столько тем, чья армия сильнее, а тем, чья история звучит убедительнее. США используют «умную силу» (smart power), вкладываясь в глобальные общественные интересы - экономический рост, развитие здравоохранения, преодоление негативных экологических изменений.

Именно таким образом создается мировая система, в которой ведущая держава может сохранять свои позиции и противостоять вызовам современности [24]. Развитие трехсторонних отношений между США, Японией и РК во многом определяется ролью США и американскими инициативами.

Подводя итог, необходимо отметить, что интересы Японии, Южной Кореи и Соединенных Штатов объединены вопросами безопасности, которые становятся более острыми с ростом мощи Китая и продолжающейся нестабильностью в Северной Корее. В условиях функционирования двусторонних альянсов США с РК и Японией для Вашингтона закономерным представляется объединение системы союзов в единую структуру безопасности. Трем странам необходимо приложить усилия для налаживания отношений между Японией и Южной Кореей - слабым звеном трехсторонних отношений. В сфере экономики наиболее перспективен проект Транстихоокеанского партнерства: в случае успешной реализации и присоединения к нему РК 
ТТП станет крупнейшим соглашением о свободной торговле в АТР. Таким образом, США осуществляют стратегический поворот в АТР, заявленный в Стратегии национальной безопасности США 2015 г., а ключевые партнеры - РК и Япония - получают возможность реализовывать свои национальные интересы. Так оформляется треугольник отношений, который обладает военно-стратегическим и экономическим потенциалом стать ведущим геополитическим центром в Азиатско-Тихоокеанском регионе.

\section{Библиографические ссылки}

1. Лукин А. Л. Перспективы сотрудничества в Северо-Восточной Азии // Журнал теории международных отношений и мировой политики «Международные процессы» [Электронный pecypc]. - URL : http://www.intertrends.ru/twenty-second/008.htm (дата обращения : 29.04.2015).

2. Лузянин С. Г. Северо-Восточная Азия: внутренние и внешние измерения развития и безопасности // Институт Дальнего Востока PAН [Электронный ресурс]. - URL : http://www.ifesras.ru/massmedia/21/469-severo-vostochnaya-aziya-vnutrennie-i-vneshnie-izmereniya-razvitiya-ibezopasnosti (дата обращения : 29.04.2015).

3. Стратегия национальной безопасности США. Февраль 2015 // ИноСМИ [Электронный реcypc]. - URL : http://inosmi.ru/op_ed/20150213/226255885.html (дата обращения : 19.05.2015).

4. Asia's Slippery Slope: Triangular Tensions, Identity Gaps, Conflicting Regionalism, and Diplomatic Impasse Toward North Korea. Joint U.S.-Korea Academic Studies / Editor-in-Chief Gilbert Rozman. - Princeton University, Korea Economic Institute of America. - Vol. 25. - 2014.

5. Cooper W. H. U.S. - Japan Economic Relations: Significance, Prospects, and Policy Options. Congressional Research Service. - February 18, 2014.

6. U.S.-South Korea Relations / Mark E. Manyin, Mary Beth D. Nikitin, Emma Chanlett-Avery, William H. Cooper, Ian E. Rinehart. - Congressional Research Service. - June 24, 2014.

7. The Trans-Pacific Partnership (TPP) Negotiations and Issues for Congress / Ian F. Fergusson, Mark A. McMinimy, Brock R. Williams. - Congressional Research Service. - March 20, 2015.

8. Trilateral Cooperation in Northeast Asia: Expectations and Limitations. A conference report of the ROK-Japan-US Trilateral Young Leaders Dialogue / Julia Cunico, Brad Glosserman, John K. Warden. - Pacific Forum CSIS. Young Leaders. - Issues \& Insights, Vol. 15, № 1. - Seoul, Republic of Korea. - November 2014.

9. Green M. J. U.S. Defense Policy Issues Pertaining to the Asia-Pasific Theatre. - Statement before the Senate Armed Services Committee. - Center for Strategic and International Studies (CSIS). - April 14, 2015.

10. Лузянин С. Г. Две Кореи: сравнительный анализ моделей развития // Фонд исторической перспективы [Электронный ресурс]. - URL : http://www.perspektivy.org/print.php?ID=114823 (дата обращения : 29.04.2015).

11. Семин А. В. США - Япония: полвека альянса // США - Канада. Экономика, политика, культура. - № 8, Август 2010. - С. 34-46.

12. Семин А. В. США - Япония - Южная Корея: трехсторонний альянс может стать реальностью? // Сайт Института Дальнего Востока Российской академии наук (ИДВ РАН) [Элек- 
тронный ресурс]. - 18.02.2011. - URL : http://www.ifes-ras.ru/massmedia/21/265-ssha-yaponiyayuzhnaya-koreyatrexstoronnij-alyans-mozhet-stat-realnostyu. (дата обращения : 05.04.2015).

13. Шутов $Г$. Транс-Тихоокеанское партнерство будет определять глобальную повестку дня в ближайшее десятилетие // Центр стратегических и внешнеполитических исследований [Электронный ресурс]. - URL : http://csfps.by/new-research/trans-tihookeanskoe-partnerstvobudet-opredelyat-globalnuyu-povestku-dnya-v-blizhayshee. (дата обращения : 20.05.2015).

14. Zagoria D. S. U.S.-Japan-ROK Trilateral Dialogue. - The National Committee on American Foreign Policy (NCAFP). - May 21-22, 2012.

15. Japan - U.S. Relations: Issues for Congress / Emma Chanlett-Avery, Mark E. Manyin, Ian E. Rinehart, Rebecca M. Nelson, Brock R. Williams. - Congressional Research Service. - April 23, 2015.

16. Park's speech at U.S. Congress // Yonhap News Agency [Electronic resource]. - URL : http://english.yonhapnews.co.kr/national/2013/05/08/4/0301000000AEN20130508010800315F.HT ML (date of access : 16.05.2015).

17. Кимура Кан. Япония и Корея : путь к новым отношениям // Nippon Communications Foundation [Электронный ресурс]. - 15.04.2015. - URL : http://www.nippon.com/ru/indepth/a04001/?pnum=1 (дата обращения : 30.04.2015).

18. Hess A.A.C. Japan and Korea: Opportunities for Cooperation / Ashley A.C. Hess, John K. Warden // The National Interest [Electronic resource]. - URL : http://nationalinterest.org/ commentary/japan-korea-opportunities-cooperation-10076 (date of access : 12.05.2015).

19. BBC World Service Poll // EMBARGO 23:01 GMT [Electronic resource]. - 22 May 2013. URL : http://www.globescan.com/images/images/pressreleases/bbc2013_country_ratings/2013_ countr_rating_poll_bbc_globescan.pdf (date of access : 10.05.2015).

20. Ho-Sub Jung. ROK - US - Japan Naval Cooperation in the Korean Peninsula Area: Prospects for Multilateral Security Cooperation. - International Journal of Korean Studies. - Spring 2012.

21. Колдер К. Стратегический треугольник США - Япония - Южная Корея : возникающие угрозы и перспективы сотрудничества // Nippon Communications Foundation [Электронный pecypc]. - 24.03.2014. - URL : http://www.nippon.com/ru/in-depth/a02702/ (дата обращения : 30.04.2015).

22. Япония, США и Южная Корея сверили позиции по ядерной проблеме КНДР // РИА Новости [Электронный ресурс]. - 28.01.2015. - URL : http://ria.ru/world/20150128/1044637 616.html (дата обращения): 05.04.2015.

23. Schott J. J., Cimino C. Should Korea Join the Trans-Pacific Partnership? - Peterson Institute for International Economics. - September, 2014.

24. Nye J.S. Get Smart. Combining Hard and Soft Power // Foreign Affairs [Electronic resource]. URL : https://www.foreignaffairs.com/articles/2009-07-01/get-smart (date of access : 30.04.2015).

Треугольник отношений "США - Япония - Республика Корея»: оформление нового геополитического центра в Азиатско-Тихоокеанском регионе (Мария Зантович)

Рассмотрены трехсторонние отношения между Республикой Корея, США и Японией в начале XXI в. Отмечается, что интересы трех стран объединены вопросами безопасности, которые становятся все острее с ростом мощи Китая и продолжающейся нестабильностью в Северной Корее. В условиях функционирования двусторонних альян- 
сов США с Республикой Корея и Японией для Вашингтона закономерным представляется объединение системы союзов в единую структуру безопасности. Трем участникам необходимо приложить усилия для налаживания двусторонних отношений между Японией и Южной Кореей - «слабым звеном» треугольника отношений.

Проект Транстихоокеанского партнерства выступает в качестве экономического измерения трехстороннего формата сотрудничества. В случае успешной реализации и присоединения к нему Южной Кореи Транстихоокеанское партнерство станет крупнейшим соглашением о свободной торговле в АТР, где роль лидера очевидно будет принадлежать США. Оформляется «треугольник» отношений, который обладает потенциалом стать ведущим геополитическим центром в ATP.

\section{Ключевые слова}

Азиатско-Тихоокеанский регион; субрегион Северо-Восточная Азия; Республика Корея; США; Япония; двустороннее сотрудничество; трехсторонние отношения; безопасность; Транстихоокеанское партнерство.

Triangular Relations between the USA, Japan and the Republic of Korea: New Geopolitical Center Composition in the Asia-Pacific Region (Maria Zantovich)

The article is devoted to the trilateral relations between the USA, Japan and the Republic of Korea at the beginning of the XXI century. The three countries share concerns about emerging security issues in the face of China growth and ongoing instability in North Korea. Taking into consideration the functioning of bilateral American alliances with the Republic of Korea and Japan, the unification of the alliances into a single security structure is considered by Washington as a naturally determined step. Three participants are required to make efforts to enhance bilateral relations between Japan and South Korea which are seen as the "weak leg" in the triangular relationship. The project of the Trans-Pacific Partnership appears to be the economic dimension of trilateral cooperation format. In case of successful implementation and accession of South Korea, the Trans-Pacific Partnership will become the largest free trade agreement in 
the Asia-Pacific region with obvious leading role of the United States. The "triangle" of relations is gaining the potential to become a leading geopolitical centre in the Asia-Pacific region.

\section{Key words}

Asia-Pacific region; Northeast Asia subregion; Republic of Korea; USA; Japan; bilateral cooperation; trilateral relations; security; TransPacific Partnership.

Статья поступила в сентябре 2015 г.

\section{Рецензенты:}

Малевич Ю. И. - доктор политических наук, профессор кафедры международных отношений Белорусского государственного университета;

Есин Р. О. - доктор политических наук, профессор кафедры международных отношений Академии управления при Президенте Республики Беларусь. 


\section{МЕЖДУНАРОДНОЕ СОТРУДНИЧЕСТВО}

\section{БЕЛАРУСИ В ОБЛАСТИ ТАМОЖЕННОГО ДЕЛА \\ В УСЛОВИЯХ ФОРМИРОВАНИЯ И РАЗВИТИЯ \\ ЕВРАЗИЙСКОГО ЭКОНОМИЧЕСКОГО СОЮЗА}

\section{Д. В. Коваленок}

старший преподаватель кафедры таможенного дела БГУ, заместитель начальника управления

организации таможенного контроля

Государственного таможенного комитета Республики Беларусь

УДК 339.543(476)

Целью совершенствования международного сотрудничества таможенных органов Республики Беларусь является развитие взаимодействия с зарубежными таможенными службами, способствующего созданию условий для эффективного и взаимовыгодного сотрудничества.

В статье анализируется институт таможенных органов Республики Беларусь в контексте взаимодействия с таможенными службами иностранных государств, а также международными организациями в рамках Евразийского экономического союза.

В белорусской и российской науке теме евразийской интеграции широкое внимание уделяется с недавнего времени. Полезными видятся работы ученых Е. Винокурова, А. Либмана, А. Анисимова, А. Поповой, Е. Балтер, Е. Бессоновой, Е. Достанко, А. Сиротского и др. Вместе с тем вопрос взаимодействия таможенных органов на международной арене освещен недостаточно.

По состоянию на январь 2015 г. договорно-правовую базу многостороннего сотрудничества Республики Беларусь составляют 1658 многосторонних международных договоров в рамках различных международных организаций и интеграционных образований.

Республика Беларусь также располагает развитой договорноправовой базой двустороннего сотрудничества, которую составляют 2219 международных договоров, заключенных со 102 государствами. Так, за 2000-2014 гг. Беларусь подписала 1239 двусторонних международных договоров и других международно-правовых документов, из них более $64 \%$ - за последнее десятилетие (рис. 1). 
На различных стадиях согласования находится более 1200 проектов международных договоров в различных сферах двустороннего сотрудничества. Всего в Секретариате ООН зарегистрировано 126 двусторонних международных договоров Республики Беларусь [14].

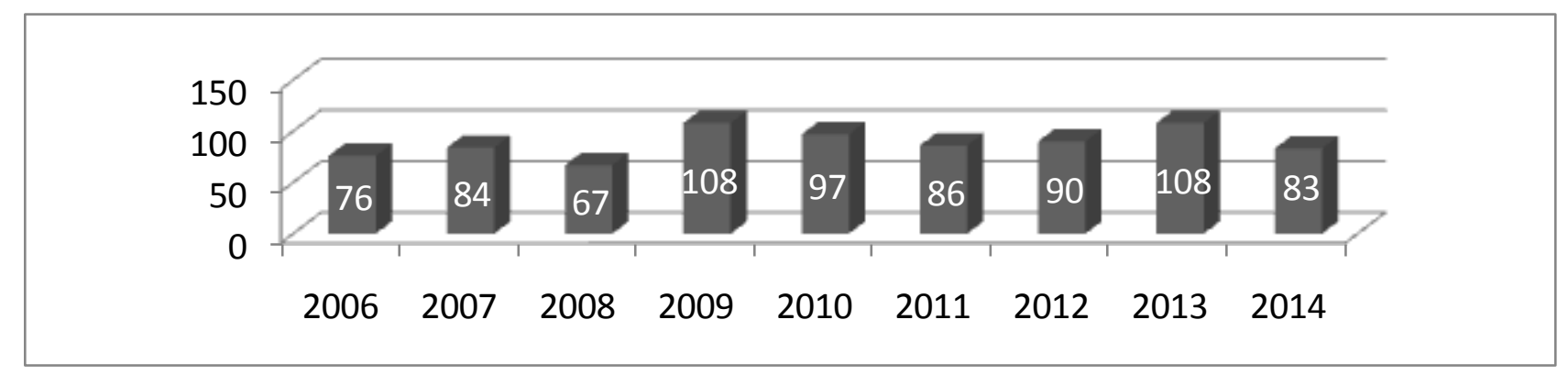

Рис. 1. Количество двусторонних международных договоров и иных международноправовых документов, подписанных Республикой Беларусь [14]

Актуальным направлением развития международных отношений является международное сотрудничество Республики Беларусь в области таможенного дела. С момента обретения независимости белорусским государством заключено 69 международных соглашений, меморандумов, протоколов о сотрудничестве и взаимной административной помощи в таможенных делах с 28 государствами. За последние годы договоренности о взаимопомощи в таможенных делах вступили в силу с Республикой Вьетнам (2011), Турецкой Республикой (2011), Финляндской Республикой (2011), Словацкой Республикой (2012), Республикой Сербия (2013), Монголией (2014), Австрийской Республикой (2014), Китайской Народной Республикой (2015).

На различной стадии разработки находятся 26 международных договоров межправительственного и межведомственного характера о взаимной административной помощи в таможенных делах с такими странами, как Республика Индонезия, Республика Корея, Япония, Республика Союз Мьянма, Исламская Республика Иран, Сирийская Арабская Республика, Республика Албания.

В 1998 г. Беларусь присоединилась к Брюссельской конвенции о карнете АТА (1961) и Стамбульской конвенции о временном ввозе (1990) [18], Брюссельской конвенции о Гармонизированной системе описания и кодирования товаров (1983) [17], в 2000 г. - к Найробийской конвенции «Об оказании взаимной помощи по предотвращению, пресечению и расследованию таможенных правонарушений» (1977), подписанной в рамках Всемирной таможенной организации 
[16], в 2011 г. - к Киотской конвенции об упрощении и гармонизации таможенных процедур (1964) [15].

В целях реализации международных обязательств Республики Беларусь в рамках Таможенной конвенции о карнете АТА для временного ввоза товаров от 6 декабря 1961 г. и Конвенции о временном ввозе от 26 июня 1990 г., а также упрощения порядка временного ввоза товаров в связи с проведением выставок и ярмарок, при временном ввозе товарных образцов и профессионального оборудования и некоторых других категорий товаров в 2014 г. совместно с Белорусской торгово-промышленной палатой (БелТПП) разработаны и внесены в правительство предложения, предусматривающие выдачу карнетов АТА областными отделениями БелТПП.

В 2010-х гг. наметились взвешенные, прагматичные и гибкие взаимоотношения с государствами Западной Европы, что послужило дополнительным стимулом к активизации работы по формированию договорно-правовой базы сотрудничества с Республикой Беларусь в области таможенного дела. Так, урегулированы отношения в сфере таможенного сотрудничества и избежания двойного налогообложения с Австрией, проводятся переговоры о взаимной административной помощи в таможенных делах с Королевством Бельгия, Соединенным Королевством Великобритании и Северной Ирландии, Черногорией, Румынией, Республикой Словеняя, Республикой Болгария, Федеративной Республикой Германия, Французской Республикой, Итальянской Республикой, Швейцарской Конфедерацией.

Наиболее продуктивно сотрудничество в области таможенного дела на постсоветском пространстве. Идею формирования Евразийского союза государств впервые выдвинул президент Казахстана Н. Назарбаев 29 марта 1994 г. во время выступления в Московском государственном университете им. М. В. Ломоносова [2]. В ее основе лежал масштабный проект интеграции независимых государств на качественно новой, прагматичной и взаимовыгодной экономической основе. Не отказываясь от дальнейшего совершенствования Содружества Независимых Государств, новация состояла в создании интеграционной структуры, предусматривающей принятие совместных программ стратегического развития и осуществление регулятивных полномочий в ключевых секторах экономики, а также в политической, оборонной, правовой, экологической, культурной, образовательной сферах. 
Прозвучавшая на пике дезинтеграции евразийская инициатива воспринималась неоднозначно, поскольку задачи укрепления национальной независимости и суверенитета в то время фактически противопоставлялись развитию экономического сотрудничества. Воспринимая интеграцию как рычаг экономического роста и необходимое условие полноценной реализации возможностей политического размежевания постсоветских государств, новые лидеры Беларуси и России А. Лукашенко и В. Путин активно поддержали евразийский проект.

Сближение евразийских государств началось в 1995 г. с подписанием Соглашения о Таможенном союзе Беларуси, Казахстана и России [20]. Тем самым было определено интеграционное ядро государств, которые на протяжении последующих 20 лет не без трудностей и пауз, но последовательно и направленно двигались к созданию Единого экономического пространства (ЕЭП) и Евразийского экономического союза (ЕАЭС). Вскоре к договоренностям таможенной тройки присоединились Кыргызстан и Таджикистан.

В 2000 г. произошел настоящий рывок: пятеркой сопредельных государств создана новая интеграционная структура - Евразийское экономическое сообщество, нацеленное на более тесное сотрудничество на основе унификации нормативной базы и согласования процессов структурной перестройки экономики.

В то же время активизировалась и совместная работа по формированию правовой базы ЕЭП. С 2003 г. к этой работе подключилась Украина, но ее вовлеченность в евразийские интеграционные процессы, к сожалению, вскоре пошла на убыль, и с августа 2006 г. работа по формированию Таможенного союза и ЕЭП (ТС/ЕЭП) сконцентрировалась в рамках Беларуси, Казахстана и России. Кыргызстан и Таджикистан заявили о намерении подключиться к формированию ТС/ЕЭП по мере готовности экономики.

Беларусь, Казахстан и Россия кардинально продвинулись на этом пути. Была сформирована правовая и институциональная база интеграции, определились приоритеты и конкретные направления экономического развития. В октябре 2007 г. лидеры интеграционной тройки подписали Договор о создании Единой таможенной территории и формировании Таможенного союза [7], и начался второй этап интеграции. Тогда же Договором от 6 октября 2007 г. была учреждена Комиссия Таможенного союза - единый постоянно действующий ре- 
гулирующий орган Таможенного союза, основная задача которого обеспечение условий функционирования и развития Таможенного союза.

Катализатором евразийской интеграции послужил в том числе мировой финансово-экономический кризис 2008 г. Повсеместное падение рынков и производства запустило в таможенной тройке интенсивный поиск новых эффективных форматов сотрудничества, которые обеспечили бы устойчивость экономического роста, а также разработку моделей минимизации экономических рисков и сближения национальных экономических стратегий.

«Евразийская мечта», высказанная в 1994 г., стала зримой реальностью уже в 2010-м. Преодолевая последствия кризиса, мир вступает в эпоху взрывного развития интеграционных объединений. Евразийский союз, формирующийся с учетом передовых интеграционных практик, находится на треке этого глобального движения, отвечая на вызовы времени и добиваясь успеха [11, с. 12-15].

Лидеры государств продвигались к согласованным позициям поэтапно, находя баланс интересов и развязки по самым сложным вопросам. 1 января 2010 г. стартовал Таможенный союз Беларуси, Казахстана и России, в рамках которого установлены Единый таможенный тариф и Единая товарная номенклатура внешнеэкономической деятельности, действуют Таможенный кодекс Таможенного союза и Комиссия Таможенного союза, другие международные договоры между сторонами, а также решения Высшего органа Таможенного союза, которому была передана часть полномочий государственных органов сторон.

С 1 июля 2011 г., когда был полностью снят таможенный контроль на внутренних границах и, таким образом, завершено формирование единой таможенной территории, Таможенный союз заработал в полноформатном режиме.

Это обеспечило первую классическую свободу - свободу передвижения товаров на всей единой таможенной территории, где действуют единые механизмы таможенного и внешнеторгового регулирования (таможенно-тарифного и нетарифного), единое правовое поле в области технического регулирования, санитарного, ветеринарного и фитосанитарного контроля, обеспечивающее применение единых перечней подконтрольной продукции и единых требований к ней; единого порядка ввоза, вывоза и перемещения по таможенной террито- 
рии; оформление разрешительных документов по единым формам, которые признаются всеми сторонами.

С 1 января 2012 г. начался следующий этап - формирование ЕЭП, представляющего более высокую ступень интеграции, который предусматривает не только свободное движение товаров и унифицированный торговый режим в отношении третьих стран, но и свободное движение услуг, капитала и рабочей силы, единые правила и принципы в ключевых областях регулирования экономики - в макроэкономике, в сфере конкуренции, в области промышленных и сельскохозяйственных субсидий, транспорта, энергетики.

В ЕЭП были созданы единый рынок в 170 миллионов потребителей, условия для свободного передвижения товаров, услуг, капитала и рабочей силы. С 1 января 2012 г. заработал Суд ЕврАзЭС, обращаться в который по всем фактам, связанным с дискриминацией, нарушением правил конкуренции и равных условий ведения бизнеса, могут не только государства, но и участники экономической деятельности, а с 1 февраля 2012 г. - Евразийская экономическая комиссия, заменившая Комиссию Таможенного союза, - постоянно действующий регулирующий орган Таможенного союза и ЕЭП, которому государства передали часть национальных полномочий.

Участие Беларуси в евразийской интеграции не только стало политическим шагом, но и продемонстрировало экономические выгоды и перспективы от более тесного сотрудничества в регионе. Исследования Евразийского банка развития (ЕАБР) показали, что к концу прогнозного периода - 2030 г. - в Беларуси будут наблюдаться наибольшие положительные эффекты в силу сложившейся экономической структуры, направлений внешнеторговых связей и масштабов экономики [13].

Так, к 2030 г. экспорт в страны ЕЭП составит до 35 \% от суммарного объема ВВП Беларуси, а превышение ВВП в условиях интеграции над вариантом ее отсутствия составит до $15 \%$. Также результаты расчетов показали, что успешность интеграционных процессов будет критически важна для развития белорусской экономики в долгосрочной перспективе, а в структуре производства увеличится доля машиностроительных видов деятельности и пищевой промышленности. Экспертами ЕАБР также отмечено, что Беларусь станет главным относительным выгодополучателем интеграционных процессов на евразийском пространстве. 
Особенность евразийской континентальной интеграции состоит в доминировании в ее структуре интеграции снизу, то есть взаимодействия экономических игроков, за которым следует межгосударственное взаимодействие. В этом отношении современная интеграция в рамках ЕАЭС во многом вписывается в логику волн обмена и периоды максимального развития интеграции в политической сфере, то есть периоды, когда количество политических границ, которые должен был пересечь торговец на пути от Тихого океана к Атлантическому, было минимальным.

Эксперты ЕАБР Е. Ю. Винокуров и А. М. Либманом в монографии о развитии евразийской континентальной интеграции выделили четыре таких периода: 1) эпоха господства Римской империи, династии Хань и парфянской династии Арсакидов (I-II вв.); 2) времена подъема династии Тан и Арабского халифата (VII в.); 3) период возникновения Монгольской империи (XIII в.); 4) Российская империя, Оттоманская империя, династия Цин, Европейский союз, Евразийский экономический союз (XVIII в. - наст. время) [1, с. 224].

С точки зрения логики волн евразийского обмена современная континентальная интеграция в Евразии вписывается в общую структуру развития континента в качестве четвертой волны евразийского обмена. Ее особенность составляет прогресс в сфере транспорта, коммуникаций, трансграничной торговли, что позволяет добиться качественно большего взаимопереплетения отношений в сфере таможенного дела.

Не менее важно то обстоятельство, что, в отличие от более ранних волн, четвертая волна разворачивается в период глобализации и представляет неотъемлемую часть ее развития.

В 2015 г. Беларусь подошла к критически важному этапу региональной интеграции - республика стала членом Евразийского экономического союза, договор о создании которого был подписан президентами Беларуси, Казахстана и России в Астане 29 мая 2014 г. [6]. Фундаментальный договор кодифицировал отрасли экономического сотрудничества, определил институциональную структуру нового интеграционного объединения и правовую систему союза [3]. Обеспечено международно-правовое оформление участия в ЕАЭС Армении и Кыргызстана [4; 5].

Справедливо отметить, что соблюдение ряда новых для нашей страны международных норм и правил, в первую очередь связанных с 
тарифными обязательствами России в рамках Всемирной торговой организации (ВТО), стало необходимостью уже в рамках членства Беларуси в ТС/ЕЭП и к 2015 г. позволило накопить неоценимый опыт проведения как внешней, так и внутренней торговой политики.

Вместе с тем обострение региональной конкуренции, ухудшение экономического состояния основного торгового партнера Беларуси Российской Федерации, а также присоединение к ЕАЭС новых государств (Армении и Кыргызстана) обязывают республиканские органы усилить качество государственного управления в части оценки потенциальных рисков происходящих интеграционных процессов как источников внешних угроз национальной безопасности в политической, экономической, социальной и демографической сферах.

Таким образом, прорывная интеграция на постсоветском пространстве, с одной стороны, создала условия для модернизации евразийских государств и повышения конкурентоспособности их экономик и, с другой стороны, обострила их конкурентное геополитическое противостояние [8].

В последние годы традиционно продуктивным остается сотрудничество в рамках СНГ (подписано 15 международных договоров, из которых 13 вступили в силу) и в двустороннем формате с Российской Федерацией: значительно усовершенствовано сотрудничество в области налогообложения перемещения нефти и нефтепродуктов, строительства на территории Беларуси атомной электростанции.

Участие Республики Беларусь в многосторонних договорах и договорных механизмах позитивно сказывается на ее имидже, а также позволяет создавать рамочные правовые режимы взаимодействия в области таможенного дела с государствами, с которыми не налажено эффективное двустороннее международно-правовое сотрудничество.

ЕАЭС - амбициозный и вместе с тем наиболее реалистичный, опирающийся на четко просчитанные экономические преимущества и взаимные выгоды интеграционный проект в современной Евразии [19].

Это качественно новый уровень экономического взаимодействия сопредельных государств, открывающий широкие перспективы экономического роста, формирующий для интеграционной тройки новые конкурентные преимущества и дополнительные возможности в современном глобальном мире. В ЕАЭС обеспечивается свобода 
движения товаров, услуг, капитала и рабочей силы, а также проведение скоординированной, согласованной или единой политики в отраслях экономики.

Спектр потенциальных вызовов для республики в условиях экономической интеграции в ЕАЭС регулярно изменяется и не может быть определен в рамках компетенции одного государственного органа или института ввиду многовекторности затрагиваемых узкопрофильных вопросов.

В связи с этим в целях нивелирования ущерба для национальной экономики критически необходимой видится ответственная проработка всеми заинтересованными министерствами и ведомствами рисков и угроз по направлениям деятельности, а также своевременное информирование координирующего органа или руководства страны для принятия эффективных управленческих решений.

В 2014 г. евразийскому интеграционному проекту исполнилось 20 лет. Последовательная успешная трансформация евразийского пространства на принципах углубленного таможенного сотрудничества и рыночной экономики с сохранением политической независимости и сложившегося культурного своеобразия суверенных государств продолжается сегодня в противовес мировым кризисным явлениям [9, с. 7].

Несмотря на то что Республика Беларусь активно участвует в международном сотрудничестве, число государств, с которыми она осуществляет внешнеэкономические связи, значительно превышает число государств, с которыми достигнута договоренность о сотрудничестве в таможенных отношениях.

В дальнейшем совершенствование договорно-правовой базы международного таможенного сотрудничества, в том числе с таможенными органами государств, с которыми Республика Беларусь имеет общую границу, остается актуальной задачей таможенных органов.

При заключении международного соглашения необходимо исходить из политического и экономического интереса к государству, из объема торгового оборота, а также грузового и пассажирского потоков между государствами, уровня правонарушений в таможенной cфepe. 


\section{Библиографические ссылки}

1. Винокуров E., Либманом А. Евразийская континентальная интеграция. - СПб, 2012. C. 224.

2. Выступление Нурсултана Назарбаева в МГУ им. М. В. Ломоносова. 29.03.1994 // Молодая Евразия [Электронный ресурс]. - URL : http://yeurasia.org/nazarbaev_msu_1994 (дата обращения : 14.06.2015).

3. Договор о Евразийском экономическом союзе (совершено в г. Астане 29 мая 2014 г.) // Сайт ЕАЭС [Электронный ресурс]. - URL : https://docs.eaeunion.org/sites/storage0/Lists/ Documents/a089f4c6-02da-4461-b033-3f5d122e0020/e57db9f2-9589-4b26-be1e-b1a43862c6ed_ 635375701449140007.pdf (дата обращения : 14.06.2015).

4. Договор о присоединении Кыргызской Республики к Договору о Евразийском экономическом союзе от 29 мая 2014 года // Сайт EAЭС [Электронный ресурс]. - URL : https://docs.eaeunion.org/sites/storage1/Lists/Documents/1ee1568a-2d4c-432b-8709-03cf30bc7b8 2/7710daae-5eec-4e1e-acca-82fb9eff031a_\%D0\%9A\%D0\%B8\%D1\%80\%D0\%B3\%D0\%B8\%D 0\%B7\%D0\%B8\%D1\%8F.pdf (дата обращения : 14.06.2015).

5. Договор о присоединении Республики Армения к Договору о Евразийском экономическом союзе от 29 мая 2014 года // EAЭС [Электронный ресурс]. - URL : https://docs.eaeunion. org/sites/storage0/Lists/Documents/3192b5cd-9395-4f2d-9aef-fc624d3db445/5481e66f-3428-4d99b033-6efc4039cdaf_635486381049072687.pdf (дата обращения : 14.06.2015).

6. Договор о создании Евразийского экономического союза от 29 мая 2014 г. (г. Астана) // ЕАЭС [Электронный ресурс]. - URL : https://docs.eaeunion.org/ru-ru/Pages/AllDocuments.aspx (дата обращения : 14.06.2015).

7. Договор о создании Единой таможенной территории и формировании Таможенного союза от 6 октября 2010 г. (г. Душанбе) // Сайт ЕАЭС [Электронный ресурс]. - URL : https://docs.eaeunion.org/ru-ru/Pages/AllDocuments.aspx (дата обращения : 14.06.2015).

8. Достанко E. A. Основные этапы формирования Таможенного союза и Единого экономического пространства Беларуси, России, Казахстана // Экспертиза : аналит. вестн. Центра междунар. исслед. Белгосуниверситета [Электронный ресурс]. - 2012. - URL : http://www.centis.bsu.by/expertise.html (дата обращения : 23.06.2015).

9. Евразийская экономическая интеграция: цифры и факты // Сайт ЕАЭС [Электронный pecypc]. - URL : http://www.eurasiancommission.org/ru/Documents/EEC_dig_facts1.pdf (дата обращения : 14.06.2015).

10. Евразийский экономический союз: архитектура будущего : годовой отчет 2014 // Сайт ЕАЭС [Электронный ресурс]. - URL : http://www.eurasiancommission.org/ru/ Documents/EEC_ar2014.pdf (дата обращения : 14.06.2015).

11. Евразийский экономический союз : вопр. и ответы : цифры и факты. - М. : Евразийская экономическая комиссия, 2014.

12. Евразийское пространство - пути и механизмы расширения экономической интеграции : материалы кругл. стола (17 окт. 2013 г.) // Евразийский деловой совет [Электронный реcypc]. - URL : http://www.evrazes-bc.ru/news/view/26952 (дата обращения :_14.06.2015).

13. Комплексная оценка макроэкономического эффекта различных форм глубокого экономического сотрудничества Украины со странами Таможенного союза и Единого экономического пространства в рамках ЕврАзЭС (документы телемоста Москва - Киев - Минск - Алматы, 24 янв. 2012) // Сайт Евразийского банка развития [Электронный ресурс]. - URL : http://www.eabr.org/r/research/analytics/centre/projects/ukraine (дата обращения : 14.06.2015).

14. Обзор итогов внешней политики Республики Беларусь и деятельности Министерства иностранных дел в 2014 году // М-во иностр. дел Респ. Беларусь [Электронный ресурс]. URL : http://mfa.gov.by/print/publication/reports/a2973e28e4b86261.html (дата обращения : 14.06.2015). 
15.О присоединении Республики Беларусь к Международной конвенции об упрощении и гармонизации таможенных процедур : Закон Респ. Беларусь от 16 нояб. 2010 г. № 194-3 / Нац. правовой интернет-портал Респ. Беларусь [Электронный ресурс]. - 2010. - URL : http://www.pravo.by/main.aspx?guid=4061\&p0=2010\&p1=264 (дата обращения : 14.06.2015).

16. О присоединении Республики Беларусь к Международной конвенции о взаимном административном содействии в предотвращении, расследовании и пресечении таможенных правонарушений : Указ Президента Респ. Беларусь от 19 июня 2000 г. № 350 / Нац. правовой интернет-портал Респ. Беларусь [Электронный ресурс]. - 2010. - URL : http://www.pravo.by (дата обращения : 14.06.2015).

17.О присоединении Республики Беларусь к Международной конвенции о Гармонизированнной системе описания и кодирования товаров : Указ Президента Респ. Беларусь от 12.08.1998 № 396 / Нац. правовой интернет-портал Респ. Беларусь [Электронный ресурс]. 2010. - URL : http://www.pravo.by (дата обращения : 14.06.2015).

18. О присоединении Республики Беларусь к Таможенной конвенции о карнете АТА для временного ввоза товаров, подписанной в г. Брюсселе 6 декабря 1961 г., а также Конвенции о временном ввозе, подписанной в г. Стамбуле 26 июня 1990 г., с принятием к ней ряда приложений: Указ Президента Респ. Беларусь от 12.01.1998 № 21 // Нац. правовой интернетпортал Респ. Беларусь [Электронный ресурс]. - 2010. - URL : http://www.pravo.by (дата обращения : 14.06.2015).

19. Сиротский А. Н. Объективная основа интеграции // Экспертиза : аналит. вестн. междунар. исслед. Белгосуниверситета [Электронный ресурс]. - 2012. - URL : http://www.centis.bsu. by/expertise.html (дата обращения : 23.06.2015).

20. Соглашение о Таможенном союзе Беларуси, Казахстана и России от 20 января 1995 г. (г. Москва) // Сайт ЕАЭС [Электронный ресурс]. — URL : https://docs.eaeunion.org/ruru/Pages/AllDocuments.aspx (дата обращения : 14.06.2015).

Международное сотрудничество Беларуси в области таможенного дела в условиях формирования и развития Евразийского экономического союза (Дмитрий Коваленок)

Рассматриваются процессы создания современной договорноправовой базы международного таможенного сотрудничества, соответствующей происходящим в государстве процессам, как важной и актуальной задачи таможенных органов Беларуси. Республикой Беларусь заключено более 100 международных договоров в области таможенных отношений. Подчеркивается, что создание Евразийского экономического союза - важнейший шаг на пути реинтеграции всего постсоветского пространства.

\section{Ключевые слова}

Евразийский экономический союз (ЕАЭС); евразийская интеграция; таможенный союз; таможенное регулирование; таможенная служба; международное таможенное сотрудничество. 
International cooperation of Belarus in the field of customs affairs in conditions of the formation and development of the Eurasian Economic Union (Dzmitry Kavalionak)

This article discusses the process of creating of modern juridical base of international customs cooperation, the relevant processes taking place in the country as an important and urgent task of customs authorities of Belarus. Belarus signed more than 100 international treaties in the field of customs relations. It is emphasized that the establishment of the Eurasian Economic Union is an important step towards the reintegration of the postsoviet space.

\section{Key words}

Eurasian Economic Union (EAEU); the Eurasian integration; the customs union; customs regulations; customs service; international customs cooperation.

Статья поступила в мае 2015 г.

\section{Рецензенты:}

Сиротский А. Н. - профессор кафедры таможенного дела Белорусского государственного университета, кандидат исторических наук, доцент;

Есин Р. О. - доктор политических наук, профессор кафедры международных отношений Академии управления при Президенте Республики Беларусь. 


\section{ГДР ВО ВНЕШНЕЙ ПОЛИТИКЕ ВЕЛИКОБРИТАНИИ}

\section{в 1979-1989 гг.}

\section{И. И. Ковяко}

кандидат исторических наук, доиент кафедры всеобщей истории и методики преподавания истории Белорусского государственного педагогического университета УДК 94(410) «1979/1989»

Взаимоотношения Великобритании с ГДР в указанный период составляли часть ее германской политики. После раскола Германии и возникновения ФРГ и ГДР Великобритания была одним из государств «большой четверки», которые несли ответственность за германское урегулирование после Второй мировой войны. 1980-е гг. стали временем актуализации германского вопроса и его окончательного разрешения. Приход к власти в 1982 г. блока ХДС/ХСС и избрание на пост канцлера ФРГ Г. Коля обозначили качественно новый этап в разрешении германской проблемы. Новое правительство ФРГ объявило достижение единства немецкого народа одной из главных задач своей политики. Особое место в германском урегулировании принадлежало Великобритании и лично премьер-министру страны М. Тэтчер.

В начале 1980-х гг. германский вопрос считали в Лондоне открытым, поскольку после Второй мировой войны с Германией не был подписан мирный договор. Раздел Германии в Великобритании рассматривали как промежуточное состояние. Лидеры ГДР выступали с идеей создания единой социалистической Германии. 15 февраля 1981 г. Э. Хонеккер в речи перед партийными функционерами Социалистической единой партии Германии (СЕПГ) заявил: «Придет день, когда рабочие ФРГ перейдут к социалистическому строительству государства. Тогда вопрос об объединении Германии предстанет в новом свете» [33, с. 218]. В 1981-1983 гг. в ГДР разработана концепция «разума и реализма».

Главной внешнеполитической целью провозглашалось сближение со странами Запада, особенно с ФРГ. Данная концепция была раскритикована в СССР. ФРГ стремилась к проведению общегерманских выборов, надеясь на победу партий западной демократии. Анг- 
лия, несмотря на негативное отношение правительства М. Тэтчер к самой идее социализма, была заинтересована в развитии отношений с ГДР. Э. Хонеккер со своей стороны в речи 13 октября 1980 г. в Гере отметил, что ГДР стремится к установлению добрососедских отношений с ФРГ и другими западными государствами [38, с. 524].

Экономическое и культурное направления были главными в англо-восточногерманском сотрудничестве. В Великобритании понимали, что экономика ГДР может сохранять устойчивость только благодаря значительным вливаниям иностранной валюты, ведь западногерманская марка уже в 1979 г. была второй валютой на территории Восточной Германии [42]. Однако английский посол в Берлине П. Фостер охарактеризовал двусторонние отношения в 1979 г. как слабые.

Глава внешнеполитического отдела Политбюро ГДР Г. Аксен не отозвался на предложение британской стороны посетить Лондон в 1979 г., а прибыл только после третьего приглашения в июне 1981 г. В 1980 г. Великобританию посетили министр иностранной торговли и министр тяжелой промышленности ГДР, а 4-6 ноября состоялся визит представителя Форин офис П. Блейкера в ГДР.

Он провел переговоры с министром иностранных дел Восточной Германии О. Фишером, во время которых обсуждались отношения между Востоком и Западом, а также перспективы европейской безопасности и сотрудничества [2, л. 39; 19]. В июле 1980 г. Э. Хонеккер выразил сожаление в связи с тем, что взаимоотношения Великобритании и ГДР «еще не привели к такому широкому единодушию по основным вопросам двусторонних и многосторонних отношений, которое уже установилось между ГДР и Францией» [4, с. 98].

Основной причиной относительно низкого уровня англовосточногерманского политического сотрудничества была поддержка британским правительством планов США по размещению крылатых ракет в Западной Европе.

9 октября 1980 г. произошло резкое ухудшение отношений между ФРГ и ГДР. Восточногерманское руководство приняло решение значительно ограничить число визитов восточных немцев в ФРГ и Западный Берлин.

Для отмены постановления Восточный Берлин требовал от ФРГ признания гражданства ГДР, преобразования постоянных представительств ФРГ на территории Восточной Германии в посольства и рос- 
пуска Центрального бюро регистраций в Зальцгиттере, которое фиксировало акты политического насилия и террора в ГДР [40, с. 205].

В декабре 1981 г. состоялась встреча Э. Хонеккера и канцлера ФРГ Г. Шмидта в окрестностях Вербелинзее. Однако переговоры об упрощении выезда граждан ГДР в ФРГ не принесли результатов. Э. Хонеккер категорически отверг предложение Г. Шмидта увеличить количество граждан, выездных в ФРГ [51, с. 193]. Эти события в Лондоне оценили как «худший кризис в германо-германских отношениях» за последние 10 лет. Решение руководства ГДР британские обозреватели назвали «роковой ошибкой» [28]. Великобритания считала, что Э. Хонеккер стремится поддерживать отношения с ФРГ. 3-5 ноября 1980 г. состоялся визит сотрудника Форин офис Р. Блейкера в Восточный Берлин. В ходе переговоров обе стороны высказались за развитие двусторонних отношений и политического диалога [16]. ГДР, по мнению Лондона, была непосредственно заинтересована в улучшении отношений с ФРГ из-за экономических и финансовых льгот, а также по причине необходимости улучшения имиджа руководства ГДР внутри страны и укрепления международного авторитета Восточной Германии. Основными целями ФРГ было смягчение условий для выезда восточных немцев в ФРГ, а также улучшение материального положения широких слоев населения ГДР.

Экономические отношения между Англией и Восточной Германией развивались медленно и неравномерно. Экспорт Великобритании в ГДР на протяжении 1980 г. не увеличился, и торговый баланс остался неблагоприятным для британской экономики. Английские фирмы не смогли заключить серьезных контрактов с восточногерманскими партнерами, и в 1981 г. Великобританию на рынках ГДР опередили Франция, ФРГ, Австрия и Япония. За 1982 г. экспорт Великобритании в ГДР снизился с 83 до 62 млн ф. ст. [21]. Основу британского экспорта составляли электротехника и транспортное оборудование. ГДР вывозила в Великобританию стальной прокат (25\% восточногерманского экспорта данной продукции), оптику, товары химической промышленности [8, с. 99].

В Лондоне понимали, что политические отношения с ГДР во многом определяют внешнеэкономические приоритеты Восточной Германии. С 1981 г. ГДР была вынуждена увеличить поставки каменного угля и нефти из западных стран, поскольку Польша сократила экспорт каменного угля, а СССР уменьшил на 10 \% поставки нефти в 
ГДР и страны Восточной Европы по льготным тарифам. Великобритания владела значительными запасами каменного угля, а также вела разработки по добыче нефти в Северном море. Очевидно, что политические отношения Великобритании с ГДР предопределяли успех либо неудачу английских экспортеров на рынках Восточной Германии в ближайшем будущем. В историю вошло определение, согласно которому Великобритания не имеет вечных врагов или вечных друзей - она имеет только свои национальные интересы.

В ситуации с Восточной Германией Англия, руководствуясь своими экономическими интересами, вынуждена была признать, что «ГДР - это реальность, стабильная и экономически мощная держава, которая оказывает большое влияние на европейскую политику» [20]. По официальному приглашению палаты лордов и палаты общин британского парламента с 6 по 11 декабря 1982 г. Лондон посетила делегация ГДР. Восточногерманскую группу возглавил член Политбюро ЦК СЕПГ, председатель Народной палаты ГДР Х. Зиндерман. Делегацию из ГДР встречали министр иностранных дел Ф. Пим и работник Форин офис М. Рифкинд, министр торговли П. Рис, один из лидеров социал-демократов Д. Оуэн и теневой министр иностранных дел от партии лейбористов Д. Хейли [1, л. 31]. Обе стороны позитивно оценили развитие отношений между Великобританией и ГДР, было решено усилить контакты между парламентами обеих стран в обсуждении вопросов мира и безопасности. Особую заинтересованность британская сторона выразила в развитии экономических, промышленных и научных связей. Представитель консервативной партии П. Темпл-Морис считал, что визит восточногерманской делегации полезен для создания атмосферы доверия, улучшения отношений Восток - Запад [39]. М. Тэтчер считала, что Великобритании следует присоединиться к ФРГ в призывах к демократизации режима в ГДР.

В 1983 г. власти ГДР дали понять британскому правительству, что хотели бы принять в Восточном Берлине министра иностранных дел Великобритании Д. Хэрда. В этом отношении Англия оставалась «белой вороной» среди стран Западной Европы. И хотя министру торговли Великобритании Ризу удалось заключить очередное соглашение о сотрудничестве во время весенней торговой ярмарки в Лейпциге, баланс англо-восточногерманских отношений изменился в 1983 г. не в пользу Великобритании. Британский экспорт в ГДР снизился на $21 \%$, а восточногерманский экспорт в Англию увеличился 
на $23 \%$ [22]. По этим показателям отношений стран ЕЭС с ГДР Великобритания оказалась в конце списка. Британские политики понимали, что отношения с ГДР никогда не будут близкими по историческим и идеологическим причинам, однако Великобритания, по их мнению, может много дать Восточной Германии в политическом, экономическом и культурном отношении.

Во второй половине 1980-х гг. ГДР постепенно стала утрачивать поддержку Советского Союза во внутренней и внешней политике. После апреля 1985 г. (апрельский пленум ЦК КПСС) и начала перестройки в СССР лидеры ГДР иногда проводили политику, противоположную той, что рекомендовалась советской стороной в ходе межгосударственных и межпартийных контактов. По воспоминаниям М. С. Горбачева, все его осторожные попытки убедить при личных встречах Э. Хонеккера в необходимости реформирования страны и партии «натыкались на глухую стену» [5, с. 162]. Руководитель западногерманских коммунистов Г. Мис, побывавший после апрельского пленума в ГДР, вспоминал, что руководство ЦК СЕПГ получило немало писем с вопросом: а не следует ли и нам подходить к проблемам так же, как и КПСС? Руководство на закрытых активах давало ответ «нет», в целом не следует, хотя по отдельным вопросам новый подход найти нужно. Но, по замечанию Г. Миса, вопросов, по которым нужно было менять подход, так и не удавалось найти [6, с. 57]. Э. Хонеккер в своем кругу не раз говорил, что перестройка в ГДР уже проведена, понимая под этим смену руководства СЕПГ, то есть собственное выдвижение на пост первого секретаря вместо В. Ульбрихта.

В условиях активизации германской политики ФРГ лидеры ГДР, с одной стороны, стремились демонстрировать политическую независимость своего государства. С другой - Э. Хонеккер в сфере германогерманских отношений стремился к большей самостоятельности и независимости от Москвы. Советская периодика в 1983-1984 гг. расставляла акценты на «реваншизме» и «милитаризме» в политическом курсе ФРГ, что не способствовало укреплению дружбы и развитию взаимопонимания СССР с ГДР, скорее наоборот. Впоследствии дисгармония отношений СССР - ГДР, заложенная в период 19831984 гг., внесла свой вклад в непринятие Э. Хонеккером политики перестройки.

Поскольку курс ГДР с 1985 г. в делах внешней политики приобретал все большую самостоятельность, британские аналитики пред132 
вещали рост политического веса ГДР в социалистическом лагере и усиление ее голоса на международной арене. В связи с этим посольство Великобритании в Восточном Берлине рекомендовало британскому правительству продолжать прилагать усилия к развитию отношений с ГДР. В Англии ожидали, что Восточная Германия скоро «расправит крылья», однако берлинский вопрос предпочитали оставлять нетронутым [23].

В апреле 1985 г. состоялся визит министра иностранных дел Великобритании Дж. Хау в ГДР. Вместе с министром иностранных дел ГДР О. Фишером Дж. Хау высказался за интенсивное развитие политического диалога между странами, развитие экономических и культурных связей. Во время беседы Дж. Хау с Э. Хонеккером обе стороны выразили надежду на скорейшее ограничение ядерных вооружений и улучшение отношений Восток - Запад.

Британская сторона провозгласила своей целью добиться значительного сокращения ядерных вооружений с обеих сторон. Дж. Хау также выразил озабоченность по вопросу соблюдения прав человека в ГДР, в частности права на свободу передвижения. Великобритания считала недопустимым создавать искусственные преграды на пути восточных немцев на Запад [47, кол. 448]. В конце встречи восточногерманский лидер передал Елизавете II и М. Тэтчер «наилучшие пожелания и приветы» [59].

Важной внешнеполитической задачей руководства Восточной Германии являлась организация встречи лидера ГДР или министра иностранных дел с британским премьером. Однако М. Тэтчер высказалась категорически против этого, поскольку считала, что такое мероприятие дискредитирует ее политику. Отказ Великобритании от организации подобной встречи затруднил интенсификацию политического сотрудничества двух стран. О. Фишер и член Совета министров ГДР Г. Райхельт посетили Лондон 18 ноября 1986 г. и 2 июля 1987 г. В ходе переговоров представители обеих стран высказались за политику разоружения и развитие диалога между НАТО и ОВД. О. Фишер за время визита в Лондон убедился в тщетности попыток организации личной встречи с М. Тэтчер.

Несмотря на то что с 1985 г. между МИД двух государств были установлены регулярные контакты, к 1987 г. двусторонние отношения характеризовались лишь определениями «стабильные» и «скромно удовлетворительные» [24]. 
Британская сторона считала, что для их дальнейшего развития необходимо использование политики кнута и пряника. Великобритания настороженно относилась к развитию диалога ФРГ с социалистическими странами, однако британское агентство новостей «Рейтор» охарактеризовало визит Э. Хонеккера в ФРГ 6-11 сентября 1987 г. как «историческое событие, которое ознаменовало собой большой прорыв в направлении нормализации отношений между двумя государствами» [54]. Британское посольство в ГДР было разочаровано отношениями Э. Хонеккера с М. С. Горбачевым и слабой восприимчивостью ГДР идей перестройки и нового мышления.

Экономические отношения двух стран продолжали развиваться, в 1988 г. британский экспорт в ГДР вырос на 20\%, но торговый баланс по-прежнему складывался в пользу Восточной Германии. Главными внешнеторговыми партнерами ГДР на Западе, кроме ФРГ, были Франция, Великобритания и Италия. Секретарь МИД Великобритании М. Меллор совершил визит в ГДР 12-16 марта 1988 г. Он встретился с рядом политических деятелей Восточной Германии и посетил Лейпцигскую ярмарку. На ярмарке были представлены товары более 140 британских производителей, 66 из них получили золотую медаль. По итогам визита М. Меллор пришел к выводу, что для британских фирм существуют «огромные возможности» развития на рынках ГДР [49, кол. 1073].

Министр торговли Восточной Германии доктор Байль дважды в 1988 г. посетил Лондон, демонстрируя заинтересованность немецкой стороны в развитии торговых отношений с Великобританией [25]. Однако политические отношения двух государств все еще не удовлетворяли восточногерманскую сторону. М. Тэтчер не считала возможной личную встречу с Э. Хонеккером, а в Восточной Германии этому политическому шагу придавали особое значение. Руководство ГДР демонстративно выражало британскому посольству свое разочарование уровнем политических взаимоотношений между двумя государствами.

Британские аналитики констатировали, что давление по данному вопросу будет расти по мере того, как лидеры других европейских государств (в их числе президент Франции Ф. Миттеран) продолжат свой диалог с Э. Хонеккером. Посол Великобритании в ГДР Н. Брумфилд отмечал, что коммерческие интересы Англии в Восточной Германии могут серьезно пострадать, если руководство СЕПГ придет 
к выводу о «наименьшей предпочтительности» восточных немцев для британских политиков из всех народов Европы [25].

С конца 1987 г. британское посольство в Восточном Берлине все чаще стало указывать на рост оппозиционных настроений внутри ГДР. Основной причиной внутриполитических проблем Восточной Германии в Великобритании считали недоверие руководства ГДР к политике М. С. Горбачева, к принципам перестройки и гласности. Восточногерманская оппозиция формировалась главным образом под крышей евангелической церкви. Там собирались различные группы по защите прав человека и гражданина, проводили собрания экологические и пацифистские организации. Церковные структуры издавали оппозиционные газеты и журналы под маркой «для внутрицерковного пользования» [51, с. 240]. В ответ служба госбезопасности ГДР организовала массовые преследования оппозиционеров и установила более жесткий контроль за деятельностью протестантской церкви. Депутаты палаты общин британского парламента осудили действия восточногерманского руководства и призвали к выполнению обязательств, взятых на себя правительством ГДР после подписания Хартии по правам человека ООН и Заключительного акта в Хельсинки [48, кол. 657].

В 1989 г. Н. Брумфилд характеризовал ГДР как государство, стабильность которого влияет на стратегические интересы Великобритании. Торговый баланс в этом году продолжал сохраняться в пользу ГДР, хотя британский экспорт в Восточную Германию возрос. Наибольший прогресс ожидался в области распространения английского языка и подготовки управленческого состава ГДР. Смещение М. Хонеккер с поста министра образования ГДР открывало огромные возможности для усиления британского влияния на молодое поколение управленцев и потенциальных политических лидеров Восточной Германии. Особое внимание уделялось преподаванию английского языка, который, по прогнозам Н. Брумфилда, с 1990 г. должен был заменить русский язык в качестве первого иностраного для восточных немцев [26].

В ответ на актуализацию германского вопроса со стороны ФРГ правительство Восточной Германии решило представить мировому сообществу свои соображения по этой проблеме. В интервью 8 июня 1985 г. Э. Хонеккер выразил точку зрения, что благодаря Берлинской стене стало возможным совещание в Хельсинки, международное при- 
знание ГДР, создание СБСЕ. Стена, по его мнению, исчезнет тогда, когда уйдут в прошлое причины, ее породившие [38, с. 527]. В ноябре 1986 г. советник Э. Хонеккера В. Зайферт издал книгу «Вся Германия - перспективы воссоединения». В ней автор выразил уверенность в том, что объединенная Германия будет служить только интересам СССР и социалистического блока [40, с. 212]. Как уже отмечалось, Великобритания не считала германский вопрос закрытым, поскольку после Второй мировой войны с Германией не был подписан мирный договор. В январе 1989 г. Дж. Хау заявил, что Берлинская стена - это «реликт холодной войны, который должен пасть в ходе развития европейских мирных процессов» [57, с. 129]. В такой ситуации Лондон считал необходимым развивать отношения с двумя немецкими государствами, не отказываясь при этом от критики в адрес политического режима в ГДР.

Однако правительство М. Тэтчер никогда бы не согласилось с объединением Германии по советской модели. Британский МИД после 1945 г. продолжал рассматривать территорию ГДР и Восточного Берлина как часть западного мира. Делами Восточной Германии в Форин офис занимался отдел не Восточной, а Западной Европы [35, c. 63].

Особое внимание Великобритании к германской проблеме отразилось в серии визитов членов королевской семьи в Западный Берлин. Во второй половине 1980-х гг. город посетили королева Елизавета II, принц Чарльз и принцесса Диана.

К 1989 г. экономический и политический кризис в Восточной Германии достиг апогея. В ответ на просьбу ГДР об экономической помощи ФРГ заявила, что таковая будет оказана лишь при условии, что на территории ГДР установится демократический строй западного образца. В ответ весной 1989 г. Э. Хонеккер заявил, что Берлинская стена простоит еще 100 лет. Поворотной точкой в развитии кризиса стало начало массового бегства жителей из ГДР через Венгрию и Австрию. С начала 1989 г. канцлер ФРГ Г. Коль и министр иностранных дел Г.-Д. Геншер провели ряд встреч с венгерскими политиками, уговаривая их открыть восточным немцам ворота на Запад.

Для достижения цели лидеры ФРГ использовали и «экономический пряник» - в феврале 1989 г. правительство Венгрии в ходе секретных переговоров с ФРГ получило кредит в размере 500 млн марок ФРГ фактически в ответ на согласие открыть границу. Требования 
ГДР к Венгрии о сохранении на этой границе прежнего порядка были отклонены. После 2 мая тысячи восточных немцев транзитом устремились в ФРГ через Венгрию, куда жителям ГДР даже не требовалось визы.

В Великобритании наилучшим способом разрешения германской проблемы считали демократизацию ГДР и сохранение двух немецких государств. Объединенная Германия представлялась Лондону слишком богатой и могущественной. Поэтому британская сторона стремилась поощрять реформы в ГДР и надеялась на стабилизацию ситуации. М. Тэтчер в сентябре прибыла в Москву, чтобы объяснить М. С. Горбачеву свою позицию по вопросу германского единства. Говоря не только за себя, но и за Ф. Миттерана, М. Тэтчер призвала к осторожности и последовательной демократизации ГДР [3, с. 88-90]. 20 сентября министр иностранных дел Великобритании Дж. Мейджор посетил Бонн. В ходе переговоров с Г.-Д. Геншером он избегал термина «воссоединение», однако отметил, что «немцы имеют право на самоопределение». Массовое бегство граждан ГДР на Запад Дж. Мейджор расценил как «знак привлекательности западной демократии» [35, с. 91].

7 октября 1989 г. во время празднования 40-й годовщины образования ГДР в Лейпциге разыгрались побоища между силами безопасности и демонстрантами, требовавшими демократизации политического режима в стране. На празднованиях присутствовал и М. С. Горбачев, откуда он вернулся весьма обеспокоенным. Страна, по его воспоминаниям, напоминала кипящий котел с плотно закрытой крышкой [5, с. 162].

На замечания М. С. Горбачева, что «того, кто опаздывает, наказывает жизнь», Э. Хонеккер лишь раздраженно указал на внутренние проблемы и дефицит товаров в самом СССР [13, с. 442]. В октябре 1989 г. в британских СМИ появились критические замечания в адрес Бонна, который под предлогом «нежелания дестабилизации обстановки в ГДР» мало сотрудничал с оппозицией. На собрании консервативной партии один из государственных министров В. Вальдегрейв высказал идею, что «однажды население ГДР с полным правом может решить связать свою судьбу с ФРГ» [35, с. 93]. М. Тэтчер в беседе с М. С. Горбачевым 9 октября высказалась «решительно против объединенной Германии», однако отметила, что она «не может этого сказать ни у себя дома, ни в НАТО» [11, с. 215]. 
18 октября в условиях сильнейшего политического кризиса Э. Хонеккер вынужден был уйти в отставку со всех руководящих постов. Его соратники, возглавляемые Э. Кренцом, оказались не в состоянии стабилизировать положение. В ФРГ нового лидера ГДР воспринимали как очередного диктатора, действиями которого из-за кулис руководит бывший генеральный секретарь [41, с. 171]. В Великобритании Э. Кренца рассматривали как прямого ставленника Э. Хонеккера с весьма схожими традициями управления и образом мыслей. Когда в своей вступительной речи Э. Кренц заговорил о желании внутренних и внешних врагов ГДР реформировать ее по капиталистическому образцу, в Лондоне окончательно стали считать нового лидера ГДР «человеком вчерашнего дня» [29].

Вопрос возможного объединения двух немецких государств продолжал обсуждаться на страницах британской прессы. Настоящей политической бомбой стала статья журналиста «Таймс» К. О’Брайена «Опасайтесь возрождения рейха», вышедшая в свет 31 октября 1989 г. Автор выражал уверенность в том, что объединенная Германия рано или поздно преобразуется в националистический Четвертый рейх, где будут господствовать расистские идеи, немцев научат чувствовать не вину, а гордость за холокост и в каждом немецком городе установят памятник А. Гитлеру. К. О’Брайен предсказывал новые преследования евреев, разрыв отношений ФРГ с Израилем и поддержку Палестины в ближневосточном конфликте. Статья вызвала бурное обсуждение на страницах «Таймс». Абсолютное большинство не поддержало идеи К. О’Брайена. Другой журналист «Таймс» Б. Левин назвал Германию «образцом демократии» и выразил уверенность, что в случае вхождения ГДР в западный блок, свобода и демократия в Европе только укрепятся [35, с. 95]. Однако многие в Великобритании сходились в том, что объединение Германии ослабит возможности Лондона влиять на европейскую политику и нарушит сложившийся баланс сил. Между тем в Форин офис считали, что открытое противостояние объединительному процессу может привести к серьезному конфликту с ФРГ и США [56, с. 21].

Нараставшее с мая 1989 г. бегство жителей ГДР в ФРГ через Венгрию и Чехословакию создавало трудности для этих республик, поэтому 7 ноября руководство СЕПГ решило открыть на германо-германской границе проход через Берлинскую стену для выезда в Западный Берлин и ФРГ граждан ГДР, которые решили уехать на постоян- 
ное жительство. Визовый режим при этом не отменялся - все граждане ГДР перед выездом из страны должны были оформить визу. МИД ГДР запросил у посла СССР мнения советского руководства по поводу либерализации режима границы. Был получен ответ, что регулирование режима границ - внутреннее дело ГДР [7, с. 78]. Советникпосланник посольства СССР в Берлине И. Максимычев отмечает, что все вопросы, затрагивающие судьбу Западного Берлина, должны были приниматься после консультаций с США, СССР, Великобританией и Францией, подписавшими Четырехстороннее соглашение 1971 г. Однако в данном случае руководство ГДР взяло всю ответственность на себя [10, с. 147]. Решение о либерализации режима границ должно было поступить в печать 10 ноября, однако проводивший вечернюю телевизионную пресс-конференцию Г. Шабовски не был в курсе деталей. На последовавший вопрос журналиста «Когда этот проект вступает в силу?» Г. Шабовски ответил: «Насколько мне известно незамедлительно, прямо сейчас» [9, с. 129-130].

Вечером 9 ноября 1989 г. жители столицы и пригородов ринулись в Западный Берлин, причем абсолютное большинство - из любопытства. Пограничные службы не смогли справиться с наплывом людей и в итоге открыли пропускные пункты. Толпа хлынула в Западный Берлин без оформления документов. Руководство Западного Берлина готовилось к подобному развитию событий. Еще 29 октября Г. Шабовски в беседе с мэром Западного Берлина В. Момпером говорил о намерении правительства ГДР предоставить своим гражданам свободу передвижения [14, с. 96].

После «ночи свидания» ФРГ и ГДР с 9 на 10 ноября 1989 г. в социалистической части Германии общественно-политическая обстановка стала быстро меняться. Символом этого стала ликвидация Берлинской стены. Г. Коль назвал этот день великим в германской истории и добавил, что «мы будем и дальше оставаться единой нацией с единым происхождением. Шаг за шагом мы должны найти путь в наше общее будущее» [44]. Однако идее объединения Германии противился Э. Кренц, который продолжал рассматривать возможность существования ГДР как «социалистической альтернативы развития Германии» [45], указывая, что правительство будет всячески содействовать развитию солидарности на восточногерманских землях, защищать свободы личности, развивать экономику и охранять окружающую среду. 
Первым, кому позвонил Г. Коль 10 ноября вечером, была М. Тэтчер. Канцлер полагал, что разговор будет тяжелым, но из Лондона возражений не последовало, премьер-министр Великобритании заявила, что она уже «в курсе». М. Тэтчер приветствовала падение Берлинской стены как «великий день свободы», но при этом отмечала, что на данном этапе еще слишком рано говорить о полном объединении Германии. Перед объединением страны, по мнению премьер-министра, необходимо шаг за шагом учредить в ГДР многопартийный демократический строй. Это, на ее взгляд, помогло бы приостановить поток переселенцев и помочь гражданам ГДР перестроить государственную систему. Таким образом, западная модель может продвинуться на Восток и без объединения Германии. М. Тэтчер полагала, что любой стране Восточной Европы понадобится минимум 10-15 лет для установления демократии и преодоления экономических трудностей. Только после завершения данного периода она считала уместным рассматривать другие варианты взаимодействия с этими государствами [53].

16 ноября 1989 г. состоялся визит английского министра иностранных дел Д. Хэрда в Берлин. Глава Форин офис заявил, что дело реунификации не требует немедленного разрешения. Оно не стоит на повестке дня, так как сами реформаторы в ГДР его туда не вынесли. Д. Хэрд также высказался против изменения статуса Берлина [35, с. 103]. По мнению Д. Хэрда, объединение Германии также не могло рассматриваться в качестве ближайшей перспективы. Великобритании нужна только такая Германия, которая будет основана на демократических ценностях и принципах ФРГ, т. е. станет полноправным членом ЕС и НАТО. Министр обороны Т. Кинг поддержал премьера и высказался за развитие событий «шаг за шагом». Бывший посол Великобритании в Бонне Дж. Буллард также не считал необходимым торопить события. Лидер лейбористов Н. Киннок приветствовал «падение железного занавеса», однако вместе с тем предупреждал о возможных проблемах, связанных с массовым перемещением людей с Востока на Запад [50]. Дж. Кауфман (глава МИД в теневом кабинете), посетив Берлин 11 ноября, пришел к выводу о том, что воссоединение Германии не стоит на повестке дня [17]. Британские СМИ сообщали, что ни СЕПГ, ни восточногерманская оппозиция не хотят объединения Германии. Однако они признавали, что широкие массы восточных немцев с каждым днем все более настойчиво требуют воссо- 
единения страны и введения на территории ГДР западногерманской марки. Форин офис осознавал, что невозможно бесконечно поддерживать искусственное разделение Германии [56, с. 23].

Сразу после падения Берлинской стены в Лондоне было принято решение о создании в Бонне Объединенного разведывательного комитета (отдел MI6). Его задачами были сбор информации и регулярные доклады о развитии событий в Восточной Европе и возможности объединения Германии. Озабоченность Великобритании углублялась опасениями того, что США могут вывести свои войска из ФРГ. М. Тэтчер дала понять, что она вовсе не спешит увидеть объединенную Германию и не собирается отзывать из ФРГ Британскую Рейнскую армию. По ее убеждению, «если бы США остались в Европе после Первой мировой войны и НАТО существовало бы уже тогда, то Второй мировой войны не случилось бы» [50]. Недоверие к немцам стало неотъемлемой частью внешнеполитического мышления М. Тэтчер со времен Второй мировой войны. «Мы прошли войну, и мы очень хорошо знаем, что представляют из себя немцы ... и как, в основном, не меняется национальный характер», - заявила она вскоре после падения Берлинской стены [15, с. 104].

Вместе с тем М. Тэтчер выступала категорически против скорейшего создания ЭВС (экономического и валютного союза в Европе), в чем ей противостояли французский президент Ф. Миттеран и президент Европейской комиссии Ж. Дэлор. М. Тэтчер верила, что последние события в Берлине приведут к тому, что ФРГ вместе с Великобританией сумеют сдержать порывы Франции к незамедлительному образованию ЭВС. На саммите ЕЭС в Штутгарте М. Тэтчер выразила уверенность, что население ГДР не захочет, ликвидировав «монолитные структуры» коммунизма, причислять себя к другому монолитному образованию, хотя бы и западному [45]. Однако 14 ноября министр финансов ФРГ Т. Вайгель заявил, что события в ГДР «не охладили энтузиазм ФРГ к созданию валютного союза в Западной Европе» [37]. Противостояние кабинета М. Тэтчер образованию ЭВС и другим мероприятиям ЕС вызвало негативную реакцию лейбористов. Их представитель Г. Форд указывал на то, что правительство, возглавляемое М. Тэтчер, «отгородилось и провалило много проектов ЕЭС, направленных на улучшение жизни рядовых жителей страны. Британия в годы этого правительства превратилась в слабого, толстого, грязного человека Европы» [52]. 
М. Тэтчер изначально исходила из того, что СССР решительно выступит против объединения Германии на условиях ФРГ. Ликвидацию ГДР она рассматривала как «дискредитацию коммунизма», к тому же были опасения насчет возможности прихода к власти в объединенной Германии правительства левее центра, которое впоследствии будет выступать за нейтральный безъядерный статус Германии. После падения стены М. Тэтчер больше других западных политиков беспокоилась о возможных трудностях, которые это событие может доставить М. С. Горбачеву в СССР. Она утверждала, что без «дальнозоркости и мужества» советского лидера современные процессы в Центральной и Восточной Европе были бы невозможны [31]. Несмотря на строгий курс интеграции Германии в НАТО, она неоднократно подчеркивала, что Запад не должен делать ничего такого, что привело бы к дестабилизации ОВД, так как это «может доставить огромные неприятности Горбачеву, который, собственно, и вдохновил современные процессы в Восточной Европе» [30]. М. С. Горбачев разделял позицию М. Тэтчер по германскому вопросу и даже в ноябpe 1989 г. не считал, что вопрос об объединении Германии назрел и приобрел актуальность [6, с. 79].

Неоднозначной была реакция британской общественности и политических партий. В консервативных СМИ начались дебаты между сторонниками и противниками объединения Германии. Умеренные консерваторы призывали к преодолению раскола Европы, расширению ЕС на Восток.

Германию они рассматривали в качестве краеугольного камня европейского единства. Депутат консервативной партии и глава британо-германской группы в парламенте Б. Брейн считал объединение Германии неизбежным. Однако он призывал сделать новую Европу достаточно гибкой для того, чтобы затем принять в свой состав и страны Восточной Европы.

Сторонники германского единства считали неоправданными опасения возрождения немецкого нацизма и милитаризма. Третий рейх стал возможен в том числе из-за тяжелых условий Версаля, а после 1945 г. страны Запада избрали иной путь обращения с побежденной Германией, помогли ей превратиться в сильное и процветающее государство. Идеи о необходимости создания союза с Францией для того, чтобы уравновесить мощь объединенной Германии, сторонники немецкого единства считали устаревшими. 
В Великобритании понимали, что у ГДР нет демократических традиций, поэтому объединенную Германию необходимо «растворить» в Европе, а она поможет западным странам проникнуть на рынки восточноевропейских стран. Умеренные консерваторы считали, что Великобритания должна бороться за ускорение европейской интеграции и включение единой Германии в состав объединенной Европы [34]. Правые консерваторы относились к идее германского единства более настороженно. Они призывали к сохранению американских и британских вооруженных сил на территории Германии и требовали зафиксировать военную мощь ФРГ на уровне, приемлемом для ее соседей. Доктор В. Паркер из университета в Глосе, анализируя геополитическую концепцию $\mathrm{X}$. Маккиндера о ключевой роли Восточной Европы на пути к мировому господству, считал недопустимым установление в данном регионе немецкой экономической гегемонии. С помощью США и Великобритании Восточная Европа, по его мнению, должна стать экономически жизнестойкой зоной, независимой от России либо Германии [46].

Лейбористы, по сравнению с консерваторами, высказывались более определенно в пользу объединения Европы. Они рассматривали это как необходимое следствие объединения Германии. Лидер лейбористской партии Н. Киннок считал, что падение стены таит в себе большие возможности, но вместе с тем и большие вызовы. Массовое передвижение людей на Запад может привести к дестабилизации обстановки. Больше всего лейбористские круги опасались того, что Германия может избрать собственный путь развития, отказавшись войти в ЕС и НАТО. Лейбористы в парламенте упрекали М. Тэтчер в отсутствии видения нового образа Европы и стремлении притормозить европейскую интеграцию. Они выступали за создание федеративной Европы и видели Германию в качестве лучшего образца для европейского будущего [55]. Партия Н. Киннока признавала, что объединение Германии повлечет за собой серьезные проблемы в реорганизации мировых экономических и военно-политических структур. Лейбористы считали, что объединение Германии в конечном итоге изменит лицо Европы к лучшему. В открытии Берлинской стены и движении Германии к единству они видели особую заслугу лично М. С. Горбачева.

Наиболее оптимистично к идее объединения Германии отнеслись либералы. Профессор Д. Чайлдз из Ноттингемского универ143 
ситета выразил уверенность в том, что демократическое правительство может возникнуть в ГДР в течение года. Он рассматривал объединенную Германию как фактор создания процветающей Европы. По его мнению, после разрешения германского вопроса опасная ситуация в центре Европы исчезнет и будет положено начало новому европейскому порядку. Либералы выражали полную уверенность в исчезновении нацизма и милитаризма в ФРГ, полагая, что «немцы стали европейцами». Падение Берлинской стены стало для них «триумфом Германии и Европы» [58].

Коммунистическая партия Великобритании пыталась сыграть на разногласиях и опасениях консерваторов для того, чтобы еще более накалить ситуацию по германскому вопросу в правительстве, парламенте и в обществе в целом. Лидер КПВ Г. Макленнан открыто заявил, что в Великобритании многие боятся объединенной Германии как «серьезного противника в капиталистическом мире». С точки зрения коммунистов, для Западной Европы было бы лучше, если бы единая Германия последовала за СССР, найдя в своей политике больше общего с М. С. Горбачевым, чем с М. Тэтчер или Ф. Миттераном [36].

Осознавая серьезность и важность исторического момента, лидеры США, СССР, Франции и Великобритании на начальном этапе избегали жестких критических формулировок при обсуждении германского вопроса. Падение Берлинской стены было неожиданностью как для ряда политических лидеров в ФРГ и ГДР, так и для руководств держав-победительниц. С момента падения Берлинской стены должно было пройти определенное время, за которое лидеры стран выработали бы свое видение проблемы и тактику действий. Единственное, в чем сходились на словах руководители всех заинтересованных стран, было то, что процессы, набирающие силу в ГДР, не должны привести к дестабилизации остановки в Европе. Поэтому от всех политиков требовалось максимум осторожности и осмотрительности в высказываниях и действиях относительно германской проблемы.

В условиях такой негласной договоренности полной неожиданностью стало выступление 28 ноября 1989 г. Г. Коля в бундестаге со своим планом объединения Германии («10 пунктов»), который включал три основные положения: подписание договорного союза ГДР с ФРГ, создание конфедеративных структур, а затем образование федерации. Торопливость Коля была не случайной. На созванном 18 ноября в Париже саммите Европейского сообщества царила ледяная ат- 
мосфера. Правительству ФРГ дали четко понять, что свои планы по объединению они должны увязать с процессом европейской интеграции и уважать сохраняющуюся четырехстороннюю ответственность за Германию в целом.

Премьер-министр Великобритании занимала наиболее жесткую позицию, заявив, что «воссоединение не стоит на повестке дня», а также что Хельсинкский Заключительный акт четко зафиксировал нерушимость границ, включая границу между ГДР и ФРГ [12, с. 68]. М. Тэтчер определила, что немцы должны согласовать процесс объединения с НАТО и учесть Хельсинкские соглашения. Важнейшим из аспектов объединения М. Тэтчер считала вопрос безопасности, которая должна быть обеспечена прежде всего четырьмя державами-победительницами вместе с двумя Германиями.

Реакция политических лидеров «четверки» на выступление Г. Коля была неоднозначной. Позиция Великобритании во многом определялась позицией США, поэтому М. Тэтчер изначально интересовала реакция Вашингтона. 29 ноября 1989 г. в Белом доме госсекретарь США Дж. Бейкер выступил с докладом на тему «К вопросу о воссоединении Германии», где изложил четыре принципа, на которых американское правительство собиралось строить свою германскую политику:

1) право немецкого народа на самоопределение и самостоятельный выбор формы государственного устройства, будь то конфедерация, единое федеративное государство либо что-то другое;

2) в случае объединения Германия должна стать полноправным членом блока НАТО и, войдя в состав ЕС, следовать в фарватере европейской интеграции;

3) процесс урегулирования в отношении Германии должен протекать постепенно, мирно, шаг за шагом, в интересах общеевропейской стабильности и безопасности;

4) по вопросу границ основополагающим документом должны стать Хельсинкские соглашения о послевоенном устройстве мира. При этом не исключалось также изменение границ мирными средствами по обоюдному согласию сторон [18, с. 574].

Первый пункт американского подхода М. Тэтчер оставила без комментариев, она выразила согласие с третьей и четвертой позицией, а также с идеей включения объединенной Германии в НАТО. По вопросу превращения объединенной Германии в двигатель европей- 
ской интеграции М. Тэтчер не могла согласиться, поскольку была в принципе против углубления политической интеграции Европы. Впоследствии позиция Дж. Буша по вопросу европейской интеграции была противопоставлена в СМИ «брюггской» позиции М. Тэтчер. Для разрядки внезапно возникшей напряженности американский президент в беседе с британским премьер-министром пояснил, что имел в виду прежде всего экономическую интеграцию Европы, а не политическую. Однако в любом случае Великобритания не могла больше рассчитывать на поддержку США в сдерживании процесса германского объединения.

На саммите стран - участниц блока НАТО М. Тэтчер настаивала на том, что ход воссоединения должен растянуться на 10-15 лет. Именно столько времени, по ее мнению, требовалось для преобразования общественно-политической структуры ГДР на демократических началах и проведения в бывшей республике ряда экономических реформ. Германский процесс также должен решаться в тесном сотрудничестве лидеров «четверки» с правительствами ФРГ и ГДР. М. Тэтчер особо подчеркивала роль М. С. Горбачева в процессе демократизации общественной жизни в странах социалистического лагеря и призывала западных лидеров к осторожности и поступательности в разрешении германского вопроса. Неосмотрительные действия западных стран, по мнению премьера, могли создать критическую ситуацию для М. С. Горбачева в Москве и даже привести к его смещению и замене на другого политического лидера, у которого могло быть свое, вероятно куда менее терпимое, отношение к происходящему в ГДР [53]. Сыграло свою роль также личное отношение М. Тэтчер к М. С. Горбачеву: начиная с момента первой встречи в 1984 г. у лидеров двух стран сложились «особые отношения». В свое время М. С. Горбачев называл М. Тэтчер то «боевой политической подругой», то «нахальной бабой», когда та принималась активно пропагандировать тэтчеризм в Москве. Однако даже после своего ухода в отставку М. Тэтчер сохранила теплые воспоминания о советском лидере и даже настойчиво добивалась отправки международной делегации в Форос к блокированному там М. С. Горбачеву в 1991 г.

29 ноября 1989 г. в Лондон прибыл Г.-Д. Геншер. Во время встречи с М. Тэтчер и Д. Хэрдом он подчеркнул преданность ФРГ НАТО и ЕС. М. Тэтчер по-прежнему сохраняла настороженное отношение к идее германского единства и холодно восприняла выступ- 
ление канцлера с «10 пунктами». Она продолжала настаивать на необходимости сохранения статуса-кво в Европе [35, с. 106]. По итогам встречи Г.-Д. Геншер сделал вывод, что из стран западного лагеря труднее всего будет договориться с Великобританией. Однако в ФРГ понимали, что если заручиться поддержкой Вашингтона и Парижа, Лондон будет вынужден согласиться и принять германское единство $[32$, с. 676]. Посол Великобритании в ФРГ К. Маллаби сообщал, что на фоне выступлений американской и французской сторон британская «сдержанность по отношению к “10 пунктам" кажется Бонну особо заметной» [56, с. 24]. В ноябре 1989 г. стало очевидно, что США не собираются сдерживать процесс объединения Германии.

Таким образом, в 1980-е гг. политика Великобритании в отношении ГДР и по германскому вопросу в целом определялась национальными экономическими и военно-политическими интересами страны. Британское руководство учитывало геополитические реалии на континенте и стремилось строить выгодные для себя отношения с двумя немецкими государствами. Отношения Великобритании с ГДР строились на основе экономических интересов двух государств и имели двойственный характер, поскольку руководство СЕПГ негативно относилось к военно-политическому курсу Англии в Европе и на этом основании сдерживало углубление экономических связей.

Несмотря на реалистичный подход к германской проблеме и признание существования двух немецких государств, Великобритания не считала германский вопрос окончательно решенным, так как после Второй мировой войны с Германией не был подписан мирный договор. Хотя правительство М. Тэтчер не рассматривало германскую проблему как актуальную, однако и не отрицало, что однажды ценности западной демократии могут установиться и по другую сторону Берлинской стены. Во второй половине 1980-х гг. отношения Великобритании и ГДР оставались на невысоком уровне. Особое внимание уделялось развитию экономических и культурных связей. В Лондоне внимательно следили за углублением кризисных явлений в ГДР, поскольку считали Восточную Германию сферой британских стратегических интересов.

После падения Берлинской стены руководство Великобритании заняло сдержанную позицию, оценив перспективу объединения двух германских государств как неактуальную и неосуществимую в ближайшее время. Однако уже к декабрю 1989 г. стало очевидно, что 
ФРГ и США заинтересованы в форсировании объединительного процесса. Из государств «большой четверки» неопределенными оставались лишь позиции Лондона и Парижа. В деле сдерживания объединения Германии из стран западного блока Англия могла рассчитывать только на Францию. Предположения М. Тэтчер о возможности создания эффективной англо-французской оси основывались на присущем Франции историческом чувстве угрозы со стороны соседней сильной Германии. Однако ввиду геополитических интересов Франции в Европе (стремление к расширению и углублению интеграционных процессов и «привязыванию» объединенной Германии к институтам НАТО и ЕС) британский проект «оси» так и не был реализован на практике.

\section{Библиографические ссылки}

1. Архив внешней политики Российской Федерации (АВП РФ). - Ф. 162. - Оп. 59. П. $357 .-$ Д. 5.

2. АВП РФ. - Ф. 69. - Оп. 72. - П. 281. - Д. 13.

3. Ахтамзян А. А. Объединение Германии. Обстоятельства и последствия : очерки. - М. : МГИМО-Университет. 2008.

4. Ахтамзян А. А., Родович Ю. В. Внешняя политика Германской демократической республики. - М. : Наука, 1986.

5. Горбачев М. С. Жизнь и реформы : в 2 кн. - М. : Новости, 1995. - Кн. 2.

6. Горбачев М. С. Как это было: Объединение Германии. - М. : Вагриус, 1999.

7. История Германии : учеб. пособие : в 3 т. / под общ. ред. Б. Бонвеча, Ю. В. Галактионова. - М. : КДУ, 2008. - Т. 2 : От создания Германской империи до начала XXI века.

8. Колосов Г. В. Военно-политический курс Англии в Европе. - М. : Наука, 1984.

9. Максимычев И. Ф. Падение Берлинской стены : записки очевидца // Новая и новейшая история. - 2000. - № 4. - С. 128-135.

10. Максимычев И. Ф. Падение Берлинской стены : из записок советника-посланника посольства СССР в Берлине. - М. : Вече, 2011.

11. Михаил Горбачев и германский вопрос / Междунар. фонд социально-эконом. и политолог. исслед. «Горбачев-Фонд». - М. : Весь мир, 2006.

12. Терехов В. Как «закрывался» германский вопрос // Междунар. жизнь. - 1998. - № 8. C. 62-94.

13. Фалин В. М. Без скидок на обстоятельства. - М. : Республика : Современник, 1999.

14. Boelsche J. «Das ist ja unfassbar!» // Der Spiegel. - 1999. - № 45. - S. 86-103.

15. Britain in the 80s. The Spectators view of the Thatcher decade. - London : Grattonbooks, 1989.

16. Britischer Staatsminister im Aussenministerium empfangen // Neues Deutschland. - 1980. November, 4. - S. 2.

17. Deeds $W$. The rise of the fourth Reich is far from nigh // Daily Telegraph. - 1989. - November, 13. - P. 16.

18. Dokumente zur Deutschlandpolitik. Deutsche Einheit (Sonderedition aus den Akten des Bundeskanzleramtes 1989/90). - München : R. Oldenbourg Verlag, 1998. 
19. Foreign and Commonwealth Office. Diplomatic report No. 27/81. German Democratic Republic: Annual review for 1980 [Electronic resource] / Archive (FCO) - URL : www.margaret thatcher.org/document/7009D8445F24493EB8B876BF52FC5610.pdf (date of access : 15.11.2010). 20. Foreign and Commonwealth Office. Diplomatic report No. 23/82. German Democratic Republic : Annual review for $1981 / /$ Margaretthatcher.org [Electronic resource] - URL : www.margaret thatcher.org/document/5C13ED99B2EE4FCFA104134EE5DC7B19.pdf (date of access : 15.11.2010).

21. Foreign and Commonwealth Office. Diplomatic report No. 25/83. German Democratic Republic : Annual review for 1982 // Margaretthatcher.org [Electronic resource] - URL : www.margaret thatcher.org/document/99B4677961234019B58DFBABD1039E49.pdf (date of access : 15.11.2010).

22. Foreign and Commonwealth Office. Diplomatic report No. 4/84. German Democratic Republic : Annual review for 1983 // Margaretthatcher.org [Electronic resource] - URL : www.margaret thatcher.org/document/99B4677961234019B58DFBABD1039E49.pdf (date of access : 15.11.2010).

23. Foreign and Commonwealth Office. Despatch. Selective distribution. German Democratic Republic : Annual review for 1985 // Margaretthatcher.org [Electronic resource] - URL : www.margaretthatcher.org/document/6CB5413D871C4C30A4DA46F57B257F5C.pdf (date of access : 15.11.2010).

24. Foreign and Commonwealth Office. Despatch. Selective distribution. German Democratic Republic : Annual review for 1986 // Margaretthatcher.org [Electronic resource] - URL : www.margaretthatcher.org/document/141AC9B18A4A439FB20F845C0A5AB94E.pdf. (date of access : 15.11.2010).

25. Foreign and Commonwealth Office. Despatch. Selective distribution. German Democratic Republic : Annual review for 1988 // Margaretthatcher.org [Electronic resource] - URL : www.margaretthatcher.org/document/14DFD198281A43D2A2ABBAFB185B8266.pdf (date of access : 15.11.2010).

26. Foreign and Commonwealth Office. Despatch. Selective distribution. German Democratic Republic : Annual review for 1989 // Margaretthatcher.org [Electronic resource] - URL : www.margaretthatcher.org/document/BB7F33C83642424F9A83543C4B1CCFA7.pdf (date of access : 15.11.2010).

27. Garton Ash T. Germany again? // The Spectator. - 1989. - September, 16. - P. 11-12.

28. Garton Ash T. The new Berlin Wall // The Spectator. - 1980. - October, 25 - P. 10.

29. Garton Ash T. Yesterday's man // The Spectator. - 1989. - October, 28. - P. 12-13.

30. Gatermann R. Thatcher sorgt sich um Gorbatschow // Die Welt. - 1989. - November, 15. - S. 6.

31. Geissmar C. Frau Thatcher: Jetzt muss die Mauer fallen // Die Welt. - 1989. - November, 11/12. - S. 5.

32. Genscher H.-D. Erinnerungen. - Berlin : Siedler, 1995. - $1008 \mathrm{s.}$

33. Geschichte der Deutschen. 1949-1990 / ed. E. Fuhr. - Frankfurt-am-Mein : Insel, 1990.

34. Harvey $R$. A new world order in the making // Daily Telegraph. - 1989. - November, 14. P. 20.

35. Himmler N. Zwischen Macht und Mittelmass: Grossbritanniens Aussenpolitik und das Ende des kalten Krieges. - Berlin : Duncker\&Humblot, 2001.

36. How they see the fall of the Wall // Daily Telegraph. - 1989. - November, 11. - P. 15.

37. Johnson B. Bonn denies it is seeking one Germany // Daily Telegraph. - 1989. - November, 14. - P. 15.

38. Judt M. DDR-Geschichte in Dokumenten. - Bonn : BZPB, 1998.

39. Kauders M. Volkskammerabordnung setzte die Gaespraeche in London fort // Neues Deutschland. - 1982. - Dezember, 9. - S. 1-2. 
40. Knopp G., Kuhn E. Die deutsche Einheit: Traum und Wirklichkeit. - Frankfurt-am-Mein : Ullstein, 1991.

41. Krenz E. Gefaengnis-Notitzen. - Berlin : Das neue Berlin, 2009.

42. Marston E. A frost in Berlin // The Spectator. - 1979. - May, 5. - P. 8-10.

43. Murray I. Kohl reunification plan gives Krenz a breathing space // The Times. - 1989. - November, 30. - P. 8.

44. Murray I. Kohl says «We belong together»// The Times. - 1989. - November, 11. - P. 1.

45. Owen R. Thatcher urges EC to develop East bloc links as top priority // The Times. - 1989. November, 14. - P. 1.

46. Parker W. Geopolitical theorist has renewed relevance // Daily Telegraph. - 1989. - November, 11. - P. 14.

47. Parliamentary debates. House of commons. V. 77. - London : HMSO, 1985.

48. Parliamentary debates. House of commons. V. 123. - London : HMSO, 1988.

49. Parliamentary debates. House of commons. V. 130. - London : HMSO, 1988.

50. Parties join Thatcher in welcoming change // The Guardian. - 1989. - November, 11. - P. 4.

51. Poetzsch H. Deutsche Geschichte von 1945 bis zur Gegenwart. - Muenchen : Olzog, 2006.

52. Russia agrees to Germany inside Nato // The Times. - 1990. - July, 17. - P. 1.

53. Thatcher M. Speech to NATO Summit (4 Dec 1989) // Margaretthatcher.org [Electronic resource] - URL : www.margaretthatcher.org/speeches/displaydocument.asp?docid=110773 (date of access : 8. 11.2007).

54. Weltweit starkes Echo auf die Gespräche Erich Honeckers // Neues Deutschland. - 1987. - September, 9. - S. 6.

55. Wir sind alle Berliner : Editorial // New statesman. - 1989. - November, 17. - P. 4.

56. Witness seminar. Berlin in the Cold War, 1948 - 1990. German Unification, 1989 - 1990. London : Lancaster House, 2009. - 121 p.

57. Wolfrum E. Die Mauer. Geschichte einer Teilung. - Muenchen : Olzog, 2009.

58. Woollacott M. Germans seize their moment of national opportunity // The Guardian. - 1989. November, 11. - P. 1.

59. Zur Politik der friedlichen Koexistenz gibt es keine vernuenftige Alternative // Neues Deutschland. - 1985. - April, 10. - S. 1.

\section{ГДР во внешней политике Великобритании в 1979-1989 г2. (Ирина Ковяко)}

Анализируется политика Великобритании в отношении ГДР в 1979-1989 гг. Восточногерманский вектор британской внешней политики в указанный период был неотделим от проблемы германского урегулирования. После раскола немецкого государства Великобритания являлась одной из четырех держав, ответственных за судьбу послевоенной Германии. На основе широкого круга источников автор исследует основные направления взаимоотношений Великобритании с Восточной Германией в период правления кабинета М. Тэтчер. В статье определены основные формы сотрудничества двух стран, а также установлен комплекс факторов, которые препятствовали развитию политического диалога. Особое место в статье отведено выявлению особенностей политики Великобритании по германскому вопро- 
су во время нарастания общественно-политического кризиса в ГДР и падения Берлинской стены. Отдельное внимание уделено анализу позиций премьер-министра, Форин офис и политических партий Великобритании.

\section{Ключевые слова}

Германский вопрос; ФРГ; ГДР; перестройка; НАТО; ОВД; Восточный Берлин; СЕПГ; геополитические интересы Великобритании.

\section{The German Democratic Republic in the foreign policy of Great Britain (1979-1989) (Iryna Kaviaka)}

This article is devoted to the research of British policy in regard to GDR in 1979 - 1989. The East German vector of the British foreign policy in the indicated period was inseparable from the problem of the German settlement. After the division of the German state Great Britain was one of the Four Powers responsible for the post-war Germany. Taking into account the norms of international law the solution of the German question was impossible without direct participation of Great Britain. On the basis of wide circle of sources the author investigates basic directions of the Great Britain relations with East Germany in the period of $\mathrm{M}$. Thatcher government. The basic cooperation forms between two countries are stated in the article. The complex of factors that prevented from further development of political dialogue is set. The revealing of special features of British politicy on the German question during the growth of social and political crisis in GDR and falling of the Berlin wall takes a special place in the article. Separate attention is paid to the analysis of the Prime Minister's, Foreign Office and British political parties positions.

\section{Key words}

The German question; the FRG; the GDR; the restructuring; NATO; MIA; East Berlin; the SED; the geopolitical interests of the United Kingdom.

Статья поступила в сентябре 2015 г.

\footnotetext{
Рецензенты:

Субботин О. Г. - кандидат исторических наук, доцент кафедры всеобщей истории и методики преподавания истории БГП;

Шарапо А. В. - доктор исторических наук, профессор кафедры международных отношений факультета международных отношений Белорусского государственного университета.
} 


\section{ВНЕШНЕПОЛИТИЧЕСКАЯ МЫСЛЬ РОССИИ \\ О ТРАНСФОРМАЦИИ СОВРЕМЕННОЙ СИСТЕМЫ \\ МЕЖДУНАРОДНЫХ ОТНОШЕНИЙ}

\section{А. П. Косов}

кандидат исторических наук,

доиент кафедры всеобщей истории и мировой культуры

Витебского государственного университета имени П. М. Мамерова

УДК $327(470+571)$

Сегодня мы являемся свидетелями мощных трансформационных процессов, постепенно изменяющих конфигурацию современной системы международных отношений, сложившейся после окончания холодной войны. Данные изменения служат предметом жарких дебатов среди представителей политико-академического сообщества, общественности и СМИ.

Неудивительно, что в мировой историографии насчитывается множество работ, интерпретирующих происходящие события. В частности, можно назвать известные публикации Зб. Бжезинского, Ф. Закария, Н. В. Злобина, Г. Киссинджера, Дж. Фридмана, П. Ханна [6; $25 ; 26 ; 35 ; 66 ; 67]$.

Большое внимание вопросам развития современного миропорядка уделяют и российские авторы. В российской историографии выделяется обширный корпус литературы, посвященной ключевым вопросам функционирования постбиполярной системы международных отношений. Так, одни авторы (Ф. Д. Бобков, А. Г. Дугин, Н. А. Косолапов, Г. И. Мирский, С. М. Рогов) исследовали влияние распада СССР на трансформацию существовавшей несколько десятилетий послевоенной системы международных отношений $[7 ; 24 ; 41$; 48; 58]. Другие (В. Г. Барановский, Е. Ю. Гуськова, Г. А. Дробот, М. В. Ильин, Г. В. Корнилов, В. А. Кременюк, П. А. Цыганков) - влияние на мировую политику различных кризисов $[4 ; 17 ; 23 ; 28 ; 38 ; 43$; 68]. Третьи (С. В. Кортунов, В. М. Кулагин, А. И. Уткин) - влияние фактора международного терроризма на изменения в современной системе международных отношений [40; 44; 63]. Четвертые (Е. П. Бажанов, А. Д. Богатуров, К. Н. Брутенц, А. А. Громыко, В. Л. Иноземцев, С. А. Караганов, В. А. Кременюк, А. И. Уткин) - попытки США 
создать однополярный мир и реакцию мирового сообщества, и в первую очередь России $[3 ; 8 ; 10 ; 16 ; 29 ; 30 ; 42 ; 62]$.

В представленной статье предпринята попытка рассмотреть российские оценки трансформационных процессов в современной системе международных отношений. Поставленная цель представляется вполне актуальной и обоснованной, поскольку российская школа международных исследований, наряду с американской и французской, признается одной из ведущих в мире. К тому же российская историография ежегодно пополняется значительным количеством работ о современных международных отношениях, требующих осмысления и систематизации.

Безусловно, рассмотреть весь спектр оценок в российском внешнеполитическом дискурсе невозможно из-за огромного числа исследований. Поэтому в статье представлены лишь некоторые суждения представителей политико-академического сообщества России относительно современной системы международных отношений.

Как показывают многочисленные исследования, современная система международных отношений в отличие от своих предшественниц не имеет общепринятого названия. Более того, многие исследователи считают ее модифицированным вариантом ялтинско-потсдамской системы, сложившейся по итогам Второй мировой войны. В какой-то мере это действительно так. Ведь ее ключевые механизмы продолжили свое функционирование и в новых постбиполярных условиях: ООН; ГАТТ/ВТО; МВФ; принцип нерушимости и неизменности границ в мире (за исключением ряда спорных территорий и территориальных конфликтов); ряд международных договоров, заключенных в годы холодной войны и т. д.

Некоторые исследователи считают, что сохранение принципов ялтинско-потсдамской системы международных отношений после распада Советского Союза было обусловлено фактом стратегического паритета России и США в качестве силовой составляющей международных отношений [65, с. 27]. Но все же сама ялтинско-потсдамская система международных отношений прекратила свое существование в начале 1990-х гг. в связи с распадом СССР - одного из ведущих структурообразующих элементов. Более того, шаг за шагом ее наследие стало подвергаться серьезным трансформационным изменениям. В итоге вызовы современного мира поставили множество сложных и актуальных вопросов перед экспертным сообществом. 
При анализе современной системы международных отношений основное внимание представителями политико-академического сообщества России уделялось и уделяется изменению соотношения сил между основными геополитическими центрами - США, Европой, Российской Федерацией, КНР и другими «поднимающимися» странами, а также роли и месту региональных и международных организаций, институтов и объединений в мировой политике.

Рассматривая трансформацию международной системы в конце XX - начале XXI в., эксперты обращают внимание в первую очередь на ключевые события, с которыми многие связывают существенные изменения системы, влияющие на ее структуру и сущность. Среди таких эпизодов мировой политики можно выделить следующие: распад СССР, войну в Югославии, теракты 11 сентября 2001 г. и вторжения Запада в Афганистан и Ирак, кавказский кризис 2008 г., глобальный финансово-экономический кризис, события на Ближнем Востоке, украинский кризис.

Отталкиваясь от ключевых точек мировой политики, отдельные российские ученые выделяют в истории эволюции современной системы международных отношений три этапа:

1) 1991-2001 гг. - попытки Запада во главе с США создать новый миропорядок;

2) 2001-2008 гг. - активизация политики Соединенных Штатов по укреплению своего влияния в мире на основе идеи глобальной борьбы с международным терроризмом;

3) 2009-2015 гг. - попытки ревизии современного миропорядка $[65$, c. 5$]$.

Переформатирование механизмов функционирования ЯлтинскоПотсдамской системы международных отношений стало возможным в результате распада СССР, когда на политической карте мира осталась лишь одна сверхдержава - США. В связи с этим интересны оценки внешнеполитической составляющей этого процесса. В российской внешнеполитической мысли можно встретить разные интерпретации влияния внешнего фактора на процесс дезинтеграции СССР. Например, точки зрения о ведущей роли Запада (особенно США) в развале советской державы в первую очередь характерны для так называемых российских национал-патриотов. Так, практически сразу же после исчезновения с политической карты мира советского государства они заговорили о происках Америки, в результате чего и 
произошел крах СССР. На страницах ряда изданий («Молодая гвардия», «Литературная Россия», «День», «Наш современник», «Русский вестник» и др.) активно популяризировалось утверждение о существовании «тайного заговора» Соединенных Штатов против Советского Союза в целях установления нового мирового порядка.

Мнения о том, что «СССР убили» профессионально действующие политики администраций Р. Рейгана и Дж. Буша-ст., придерживался и известный российский политолог Г. О. Павловский [50, c. 2]. В публицистической и научно-популярной литературе широко культивировалась версия о том, что ЦРУ с опорой на советских политиков (так называемых «агентов влияния») сумело развалить Советский Союз. В России достаточно много написано о роли руководства и интеллектуалов СССР в сдаче советских позиций в мире и развале страны. Например, историк А. В. Островский утверждает, что, провозглашая идею создания «социализма с человеческим лицом», генсек М. С. Горбачев и его окружение с самого начала ставили задачу разрушения СССР, чему и посвятил свою книгу [49]. О подготовке «агентов влияния» писали в своих работах и другие российские авторы - Ф. Д. Бобков, И. Н. Панарин, О. А. Платонов, В. Широнин и др. [7; 51, с. $173 ; 52$, с. 164-165; 69].

Однако многие российские авторы не считают, что давление извне сыграло главную роль в подрыве и развале советской державы. Признавая неблагоприятный исход холодной войны для России как правопреемницы СССР, они справедливо, на наш взгляд, утверждают о том, что Соединенные Штаты лишь удачно воспользовались представившимся им историческим шансом, связанным с коллапсом Советского Союза. По мнению ряда экспертов (Е. П. Бажанов, С. В. Кортунов, Н. А. Косолапов, Г. И. Мирский и др.), СССР распался в результате внутренних трудностей страны, а не происков Запада [2; 39, с. 136-169; 41; 48, с. 2]. В результате западный истеблишмент, почувствовав «пьянящее головокружение» от победы над коммунизмом, решил, что теперь весь мир будет жить по его правилам. А Вашингтон сможет стать одновременно и судьей, и шерифом мирового сообщества.

Российские национал-патриоты обращали внимание на тот факт, что политика Запада подразумевала развал России и включение ее частей в зоны влияния развитых стран в качестве сырьевого придатка и рынка сбыта. Так, лидер неоевразийства А. Г. Дугин писал, что За- 
пад (в первую очередь США) стремился превратить Россию в слабую региональную державу, неспособную играть значительную роль в мировой политике [24, с. 193-213].

Действительно, по общепризнанному мнению, характер современной системы международных отношений в существенной степени определяется ролью и местом на мировой арене США. По словам известного международника К. Н. Брутенца, распад Советского Союза открыл для Вашингтона уникальную возможность стать единственной империей мира, что оказало дезорганизующее влияние на международную систему, снизило авторитет международных институтов и резко усилило конфликтный потенциал. Американцы продолжили следовать логике силы. Сложившаяся после распада СССР ситуация в мире позволяла Вашингтону игнорировать международное право и мнения других государств, используя в качестве своего аргумента превосходящую военную силу [11, с. 20-21]. Тем более что Россия в 1990-е гг. утратила роль самостоятельного игрока на мировой арене $[11$, с. 30]. Не было в мире еще и других центров силы. В то время Китай только начинал свой подъем, а Европа так и не смогла избавиться от американской опеки. В результате, по мнению директора Института США и Канады РАН С. М. Рогова, на рубеже XX-XXI вв. Америка оказалась на вершине своего могущества. Не имея равного по силам геополитического противника, способного сдержать американскую мощь, американское руководство поставило своей целью закрепление роли США в ранге единственной сверхдержавы в однополярном мире. Данная стратегия была принята на вооружение администрациями Дж. Буша-ст., Б. Клинтона, а затем и Дж. Буша-мл. [57]. Поэтому, согласно С. А. Караганову, 1990-е гг. стали иллюзией однополярного мира [32, с. 9].

Правда, как показывают многие публикации, в начале 1990-х гг. либеральная часть российского политико-академического сообщества всерьез рассчитывала на сохранение ялтинско-потсдамских договоренностей в новых реалиях путем тесного и конструктивного сотрудничества России и США в многополярном мире. Эксперты высказывали оптимистические оценки по поводу коренного изменения международной политики в сфере безопасности, сокращения ядерных арсеналов и т. д. Подтверждение этому можно найти в работах А. В. Козырева, И. Е. Малашенко, С. М. Рогова и др., датируемых первой половиной 1990-х гг. [36; 46; 58; 56]. 
Однако в дальнейшем несбывшиеся ожидания сильно умерили их оптимизм. Более того, реальная действительность заставила многих экспертов представлять мир иначе - как попытку США «перекроить» мир под себя. Как отмечал известный политолог А. К. Пушков, в начале 1990-х гг. симпатизировавший Западу, пренебрежение Москвы геополитикой привело к краху прозападного курса А. В. Козырева, который «означал подыгрывание стремлению США максимально укрепить свое геополитическое положение за счет слабеющего влияния Москвы» [54, с. 5]. Чуть позже даже сам министр А. В. Козырев, обосновывая поворот во внешнеполитическом курсе России в середине 1990-х гг., назвал иллюзиями устремления тех западных политиков, которые считали, что с Россией можно построить не равноправное, а подчиненное партнерство [36; 74]. Правда, американцы оказались подвержены самонадеянности силы, поскольку после распада СССР роль силового фактора в мировой политике не уменьшилась, а лишь возросла.

В качестве наиболее характерного примера можно назвать действия Запада во главе с США на Балканах. В первое время после начала кризиса на территории бывшей Югославии в России появилось немало благожелательных оценок поведения западных стран. В частности, таких позиций придерживались П. Е. Кандель, А. А. Язькова, В. М. Каменецкий и др. [31; 70, с. 4; 71, с. 12]. Их оценки мировой ситуации полностью отвечали внешнеполитической линии МИД РФ, ориентированной на сотрудничество с Западом.

С другой стороны, уже в первой половине 1990-х гг. имелись и критические оценки подходов Запада к урегулированию югославского конфликта. В частности, были подвергнуты критике введенные санкции против СРЮ, к которым присоединилась и Российская Федерация, и обращено внимание на политику США, России и европейских государств на Балканах $[12$, с. 7 ; 13, с. 1,$3 ; 18$, с. 3; 21, с. 14; 60]. Как отмечали в сентябре 1992 г. на страницах «Правды» академик РАН П. В. Волобуев и ведущий научный сотрудник ИМЭПИ РАН Л. В. Тягуненко, «непокорная Югославия не вписывается в новый мировой порядок», созданный под эгидой Запада во главе с США [14, c. 3].

Критика поведения Запада на Балканах в российской историографии еще более усилилась во второй половине 1990-х гг. Дело в том, что с 1995 г. заметно активизировались трансформационные 
процессы во внешней политике России, направленные на отход от прозападной ориентации. Российская внешнеполитическая мысль осознала истинную политику Запада, направленную на ущемление и унижение их страны в мировой политике [3]. Поэтому все большее число экспертов (Н. И. Арбатова, П. В. Волобуев, Л. В. Тягуненко, Е. Ю. Гуськова, Г. В. Корнилов и др.) стало рассматривать действия США и ряда западноевропейских стран на Балканах как первую попытку переформатировать существующий порядок в Европе [1; 15; $38 ; 73]$.

Еще больше о попытках Запада установить свои правила в мировой политике российские эксперты заговорили в конце 1990-х гг. после обострения ситуации в Косово. Агрессивная политика Североатлантического альянса в косовском конфликте весной 1999 г. вызвала шквал критики в сторону США и НАТО в российских публикациях $[4 ; 17 ; 19 ; 20 ; 28 ; 43 ; 72]$. Их анализ показывает, что российские эксперты озаботились складывающейся ситуацией не просто в связи с локальным конфликтом на территории Европы, а в связи с попыткой Запада установить новый мировой порядок по своим правилам. По мнению Г. М. Сергеева, агрессивным нападением на Югославию в 1999 г. НАТО разрушила мировой порядок, основанный на международном праве [59, с. 604].

Таким образом, некоторые российские эксперты (А. Д. Богатуров, Ю. П. Давыдов и другие) разграничили «старый» и «новый» мировой порядок именно событиями конца 1990-х гг. в бывшей Югославии, считая, что международные отношения находятся на поворотном отрезке истории [9, с. 43-44; 22, с. 12].

Следующим важным событием трансформации наследия ялтинско-потсдамского миропорядка в категориях силы против нормы права стала террористическая атака против США.

Рассматривая вызовы и угрозы современности, известный политолог В. М. Кулагин отмечает, что в начале XXI в. началось масштабное вторжение в пространство военно-политической безопасности новых негосударственных действующих лиц, а также изменение роли национальных государств. Поэтому, как считает эксперт, речь идет не только о «международной безопасности» в ее межгосударственной ипостаси, а о явлении с более широким набором действующих лиц, которое по этой причине более корректно было бы именовать «мировой безопасностью» [44, с. 41]. 
После драмы 11 сентября 2001 г. и ответной реакции Соединенных Штатов многие российские исследователи (К. Н. Брутенц, Анат. А. Громыко, А. А. Кокошин, В. А. Кременюк, С. М. Рогов и др.) еще больше заговорили об американском гегемонизме в мире, когда Вашингтон окончательно попытался отбросить все нормы международного права и устоявшиеся международные принципы и силой навязать свое мировидение другим странам и народам $[11$, с. $97 ; 16$, с. 86 ; $37 ; 40 ; 42$, с. 3,14$]$.

Следует отметить, что в российской историографии даже появилось мнение о том, что 11 сентября 2001 г. стало началом «новой эры» в истории человечества и новой фазы в развитии международных отношений [26, с. 15]. Правда, некоторые исследователи с этим в корне не согласны [59, с. 592]. Так, известные американисты Э. Я. Баталов и В. А. Кременюк сочли отсчет нового периода мировой истории от террористической атаки на США явным преувеличением, имеющим не только психологическую, но и политическую подоплеку. По их мнению, новый мир стал складываться не 11 сентября 2001 г., а десятью годами ранее, когда рухнули не только мировая социалистическая система и Советский Союз, но и весь послевоенный ялтинско-потсдамский миропорядок. А события начала XXI в. лишь положили начало формированию в мире новой политической ситуации $[5$, с. 19$]$.

Такой точки зрения придерживался и известный международник Анат. А. Громыко, который указывал на то, что становление нового мирового порядка берет свой отсчет с 11 сентября 1990 г., когда об этом заявил Дж. Буш-ст. на объединенной сессии конгресса США [16, c. 78]. А 11 сентября 2001 г. - это просто своеобразный катализатор, использованный Вашингтоном для изменения мирового порядка и перехода в состояние «Pax Americana» [16, с. 86]. Анат. А. Громыко отметил, что Дж. Буш-мл. использовал борьбу с терроризмом как средство защиты американских интересов по всему миру. По его словам, если им это выгодно, США легко расстаются с принципом «совместных действий», чем, бесспорно, подрывают институты международных отношений [16, с. 79]. По мнению завотделом внешнеполитических исследований Института США и Канады РАН П. Т. Подлесного, борьба с международным терроризмом - это новый организующий принцип внешней политики, который выполняет функции антикоммунизма периода холодной войны, а сложившуюся ситуацию аме- 
риканские политики максимально используют для укрепления своих позиций в мире [53, с. 3]. Солидарен с коллегами и К. Н. Брутенц, который указал на то, что 11 сентября не стало для мира эпохальной точкой, изменившей траекторию мирового развития, природу международных отношений или расстановку сил в мировой политике [11, c. 113].

Согласно американисту А. И. Уткину, «Вашингтон исходит из того, что поставленная на грань выживания, извлекшая опыт из трагедий, подобных сентябрьской атаке, международная система неизбежно вручит бразды правления наиболее мощной и организованной международной силе - Америке». Таким образом, опираясь на собственную мощь, США рассчитывали навести должный порядок на планете [64, с. 58]. В качестве базовых элементов глобального лидерства США исследователь в своей работе «Американская стратегия для XXI века» назвал следующие: мировая гегемония, опора на региональных союзников и баланс сил, соответствующий интересам США и позволяющий им контролировать «потенциальных врагов» [62].

В результате, как отмечает С. А. Караганов, в 2000-е гг. международное право, даже в том несовершенном виде, в котором оно было создано после Второй мировой войны, оказалось опрокинутым, и верх в мире берет «закон джунглей». По словам исследователя, рассыпаются на глазах и остатки международной договорной системы, ограничивавшей гонку вооружений, а сама гонка вооружений набирает в мире обороты. Действия Вашингтона привели к возвращению военной силы на свое традиционное место в системе международных отношений. В большинстве своем международные организации оказались дискредитированы либо значительно ослаблены. В результате чего сама система международной безопасности становится все более хрупкой [34, с. 8].

Очевидность использования Вашингтоном силы в целях обеспечения своих интересов отмечалась многими российскими экспертами - А. Д. Богатуровым, В. М. Кулагиным, С. М. Роговым [8; 44; 57]. Однако проявление американцами силы вовсе не означает всесилия США. Как показали события в Афганистане и Ираке, Соединенные Штаты, несмотря на свою политическую, военную и экономическую мощь, столкнулись с серьезными трудностями и были вынуждены обратиться к другим странам и международным институтам за помощью. Эта мысль четко отражена во многих российских публикациях 
последних 10-15 лет. Так, В. Л. Иноземцев и С. А. Караганов заявили о том, что создается впечатление неспособности США более играть роль сверхдержавы. По их словам, Америка серьезно подорвала свою мощь вторжением в Ирак. В результате неразумного применения военной силы США вместо продвижения к однополярному миру поставили под вопрос свое влияние, сделав огромный шаг в сторону мира «бесполярного» - хаотичного и неуправляемого [29, с. $21 ; 30$, с. 70$]$. К общему перенапряжению и иракскому фиаско Соединенные Штаты привело «высокомерие силы» [33].

О том, что попытка установить американский мировой порядок потерпела крушение, говорил еще в 2002 г. и Ф. И. Лодыгин [59, с. 613]. Американист А. К. Пушков также подчеркнул, что «у Америки не получилось воспользоваться возможностью установить свою тотальную гегемонию», которая была у Вашингтона в 1990-е - начале 2000-х гг. [55, с. 54]. А известный международник К. Н. Брутенц пришел к бесспорному выводу о закате американской гегемонии в мире. По его словам, она сталкивается с препятствиями, а нередко с прямым сопротивлением других субъектов международных отношений $[11$, c. 225,229$]$.

Таким образом, США показали, что не обладают такой концентрацией ресурсов и политической воли, чтобы установить «Рax Americana» в XXI в. В результате наступило время подъема незападных держав и упадка Запада. Наступил мир, который многие называют многополярным. Однако, по мнению С. А. Караганова, многополярность тоже временное явление и отражает неприятие мира однополярного (термин появился именно как его отрицание), а также пока неспособность или нежелание увидеть макротенденции, которые уже работают [32, с. 9].

Некоторые российские политологи не спешат связывать с многополярностью решение всех проблем мирового развития. Как справедливо отмечает В. М. Кулагин, в мировой историографии насчитывается много работ, критикующих однополюсность мира, но подробных исследований альтернативной системы мирового взаимодействия явно недостаточно. Эксперт отмечает, что сложившейся ситуации многими противопоставляется система, при которой важнейшие решения по проблемам безопасности должны приниматься на многосторонней основе. Но такой коллективный подход неизбежно требует коллективизма при реализации принятых таким образом решений, 
более равномерного распределения бремени и рисков. Однако одни державы не имеют материальных возможностей для «замещения» США, другие - политической воли для взятия на себя доли общего бремени. Более того, по мнению В. М. Кулагина, обеспечение коллективизма в принятии решений и их реализации невозможно без реформирования $\mathrm{OOH}[44$, с. 50].

C. А. Караганов указывает, что многополярность в реалиях XXI в. - это систематизированный хаос, крайне опасный в современном мире с наличием и распространением ОМУ, терроризма, почти повсеместной политической активизацией масс и конфликтом цивилизаций [34, с. 8].

С точки зрения директора Института США и Канады РАН С. М. Рогова, мир после неудачи США в Ираке возвращается к многополярности, которая «может приобрести хаотичный характер, если не удастся создать новую систему коллективной международной безопасности». При этом, по словам ученого, продолжится усиление роли и влияния Китая и Индии. Прогнозируя мировую ситуацию в близлежащей перспективе, С. М. Рогов отмечал, что «утратив роль единственной сверхдержавы, США тем не менее останутся наиболее мощным государством в мировой экономике и политике. Однако в отличие от предыдущего периода Вашингтон будет стремиться обеспечивать свое лидерство, действуя не в одностороннем порядке, а в рамках многосторонних коалиций, выполнять роль балансира в многостороннем балансе сил» [57].

В первую очередь суждения о закате американской гегемонии в мире эксперты (К. Н. Брутенц, А. К. Пушков, А. А. Терентьев и др.) связывают с глобальным финансово-экономическим кризисом, который нанес существенный удар по имиджу Америки, заставив мир задуматься о возможности создания новой международной системы, где весомую роль играли бы другие игроки, например поднимающиеся страны Азии, и в первую очередь Китай, Индия и др. [10, с. 275462 ; 11 , с. $275-347 ; 55$, с. 52-57; 61, с. 114-146]. Действительно, финансово-экономический кризис со всей очевидностью показал расхождение между гегемонистскими амбицииями Вашингтона и интересами остального мирового сообщества [11, с. 224]. Поэтому ряд экспертов (К. Н. Брутенц, П. А. Цыганков) отмечают, что сегодня параллельно происходит рождение многополярности и отторжение «американского мира» $[10$, с. $97 ; 68$, с. 29]. Согласно прогнозам исследо- 
вателей из ИМЭМО РАН, в ближайшее десятилетие США утратят роль единственной сверхдержавы, но сохранят лидерство в экономической, военной и политической сферах среди других центров силы на мировой арене. Более того, как отмечают эксперты, по уровню ВВП на душу населения Соединенные Штаты увеличат отрыв от преследователей и по-прежнему будут играть ведущую роль в глобализационных процессах [47, с. 15, 230].

В контексте ослабления США на фоне финансово-экономического кризиса российские эксперты рассматривают и события августа 2008 г.

По мнению профессора МГУ Г. А. Дробот, принципиальных изменений в современном миропорядке они не произвели, но усилили позиции России, вставшей на тот же путь гуманитарных интервенций без согласия ООН, которым идут страны Запада [23, с. 8-9].

Анализируя сложную ситуацию в современном мире (конфликты на Ближнем Востоке, украинский кризис, иранская ядерная проблема и т. д.), российские эксперты (К. Н. Брутенц, С. А. Караганов, Г. И. Мирский, Е. Г. Пономарева, А. К. Пушков, С. М. Рогов, Т. А. Шаклеина и др.) отмечают дальнейший отход от принципов и механизмов, ранее стабилизировавших ялтинско-потсдамскую систему международных отношений.

Так, по мнению экс-министра иностранных дел РФ, а ныне президента РСМД И. С. Иванова, сегодня в мире наблюдается «ощущение стремительно надвигающихся фундаментальных перемен». Подобное отмечалось два с половиной десятилетия назад, когда уходил в историю биполярный мир, но тогда, согласно эксперту, остались неизменными прежние «несущие конструкции» мирового порядка ялтинско-потсдамской эпохи: основополагающие международные организации и институты (ООН, Всемирный банк, ОБСЕ, НАТО), ведущие принципы международного права, традиционные подходы великих держав к решению внешнеполитических проблем [27].

Однако эксперт констатирует, что «заморозить» систему международных отношений в середине второго десятилетия XXI в. еще на двадцать лет уже не получится. С точки зрения И. С. Иванова, об этом красноречиво свидетельствуют драматичные события в Украине, фактический слом системы региональной безопасности на Ближнем Востоке, а также рост национализма и обострение территориальных проблем в АТР [27]. 
Таким образом, анализируя ситуацию в современном мире, российские эксперты отмечают трансформацию современной системы международных отношений, проявляющуюся в постепенном сломе механизмов ялтинско-потсдамского миропорядка и отказе от его принципов. В российской внешнеполитической мысли насчитывается широкий спектр оценок и мнений относительно событий мировой политики на современном этапе. Однако большинство экспертов России разделяет точку зрения о том, что мир все дальше отходит от наследия ялтинско-потсдамской системы международных отношений, делая современный миропорядок непредсказуемым.

\section{Библиографические ссылки}

1. Арбатова Н. И. Мир или перемирие? // Мировая экономика и междунар. отношения. 1998. - № 9. - C. 78-85.

2. Бажанов Е. П. Америка: вчера и сегодня : в 2 т. - М. : Известия, 2005. - Т. 1.

3. Бажанов Е. П. Эволюция российской внешней политики в $90-\mathrm{e} г$ гг. // Дипломат. вестн. 1997. - № 2. - C. 59-67.

4. Барановский B. Косово. Российские интересы слишком значительны // Междунар. жизнь. -1999 . - № 6. - С. 34-46.

5. Баталов Э. Я., Кременюк В. А. Россия и США: соперники или соратники? Об опыте недавнего прошлого и возможных перспективах на будущее // США - Канада : экономика, политика, культура. - 2002. - № 6. - С. 19-36.

6. Бжезинский 3б. Стратегический взгляд : Америка и глобальный кризис. - М. : АСТ, 2013.

7. Бобков Ф. Д. Как готовили предателей : начальник полит. контрразведки свидетельствует...- М. : Эксмо : Алгоритм, 2011. -240 с.

8. Богатуров А. Д. Лидерство и децентрализация в международной системе // Междунар. процессы. - 2006. - № 3. - С. 5 - 15 .

9. Богатуров А. Д. Синдром поглощения в международной политике // Pro et Contra. 1999. - T. 4. № 4. - С. $28-48$.

10. Брутени К. Н. Великая геополитическая революция. - М. : Междунар. отношения, 2014.

11. Брутени К. Н. Закат американской гегемонии. - М. : Междунар. отношения, 2009.

12. Волков В. Югославия: искать не «врага», а решение // Моск. новости. - 1993. - 21 февр. C. 7 .

13. Волобуев П., Тягуненко Л. России не безразлично: принесет ли долгожданный мир на югославскую землю план Вэнса - Оуэна? // Правда. - 1993. - 27 февр. - С. 1, 3.

14. Волобуев П., Тягуненко Л. Старых друзей не бросают. Не ужесточать, а отменять санкции против Югославии // Правда. - 1992. - 16 сент. - С. 3.

15. Волобуев П. В., Тягуненко Л. В. Уроки дейтонских соглашений // Свобод. мысль. 1997. - № 2. - C. 84-91.

16. Громыко Анат. А. Становление нового мирового порядка // США - Канада : экономика, политика, культура. - 2002. - № 11. - С. 78-88. 
17. Гуськова Е. Ю. Кризис в Косове : история и современность // Новая и новейшая история. - 1999. - № 5. - С. 32-66.

18. Гуськова E. НАТО развязывает войну на Балканах // Красная звезда. - 1995. - 11 сент. C. 3.

19. Гуськова Е. Ю. Продолжающийся балканский кризис и политика России // Обозреватель. - 1999. - № 12. - С. 34-40.

20. Гуськова Е. Ю. Что мы предали, предав сербов : место России в сценарии НАТО // Российская Федерация сегодня. - 1999. - № 18. - С. 49-50.

21. Гуськова Е. Югославия: не надоело ли пожинать бурю? // Лит. газета. $-1992 .-8$ янв. C. 14 .

22. Давыдов Ю. П. Расширение зоны ответственности атлантического мира // США - Канада : экономика, политика, культура. - 2000. - № 3. - С. 12-30.

23. Дробот Г. А. Кавказский кризис 2008 г. в контексте концепции «плюралистической однополярности» // Вестн. Моск. ун-та. - Сер. 18. Социология и политология. - 2009. - № 1. C. 6-9.

24. Дугин А. Г. Основы геополитики : геополит. будущее России. - М. : Арктогея-центр, 1997.

25. Закария Ф. Постамериканский мир будущего. - М. : Европа, 2009.

26. Злобин Н. В. Второй новый миропорядок : геополит. головоломки. - М. : Эксмо, 2009.

27. Иванов И. В предчувствии перемен // Рос. газета [Электронный ресурс]. - 2015. - URL : http://www.rg.ru/2015/01/30/ivanov-statia.html (дата обращения : 12.04.2015).

28. Ильин М. В. Война в Югославии : от жертвоприношения Сербии к самоубийству Запада // Полис. - 1999. - № 2. - С. 110-113.

29. Иноземцев В. Л., Караганов С. А. О мировом порядке XXI века // Россия в глобальной политике. -2005 . - Т. 3. № 1. - С. 8-26.

30. Иноземцев $B$. Л. Россия в системе международных отношений XXI века // Междунар. жизнь. - 2002. - № 9/10. - С. 67-81.

31. Кандель П. Что нам Балканы? Ссора с Европой из-за Югославии как способ свалить правительство России // Новое время. - 1992. - № 25. - С. 32-33.

32. Караганов С. А. Венский конгресс XXI века // Рос. газета. - 2015. - 2 июня. - С. 9.

33. Караганов C. Новая холодная война // Россия в глобальной политике [Электронный реcypc]. - 2008. - URL : http://www.globalaffairs.ru/number/ n_11639 (дата обращения : 11.07.2015).

34. Караганов С. А. Холодный мир - поопасней «холодной войны» // Рос. газета. - 2007. 7 марта. - C. 8.

35. Киссинджер Г. Мировой порядок. - М. : АСТ, 2015. - 540 с.

36. Козырев А. В. Стратегия партнерства // Междунар. жизнь. - 1995. - № 5. - С. 5-15.

37. Кокошин A. A. О явлениях и тенденциях, определяющих облик мировой политики в первой декаде XXI века (тезисы) // Вестник аналитики [Электронный ресурс]. - 2003. - URL : http://www. isoa.ru/vestnik11.htm (дата обращения : 03.12.2006).

38. Корнилов Г. В. США и югославский кризис (1991 - 1997 гг.) // США: экономика, политика, идеология. - 1998. - № 4. - С. 67-77.

39. Кортунов С. В. Имперские амбиции и национальные интересы. Новое измерение внешней политики России. - М. : МОНФ, 1998.

40. Кортунов С. В. Становление нового мирового порядка // Междунар. жизнь. - 2002. № 6. - C. 77-94.

41. Косолапов Н. А. Новая Россия и стратегия Запада // Мировая экономика и междунар. отношения. - 1994. - № 1. - С. 5-18. 
42. Кременюк В. А. Две модели отношений США с окружающим миром: «заботливый отец» или «суровый шериф» // США - Канада: экономика, политика, культура. - 2004. - № 11. C. 3-14.

43. Кременюк В. А. Россия - США: первые уроки балканского кризиса 1999 г. // США - Канада: экономика, политика, культура. - 2000. - № 1. - С. 5-15.

44. Кулагин В. Глобальная или мировая безопасность? // Междунар. процессы. - 2007. № 2. - C. 38-51.

45. Кулагин В. М. Мир в XXI веке : многополюсный баланс сил или глобальный Рах Democratica? // Полис. - 2000. - № 1. - С. 22 - 37.

46. Малашенко И. Е. СССР и США после тоталитаризма и «холодной войны» // Междунар. жизнь. - 1991. - № 5. - С. 5-18.

47. Мировая экономика : прогноз до 2020 года / А. А. Дынкин [и др.]; под ред. акад. А. А. Дынкина. - М. : Магистр, 2007.

48. Мирский Г. И. Кто уничтожил СССР? // Независимая газета. - 1996. - 22 нояб. - С. 2.

49. Островский А. В. Глупость или измена? Расследование гибели СССР. - М. : Крымский мост-9Д, Форум, 2011.

50. Павловский Г. Как они уничтожили СССР // Независимая газета. - 1996. - 14 нояб. - С. 2.

51. Панарин И. Н. Первая мировая информационная война. Развал СССР. - М. : Питер, 2010.

52. Платонов О., Райзеггер Г. Конец Америки : истоки мирового кризиса. - М. : Алгоритм, 2009.

53. Подлесный П. Т. Внешняя политика США : новая реальность // Независимая газета. 2001. - 5 окт. - С. 3.

54. Пушков A. Внешняя политика России // Независимая газета. - 1995. - 16 нояб. - С. 1, 5.

55. Пушков А. К. Гроссмейстеры Зазеркалья. - М. : Эксмо, Алгоритм, 2009.

56. Рогов С. М., Суриков A. В. Перспективы радикальных сокращений стратегических наступательных вооружений России и США // США - экономика, политика, идеология. - 1992. № 5. - C. 3-12.

57. Рогов С. М. После войны в Ираке : крах однополярного мира // Независимая газета. HBO [Электронный ресурс]. - 2006. - URL : http://nvo.ng.ru/concepts/2006-12-08/1_iraq.html (дата обращения : 25.08.2015).

58. Рогов С. М. Россия и США в многополюсном мире // США - экономика, политика, идеология. -1992 . - № 10. - С. 3-14.

59. Россия в новом веке: внешнеполитическое измерение : сб. материалов заседаний Экспертного совета Комитета Совета Федерации по междунар. делам, 2002 г.; под ред. А. А. Коробейникова // Офиц. портал Совета Федерации Федерального собрания РФ [Электронный pecypc]. - URL : http://www.council.gov.ru/ media/files/41d44f2433c246d41ab7.pdf (дата обращения : 26.04.2015).

60. Самуйлов С. М. США, НАТО, Россия и боснийский кризис // США: экономика, политика, идеология. - 1995. - № 7. - С. 16-30.

61. Терентьев A. А. Эпоха Обамы: наши интересы в Белом доме. - М. : Алгоритм, 2012.

62. Уткин А. И. Американская стратегия для XXI века. - М. : Логос, 2000.

63. Уткин А. И. Новый мировой порядок. - М. : Алгоритм, Эксмо, 2006.

64. Уткин А. И. Под сенью новой империи // Россия в глобальной политике. -2002 . - № $1 .-$ C. 50-61.

65. Фененко А. В. Современная история международных отношений. 1991-2015 : учеб. пособие. - М. : Аспект Пресс, 2015.

66. Фридман Дж. Следующие 100 лет : прогноз событий XXI века. - М. : Эксмо, 2010.

67. Ханна П. Как управлять миром. - М. : Астрель, 2012. 
68. Цыганков П. А. После кавказского кризиса : мировой порядок и внешняя политика России // Вестн. Моск. ун-та. - Сер. 18. Социология и политология. - 2009. - № 1. - С. 29-34.

69. Широнин В. Агенты перестройки : рассекреченное досье КГБ. - М. : Эксмо, Алгоритм, 2010.

70. Язькова А. Балканский кризис : подвластно ли будущее историческому прошлому? // Независимая газета. - 1992. - 14 окт. - С. 4.

71. Язькова А., Каменеикий В. Санкции были правомерны // Моск. новости. - 1992. - 12 июля. - С. 12.

72. Guskova J. Kosovo as one of the stages in the NATO and U.S. strategy // Review of International Affairs. - Belgrade. - 1999. - № 1085/1086. - P. 8-13.

73. Guskova J. The Balkan crisis - the Serbs and Islam in the big power designs // Eurobalkans. Athens. - 1996/1997. - Winter. - № 25. - P. 17-20.

74. Kozyrev A. V. Partnership or Cold Peace? // Foreign Policy. - 1995. - Summer. - P. 3-14.

\section{Внешнеполитическая мысль России о трансформации современ- ной системы международных отношений (Александр Косов)}

Исследование актуальных проблем международных отношений и глобального развития в мировой внешнеполитической мысли - актуальная и значимая задача. Оно помогает проследить связь теории международных отношений с реальной политикой.

В статье показаны популярные в российском научно-политическом сообществе точки зрения относительно развития современной системы международных отношений, рассмотрены взгляды отдельных экспертов и политиков на ряд актуальных вопросов, касающихся распада СССР, ситуации на Балканах, международного терроризма, кавказского кризиса 2008 г., глобального финансово-экономического кризиса, ситуации на Ближнем Востоке, украинского кризиса.

\section{Ключевые слова}

Внешнеполитическая мысль; исследователи; кризисы; международный терроризм; многополярность; однополярность; Россия; система международных отношений; США.

\section{Russian foreign policy thinking about the transformation of the contem- porary system of international relations (Alexander Kosov)}

Study of the actual problems of international relations and global development is very actual and important task in the world foreign policy 
thinking. It helps to trace the connection between the theory of international relations with a real policy.

Purpose of the article - to show some of the most popular views on the development of the contemporary system of international relations in the Russian scientific and political fellowship. The author examines the views of some experts and politicians on a number of actual issues relating to the collapse of the Soviet Union, the situation in the Balkans, international terrorism, the Caucasian crisis 2008, the global financial and economic crisis, the situation in the Middle East, the Ukrainian crisis.

\section{Key words}

Foreign policy thinking; researchers; crises; international terrorism; multipolarity; unipolarity; Russia; the system of international relations; the USA.

Статья поступила в сентябре 2015 г.

\section{Рецензенты:}

Юрчак Д. В. - кандидат исторических наук, доцент кафедры истории Беларуси Витебского государственного университета имени П. М. Машерова;

Шарапо А. В. - доктор исторических наук, профессор кафедры международных отношений факультета международных отношений Белорусского государственного университета. 


\title{
АНАЛИЗ КОНТАКТОВ РУКОВОДИТЕЛЕЙ \\ СССР И ВЕЛИКОБРИТАНИИ (1941-1945 Гг.)
}

\author{
B. А. Лагун
}

магистрант Высшей школь экономики

Санкт-Петербург

УДК 327(47:410)(092) «1941/1945»

Международные и межгосударственные отношения - это в первую очередь взаимоотношения между индивидуумами, которые представляют свои государства, компании, организации и которые, кроме того факта, что являются уполномоченными представителями, являются еще и персоналиями, чье личное отношение к тому или иному событию может оказать значительное влияние на развитие ситуации. Особенно значение данный тезис приобретает в конфликтных ситуациях, в моменты кризиса или катастрофы, затрагивающей более чем одного актора международных отношений.

В таких случаях люди обращаются к моделям поведения, которые привычны и понятны из повседневности, осуществляя таким образом перенос модели поведения оппонентов в конфликтной ситуации на поведение международных субъектов в ситуации конфликта, напряженности или катастрофы. Нередко в такой ситуации личные предпочтения человека, находящегося у власти, влияют на внешнеполитические направления, разрабатываемые в этот период, а приоритеты внешней политики подвергаются корректировке исходя из индивидуального восприятия ситуации и других сторон конфликта.

Вторая мировая война - период взаимоотношений трех сильных личностей, которые определяли настоящее и будущее всего мира. И, что особенно примечательно, каждый из этих лидеров был представителем новой системы взаимоотношения ветвей власти внутри государства.

Несмотря на то что Великобританию и США в контексте сотрудничества с СССР во время Второй мировой войны часто рассматривают единым блоком, именно разница во внутренней процедуре принятия решений и влияния лидера на данные решения кажется наиболее важным моментом в трехстороннем сотрудничестве. В данной статье рассмотрена советско-британская грань сложного и нерав- 
ностороннего дипломатического треугольника - неоднозначный процесс выстраивания личных и политических взаимоотношений между И. Сталиным и У. Черчиллем, выраженный в переписке, выступлениях двух лидеров и мемуарной литературе. Интерес к данному аспекту обусловлен личностями, представляющими разные системы государственного управления и разные культуры, однако вынужденными волей обстоятельств сотрудничать на протяжении четырех лет.

Анализ переписки глав государств-союзников позволил выявить закономерности и эволюцию отношений союзников, а также влияние личных взаимоотношений У. Черчилля и И. Сталина на официальные политические курсы советского и британского государств в период Второй мировой войны.

Одна из задач автора - обоснование важности личных контактов в решении государственных и международных вопросов, особенно в условиях вооруженного конфликта. В результате анализа писем была представлена схема (матрица) переписки государственных деятелей, позволяющая оценить историческое влияние личностных отношений на международные и межгосударственные связи.

Основным источником исследования стала «Переписка И. Сталина с У. Черчиллем и К. Эттли (июль 1941 г. - ноябрь 1945 г.)» под редакцией Н. Старикова [7].

В российской и зарубежной историографии немало работ, посвященных союзникам и их взаимодействию, среди них можно выделить четыре подгруппы:

1) исследования, которые затрагивают вопросы построения советско-британских отношений без акцента на военных вопросах (Е. John [18], В. Шестаков [15; 16] и др.);

2) исследования, которые затрагивают узкие вопросы, упоминаемые в переписке или на личных встречах союзников по антигитлеровской коалиции (например, В. Fischer [19], J. Nosek [20] и др.);

3) исследования, основной темой которых стала военно-политическая сторона развития взаимоотношений союзников по антигитлеровской коалиции (В. Печатнов [9], А. Васильев [3] и др.);

4) исследования, описывающие советско-британские отношения через призму личности (Б. Тененбаум [13], Э. Радзинский [10] и др.).

Основной источник данной статьи - письма лидеров друг к другу, опубликованные в книге «Переписка И. Сталина с У. Черчиллем и К. Эттли (июль 1941 г. - ноябрь 1945 г.)» [7]. Это не первое и не 
единственное издание переписки на русском языке, все издания переписки идентичны первому изданию (1958 г.). Книга содержит переписку Черчилля и Сталина, поскольку переписка с Рузвельтом началась позже и вошла во второй том издания.

Издание 2015 г. отличает предисловие Н. Старикова, которое, несмотря на некоторую идеологическую окраску, было частично использовано при написании данной статьи.

Переписка расположена хронологически с первого письма (признанного таковым, поскольку два действительно первых письма не признавались советской стороной как неотъемлемая часть эпистолярного наследия Великой тройки). В каждом письме сохранены подписи и обращения, которые были использованы автором в анализе, однако все письма приведены в переводе на русский язык (если применимо), а также снабжены комментариями, позволяющими расположить их относительно событий истории Второй мировой войны.

Переписка служит ценным источником информации, поскольку позволяет увидеть процесс ведения переговоров таким, каким он был на самом деле. Если стенография либо записи бесед представляют результат работы и переработки стенографистки или секретаря, переписка дает доступ к тексту и мыслям напрямую и возможность оценить атмосферу эпистолярной части сотрудничества. В то же время в письмах отражается подсознательное желание создания образа, приятного собеседнику.

В процессе работы использовались различные подходы, объединяющие методы нескольких дисциплин. Попытка разработать систему, предпринятая автором, позволяет единообразно подходить к изучению посланий, написанных на разные темы и разными людьми, что дает возможность сравнивать послания между собой на основе одинаковых или максимально приближенных критериев. В работе при опоре на исследования в сфере политической лингвистики были использованы преимущественно языковые инструменты, такие как анализ лексического аппарата и анализ грамматических конструкций русского (англоязычные послания исследовались в переводе) языка, применялись элементы стилистического анализа, а также методы теории международных отношений, которые уделяют особое внимание личности в международных отношениях.

Анализ основывается на блоках вопросов (матрице), которые ставятся к тексту послания и могут дополняться комментариями, до- 
полнительными вопросами. Согласно данной идее оценка послания происходила в три этапа:

1) стилистическая и лексическая оценка послания, оценка его структуры;

2) анализ содержания;

3) обзорный анализ послания.

Первый этап представляет собой оценку языка и выражений, которые используются автором послания, их соответствие ситуации и языку автора в других ситуациях (например, проводится сравнение с публичными выступлениями, написанными текстами, перепиской с другими лицами). Особое внимание уделяется метафорам и идиоматическим выражениям, а также выражениям, характерным для данной культуры, демонстрирующим культурно-исторические различия между корреспондентами. Также уделяется внимание наличию или отсутствию обращений, других способов персонализации послания, эмоциональности и официальности текста. Уделяется внимание штампам и языковым клише, особенно цели их использования (желание избежать перехода на личности, момент обещания или объяснения в случае невыполненного обещания и т. п.).

На втором этапе можно выделить основные моменты, на которые обращалось внимание. В первую очередь это обсуждаемый вопрос: манера подачи и система фактов, окружающая вопрос, способ их предоставления, наличие (отсутствие) анализа, цель послания и упоминания данного вопроса, контекст. Использование комбинации этих моментов позволяет обратить внимание на отличия в представлении одних и тех же вопросов во всем процессе переписки. В рассматриваемой переписке особенно ярко это видно в обсуждении поставок, поскольку этот вопрос поднимался особенно часто и облекался в разные формы: просьбы, требования, завуалированный или открытый шантаж, другие способы давления.

На третьем этапе послание оценивалось как составляющая переписки, а также с учетом исторического контекста. Это позволяет понять цели и мотивы, а также объяснить некоторые частные вопросы, обсуждаемые в послании. Кроме того, на данном этапе есть возможность сравнить образ автора послания с образом, который сложился до этого, а также образ, который рисовался у читающего данное послание. Последний этап оценки не относится напрямую к оценке послания, однако он помогает понять письмо. 
Сначала необходимо обратиться к личностям, ведущим переписку, чтобы сформировать отправную точку, согласно которой можно оценивать изменение межличностных отношений в процессе переписки. Для этого следует обратиться к биографии (Б. Тененбаум [13], Э. Радзинский [10]) или, что касается жизни британского премьер-министра, к книгам, посвященным Черчиллю, а также книге «Вторая мировая война», написанной им самим. На основе предварительного исследования можно сказать, что оказавшиеся в достаточно тесных рабочих отношениях в ситуации войны с нацистской Германией лидеры СССР и Великобритании имели не только разную биографию и путь к власти, но и разный взгляд на мир, зачастую диаметрально противоположный. Разные исторические и культурные миры, в которых формировались личности Сталина и Черчилля, усложняли процесс переговоров и срывали попытки достичь соглашения, что отражено в переписке.

Такой разный подход к одинаковой ситуации ярко виден на примере самой острой темы, составляющей больше половины объема посланий, - темы второго фронта. Так, в письме к Черчиллю от 3 сентября 1941 г. Сталин в который раз за первые месяцы возвращается к этому вопросу, прописывая подробный план помощи, требуемой Красной Армии, в том числе и от Англии, и отмечая: «Я понимаю, что настоящее послание доставит Вашему превосходительству огорчение. Но что делать? Опыт научил меня смотреть в глаза действительности, как бы она ни была неприятной, и не бояться высказать правду, как бы она ни была нежелательной» [7, с 25].

Подкупило ли такое понимание Черчилля - не известно, однако в ответном письме начинается обсуждение возможной даты открытия фронта в Европе: Черчилль осторожно упоминает 1942 год, несколько раз подчеркивая, что все это «зависит от событий, которые трудно предвидеть» [7, с. 27]. Обсуждения подобного рода встречаются довольно часто, и они достаточно однотипны: Сталин просит или требует открытия второго фронта, а Черчилль, в одиночку или поддерживаемый Рузвельтом, приводит аргументы, почему данная операция невозможна, трудноосуществима или пагубна для состояния английской армии.

Это подтверждает разницу в восприятии человеческой жизни в войне в СССР и на Западе, именно на этот фактор часто ссылался британский премьер-министр, повторяя из письма в письмо, что вы- 
садка войск в Европе будет стоить «слишком больших жертв». Сталин таких аргументов понять не мог потому, что советское сознание того времени ставило человека и жизнь ниже целей общества и государства. Поэтому он такие аргументы считал отговорками, о чем периодически заявлял, не удовлетворяясь ни обоснованиями союзников, ни другими операциями, готовящимися к началу.

Другой пример - это обсуждение операции «Эскимос» в письмах 123-129 в марте 1943 г., которое постоянно сводилось Сталиным к обсуждению открытия Западного фронта во Франции: «По-прежнему я считаю главным вопросом - ускорение открытия второго фронта во Франции. <...> Вами допускалось открытие второго фронта еще в 1942 году <..> понятно поэтому, что в предыдущем послании я подчеркивал необходимость осуществления удара с Запада не позже чем весной или в начале лета этого года» [7, с. 118]. Такая настойчивость в результате оправдалась, принеся некоторое облегчение советским войскам и славу Сталину как тяжелому партнеру по переговорам. Такое упрямство скорее объединяло Черчилля и Сталина, хотя не облегчало переговорный процесс.

Еще одной объединяющей чертой двух лидеров и партнеров по переписке можно считать чувство юмора, замеченное исследователем жизни и творчества Черчилля В. Шестаковым: «B отличие от устрашающего юмора Сталина, юмор Черчилля никогда не был разрушительным и ииничным. Он мог поражать, но не уничтожать. <... Он скорее напоминает английскую карикатуру XVII века, <..> английский любовный или исторический роман〉 [15, с. 118]. Согласиться с такой спорной трактовкой сложно, особенно в атмосфере противоречивого отношения к И. В. Сталину, которая не учитывает социальные и культурные различия, в которых существовали два лидера. В. Шестаков опирается на одну из встреч, описанную Черчиллем в мемуарах, забывая, что, во-первых, они писались уже после окончания тесного сотрудничества, когда Советская Россия снова начала приобретать статус противника.

Во-вторых, это значит, что для Черчилля Россия, а значит и личность Сталина как ее представителя, была загадкой, к разгадке которой он так и не смог приблизиться, несмотря на четырехлетнее тесное сотрудничество. Однако отрицать тот факт, что оба лидера обладали ярким чувством юмора, которое ценили друг в друге, не следует, поскольку переписка и протоколы встреч, несмотря на нешуточные те- 
мы, показывают и моменты личного общения, характеризующие отношения двух лидеров.

«- Да поможет Вам Бог, - сказал Сталин.

- Бог, конечно, на нашей стороне, - согласился Черчилль.

- Ну а дьявол, разумеется, на моей, и объединенными усилиями мы победим врага, - подхватил Сталин» [2, с. 316-317].

Этот диалог показателен потому, что речь Черчилля в эфире радио, где он утверждает, что «если Гитлер вторгнется в ад, я дам дьяволу самые лестные отзывы в палате общин» [21, с. 761], была известна Сталину и воспринята им с долей юмора, что противоречит многим политическим портретам Сталина как жадного к власти, агрессивного и не выносящего шуток в свой адрес тирана.

Иногда, несмотря на серьезность обсуждаемых вопросов, Черчилль и Сталин позволяют себе достаточно пространные язвительные замечания, свойственные письмам между хорошо знакомыми и вынужденными доверять друг другу сторонами. Для примера подойдет письмо № 198, полученное Сталиным 27 сентября 1943 г., в котором Черчилль позволяет себе такую фразу: «...мы будем иметь эффективную ширму от мировой прессы, а также от каких-либо неприятных людей, которым мы не так нравимся, как должны были бы нравиться» $[7$, с. 184].

В определенные моменты взаимоотношения, особенно ту сторону, которая отражена в переписке, можно назвать дружескими, однако необходимо учитывать и исторический контекст, и персональную историю лидеров, которые подтверждают, что такое определение было бы преувеличением. Формировавшиеся долгие военные годы отношения прошли три стадии, границы которых основаны в основном на стилистике и разнице в используемой лексике.

В самом начале переписки послания Черчилля, написанные высоким классическим стилем, богаты предложениями помощи и идеями развития сотрудничества, демонстрируют заинтересованность Черчилля в происходящем на русских фронтах. Премьер-министр выражает восхищение мужеством солдат, удачными боями советских армий, не упуская возможности подчеркнуть героическую помощь Англии, ее и свой личный вклад в будущую победу. Развернутые, богатые на оговорки и сравнительные пассажи письма Черчилля многочисленны, их количество превышает количество посланий, отправленных Сталиным, однако это объясняется тем, что большинство по- 
правок, пожеланий и сообщений передавались через посольства либо напрямую через доверенных лиц.

От писем британской стороны опубликованные послания лидера Советского Союза, особенно в первые несколько месяцев, сильно отличаются, они имеют исключительно деловую направленность и не превышают лимита учтивостей, положенного протоколом и вежливостью. Четкие, выверенные предварительно Молотовым, а затем повторно лично Сталиным выражения не выражают никаких эмоций и предназначены исключительно для решения деловых вопросов и обсуждения возможных разногласий.

Тем не менее постоянная переписка и необходимость сплотиться перед лицом общего врага постепенно смягчают стиль письма. Официальные послания, например сопроводительное письмо британского премьера лорду Бивербруку для британской и американской миссий в сентябре 1941 г., приобретают черты дружеского напутствия, подкрепленного заверениями в скорой совместной победе над «нацистскими тиранами» и неожиданно эмоциональной подписью: «Верьте мне, искренне Ваш Уинстон Черчилль» [7, с. 31-32], мало свойственной предыдущей и последующей переписке. Такое искреннее послание не могло не остаться без ответа, и ответ Сталина также отличался вежливостью и расширенными формулами приветствия и прощания, хотя и более скромными [7, с. 33-34].

В последующем стиль достигает уровня, который заметен в процитированном сентябрьском послании, что позволяет утверждать, что третий этап, условно названный завершающим, характеризуется более открытыми и искренними письмами, меньшим количеством канцеляризмов и дипломатических штампов.

Возможно, немалую роль в установлении доверительных и устойчивых отношений сыграл второй по количеству обсуждения вопрос, который хоть и вызвал споры внутри Англии, но не имел для Черчилля такой остроты, как вопрос второго фронта, поскольку не затрагивал интересов Британии. Это позволяло Черчиллю легко идти на уступки, а Сталину следовать той стратегии, к которой он стремился с самого момента установления взаимных отношений путем личных посланий. На протяжении переписки тезис о быстром решении кризисных моментов является ключевым для Сталина, и он не раз подтверждает это, обращаясь к Черчиллю с настойчивыми пожеланиями решения той или иной проблемы, подталкивая его к лично- 
му вмешательству и использованию авторитета в решении проблемы, он даже подчеркивает это списочной структурой многих своих писем. Особенно это заметно в попытках урегулирования так называемого польского вопроса.

Здесь Черчилль проявляет уступчивость, которую можно ошибочно принять за результат давления Сталина или за результат дружеских отношений. Однако это скорее всего было просто удобной и не затратной возможностью продемонстрировать Сталину желание сотрудничать, действовать в интересах друг друга. В одном из посланий (письмо № 159 в «Переписке...») он соглашается лично попытаться изменить мнение Сикорского о вопросах формирования польского правительства.

Гипотезу, что активная переписка, направленная на обсуждение польского вопроса, благотворно повлияла на личные взаимоотношения двух лидеров, подтверждает В. Шестаков в книге «Уинстон Черчилль: интеллектуальный портрет». «B период между Тегеранской $и$ Ялтинской конференциями, который продолжался 14 месяцев, отношения между Черчиллем и Сталиным оживились <... В октябре Черчилль лично приезжает в Москву и проводит здесь десять дней. На этот раз он чувствует себя здесь более уверенно, тем более что Сталин явно благоволит своему гостю. Он сопровождает его в Большой театр, присутствует на ланче в британском посольстве (чего никогда не делал до сих пор), провожает его в аэропорт. Черчилль уезжает из Москвы явно довольный и пишет Сталину благодарственное письмо от имени “друга и товарища по войне”» [15, c. 118]. Данный тезис также подтверждается несколькими письмами после конференции и поздравительным посланием Черчилля Сталину, полученным 20 декабря 1943 г., в котором он называет его «мой друг» и в ответ на которое Сталин, «сердечно благодарный за дружеское приветствие по случаю дня рождения», участливо интересуется состоянием здоровья, по-видимому, приболевшего в тот период британского премьера [7, с. 199]. Последующие несколько писем неизменно включают несколько фраз о здоровье британского лидера, поддерживая атмосферу дружественного доверительного общения, а заявления о теплых дружеских отношениях появляются также в письме Черчилля Тито в Югославию, подкрепляясь знакомой подписью «Верьте мне, искренне Ваш Уинстон С. Черчилль» и горячей поддержкой и одобрением Сталина [7, с. 204]. 
Исходя из этого, следует отметить, что переписка двух лидеров перед конференцией в Тегеране и сразу после нее крайне эмоциональна и активна, многие ее моменты по-новому открывают личность Сталина, позволяют отойти от стереотипа кровавого тирана и убийцы миллионов соотечественников, каковым его видят многие исследователи и на постсоветском пространстве, и за рубежом.

Период, предшествующий Тегеранской конференции, и три месяца после ее завершения можно назвать кульминационным в советско-британских отношениях в период Второй мировой. После него до Ялтинской конференции переписка проходит в умеренно дружеском тоне, который не портят даже периодические столкновения по стратегическим вопросам.

Подобный тон пронизывает и завершающий этап переписки период, незначительно предшествующий началу операции «Оверлорд», которая позволила открыть в Европе второй фронт. В этот период тон отношений между Черчиллем и Сталиным достаточно ровный, его условно можно разделить на два подпериода, каждый из которых имеет качественные характеристики. Так, первый из них, условно начинающийся весной 1944 г. и продлившийся до середины весны 1945 г., захватил исключительно важную для поствоенного устройства встречу Сталина, Черчилля и Рузвельта в Москве в октябpe 1944 г. [12] и Ялтинскую конференцию февраля 1945 г. Взятие Берлина фактически закончило войну для Советского Союза, и для большинства европейских стран это также стало завершающим этапом военных действий. Радость победы и осознание того, что эту победу принесла совместная борьба против Гитлера, еще какое-то время сохранялись. Однако политические лидеры уже начинали перестраивать существовавшую во время войны модель восприятия мира и союзников, осознавая, что СССР был лишь временным другом и дальнейшие отношения могут быть основаны на строгом нейтралитете и взаимном сдерживании. Таким образом, второй подпериод во взаимоотношениях союзников, начавшийся весной 1945 г., можно назвать периодом «сворачивания» дружбы.

Оба этих подпериода богаты на письма, им уделено особое внимание в мемуарах Черчилля и посвящено несколько глав в исследовании О. А. Ржешевского «Черчилль и Сталин» [11]. Эмоционально яркие письма (первый подпериод выделяет язык переписки, который приобретает особую эмоциональность, становится еще менее фор- 
мальным, более личным) и частые встречи также обогащают первый подпериод в отличие от второго. Период в целом смотрится гармоничным завершением достаточно успешного сотрудничества внешне и внутренне очень различных акторов международных отношений.

Примечателен язык переписки данного периода. Вместо взвешенных и обтекаемых фраз начального периода, осторожных шуток и дружеских порывов среднего периода в 1944 г. в письмах видно отсутствие строгой цензуры, в том числе и внутренней цензуры авторов. Язык посланий становится более естественным, образность, присущая Черчиллю, содержит все меньше громких, типичных для публичных выступлений сравнений и оборотов, а Сталин, наоборот, употребляет больше сравнений и метафор [1], позволяя себе смелые исторические параллели в сторону союзников, выходя за рамки протокольной вежливости.

Ньнешняя кучка престарельх и голодных политиканов, естественно, будет стараться протолкнуть итальянские притязания... $[17$, c. 278$]$.

... Наполеон в свое время позорно провалился со своим планом форсировать Ла-Манш. Истерик Гитлер, который два года хвастал, что он осуществит форсирование Ла-Манша, не решился сделать даже намек на попытку осуществить свою угрозу. Только нашим союзникам удалось с честью осуществить [этот] грандиозный план... [7, с. 279].

Выделенные обороты нетипичны для переписки такого уровня, равно как и упомянутое в том же письме Сталина одобрение возможного американского решения о том, «что Италии надо иметь другое правительство, а не правительство Бономи» [7, № 279].

Таким образом, можно отметить изменение оттенков отношений между двумя лидерами, применив предложенную Дж. Розенау в 1971 г. схему. Она включает шесть уровней анализа системы международных отношений, в центре которой - личность и ее влияние на международные отношения. Первый уровень данной системы - это индивиды - творцы политики и их личностные характеристики; второй уровень - профессиональная сторона личности - занимаемые посты, должности, выполняемые социальные роли; третий уровень структура правительства государства, в котором данные личности действуют, система взаимоотношений между государственными органами, структурными подразделениями государственного аппарата; 
четвертый уровень - это общество, в котором политические творцы существуют, которым управляют и чьи интересы представляют на международной арене; пятый уровень выходит за рамки национального государства и представляет его взаимоотношения с внешними акторами - другими национальными государствами, международными организациями и другими акторами международных отношений. Последний - шестой уровень - представляет самый широкий уровень анализа - анализ международной системы [5].

Обратив внимание на первый и четвертый уровни, а также применив анализ семантического пространства языка (языковой картины мира) [6], можно говорить об окончательном формировании дружественных, в меру доверительных отношений, т. е. к подсознательному отходу от формулы «временный союзник из бывшего врага» ради формулы «равноправный партнер», что подтверждают и решения 4-й Московской конференции союзников, в частности так называемое «Соглашение о процентах» между Черчиллем и Сталиным [12].

Период побед союзников, а затем и открытие второго фронта в Европе воодушевило обе стороны на взаимные уступки, снизив появившееся ранее напряжение из-за польского вопроса. Значительно возрастает и частота писем: операция «Оверлорд» интересна Сталину, ему важны подробности как на стадии подготовки, так и с момента ее начала. Если судить из новостей, преобладающих в переписке, 1944 год выдался удачным для обеих сторон, взаимные поздравления и обмен радостными известиями о победах встречаются практически в каждом письме, часть из них состоит исключительно из поздравлений и взаимных восхищений победами союзнических армий [7].

Второй подпериод можно охарактеризовать как спад, постепенное утихание переписки, особенно моментов личного характера и установление спокойного равнодушия в отношения партнеров. Послания сконцентрированы на передаче информации и разрешении насущных вопросов, подготовке к заключению мирных договоров, обсуждении положения в различных частях планеты, но они представляют собой сухой пласт информации. Даже витиеватая речь Черчилля теряет краски, что может говорить и о равнодушии, и об отсутствии необходимости более потакать Сталину ради решения каких-либо военных задач. Тем не менее тон писем по-прежнему уважительно-дружелюбный и достаточно открытый с обеих сторон. Это позволяет утверждать, что определенные личные отношения построены и несмот- 
ря на то что вот-вот оба лидера снова окажутся по разные стороны «железного занавеса», они не испытывают друг к другу личностной неприязни. Возвращается привычный для первого этапа формат переписки, когда Сталин писал одно длинное письмо на группу посланий Черчилля или же отвечал кратко, что больше похоже на кивок в устной речи, показывая, что информация получена и учтена.

Последнее письмо Черчилля Сталину датировано 12 июля 1945 г. и содержит письмо Риббентропа и комментарий к нему: «Я думаю, что его [письма] содержание отчасти представит для Вас интерес, хотя оно очень длинное и скучное» [7, с. 413]. Интересна характеристика прилагаемого документа, недопустимая ни на начальном этапе переписки, ни на более зрелом ее этапе. Можно предположить, что такой тон обусловлен победой - пусть еще не окончательной, но уже очевидной.

Однако еще слишком много вопросов предстояло решить, и предположить, что Черчилль этого не учитывал, было бы сильным отступлением от портрета, складывающегося на основе переписки и сторонних источников. Таким образом, можно считать, что Черчилль был достаточно уверен в выстроенных отношениях, чтобы позволить себе такой тон.

Следующее письмо Сталин получает уже от К. Эттли. Стоит отметить, что краткая переписка Сталина и К. Эттли по тону и манере соответствует самым первым письмам между Сталиным и Черчиллем. Это позволяет утверждать, что определенное влияние на межправительственные советско-британские связи оказала именно личная переписка двух лидеров, длившаяся весь период Второй мировой войны.

Подводя итог, следует отметить, что разделение переписки на три этапа достаточно условно, и четкую границу провести сложно. Однако выделение приблизительных этапов переписки, а соответственно и взаимоотношений товарища Сталина и премьера Черчилля, позволило создать четкую картину изменений за описанный период, т. е. продемонстрировать прогресс взаимоотношений, подчеркнуть факторы, повлиявшие на их становление и формирование на личностном уровне, который впоследствии сыграл важную роль в решении политических и военных задач. В частности, из переписки видно, как менялись отношения лидеров, каким образом это отражалось на стилистике, построении и даже длине и частоте посланий. 
Кроме того, при наложении на исторический контекст становятся понятными периоды холодности и оттепели в отношениях, что позволяет составить наиболее полную картину отношений между государствами - участниками антигитлеровского союза.

В результате изучения переписки появилась возможность проследить, как личные отношения влияли на решение спорных вопросов, однако утверждать, что именно они формировали официальные политические курсы советского и британского государств в период Второй мировой войны, было бы ошибочно, поскольку взаимоотношения лидеров этих стран были фактом скорее вынужденным, нежели добровольным.

Тем не менее, данное сотрудничество повлияло на развитие сношений между странами, и, если учитывать, что в Советском Союзе вопросы дипломатических отношений зависели от воли одного человека, отрицать, что личное общение между Черчиллем и Сталиным не стало катализатором будет неправильным.

Таким образом, влияние личных отношений было частичным и в некоторой степени односторонним, однако не служило решающим фактором начала советско-британского и британо-советского сотрудничества во время Второй мировой войны ни для одной из сторон, хотя и имело определенную важность в процессе принятия решений и обсуждения текущих задач и проблем.

\section{Библиографические ссылки}

1. Базылев В. Н. Сталинские дискуссии : дискурсные параллели // Полит. лингвистика. 2014.- № 2 (48). - С. 23-29.

2. Бережков В. Как я стал переводчиком Сталина. - М., 1993. - С. 400.

3. Васильев А. Ф. Был ли в 1941 г. Советский Союз готов к войне? // Вопр. истории. - 2004. № 11. - С. 105-110.

4. Великие властители прошлого : переписка Сталина с Черчиллем и Этли, Рузвельтом и Труменом во время Великой отечественной войны // Militera.lib [Электронный pecypc]. URL : http://militera.lib.ru/docs/da/stalin_perepiska/index.html. (дата обращения : 05.04.2015).

5. Волкогонов Д. Предисловие к книге «Черчилль У. Вторая мировая война». - М., 1991.

6. Карасик В. И. Языковой круг: личность, концепты, дискурс. - Волгоград : Перемена, 2002.

7. Переписка И. Сталина с У. Черчиллем и К. Эттли (июль 1941 г. - ноябрь 1945 г.) / предисл. Н. Старикова // Николай Стариков рекомендует прочитать. - Спб. : Питер, 2015. 
8. Печатнов B. Как Сталин и Молотов писали Черчиллю // Россия в глобальной политике [Электронный ресурс]. - 2009. - URL : http://www.globalaffairs.ru/number/n_13638. (дата обращения : 12.03.2015).

9. Печатнов В. Переписка У. Черчилля с И. В. Сталиным в годы Великой Отечественной войны // International Affairs. - 2010 - № 7. - С. 73-96.

10. Радзинский Э. Сталин. Жизнь и смерть. - М. : АСТ, 2011.

11. Ржешевский O. А. Сталин и Черчилль. - М. : Эксмо: Алгоритм, 2010.

12. Советский Союз на международных конференциях периода Великой Отечественной войны 1941-1945 гг. : сб. науч. ст. - М. : Политиздат, 1984.

13. Тененбаум Б. Великий Черчилль. - М. : Яуза: Эксмо, 2012.

14. Черчилль У. Вторая мировая война. - М. : Воен. изд-во, 1991.

15. Шестаков В.П. Уинстон Черчилль : интеллектуальн. портрет. - М. : Форум, 2011.

16. Шестаков В. П. Черчилль и Сталин // Полит.ру [Электронный ресурс]. - URL : http://www.polit.ru/article/2004/04/19/cherch/ (дата обращения : 12.03.2012).

17. Churchill W. S. The Second World War. Vol. 1-6. - London, Boston, Toronto : Cassel, Houghton Mifflin, 1983.

18. Ellis J. Brute Force. Allied Strategy and Tactics in the Second World War. - N. Y. : Penguin Group, 1990.

19. Fischer B B. The Katyn Controversy : Stalin's Killing Field // Studies in Intelligence. - 19992000.

20. Nosek J. Winston Churchill's Use of Methafors / translated by T. Zybakina // Полит. лингвистика. - 2012. - № 1 . - С. 1-6.

21. Robert R. J., M.P. Churchill Speaks. 1897-1963. Collected speeches in peace and war. - N. Y. : Barnes \& Noble books, 1998.

22. Roberts J. Stalin's Wars From World War to Cold War, 1939-1953. - New Haven : Yale University Press, 2007.

23. Weidhorn M. A. Harmony of Interests. Explorations in the Mind of Sir Winston Churchill. New York, 1992.

\section{Анализ контактов руководителей СССР и Великобритании (1941-1945) (Владислава Лагун)}

В статье рассматриваются взаимоотношения между У. Черчиллем и И. Сталиным на основе опубликованной переписки; выделяются этапы, характеризуются их особенности и обсуждаемые в переписке вопросы. Анализируются лексические, стилистические и грамматические средства, использованные сторонами при написании посланий. Анализируется значимость личных взаимоотношений лидеров для развития отношений двух стран с различной историкокультурной традицией в период кризиса. 


\section{Ключевые слова}

Черчилль; Сталин; взаимоотношения между лидерами; военнополитическое сотрудничество; дипломатия; Вторая мировая война.

The impact of the personal contacts between leaders on the bilateral relations of the USSR and the UK in 1941-1945 (Uladzislava Lahun)

The article discusses the relationship between W. Churchill and J. Stalin based on the published correspondence; author formulate periods, characterize their particularities and discussed issues. Moreover author analyze lexical, grammar and stylistic tools used in the creation of the messages. In the article author assess the meaning of the personal relations between country political leaders, who came from different cultural and historical background, in the situation of the crisis.

\section{Key words}

Churchill; Stalin; interpersonal relations; political and military cooperation; diplomacy; Word War II.

Статья поступила в сентябре 2015 г.

\section{Рецензенты:}

Шадурский В. Г. - доктор исторических наук, декан факультета международных отношений Белорусского государственного университета, профессор;

Есин Р. О. - доктор политических наук, профессор кафедры международных отношений Академии управления при Президенте Республики Беларусь. 


\section{СРАВНЕНИЕ ТЕОРЕТИЧЕСКИХ ОБОСНОВАНИЙ ПРИОРИТЕТА ТЕРРИТОРАЛЬНЫХ ПРАВ \\ ГОСУДАРСТВА И НАЦИИ}

\section{А. С. Матвиенко}

кандидат политических наук, докторант

Института государства и права имени В. М. Корецкого НАН Украинь

УДК 342.1

В международном праве территория понимается как пространственная сфера действия государственного суверенитета, сфера территориальной юрисдикции государства. Как следует из доклада Комиссии международного права $\mathrm{OOH}$, в международном праве под территорией понимаются «области, над которыми государство осуществляет суверенную власть» [1]. В состав государственной территории входят: сухопутная территория (поверхность суши), включая острова; водная территория (акватория), включающая внутренние воды и территориальное море; земные недра; воздушное пространство, расположенное над перечисленными пространствами [2].

Территориальное верховенство является одной из важных характеристик государственного суверенитета, предусматривающей высшую, полную и исключительную власть государства на своей территории.

Такое понимание связано с концепцией Вестфальского суверенитета, закрепившей за государством полное верховенство в пределах его территории, политическую независимость во внутренней и внешней политике, юридическую равноправность в международных отношениях.

Дж. Симмонс выделил пять основных составляющих территориальных прав [3]:

- право осуществлять юрисдикцию (полную или ограниченную) над всеми, находящимися на его территории индивидами, контролировать их и принуждать к некоторым действиям, даже неграждан;

- право полного контроля над землей и ресурсами в своих границах, не относящихся к частной собственности;

- право устанавливать налоги и регулировать экономическую деятельность частных лиц, пребывающих на территории государства; 
- право контролировать или запрещать движение через свои границы;

- право ограничивать или запрещать деление государственной территории.

Как правило, большинство этих прав сводится к юрисдикции, тесно связанной с понятием суверенитета и определяющей объем и сферу действия государственной власти. Проект Декларации прав и обязанностей государств, рассмотренный Генеральной Ассамблей ООН в декабре 1949 г., закрепил за государствами право «осуществлять юрисдикцию над своей территорией и над всеми лицами и вещами, находящимися в ее пределах, с соблюдением признанных международным правом иммунитетов» [4] (ст. 2). От государств ст. 11 Декларации требует воздерживаться от признания каких бы то ни было территориальных приобретений другого государства, полученных силой. Существуют различные походы к ее классификации, например:

- по объему: полная (позволяет устанавливать правила поведения и обеспечивать реализацию своих предписаний всеми имеющимися в его распоряжении законными средствами) и ограниченная (дает возможность устанавливать правила, но предполагает меньший арсенал средств для обеспечения их выполнения);

- по сфере действия (территориальная, экстерриториальная - в отношении своих граждан, пребывающих за границами государства),

- по характеру власти (законодательная, судебная, исполнительная);

- по субъектам: государственная (территориальная и национальная) и международная.

Однако редуцировать территориальные права только к юрисдикции было бы слишком просто, давая основания рассматривать их исключительно как право на коллективную собственность. Это в свою очередь ограничивает наше понимание природы территориальных прав. Так, если принять точку зрения таких сторонников концепции глобальной справедливости, как Дж. Брок [5], Д. Мелленфорд [6], К. Тан [7], то следует признать, что ресурсы Земли принадлежат всему человечеству. Следовательно, ни одно государство не может предъявлять претензии на их единоличную добычу и использование, если не будет подписано взаимное соглашение между сторонами, предусматривающее уплату государством некоего глобального нало- 
га в обмен на получение полных прав над ресурсами. Исходя из этой же позиции, государство хотя и имеет юрисдикцию над всеми физически присутствующими на территории людьми, но не может решать, кто может пересекать ее границы или же должен покинуть территорию страны.

Традиционно территория рассматривается как взаимосвязь между частью земли, группой людей, проживающих на ней, и политическими институтами, управляющими этими людьми на данной земле. Соответственно, первым возникает вопрос о том, кому принадлежит приоритетное право на землю: людям, проживающим на ней, или государству, управляющему ими. Если принять вторую точку зрения, то следует вопрос о том, владеют ли государства территориальными правами непосредственно или косвенно, как представители народа, которым они управляют.

В литературе встречаются два основных похода к пониманию приоритета территориальных прав: одни исследователи закрепляют его за физическими лицами или группой лиц, а другие - за государством и его институтами.

Сторонники права индивидов считают, что отдельные лица имеют право на владение частью земли и, объединяя свои владения, они создают территориальное право по отношению к ней. Свои позиции они обосновывают локковским пониманием собственности. Дж. Локк рассматривал два варианта возникновения таких прав. Первый, индивидуальный, формировался в результате реализации индивидами своего права на собственность. Владея землей, они составляли соглашение, позволяющее государству получить территориальную юрисдикцию над их индивидуальной собственностью [8]. Второй вариант предусматривал существование коллективного права, согласно которому группа лиц, в том числе в лице государства, может получить территориальные права на конкретную землю благодаря коллективному труду на земле [9].

Дж. Локк утверждал, что государство имеет право осуществлять юрисдикцию над определенной территорией, поскольку: 1) отдельные граждане имеют дополитическое, природное право на часть земли; 2) каждый из этих граждан уполномочил государство, отдав свою землю под его юрисдикцию. Как и другие приверженцы теории природных прав, Дж. Локк исходил из допущения о совместном владении землей: он утверждал, что ни один человек не ответственен за 
создание земельных ресурсов и, поскольку мы все равны, у нас есть равное право заявлять претензии на использование ее ресурсов. Идея общего владения касается важной проблемы в теории частной собственности: если земля является общей собственностью, то как можно владеть частной собственностью, не спросив разрешения у других собственников? Дж. Локк отвечает на этот вопрос тем, что мы получаем право на собственность одновременно с обязанностями по отношению к другим соблюдать эти права, обрабатывая кусочек земли до тех пор, пока это не наносит вреда другим [10].

Природное право собственности включает множество элементов, включая право использовать и получать выгоду от земли, осуществлять юрисдикцию над ней, контролировать вход и выход и т. П. Некоторые исследователи весьма критично воспринимают возможность применения концепции Дж. Локка, поскольку, как утверждает Т. Мейзельс, «все обращения к аргументации собственности и к работам Локка... не содержат прямого и неоднозначного применения аргументов Локка по поводу собственности... к национальному случаю» [11].

Периодически предпринимаются попытки обосновать применимость подхода Дж. Локка, дополняя их критериями свободы, стремления и эффективности [12].

Теория Дж. Локка, акцентирующая внимание на тесной взаимосвязи между собственностью и территориальными правами, также не способна дать ответ на несколько важных вопросов: 1) как государство может обеспечить неизменность состава своей территории, ведь собственники отдельных земельных наделов со временем меняются; 2) почему следующие поколения соглашаются принять юрисдикцию государства; 3) почему собственники земли, не согласные с коллективным договором, не могут выйти из государства?

Второй подход закрепляет приоритет территориальных прав непосредственно за государством или его образованиями. Обоснование такой трактовки содержится в трудах утилитаристов. По их мнению, государство претендует на территориальные права, поскольку оно может поддерживать порядок на территории и содействовать процветанию людей, проживающих на ней. Как отмечал Г. Сиджвик, «главным оправданием закрепления территории за правительством является предупреждение взаимного вреда между людьми, использующими ее, чего нельзя адекватно обеспечить другим способом» [13]. 
Однако поддержание социального порядка на надлежащем уровне является необходимым, но не достаточным условием получения государством права на территорию. Существуют другие способы достижения этой цели: поделить территорию между несколькими государствами, вступить в союз с другой страной. Следуя логике утилитаризма, можно утверждать, что если государство не может эффективно управлять общественными делами или делать это лучше, чем возможные конкуренты, то оно теряет право на территорию. Таким образом, создается возможность для оправдания сепаратизма или колониализма.

Но утилитаристы упускают из виду тот факт, что конкретное государство непосредственно связано с конкретной территорией. Следовательно, нужно сформулировать дополнительное условие легитимности, соединяющее государство с людьми, заселяющими территорию. Это приводит нас к так называемому кантовскому подходу. И. Кант утверждает, что государство имеет территориальные права в случае, если оно соответствует трем условиям: 1) государство эффективно осуществляет систему правового регулирования собственности на данной территории; 2) законодательная система отвечает минимальным требованиям для обеспечения согласия народа, гарантируя соблюдение их основных прав; 3) государство не является узурпатоpom.

В отличие от Дж. Локка немецкий философ настаивает на том, что подчинение юрисдикции государства - это единственный способ для индивида получить безусловные права собственности, то есть, не существует никаких природных прав собственности. Оправдание необходимости существования государства состоит в том, что право на собственность может быть согласовано с правами других людей только тогда, когда публичная власть устанавливает и поддерживает границы частных владений. И. Кант предполагал, что люди обязаны принять власть государства, чтобы эти связи с их собственностью были установлены.

Более того, они могут быть принуждены признать власть государства даже против собственной воли. Следствием этой позиции является то, что именно государство, а не индивиды или группы, имеет юрисдикцию над территорией. Право государства на территорию не происходит от делегирования ему прав индивидами, оно присуще ему изначально. 
Введение критерия легитимности, предложенное И. Кантом, позволяет лишить прав на территорию колонизаторов, не являющихся законными представителями народа, который они подчинили себе, даже если им удастся построить эффективное государство. Однако он дает шанс сепаратистам на создание нового образования, если они сумеют предоставить убедительные доказательства нелегитимности государства, в составе которого они пребывают.

Следует отметить, что критерии легитимности не сводятся к эффективному управлению, поскольку следует иметь в виду способ, каким государство получило право управлять народом, находящимся в его юрисдикции. А. Стилц утверждает, что народ, представляющий государство, имеет право проживать на земле, если: конкретный индивид проживает на ней сейчас или делал это раньше; законное проживание на территории имеет фундаментальный характер для целостности его структуры личных отношений, целей, поисков; его связь с конкретной территорией сформировалась не по его вине [14]. Последнее условие касается проблемы, связанной с захватчиками, которые изгоняют жителей с территории и создают собственное, внутренне легитимное государство вместо него. Захватчики могут жить на захваченной местности и начать выстраивание своих отношений, целей, поисков, но поскольку эти ожидания созданы в результате несправедливого развития событий - изгнания прежних жителей, имевших право на проживание, третье условие не выполнено и государство-захватчик не имеет территориальных прав.

Оба утилитаристских подхода к территориальным правам, представленные Г. Сиджвиком и И. Кантом, ориентированы на теперешнее состояние: их интересует выполнение государством, претендующим на эти права, критериев эффективности и легитимности на данный момент. Предыдущая история существования данного государства не учитывается, кроме возможности экстраполировать опыт выполнения им своих функций на настоящее и будущее.

Некоторые исследователи считают, что государство своими действиями в прошлом придает ценность земле, которой управляет, например путем создания стабильной системы сельского хозяйства. Тем не менее сложно согласиться с утверждением, что государство может претендовать на ценности, созданные в результате действий, предпринятых этим же государством, но в прошлом. Можно также утверждать, что государство, получив территориальные права, может поль- 
зоваться ими вечно, до конца своего существования. Такое утверждение сложно считать убедительным, поскольку каждый этап развития цивилизации имеет свои представления об эффективности и легитимности.

Таким образом, основная ошибка ученых, утверждающих о приоритете государства на территориальные права, состоит в том, что их критерии законности таких прав позволяют закрепить их за государством - захватчиком чужих территорий. Следовательно, нужно признать, что государство является легитимным представителем группы людей, нации, проживающей на данной территории, создающих конкретные государственные институты в соответствии со своими интересами и учетом международной обстановки. Таким образом, введение понятия нации, интересы которой представляет легитимное и эффективное государство, позволяет признать за ним приоритет территориальных прав.

\section{Библиографические ссылки}

1. Report of the Commission to the General Assembly on the work of its 46 session // Yearbook of the Iinternational law commission. - 1994. - Vol. 2, part 2. - P. 92.

2. Лукашук И. И. Международное право. Общая часть : учеб. для студ. юрид. фак. и вузов. М. : Волтерс Клувер, 2005. - С. 409-410.

3. Simmons J. On the territorial rights of states // Philosophical Issues. - 2001. - Vol. 11, № 1. P. 306.

4. Проект Декларации прав и обязанностей государств // daccess-ods.un [Электронный pecypc]. - URL : http://daccess-ods.un.org/TMP/8664929.27074432.html (дата обращения : 05.04.2015).

5. Brock G. Global justice : a cosmopolitan account. - Oxford : Oxford University Press, 2009.

6. Moellendorf D. Cosmopolitan Justice. - Boulder CO : Westview, 2002.

7. Tan K. Toleration, diversity, and global justice. - University Park PA : Penn State Press, 2001.

8. Rothbard M. N. For a new liberty : the libertarian manifesto. - San Francisco CA : Fox and Wilkes, 1978. - P. 26-37.

9. Meisels T. Liberal nationalism and territorial rights // J. of Applied Philosophy. - 2003. - Vol. 20, № 1. - P. 35.

10. Nozick R. Anarchy, state and utopia. - N.Y. : Basic Books, 1974; Steiner H. The natural right to the means of production // Philosophical Quarterly. - 1977. - Vol. 27. - P. 41-49.

11. Meisels T. Territorial rights. - Dordrecht : Springer, 2005. - P. 8.

12. Nine C. A Lockean theory of territory // Political Studies. - 2008. - Vol. 56, № 1. - P. 148-165.

13. Sidgwick H. The elements of politics. - L.: Macmillan, 1908. - P. 252.

14. Stilz A. Nations, states, and territory // Ethics. - 2011. - Vol. 121, № 3. - P. 585. 
Сравнение теоретических обоснований приоритета территориальных прав государства и нации (Анатолий Матвиенко)

Территориальное верховенство является одной из важных характеристик государственного суверенитета, что связано с концепцией Вестфальского суверенитета, закрепившей за государством полное верховенство в пределах его территории, политическую независимость во внутренней и внешней политике, юридическую равноправность в международных отношениях. Однако редуцировать территориальные права только к юрисдикции было бы слишком просто, давая основания рассматривать их исключительно как право на коллективную собственность. Это, в свою очередь, ограничивает наше понимание природы территориальных прав.

В специальной литературе существуют два основных подхода к определению приоритета территориальных прав: 1) локковский, указывающий на тесную взаимосвязь между правом собственности и территориальным суверенитетом; 2) кантовский, увязывающий территориальные права непосредственно с государством, его легитимностью и эффективностью. Объединение этих подходов дает основания для вывода, что государство является легитимным представителем группы людей, нации, проживающей на данной территории, создающих конкретные государственные институты в соответствии со своими интересами и учетом международной обстановки.

\section{Ключевые слова}

Территория; государство; собственность; легитимность; суверенитет; юрисдикция.

The theoretical justification of the priority of the territorial rights of the state and nation: a Comparative Analysis (Anatolij Matvienko)

Territorial sovereignty is one of the important characteristics of state sovereignty, which is associated with the concept of Westphalian sovereignty. This concept consolidates the right of state on supremacy its territory, political independence in domestic and foreign policy, the legal equality of international relations. However, the reduction territorial rights only to the jurisdiction it's simplification, which is giving reason to consider them only as collective property rights. This, in turn, limits our understanding of the nature of territorial rights. 
In the special literature there are two approaches to definition the priority of territorial rights: Lockean, identifying the close connection between property and territorial sovereignty; 2) Kantian, connecting territorial rights direct to state, its legitimacy and performance. Combining these approaches gives grounds for concluding that the state is a legitimate representative of a group of people, a nation living in the territory, creating specific government institutions in accordance with their interests and taking into account the international situation.

\section{Key words}

Territory; state; property; legitimacy; sovereignty; jurisdiction.

Статья поступила в сентябре 2015 г.

\section{Рецензенты:}

Решетников С. В. - доктор политических наук, профессор, заведующий кафедрой политологии Белорусского государственного университета;

Есин Р. О. - доктор политических наук, профессор кафедры международных отношений Академии управления при Президенте Республики Беларусь. 


\title{
НАЦИОНАЛЬНАЯ АКАДЕМИЯ НАУК БЕЛАРУСИ \\ В СИСТЕМЕ РАЗВИТИЯ МНОГОСТОРОННЕГО МЕЖДУНАРОДНОГО НАУЧНО-ТЕХНИЧЕСКОГО СОТРУДНИЧЕСТВА РЕСПУБЛИКИ БЕЛАРУСЬ
}

\author{
В. В. Подкопаев \\ начальник управления международного сотрудничества \\ аппарата Наџиональной академии наук Беларуси, \\ кандидат политических наук, доцент
}

УДК 001.32(476)

Расширение экспортно ориентированного научно-технического сотрудничества является одним из важнейших направлений внешней политики Республики Беларусь, и Национальная академия наук Беларуси как высшая государственная научная организация не может быть в стороне от этого процесса.

Договоренности, заключаемые Национальной академией наук Беларуси с зарубежными партнерами, призваны сформировать надежную правовую основу для обеспечения реализации совместных научных и научно-технических программ и проектов, что в свою очередь направлено на расширение объемов коммерциализации наукоемкой продукции на внешних рынках. Рассмотрим международную деятельность НАН Беларуси в разрезе политико-географических регионов с выделением наиболее перспективных направлений сотрудничества.

\section{СHГ}

Со всеми государствами СНГ Республика Беларусь имеет рамочные межправительственные соглашения о сотрудничестве в области науки и технологий. Развитие научно-технического сотрудничества с организациями Российской Федерации представляет одно из важнейших направлений внешней деятельности НАН Беларуси. Созданные механизмы научно-технического сотрудничества, в том числе в рамках Союзного государства Беларуси и России, позволяют эффективно выполнять совместные фундаментальные и прикладные исследования, инновационные проекты по приоритетным направлениям научно-технической деятельности России и Беларуси. Общий 
объем экспортных поступлений в 2014 г. по контрактам с российскими организациями составил 21,5 млн долларов.

Подписан ряд базовых договорных документов о сотрудничестве:

- Соглашение о сотрудничестве между Российской академией наук и Национальной академией наук Беларуси (2002);

- Договор о сотрудничестве между Академией наук Республики Беларусь и Академией наук Татарстана (1994);

- Договор о научном сотрудничестве между НАН Беларуси и Сибирским отделением РАН (2009);

- Договор о научном сотрудничестве между НАН Беларуси и Уральским отделением РАН (2005);

- Договор о научном сотрудничестве между НАН Беларуси и Санкт-Петербургским научным центром РАН (2002);

- Договор о научном сотрудничестве между НАН Беларуси и Академией наук Республики Башкортостан (2011).

Деятельность организаций НАН Беларуси и их российских партнеров направлена на выполнение совместных научных программ и проектов, создание структур и проработку других механизмов для коммерциализации результатов совместных научных исследований, организацию и проведение совместных научных мероприятий в передовых областях науки.

Информационную и организационную поддержку реализации совместных планов оказывает созданный в 2004 г. Межакадемический совет по проблемам развития Союзного государства, который работает в тесном контакте с Постоянным комитетом Союзного государства Беларуси и России, федеральными органами исполнительной власти России, госорганами Беларуси.

Большой вклад в расширение кооперации вносит реализация научно-технических программ в рамках Союзного государства Беларуси и России. Имея за плечами солидный багаж совместных научных разработок по итогам выполнения совместных программ в области информационных технологий, использования космоса, биотехнологий, нанотехнологий, разработок для АПК и др., государства планируют и далее развивать механизм решения в рамках программ Союзного государства комплексных проблем для инновационного развития экономики. Так, в 2011-2015 гг. НАН Беларуси реализовы- 
вала 4 программы Союзного государства, в ближайшей перспективе НАН Беларуси запланирована подготовка 11 новых союзных программ.

Большую роль в процессе развития белорусско-российского научно-технического сотрудничества играют совместные конкурсы научных проектов, организуемые фондами фундаментальных исследований. Находящийся в структуре НАН Беларуси Белорусский республиканский фонд фундаментальных исследований совместно с Российским фондом фундаментальных исследований (РФФИ) и Российским гуманитарным научным фондом (РГНФ) обеспечили, начиная с 1999 г., успешное проведение 9 совместных конкурсов с РФФИ и 17 с РГНФ.

Организации НАН Беларуси и их российские партнеры все активнее проводят работу по созданию совместных научных лабораторий и научно-производственных центров. Так, функционируют Научно-исследовательский центр нефте- и лесохимических технологий (на базе Института химии новых материалов НАН Беларуси и Института катализа им. Г. К. Борескова Сибирского отделения РАН), Российскобелорусская лаборатория электромагнитных и ионизирующих излучений (на базе Института радиобиологии НАН Беларуси и Института биохимической физики им. Н. М. Эмануэля РАН), Российскобелорусская лаборатория инновационных биоинженерных технологий (на базе Института экспериментальной ботаники им. В. Ф. Купревича НАН Беларуси и Института биофизики Сибирского отделения РАН), Российско-белорусская лаборатория системной биологии (на базе Института генетики и цитологии НАН Беларуси и Института цитологии и генетики Сибирского отделения РАН).

В декабре 2013 г. подписано Соглашение о создании Совместного центра науки и инновационной деятельности Сибирского отделения РАН и НАН Беларуси, в 2014 г. подписан Протокол о намерениях создания белорусско-российского центра коллективного пользования в области лазеров и лазерной техники.

В июне 2015 г. состоялось III совместное заседание президиумов РАН и НАН Беларуси, по итогам которого был утвержден План сотрудничества между РАН и НАН Беларуси на 2016-2020 гг.

С 2012 г. действует Соглашение о сотрудничестве между НАН Беларуси и АО «Национальный научно-технологический холдинг 
“Парасат”» Республики Казахстан. В апреле 2013 г. подписано Соглашение о сотрудничестве между АО «Фонд науки» Республики Казахстан и Белорусским республиканским фондом фундаментальных исследований (БРФФИ).

Белорусской и казахстанской сторонами создана совместная рабочая группа по проработке вопросов сотрудничества в космической сфере. Определен состав рабочей группы, первое заседание состоялось в марте 2015 г. в г. Астана. Ответственной казахстанской организацией определен Аэрокосмический комитет Министерства по инвестициям и развитию Республики Казахстан, ответственной белорусской организацией является Национальная академия наук Беларуси. По итогам обсуждения подготовленных сторонами презентаций и предложений совместная рабочая группа определила в качестве целесообразных для сотрудничества следующие направления:

1) дистанционное зондирование Земли и научные космические исследования;

2) космическая связь;

3) совместные инновационные исследования в области разработки и производства беспилотных авиационных летальных аппаратов, в том числе атмосферных спутников.

В ходе работ по расширению присутствия ОАО «НПО Центр» на рынке Республики Казахстан заключено дилерское соглашение с ТОО «Трансферт» (г. Астана). В дальнейшем по мере расширения продаж оборудования на базе этого предприятия планируется создать центр сервисного обслуживания, обеспеченный запасными частями и производственными мощностями для изготовления запасных частей и крупноузловой сборки.

В мае 2013 г. подписан Меморандум о сотрудничестве между AO «Национальный научно-технологический холдинг "Парасат", ЗАО «Голографическая индустрия» и ООО «Магия света», направленный на создание совместного казахстанско-белорусского предприятия в области защитной голографии «Голография Kazakh-Bel» на территории Республики Казахстан.

В сентябре 2013 г. подписано Соглашение о сотрудничестве и совместной деятельности в области исследований, разработки и производства светодиодной техники. С казахстанской стороны соглашение подписано компаниями TOO «ETS Engineering» и Специальной экономической зоной «Парк инновационных технологий “Алатау”», с 
белорусской - Центром светодиодных и оптоэлектронных технологий НАН Беларуси.

РУП «НПЦ НАН Беларуси по механизации сельского хозяйства» заключило с казахстанской стороной следующие рамочные договоры:

- с АО «Национальный инновационный фонд» - по сотрудничеству в области трансферта технологий и их адаптации к условиям применения, организации производства конкурентоспособной машиностроительной продукции, включающей проведение совместных научно-исследовательских и опытно-конструкторских работ, разработку конструкторско-технологической документации, организацию на территории Республики Казахстан совместного производства сельхозмашин, обучение и повышение квалификации научных работников;

- с ТОО «КазАгроСервис ПВ» - на реализацию современной сельскохозяйственной техники и животноводческого оборудования РУП «НПЦ НАН Беларуси по механизации сельского хозяйства» на территории Республики Казахстан и ее сервисного обслуживания;

- с ТОО «Конструкторское бюро сельскохозяйственного машиностроения» - по сотрудничеству в сфере науки и техники, реализации проектов в области механизации растениеводства и животноводства, переработки и хранения продукции.

«Научно-практический центр НАН Беларуси по земледелию» проводит совместную научно-исследовательскую работу согласно договору о деловом и творческом сотрудничестве с Институтом биологии и биотехнологии РГП НЦБ Министерства образования Республики Казахстан по производству сортов озимого и ярового рапса и проведению экологического сортоиспытания.

Государственное научное учреждение «Физико-технический институт Национальной академии наук Беларуси» приняло участие в III Международной выставке вооружения и военно-технического имущества «KADEX-2014» (май 2014 г., г. Астана, Республика Казахстан), на которой были представлены беспилотные авиационные комплексы.

Во время проведения выставки подписан Меморандум о сотрудничестве с ТОО «Научно-исследовательский институт "Казахстан инжиниринг”, головной компанией по разработке и производству беспилотных авиационных комплексов в Казахстане, направленный 
на поставку многофункциональных БАК и организацию их сборочного производства на территории Казахстана.

В 2014 г. организации НАН Беларуси выполняли работы по заказу казахстанских партнеров на общую сумму 450 тыс. долларов.

Научно-техническое сотрудничество НАН Беларуси с организациями Украины осуществляется на основе рамочного Договора о научном сотрудничестве с Национальной академией наук Украины (2002), приложением к которому является Протокол о безвалютном эквивалентном обмене учеными (общая квота - 100 человеко-дней), с Национальной академией аграрных наук Украины (2014), с Киевской государственной Академией водного транспорта им. гетмана Петра Конашевича-Сагайдачного (2014). Общий объем экспортных поступлений в 2014 г. по контрактам с украинскими организациями составил 1,5 млн долларов.

С 2009 г. проведено 3 конкурса совместных проектов в рамках Договора о сотрудничестве между БРФФИ и Государственным фондом фундаментальных исследований Украины.

Действует рамочный Договор о научном сотрудничестве между Национальной академией наук Беларуси и Национальной академией наук Республики Армения (2010).

В октябре 2013 г. Национальная академия наук Беларуси, Государственный комитет по науке и технологиям Республики Беларусь и Национальная академия наук Республики Армения, Государственный комитет по науке Министерства образования и науки Республики Армения подписали Договор о создании Международного научнопрактического центра для решения экологических, научно-технических проблем, изучения культурно-исторического наследия и экосистем пресноводных водоемов (озеро Севан, озеро Нарочь и др.), представляющих национальное достояние этих стран.

Работа центра позволит координировать реализацию совместных научных исследований в передовых областях науки, обеспечит эффективное совместное использование опыта ведущих ученых двух стран.

Белорусский республиканский фонд фундаментальных исследований в ноябре 2010 г. заключил Договор о научно-техническом сотрудничестве с Государственным комитетом по науке Министерства образования и науки Армении. В соответствии с договором проведе199 
но два конкурса совместных проектов, реализованных организациями Беларуси и Армении.

Действует рамочный Договор о научном сотрудничестве между Национальной академией наук Беларуси и Академией наук Молдовы (2003), составной частью которого является Протокол о безвалютном эквивалентном обмене учеными между НАН Беларуси и Академией наук Молдовы, регламентирующий объем безвалютного эквивалентного обмена (общий объем 30 человеко-дней), порядок командирования научных сотрудников и условия финансирования.

В соответствии с Меморандумом по итогам визита руководства Академии наук Молдовы в Национальную академию наук Беларуси в феврале 2003 г. стороны определили в качестве приоритетных направлений сотрудничества исследования в таких областях и направлениях, как новые материалы, сельскохозяйственные технологии, энергетика, оптика, генетика, информационные технологии, экономика и гуманитарные науки.

В 2007 г. Белорусский республиканский фонд фундаментальных исследований заключил соглашение с Академией наук Молдовы о проведении регулярных совместных конкурсов научных исследований по направлениям, согласованным обеими сторонами. К июню 2015 г. проведено 4 совместных конкурса. Тематика конкурсов включает биомедицину и фармацевтику, исследование, переработку и использование водных ресурсов, защиту природных ресурсов, машиностроение, новые материалы, нанотехнологии и др. направления.

В январе 2009 г. подписан Протокол к Договору о научном сотрудничестве между НАН Беларуси и АН Молдовы, цель которого развитие сотрудничества в области селекции и генетики, разработка новых перспективных гибридов семян кукурузы и новых технологий по их возделыванию, а также использование научного и производственного потенциала обеих стран для обеспечения семенами кукурузы сельского хозяйства Беларуси.

В ходе визита председателя Президиума НАН Беларуси в Грузию в составе государственной делегации (апрель 2015 г.) подписаны рамочные договоры о научно-техническом сотрудничестве НАН Беларуси с Национальной академией наук Грузии и Академией сельскохозяйственных наук Грузии. 
В 2014 г. республиканское научное дочернее унитарное предприятие «Институт мелиорации» заключило два соглашения о научном сотрудничестве с грузинскими партнерами: с Институтом водного хозяйства Грузинского технического университета и непредпринимательским (некоммерческим) юридическим лицом «Экоцентр охраны окружающей среды».

В 2015 г. подписан Договор о научно-техническом сотрудничестве между научно-исследовательским центром сельского хозяйства Министерства сельского хозяйства Грузии и Научно-практическим центром Национальной академии наук Беларуси по картофелеводству и плодоовощеводству.

В апреле 2014 г. между Национальной академией наук Беларуси и Академией наук Республики Таджикистан заключен Договор о сотрудничестве, цель которого - организация совместных программ в области подготовки кадров высшей научной квалификации, а также укрепление всесторонних связей между организациями обеих академий наук.

Три конкурса совместных исследовательских проектов, реалиизуемых учеными Беларуси и Азербайджана, проведено с 2007 по 2011 г. на основе подписанного Соглашения о сотрудничестве между Национальной академией наук Беларуси, Белорусским республиканским фондом фундаментальных исследований и Национальной академией наук Азербайджана.

Дальнейшая двусторонняя поддержка совместных проектов осуществлялась на основе Соглашения о сотрудничестве между НАН Беларуси, БРФФИ и Фондом развития науки при Президенте Азербайджанской Республики (ФРНА). В рамках данного соглашения проведено 2 конкурса совместных проектов.

В августе 2012 г. в Национальной академии наук Беларуси состоялось I заседание белорусско-азербайджанской рабочей группы по совместным инновационным проектам.

Были рассмотрены перспективные проектные предложения по линии министерств и ведомств, представители которых входят в состав рабочей группы, и принято решение (подписан протокол по итогам заседания) о двусторонней проработке механизмов их реализации. 
В сентябре 2013 г. в г. Баку состоялось II заседание рабочей группы по совместным инновационным проектам, в котором приняли участие представители Национальной академии наук Беларуси, Министерства промышленности, Министерства здравоохранения, Министерства образования Республики Беларусь.

По итогам заседания подписан протокол, которым утверждены перечни совместных инициатив по 3 комплексным направлениям:

- реализация совместных научных исследований;

- реализация совместных инновационных проектов в интересах экономики Азербайджанской Республики и Республики Беларусь;

- организация совместных производств инновационной продукции.

В 2012 г. подписан Договор о научном сотрудничестве между НАН Беларуси и Академией наук Туркменистана. В ходе визита государственной делегации Беларуси в Туркменистан в ноябре 2013 г. подписана подготовленная Академиями наук Беларуси и Туркменистана Программа сотрудничества в области науки и технологий (включает 19 проектов).

По итогам I заседания Межправительственной белорусско-туркменской комиссии по сотрудничеству в области науки и технологий (ноябрь 2013 г., г. Минск) было принято решение на первом этапе реализации Программы сотрудничества между Национальной академией наук Беларуси и Академией наук Туркменистана в области науки и технологий из 19 пунктов выбрать 3-4 наиболее актуальных и готовых к выполнению совместных проекта.

В качестве приоритетных проектов были определены взаимодействие ботанических садов Беларуси и Туркменистана в целях сохранения биоразнообразия, создание опытных производств малотоннажной химической продукции путем переработки углеводородного сырья, разработка ДНК-паспортизации и маркер-сопутствующей селекции в растениеводстве, совместные разработка и производство беспилотных авиационных комплексов.

В ходе официального визита президента Туркменистана Г. М. Бердымухамедова в Беларусь (октябрь 2014 г.) подписано Соглашение о научном сотрудничестве между государственным научным учреждением «Институт истории Национальной академии наук Беларуси» и Институтом истории Академии наук Туркменистана. 


\section{Европейский союз}

По состоянию на июнь 2015 г. Национальной академией наук Беларуси подписано 28 соглашений о сотрудничестве с академиями наук и другими национальными научными центрами из 21 государства ЕС (Австрия, Бельгия, Болгария, Венгрия, Великобритания, Германия, Испания, Италия, Латвия, Литва, Нидерланды, Польша, Португалия, Румыния, Словакия, Словения, Финляндия, Франция, Чехия, Швеция, Эстония).

Общий объем экспортных поступлений из государств ЕС в организации НАН Беларуси в 2014 г. составил более 5,4 млн долларов.

В 2014 г. были подписаны Протокол к Соглашению о научнотехническом сотрудничестве между Польской академией наук и НАН Беларуси на 2014-2016 гг., регламентирующий объем безвалютного эквивалентного обмена (общий объем 150 человеко-дней), порядок командирования научных сотрудников и условия финансирования, а также Протокол о намерениях между Институтом Лауэ-Ланжевена (Франция), закрепляющий договоренность определить приоритетные направления и механизмы совместной деятельности.

В 2015 г. в ходе визита делегации Национальной академии наук Беларуси в Португалию подписан Меморандум о намерениях в области научного сотрудничества между Лиссабонской академией наук и Национальной академией наук Беларуси, на основании которого стороны договорились взаимодействовать посредством совместных семинаров, встреч, симпозиумов и учебных программ для развития научных исследований и связанных с ними мероприятий, представляющих взаимный интерес.

В апреле 2015 г. делегация НАН Беларуси участвовала в Генеральной ассамблее Европейской ассоциации академий наук (ALLEA) в г. Лиссабоне. ALLEA - федерация 58 академий наук и искусств из 40 европейских стран (в том числе Беларуси) - самое влиятельное объединение научных организаций на европейском пространстве. Ассоциация преследует цели обмена информацией и опытом между академиями наук, содействия установлению и поддержанию высоких стандартов научной деятельности и экспертизы. Основные направления работы ALLEA - это организация мероприятий для создания общеевропейского исследовательского пространства, защиты интеллектуальной собственности, освещения проблем и тенденций развития 
науки в СМИ, вопросов научной этики, а также создание механизмов управления в научно-техническом секторе.

В рамках мероприятия представителями ряда академий наук (Эстонской, Литовской, Чешской, Британской, Словацкой, Польской, Австрийской) достигнута договоренность об инициировании очередного этапа формирования двусторонних научных групп по реализации совместных проектов, в том числе в рамках программы ЕС «Горизонт 2020». С представителями еще одной группы академий наук (Латвийской, Норвежской, Нидерландской) обсуждены организационные вопросы реализации новых мероприятий. Одним из результатов заседания стало решение о проведения заседания Совета ALLEA (руководящий орган Ассоциации) в г. Минске в июне 2016 г.

\section{Восточная Азия}

Национальная академия наук Беларуси придает особое значение сотрудничеству с Китайской Народной Республикой - страной с огромным научным и экономическим потенциалом, с которой у Республики Беларусь сложились прочные стратегические отношения во всех сферах, в том числе и научно-технической.

20 лет назад подписанием Соглашения о сотрудничестве в области науки и технологий между правительствами Беларуси и КНР были заложены основы двустороннего сотрудничества. Для координации действий по достижению целей соглашения создана Межправительственная белорусско-китайская комиссия по сотрудничеству в области науки и технологий, изучающая все вопросы реализации соглашения, возможности расширения и диверсификации экономического, научного и технического сотрудничества между двумя странами, определяющая программы и проекты для этих целей, а также предложения по дальнейшему развитию белорусско-китайского сотрудничества. В мае 2012 г. создана Межправительственная белорусско-китайская комиссия по сотрудничеству в области высоких технологий, основной задачей которой является координация белорусскокитайского научно-технического сотрудничества в приоритетных направлениях в области высоких технологий: микроэлектроника, информационные технологии, оптические и лазерные технологии, машиностроение, биотехнологии, новые материалы, технологии для нужд химической промышленности, сельскохозяйственная техника и технологии, новые виды энергетики. 
По мере увеличения плодотворных контактов между научными учреждениями КНР и Беларуси и в целях координации развития научно-технического взаимодействия НАН Беларуси подписала ряд документов, регулирующих вопросы сотрудничества и обозначивших научные направления, представляющие взаимный интерес:

- с Академией наук Китая от 5 декабря 2005 г.;

- с Народным правительством г. Харбина от 20 апреля 2009 г.;

- с Академией наук провинции Шаньдун от 20 июня 2000 г.;

- с Академией наук провинции Хэйлунцзян от 13 марта 2001 г.;

- с Северо-восточным центром Китая по сельскохозяйственным науке и технологиям от 15 июня 2005 г.;

- с Юнаньской академией сельскохозяйственных наук от 30 июля 2006 г.

- с Академией наук провинции Хэйлунцзян от 29 ноября 2010 г.

- с Академией сельскохозяйственных наук провинции Цзянсу от 6 октября 2014 г.

- с Правительством г. Линьи от 6 апреля 2015 г.;

- с Китайской академией общественных наук от 10 мая 2015 г.

Сегодня НАН Беларуси на основе данных договорных документов выполняет проекты с китайскими партнерами на общую сумму более 4 млн долларов. Однако потенциал сотрудничества ученых обеих стран далеко не исчерпан. НАН Беларуси предлагает китайским партнерам перспективные разработки в области оптоэлектронных и лазерных технологий, в сфере разработки и использования беспилотной авиационной техники, дистанционного зондирования Земли с помощью спутников, в сфере мембранных технологий, а также разработки в области нанотехнологий в частности материалы для суперконденсаторов на базе графена, технику для наноконтроля в сфере материаловедения, электроники и клеточных технологий. В связи с этим Беларусь заинтересована в более активном участии в реализации Государственного плана КНР средне- и долгосрочного развития в области науки и техники на 2006-2020 гг.

Национальной академией наук Беларуси предпринимаются действия по развитию сотрудничества с партнерами из Республики Корея. Заключены следующие договоренности о взаимодействии в научно-технической области:

- Договор о научном сотрудничестве с Корейским институтом промышленных технологий Республики Корея (КITECH) (2000); 
- Меморандум о сотрудничестве с Министерством торговли, промышленности и энергетики Республики Корея (2004);

- Меморандум о взаимопонимании между НАН Беларуси и компанией POSCO (2007);

- Меморандум о взаимопонимании с компанией «Бекс Инжиниринг ЛТД» (2008);

- Меморандум о сотрудничестве с Донггукским университетом (2013);

- Меморандум о сотрудничестве с Исследовательским институтом промышленных наук и технологий (RIST) (2014).

Объем экспорта продукции НАН Беларуси в Корею в 2014 г. составил 250 тыс. долларов.

Важное значение в части наращивания экспорта имеет развитие сотрудничества с Монголией. В 2014-2015 гг. в рамках конкурса Белорусского республиканского фонда фундаментальных исследований и Научно-технологического фонда Монголии было реализовано 3 совместных проекта.

\section{Южная Азия}

Национальная академия наук Беларуси активно развивает сотрудничество с партнерами из Республики Индия.

Объем экспортных поступлений НАН Беларуси по контрактам с индийскими партнерами в 2014 г. составил 270 тыс. долларов. Заключены следующие договоренности о взаимодействии в научнотехнической области:

- Договор о научном сотрудничестве с Департаментом биотехнологий Министерства науки и технологий Правительства Индии (DBT) (2000);

- Договор о научном сотрудничестве с Индийской национальной академией наук (INSA) (2003);

- ряд договоров с Организацией оборонных исследований и разработок (DRDO).

Приоритетными направлениями сотрудничества с индийскими партнерами по линии НАН Беларуси являются новые материалы, лазерные технологии и технологии для агропромышленного комплекса. Ведутся переговоры с Министерством науки и технологий Индии по инициированию совместной программы в области дистанционного зондирования Земли. 
Функционирует Межправительственная белорусско-индийская комиссия по сотрудничеству в области науки и техники на основе Соглашения о сотрудничестве в области науки и техники между правительствами Республики Беларусь и Республики Индия, основной задачей которой является координация белорусско-индийского научно-технического сотрудничества в приоритетных направлениях.

Новым направлением развития научно-технического сотрудничества для НАН Беларуси является взаимодействие с партнерами из Исламской Республики Пакистан.

В рамках визита в Национальную академию наук Беларуси научно-образовательной делегации данной страны в составе главного ученого секретаря Пакистанской академии наук 3. К. Шинвари и исполнительного директора Комитета высшего образования Пакистана М. А. Кунди в марте 2015 г. (это был первый визит руководителей пакистанского научного сообщества в НАН Беларуси за длительный период) подписан Меморандум о намерениях в области научного сотрудничества между Национальной академией наук Беларуси и Пакистанской академией наук.

Стороны обязуются предпринимать меры для совместной разработки и реализации научно-исследовательских проектов, совместной организации и проведения семинаров, встреч, симпозиумов и учебных программ, для развития научных исследований и связанных с ними мероприятий, представляющих взаимный интерес.

В мае 2015 г. в НАН Беларуси состоялся визит министра по делам шахт и минералов провинции Пенджаб Ш. Али, по итогам которого подписан Протокол, закрепивший в качестве приоритетов сотрудничества НАН Беларуси с партнерами из провинции Пенджаб следующие направления:

- производство продукции для горнодобывающей и строительных отраслей;

- оценка состояния и использование природных ресурсов;

- разработка и поставка сельскохозяйственной техники;

- разработка технологий функционального питания;

- производство и использование беспилотных летательных аппаратов для горнодобывающей промышленности;

- дистанционное зондирование Земли для горнодобывающей промышленности. 
В мае 2015 г. состоялся визит председателя Президиума НАН Беларуси В. Г. Гусакова в Исламскую Республику Пакистан в составе государственной делегации Республики Беларусь, в ходе которого подписан Договор о научно-техническом сотрудничестве между Национальной академией наук Беларуси и Пакистанской академией наук, взаимодействие сторон в рамках которого будет осуществляться путем:

- реализации совместных исследовательских и инновационных проектов;

- организации совместных программ подготовки научных кадров высшей квалификации;

- подготовки совместных научных и информационно-аналитических изданий;

- совместного проведения конференций, семинаров и совещаний по вопросам, представляющим взаимный интерес;

- совместной организации либо взаимного участия в научных мероприятиях сторон по широкому спектру научных направлений (в соответствии с приложением в момент подписания закреплено 4 приоритетных направления (проведение совместных испытаний яровых зерновых культур на территории Исламской Республики Пакистан; поставка сельскохозяйственной техники в Исламскую Республику Пакистан; разработка технологий обработки, хранения и переработки сельскохозяйственной продукции, производства продуктов функционального, специализированного и общественного питания; совершенствование национальной системы биобезопасности в сфере генетически модифицированных организмов), перечень которых может дополняться по согласованию сторон);

- обмена научной и другой информацией.

\section{Юго-Восточная Азия}

Национальная академия наук Беларуси активно развивает сотрудничество с партнерами из Социалистической Республики Вьетнам. Заключены следующие договоренности о взаимодействии в научно-технической области:

- Договор о научном сотрудничестве с Ханойским технологическим университетом (2007);

- Договор о научном сотрудничестве с Вьетнамской академией наук и технологий (ВАНТ) (2008); 
- Меморандум о сотрудничестве с Хюэсским университетом (2011);

- Меморандум о сотрудничестве с Центром военных наук и технологий Министерства обороны Вьетнама (2014).

Перспективными направлениями взаимодействия на кратко- и среднесрочную перспективы определены проекты в сфере переработки минерального сырья, получения новых строительных материалов, дробления, измельчения и обогащения рудных и нерудных материалов; разработки и совместного производства беспилотных авиационных комплексов; энергетики; лазерной физики; биотехнологий.

Новым рынком для проработки вопросов развития экспортно ориентированного сотрудничества НАН Беларуси является Индонезия. В 2012 г. подписан Договор о сотрудничестве между НАН Беларуси и Технологическим университетом г. Бандунга, направленный на организацию совместных программ по обучению аспирантов и докторантов Республики Индонезия в институтах НАН Беларуси.

На основе подписанной в декабре 2013 г. Программы сотрудничества между Индонезийским институтом наук и НАН Беларуси в сфере науки и технологий с IV квартала 2013 г. по линии Белорусского республиканского фонда фундаментальных исследований выполняется 3 совместных белорусско-индонезийских проекта.

В июле 2014 г. делегация Национальной академии наук Беларуси посетила с рабочим визитом Индонезийский исследовательский институт каучука в г. Богор.

В рамках визита подписан Договор о сотрудничестве между данным институтом и Институтом экспериментальной ботаники им. В. Ф. Купревича, определены перспективные направления сотрудничества в области технологий получения биологически активных веществ из продуктов переработки латекса гевеи бразильской, использования удобрений на основе наночастиц микроэлементов, белорусской стороне для проведения пилотных исследований передан образец технологического латекса.

Договорную базу по развитию сотрудничества НАН Беларуси с государствами Юго-Восточной Азии в 2014 г. пополнили Меморандум о взаимопонимании между НАН Беларуси и Институтом технологий Камбоджи и Протокол о намерениях между НАН Беларуси и Министерством по науке и технологиям Лаоса. 


\section{Ближний Восток}

Активная совместная проработка вопросов развития сотрудничества Национальной академии наук Беларуси с организациями Исламской Республики Иран началась с середины 2000-х гг., подписаны следующие договорные документы:

- Договор о сотрудничестве с Исламским университетом «Азад» (2009);

- Соглашение о сотрудничестве с Технологическим университетом «Малек-Аштар» (2011);

- Меморандум о взаимопонимании с Инициативным советом по нанотехнологиям Ирана (INIC) (2012); (2012);

- Соглашение о сотрудничестве с Университетом Ш. Бехешти

- Соглашение о научно-техническом сотрудничестве с Технологическим университетом им. К. Н. Туси (2014).

По договору с Исламским университетом «Азад» в 20142015 гг. успешно закончили обучение в аспирантуре научных организаций НАН Беларуси 17 иранских граждан.

В мае 2015 г. в г. Минске была проведена вторая Международная белорусско-иранской конференция «Современное применение нанотехнологий», организаторами которой выступили Национальная академия наук Беларуси (ГО «НПЦ НАН Беларуси по материаловедению») и университет Тарбиата Модарреса (Исламская Республика Иран), в ходе которой подписаны следующие документы:

1) Меморандум о намерениях по научно-техническому сотрудничеству между Иранским нанотехнологическим обществом и Белорусской ассоциацией нанотехнологий;

2) Соглашение о научном сотрудничестве в сфере подготовки научных кадров между Университетом Тарбиата Модарреса и ГУО «Институт подготовки научных кадров НАН Беларуси»;

3) Соглашение о научном сотрудничестве в сфере подготовки научных кадров между Технологическим университетом Шариф и НАН Беларуси.

Сотрудничество организаций НАН Беларуси с научными учреждениями Королевства Саудовская Аравия осуществляется на основе Соглашения о сотрудничестве между НАН Беларуси и Научнотехнологическим центром им. Короля Абдулазиза (KACST), заклю- 
ченного 15 декабря 2007 г. По состоянию на июнь 2015 г. с партнерами из Саудовской Аравии на контрактной основе реализуется более 20 совместных проектов на общую сумму более 16 млн долларов. В мае 2015 г. в г. Эр-Рияд состоялось первое заседание Совместного комитета по сотрудничеству между правительствами Республики Беларусь и Королевства Саудовская Аравия, в котором приняла участие и делегация НАН Беларуси. В рамках заседания состоялся ряд встреч и переговоров с руководством Научного центра им. Короля Абдуллы по ядерной и возобновляемой энергии и Научно-технологического центра им. Короля Абдулазиза. По итогам определены перспективные направления взаимовыгодного сотрудничества между научными организациями двух стран: новые материалы, энергетика (включая ядерную), ядерная физика, физика элементарных частиц и др.

В соответствии с Соглашением о сотрудничестве в области организации образовательных программ между Национальной академией наук Беларуси и Международной сирийской академией (Сирийская Арабская Республика), подписанным в декабре 2014 г., стороны договорились предоставлять обучающие программы на базе НАН Беларуси для подготовки магистров и докторов наук для Сирийской Арабской Республики и других стран в различных областях научной деятельности; организовывать краткосрочные, среднесрочные и долгосрочные программы повышения квалификации по широкому спектру направлений; проводить семинары для организаторов и участников образовательных программ. По состоянию на июнь 2015 г. (за полгода после подписания соглашения) для обучения в организациях НАН Беларуси привлечено более 20 граждан государств Ближнего Востока.

\section{Латинская Америка}

Научно-техническое сотрудничество Беларуси и Венесуэлы основывается на Соглашении между Правительством Республики Беларусь и Правительством Боливарианской Республики Венесуэла о сотрудничестве в области науки и технологий от 24 июля 2006 г.

В соответствии с указанным Соглашением создана Межправительственная белорусско-венесуэльская комиссия по сотрудничеству в области науки и технологий. Посредством ее работы обеспечивается проведение консультаций по вопросам государственной научнотехнической политики стран - участниц соглашения и экономико- 
правового регулирования в этой сфере, а также согласование приоритетных направлений двустороннего взаимодействия. Комиссия уполномочена также рассматривать и утверждать совместные проекты для последующей реализации. На первом заседании Межправкомиссии в 2007 г. утверждены приоритетные направления белорусско-венесуэльского научно-технического сотрудничества:

сельское хозяйство (машиностроение, биотехнологии в животноводстве и растениеводстве, биоудобрения, здоровье животных, биобезопасность, использование и плодородие почв);

окружающая среда (радиоактивные загрязнения, геоинформационные системы, парниковый эффект);

электроника (радиоэлектроника, микроэлектроника);

телекоммуникации (сенсорика, микросенсорика, дистанционное зондирование Земли), энергетика.

В 2012 г. подписана Исполнительная программа научно-технического сотрудничества между Республикой Беларусь и Боливарианской Республикой Венесуэла на 2012-2015 гг., которой утверждены в том числе приоритетные для обеих сторон направления сотрудничества:

окружающая среда и развитие;

здоровье общества;

продовольственная безопасность;

информационные и коммуникационные технологии;

нефть, газ и источники альтернативной энергии;

оптический инструментарий.

В конце 2013 г. в качестве очередного шага к расширению взаимодействия сторонами был подготовлен проект программы «Дорожная карта двустороннего сотрудничества Республики Беларусь и Боливарианской Республики Венесуэла на среднесрочную и долгосрочную перспективы», однако вследствие ряда тенденций в мировой экономике, негативно повлиявших на экономические процессы как в государствах ЕАЭС, так и в Венесуэле, процесс согласования программы и проработки механизмов реализации входящих в нее проектов был приостановлен с тем, чтобы вернуться к рассмотрению данного вопроса в возможно короткие сроки.

Научно-техническое сотрудничество Беларуси и Эквадора основывается на Соглашении между Правительством Республики Бела- 
русь и Правительством Республики Эквадор о сотрудничестве в области высшего образования, науки, технологий и инноваций от 28 июня 2012 г.

В соответствии с Соглашением создана Смешанная белорусскоэквадорская комиссия, которая выполняет функции определения приоритетов сотрудничества в области высшего образования, науки, технологий и инноваций; разработки планов реализации каждой достигнутой договоренности; формирования благоприятных условий для осуществления сотрудничества; анализа и выработки рекомендаций для оптимизации взаимодействия в рамках Соглашения.

В 2013 г. в рамках заседания совместной белорусско-эквадорской рабочей группы по науке, технологиям и образованию белорусская и эквадорская стороны определили области для дальнейшего взаимодействия, в частности дистанционное зондирование Земли с использованием возможностей белорусского космического аппарата; беспилотные летательные аппараты для охраны границ, анализа природных ресурсов, диагностирования чрезвычайных ситуаций; фармацевтические препараты белорусского производства.

Стороны запланировали предпринять усилия, чтобы в долгосрочной перспективе для работы по каждому из этих направлений в Эквадоре были созданы совместные лаборатории с участием организаций НАН Беларуси.

Научно-техническое сотрудничество Беларуси и Кубы основывается на Соглашении между Правительством Республики Беларусь и Правительством Республики Куба о сотрудничестве в области науки и технологий от 26 июня 2012 г.

По линии НАН Беларуси с Республикой Куба взаимодействие осуществлялось на основе Соглашения о научном сотрудничестве между Академией наук Беларуси и Академией наук Кубы от 16 сентября 1993 г. Соглашение определяет основные направления взаимодействия (гидробиология, рациональное использование природных ресурсов и биоразнообразие, биотехнологии, научное приборостроение и др.), а также условия безвалютного эквивалентного обмена сотрудниками двух академий.

Действует также подписанный в 2004 г. Договор о сотрудничестве между Центральным ботаническим садом НАН Беларуси и Ботаническим садом Сьенфуэгоса Министерства науки, технологии и охраны окружающей среды Республики Куба, а также подписанное в 
2009 г. Соглашение о намерениях между кубинским Центром молекулярной иммунологии и Национальной академией наук Беларуси, предусматривающее возможность проведения совместных исследований в области молекулярной иммунологии, включая фундаментальные исследования, разработку, производство и регистрацию иммунобиотехнологических продуктов для лечения и профилактики иммунозависимых заболеваний, доклинические и клинические испытания.

В июне 2011 г. по итогам визита в Беларусь директора Центра биомолекулярной химии Республики Куба В. Вереса подписан протокол между указанным институтом и представителями руководства НАН Беларуси, Минздрава и концерна «Белбиофарм», закрепивший договоренности:

- о рассмотрении вопроса целесообразности создания совместного производства лекарственных средств на основе биотехнологий с последующим трансфером таких технологий в Республику Беларусь кубинской стороной;

- о проработке вопроса организации в Республике Куба кабинетов фотодинамической терапии с передачей лазерной техники производства Республики Беларусь;

- об обмене опытом в части разработки и освоения биотехнологической продукции для медицинских целей.

Межправительственное соглашение между Республикой Беларусь и Боливией, направленное непосредственно на развитие двустороннего научно-технического сотрудничества, по состоянию на май 2015 г. еще готовится к подписанию. Поэтому заинтересованные организации двух стран, в том числе и НАН Беларуси, опираются при планировании совместных мероприятий на Соглашение между Правительством Республики Беларусь и Правительством Многонационального Государства Боливия о торгово-экономическом сотрудничестве от 4 сентября 2013 г.

В 2013 г. по итогам заседания белорусско-боливийской рабочей группы по науке, технологиям и образованию (орган при Межправкомиссии) оформлена договоренность предпринять активные действия по следующим направлениям:

- подготовка и реализация совместных белорусско-боливийских научно-технических, исследовательских и образовательных программ и проектов в интересах экономик двух государств; 
- организация совместных целевых программ по обучению аспирантов и докторантов Многонационального Государства Боливия в институтах НАН Беларуси;

- проработка вопроса создания совместных предприятий для внедрения результатов совместных проектов и контрактов;

- обмен информацией, организация и совместное участие в научно-технических и образовательных мероприятиях по согласованным тематическим направлениям;

- распространение рекламной и научно-технической информации о возможностях Республики Беларусь и Многонационального Государства Боливия в научно-технической и инновационной сферах.

Стороны определили в качестве приоритетных следующие области для совместных работ:

- дистанционное зондирование Земли;

- производство и использование беспилотных летательных аппаратов;

- разработка сельскохозяйственной техники;

- разработка технологий функционального питания;

- производство оборудования для горнодобывающей и строительной отраслей;

- оценка состояния и использования природных ресурсов.

В развитие договоренностей, достигнутых в ходе отмеченного визита, НАН Беларуси подготовлен проект соглашения между НАН Беларуси, Государственным комитетом по науке и технологиям Республики Беларусь (далее - ГКНТ) и Министерством образования Боливии, подписание которого запланировано на очередное заседание Совместной белорусско-боливийской комиссии по торговому и экономическому сотрудничеству. Подготовлен и согласован проект соглашения о сотрудничестве между НАН Беларуси и НАН Боливии, подписание которого две академии наук также планируют приурочить к заседанию Совместной комиссии.

На основе анализа имеющейся инфраструктуры развития сотрудничества с участием НАН Беларуси с конкретными государствами можно выделить перспективные направления концентрации организационных и финансовых ресурсов для повышения эффективности сотрудничества с рассмотренными странами, а также для расширения сотрудничества в сфере науки и технологий с другими странами представленных регионов: 
расширение и активизация сотрудничества в рамках краткосрочных и среднесрочных научно-технических программ и проектов, направленных на использование их результатов в реальном секторе экономики;

осуществление на регулярной основе взаимных визитов специалистов с целью повышения эффективности согласования хода проектных работ и детального обсуждения областей и механизмов совместной коммерциализации полученных результатов;

регулярное проведение двусторонних и многосторонних научных мероприятий, кооперационных бирж в приоритетных областях научно-инновационного развития Беларуси и стран-партнеров;

расширение перечня конкретных направлений деятельности, курируемых функционирующими совместными межправительственными комиссиями по сотрудничеству в области науки, технологий и образования;

расширение программ подготовки научных кадров высшей квалификации на базе организаций НАН Беларуси в интересах партнерских государств;

создание совместных научных и инновационных подразделений (центров, лабораторий, предприятий), в том числе в рамках формируемых технопарковых зон в Беларуси и других странах.

\section{Национальная академия наук Беларуси в системе развития много- стороннего международного научно-технического сотрудничест- ва Республики Беларусь (Владимир Подкопаев)}

Приведена характеристика основных направлений развития международного научно-технического сотрудничества Национальной академии наук Беларуси в разрезе политико-географических регионов. Выделены договорная база и экспортная составляющая международного сотрудничества НАН Беларуси в области науки и инноваций, в том числе в контексте деятельности межправительственных комиссий по развитию научно-технического сотрудничества. Представлены перспективные направления концентрации организационных и финансовых ресурсов для повышения эффективности сотрудничества Республики Беларусь с конкретными странами, а также для выхода с использованием установившихся контактов на новые рынки наукоемкой продукции. 


\section{Ключевые слова}

Международное научно-техническое сотрудничество; Национальная академия наук Беларуси; экспорт наукоемкой продукции; договорные документы; перспективные направления взаимодействия; механизмы развития сотрудничества.

The National Academy of Sciences of Belarus in the system of development of multilateral international scientific and technical cooperation of the Republic of Belarus (Vladimir Podkopaev)

A description of the main directions of development of the international scientific and technological cooperation of the National Academy of Sciences of Belarus in the context of the political and geographical regions is given. Legal base and the export component of NASB international cooperation in science and innovation, including in the context of the intergovernmental commissions on the development of scientific and technical cooperation has been revealed. Perspective areas of concentration of the organizational and financial resources to improve the efficiency of cooperation between the Republic of Belarus and specific countries as well as the access to new markets of high technology products had been described.

\section{Key words}

The international scientific and technical cooperation; the National Academy of Sciences of Belarus; the export of high technology products; contract documents; perspective areas of interaction; mechanisms of cooperation development .

Статья поступила в мае 2015 г.

\section{Рецензенты:}

Решетников С. В. - доктор политических наук, профессор, заведующий кафедрой политологии Белорусского государственного университета;

Есин Р. О. - доктор политических наук, профессор кафедры международных отношений Академии управления при Президенте Республики Беларусь. 


\section{ПОЛИТИЧЕСКИЕ ОТНОШЕНИЯ МЕЖДУ КНР \\ И НЕКОТОРЫМИ ГОСУДАРСТВАМИ \\ ЛАТИНСКОЙ АМЕРИКИ}

\section{И. В. Резников}

аспирант кафедры международных отношений

факультета международных отношений БГУ

УДК $327(510: 7 / 8=134)$

Смещение основного вектора внешней политики Соединенных Штатов Америки в Азиатско-Тихоокеанский регион оказало непосредственное влияние на развитие региональной подсистемы международных отношений в Латинской Америке, которая на протяжении почти двухсот лет (точка отсчета - провозглашение Доктрины Монро в 1823 г.) была зоной безраздельной гегемонии США. Снижение уровня вовлеченности Вашингтона в политические процессы в этой части света создало предпосылки для активизации деятельности прочих ведущих субъектов международных отношений, прежде всего КНР, ЕС и России, по укреплению связей с латиноамериканскими государствами как в двустороннем формате, так и с задействованием механизмов региональных международных организаций. В то же время наращивание присутствия (в том числе военного) США вблизи китайской территории (Япония, Республика Корея, Филиппины), осуществляемое в соответствии с новой Стратегией национальной безопасности [29], вынуждает Пекин принимать адекватные ответные меры, важной составляющей которых является расширение взаимодействия по максимально возможному числу направлений со странами Западного полушария.

В целом вступившее в должность в марте 2013 г. руководство Китая во главе с председателем КНР Си Цзиньпином значительно расширило географию визитов, охватив почти все регионы мира. Уже в течение первых трех месяцев после назначения прошли двусторонние или многосторонние переговоры обновленной китайской политической элиты с руководителями более 50 стран. В рамках подобного многовекторного внешнеполитического курса весной 2013 г. состоялись визиты премьера Государственного совета КНР Ли Кэцяна в Индию, Пакистан, Германию и Швецию, а также председателя КНР 
Си Цзиньпина в Россию, страны Африки, Латинской Америки и США. При этом глава китайского государства за 13 месяцев (в июне 2013 г. и в июле 2014 г.) совершил два турне по латиноамериканским странам, что демонстрирует исключительную важность данного направления внешней политики Пекина [6].

Следует отметить, что инструментарий стратегии КНР в Латинской Америке чрезвычайно разнообразен и не ограничивается экономическим сотрудничеством. Одним из проявлений «мягкой силы» может служить ряд мероприятий, проводимых руководством Китая с целью повышения «моральной притягательности размеренных шагов китайской дипломатии» [4]. Ключевым из них представляется начатый в 2004 г. проект по открытию институтов Конфуция, рассчитанных на распространение китайского языка и культуры по всему миру, прежде всего в развивающихся странах. В сентябре 2007 г. в Мехико начал работу первый институт Конфуция в Латинской Америке, а к январю 2014 г. подобных культурно-образовательных учреждений в странах региона насчитывалось уже более 30 [31], что свидетельствует об эффективности данного инструмента китайской внешней политики. Наряду с деятельностью официального Пекина по улучшению имиджа Китая в регионе в контексте теории международных отношений интерес представляют политические аспекты вовлечения в региональную подсистему международных отношений нового доминирующего субъекта.

Несмотря на высокую актуальность затронутой тематики и растущий интерес к ней мирового научно-экспертного сообщества, количество носящих исследовательский характер русскоязычных публикаций по теме стратегии развития отношений КНР со странами Латинской Америке весьма ограничено. Проблематика отношений между Китаем и латиноамериканскими государствами в национальной науке фактически не исследовалась, за исключением работ профессора БГУ Ю. И. Малевич, посвященных изучению двустороннего сотрудничества указанных акторов международных отношений в сферах культуры, науки и образования [4]. В то же время обширные сведения по внешней политике Бразилии и Венесуэлы содержатся в текстах по отечественной латиноамериканистике профессора БГУ А. А. Челядинского $[7,8]$.

В Российской Федерации данный предмет исследования получил несколько большую разработку. В частности, широкомасштабная 
экономическая и политическая деятельность Китая в регионе освещена в работах сотрудников Центра иберийских исследований при Институте Латинской Америки РАН. Из их числа следует отметить труды руководителя центра, профессора Российского экономического университета им. Г. В. Плеханова П. П. Яковлева [9, 10], предметом исследований которого выступают отношения между КНР и государствами Латинской Америки в экономической сфере, а также ведущего научного сотрудника ИЛА РАН Э. С. Дабагяна $[1,2]$, в которых последовательно изложена сущность концептуальных взглядов на китайско-американские отношения со стороны экспертного сообщества Российской Федерации. Некоторые особенности внешней политики КНР на современном этапе раскрываются в научных публикациях доцента кафедры американских исследований ФМО СПбГУ Я. В. Лексютиной [3]. В контексте компаративного метода обращают на себя внимание работы доцента СПбГУ Е. Б. Павловой, посвященные сравнительному анализу политических процессов в Латинской Америке и на постсоветском пространстве [5].

Более детально заявленная тема исследована в научно-экспертных сообществах США, КНР и латиноамериканских стран, для которых затронутая проблематика наиболее актуальна. Особенно ценными представляются публикации экспертов, которые были непосредственно вовлечены в процесс принятия политических решений или реализации достигнутых договоренностей (бывшие и действующие сотрудники внешнеполитических ведомств, консультанты глав государств и правительств, например, бывший заместитель государственного секретаря по вопросам Западного полушария А. Валенсуэла [32], руководитель программ по Латинской Америке международного исследовательского центра им. В. Вильсона, консультант по вопросам внешней политики при администрациях Дж. Картера и Р. Рейгана С. Арнсон [12], бывший посол Китая в Аргентине, Кубе и Эквадоре Сю Ицун [15]).

На этом фоне альтернативным взглядом на затронутую в статье проблематику выделяются китайские исследователи, начавшие предметно разрабатывать латиноамериканский вектор с 2008 г., в частности представители Шанхайского института международных исследований (SIIS) [22], а также их коллеги из Латинской Америки, например ректор Университета во имя мира (Universidad para la Paz, штабквартира в Коста-Рике) при ООН чилиец Ф. Р. Аравена [27]. С точки 
зрения описательного метода представляют интерес материалы печатных и электронных латиноамериканских средств массовой информации, обширная фактологическая база представлена на официальных страницах органов государственного управления и международных региональных организаций в интернете.

Активная деятельность Китайской Народной Республики в Западном полушарии представляет актуальный и востребованный объект исследования. Вместе с тем до настоящего времени в дискурсе международных отношений отсутствует методологически обоснованный анализ политических аспектов региональной стратегии Китая в Латинской Америке. Концентрация большинства исследователей исключительно на вопросах экономического характера, безусловно, необходимых для комплексного анализа данной проблематики, ведет к игнорированию не менее важного политического содержания китайско-латиноамериканского сотрудничества. В данной статье автор ставит цель проанализировать состояние и перспективы двусторонних отношений КНР и некоторых государств Латинской Америки, а также исследовать степень их влияния на развитие региональной подсистемы международных отношений.

Наиболее наглядно правомерность дифференцированного подхода к оценке и анализу сотрудничества Пекина с различными латиноамериканскими странами проявляется в сравнении двусторонних отношений КНР с государствами, ориентированными во внешней политике на США, и со странами, управляемыми правительствами левого толка. Так, подход, основанный на примате экономической сферы и применимый к Мексике, Чили, Перу, Уругваю, не позволяет адекватно проанализировать весь комплекс отношений Китая с Бразилией, Венесуэлой и Кубой, охватывающий также такие области, как безопасность [9], культура и образование[4].

При этом следует отметить, что для латиноамериканских государств сотрудничество с КНР отнюдь не означает жесткой оппозиции Соединенным Штатам. В отличие от Венесуэлы Бразилия регулярно выступает с критикой в адрес Вашингтона, не примыкая при этом к лагерю государств - оппонентов США на международной арене [12]. Бразильско-американские отношения, прежде всего в экономической сфере, поступательно развиваются, несмотря на ряд сложных вопросов. Это осуждение бразильской стороной наращивания присутствия вооруженных сил США в Колумбии, позиции Вашингтона в ходе по- 
литического кризиса в Гондурасе в 2009 г. и незаконной деятельности американского разведывательного сообеесва в отношении глав государств и правительств Латинской Америки. В свою очередь администрация Б. Обамы неоднократно выражала недовольство поддержкой, которую Бразилия оказывает Ирану в вопросах развития атомной энергетики и преодоления внешнеполитической изоляции [7].

Отмеченные разногласия с Вашингтоном по политическим вопросам наряду с повышенным интересом китайских инвесторов к месторождениям полезных ископаемых на территории Бразилии способствовали активизации двусторонних китайско-бразильских отношений в последнее время. В частности, в июне 2012 г. Бразилию посетил премьер Государственного совета КНР Вэнь Цзябао. Наиболее значительным результатом переговоров китайской делегации с высшим политическим руководством Бразилии стало заключение сделки своп на сумму до 30 млрд долларов в национальных валютах обоих государств. Очевидно, что указанная сделка является частью более широкого соглашения стран - членов БРИКС, нацеленного на минимизацию последствий глобальных экономических кризисов. Кроме того, Китай и Бразилия обязались предоставлять друг другу более подробную финансовую информацию и увеличить поток инвестиций в аэрокосмическую сферу. В данном контексте весьма характерным представляется высказывание бывшего председателя совета директоров государственной нефтяной компании Petrobras C. Габриелли о том, что «среди руководства США нет ни одного человека, с которым можно было бы провести столь конструктивные переговоры, как с представителями КНР» [28].

В целом Бразилия является важнейшим экономическим партнером Китая в регионе, представляя собой как крупнейший рынок сбыта, так и источник сырья. По данным за 2013 г., товарооборот между двумя странами составил около 90,27 млрд долларов [13]. КНР является потребителем бразильской сельскохозяйственной продукции, в частности на Бразилию приходится $45 \%$ китайского импорта сои. Схожая ситуация сложилась с продукцией металлургических и нефтеперерабатывающих предприятий, наладивших тесные производственные связи с Китаем. Многочисленное население с относительно высокой покупательной способностью обусловило привлекательность бразильского рынка для китайских производителей. Перспективными направлениями двустороннего сотрудничества также явля- 
ются атомная энергетика (Бразилия обладает значительныли запасами урана и высокотехнологичными разработками в энергетической сфере) и аэрокосмическая отрасль [30].

Важный элемент бразильско-китайских отношений на современном этапе - взаимодействие двух стран в рамках БРИКС, которое развивается наиболее быстрыми темпами среди государств - участников данного объединения. По данным Центрального банка Бразилии, товарооборот с Китаем увеличился более чем в 13 раз за десятилетие (с 6,7 млрд долларов в 2003 г. до 90,27 млрд долларов в 2013 г.) [14]. Бразилиа и Пекин также активно координируют позиции по наиболее актуальным вопросам международной повестки дня, прежде всего по поддержанию многополярного миропорядка и повышению роли международных организаций, обеспечению устойчивого развития, а также противодействию климатическим изменениям [26].

Рассматривая влияние механизма БРИКС на развитие двусторонних отношений, научный сотрудник Института Латинской Америки Китайской академии современных международных отношений Сунь Яньфэн пришел к выводу, что именно встречи глав государств в рамках саммитов БРИКС послужили основным импульсом интенсификации взаимодействия между двумя странами, способствуя созданию атмосферы политического доверия [22].

В качестве примера можно привести 6-ю встречу руководителей стран БРИКС 15 июля 2014 г. в г. Форталезе (Бразилия), а также последовавшее за ней турне Си Цзиньпина по странам региона (Аргентина, Венесуэла и Куба). На данном саммите лидеры Китая и стран Латинской Америки объявили об официальном создании форума Китай - СЕЛАК в соответствии с принятым в январе 2015 г. решением. Ожидается, что первое заседание форума на уровне министров иностранных дел пройдет в Пекине уже в текущем году [17].

Схожесть современного политического дискурса в КНР, большинстве латиноамериканских государств и России обусловила качественные изменения в рамках БРИКС [5]. Новым аспектом сотрудничества стало инициированное Российской Федерацией создание совместных проектов в военно-технической сфере. При этом данное перспективное направление вызывает интерес не только у России, лишившейся на фоне украинского кризиса возможности конструктивно взаимодействовать с западными государствами, но и у Китая. Пекин уже проявил интерес к бразильским разработкам в области штурмо- 
вой и военно-транспортной авиации, а также аэрокосмической отрасли. Указанные тенденции демонстрируют, что БРИКС находится в стадии перехода от сугубо экономического взаимодействия к политическому (в том числе военно-политическому) сотрудничеству [3].

Исходя из вышеприведенного, не выглядит преувеличением точка зрения политолога Ню Хайбина из Шанхайского института международных исследований о том, что китайско-бразильское партнерство может служить примером парадигмы международных отношений «Юг - Юг» [20, р. 241].

Схожую по значению роль для Китая играет развитие сотрудничества с Венесуэлой. Об этом свидетельствует тот факт, что Пекин за последнее время предоставил Боливарианской Республике около 50 млрд долларов в виде кредитов и инвестиций в обмен на привилегированный доступ к ее нефтяным ресурсам. Двустороннее взаимодействие в области добычи и переработки нефти может служить темой отдельного исследования [18].

Однако, учитывая тематические рамки данной статьи, следует особо отметить, что наряду с экономической значимостью китайсковенесуэльские отношения носят ярко выраженный политический характер.

Так, официальные представители обеих стран неоднократно подчеркивали, что расширение сотрудничества в энергетической сфере соответствует политике руководства двух государств, направленной на создание многополярного мира и диверсификацию рынков нефтепродуктов [33, p. 3].

Переход китайско-венесуэльских отношений на уровень стратегического партнерства стал возможным во многом благодаря активным усилиям президента Венесуэлы У. Чавеса, рассматривавшего КНР в качестве примера успешного сочетания социализма в политике и рыночного курса в экономике [8].

Однако наступившая после кончины лидера «боливарианской революции» неопределенность во внутриполитической ситуации в стране вызвала серьезную обеспокоенность Пекина, что подтверждается опубликованными на сайте Wikileaks документами исследовательского центра Стратфор и государственного департамента США. Очевидно, что возможная смена власти в Венесуэле ставила под угрозу статус особого партнера Китая и, соответственно, доступ к венесуэльским энергетическим ресурсам [2]. 
В данном контексте не вызывает удивления поддержка, оказанная Пекином новому главе венесуэльского государства как в период подготовки к досрочным президентским выборам, так и непосредственно после них. Уже 8-9 марта 2013 г. Каракас посетил заместитель председателя Постоянного комитета Всекитайского собрания народных представителей Чжан Пин, принявший участие в официальной церемонии прощания с У. Чавесом и проведший переговоры с исполняющим обязанности президента Венесуэлы Н. Мадуро. По итогам встречи стороны подтвердили приверженность ранее достигнутым договоренностям и выразили готовность к дальнейшей интенсификации сотрудничества [23].

Последовавший в сентябре 2013 г. официальный визит главы венесуэльского государства в Пекин продемонстрировал сохранившееся исключительное значение китайского вектора внешней политики Каракаса. В ходе посещения КНР Н. Мадуро провел серию встреч с представителями высшего политического руководства Китая, принял участие в XII заседании Смешанной комиссии высокого уровня, по итогам которого подписаны 27 соглашений в различных сферах, включая финансы, энергетику, безопасность и сельское хозяйство.

В частности, Венесуэле был предоставлен очередной кредит в 5 млрд долларов, китайская государственная корпорация Sinipec получила право на создание совместного предприятия для освоения месторождения Южный Хунин-10 нефтеносного пояса р. Ориноко, в деятельность которого предполагается инвестировать 14 млрд долларов. В перспективе объем ежедневной добычи нефти в этом районе может достигнуть 200 тыс. баррелей. В настоящее время Венесуэла направляет в Китай около 600 тыс. баррелей нефти ежедневно, что составляет четвертую часть ее экспорта. Следует отметить, что помимо министра нефтяной и горнодобывающей промышленности Р. Рамиреса в состав венесуэльской делегации входила министр обороны адмирал К. Мелендес, подписавшая контракт с государственной корпорацией Citic на возведение штаб-квартир генеральных командований военно-воздушных и военно-морских сил Венесуэлы, а также обсудившая с китайскими партнерами состояние и перспективы военно-технического сотрудничества [21].

Импульс, приданный двусторонним отношениям первым официальным визитом Н. Мадуро в Китай, сохраняется. Так, во исполне- 
ние договоренностей, достигнутых по его итогам, 3 октября 2014 г. министр высшего образования, науки и техники Венесуэлы М. Фернандес заключил соглашение с китайской компанией «Великая стена» о создании и запуске третьего венесуэльского космического спутника «Сукре» [32].

В целом представляется очевидным, что преемник У. Чавеса пользуется поддержкой Пекина, который по-прежнему рассматривает Венесуэлу в качестве не только важного экономического партнера, но и ключевого политического союзника в Латинской Америке, способствующего продвижению китайских национальных интересов на континенте.

В Карибском бассейне Китай прежде всего заинтересован в укреплении связей с Кубой по причине уникального геополитического положения этого островного государства. Отмечая важность внутриполитических процессов в Республике Куба, представители руководства КНР неоднократно заявляли о поддержке инициированных P. Кастро и одобренных VI съездом Коммунистической партии Кубы в апреле 2011 г. экономических и политических преобразований, в основании которых во многом заложена модель китайского «рыночного социализма» [25].

В свою очередь руководство Республики Куба сотрудничество с Китайской Народной Республикой рассматривает не только как возможность привлечения крупных инвестиций, но и как своего рода гарантию стабильного развития кубинского государства и противовес враждебной политике Вашингтона [15]. Столкнувшись с серьезными социально-экономическими трудностями после прекращения помощи со стороны СССР, известными как «особый период», Куба начала диверсифицировать свою внешнюю политику в поисках новых союзников. С приходом к власти У. Чавеса таким стратегическим партнером стала Венесуэла. Однако, учитывая обострившуюся в последнее время внутриполитическую ситуацию в этой стране, правительство Р. Кастро придает все возрастающее значение развитию сотрудничества с Китаем.

Важной вехой китайско-кубинских отношений на современном этапе представляются визиты в Гавану председателя КНР Ху Цзиньтао в ноябре 2008 г. и его заместителя (в последующем, как известно, и преемника) Си Цзиньпина в июне 2011 г. По итогам переговоров было подписано около десятка соглашений, основными из которых 
были договоренности об участии Китая в модернизации нефтеперерабатывающего завода в г. Сьенфуэгос и открытии новой кредитной линии [24]. В июле 2014 г. Си Цзиньпин снова посетил Кубу уже в статусе председателя КНР. В ходе визита состоялись встреча с лидером Кубинской революции Ф. Кастро и переговоры с председателем Государственного совета Р. Кастро. Подписаны соглашения о сотрудничестве в сферах торговли, сельского хозяйства, биотехнологий, культуры и образования [16].

Двусторонние отношения КНР с государствами Центральной Америки и Карибского бассейна имеют еще один немаловажный подтекст. Помимо нефтеперерабатывающего завода в Коста-Рике, добычи бокситов в Гайане и развития логистической инфраструктуры интересы Пекина в данном регионе простираются также и на сферу дипломатии.

Речь идет о тайваньском вопросе: из 23 государств мира, имеющих дипломатические отношения с Тайбэем и автоматически не имеющих таковых с Пекином, пять находятся в Центральной Америке (Гватемала, Гондурас, Никарагуа, Панама, Сальвадор) и шесть - в Карибском бассейне (Белиз, Гаити, Доминиканская Республика, Сент-Китс и Невис, Сент-Люсия, Сент-Винсент и Гренадины). Следует отметить, что многие из этих стран имеют тесные торгово-экономические связи с тайваньскими компаниями. С целью переориентации указанных государств на сотрудничество с КНР Пекин с 2008 г. открыл кредитную линию на 530 млн долларов под совместные проекты, запустил программы в сферах туризма и образования, а также стал акционером Карибского банка развития [19].

Приведенные примеры использования Китаем двусторонних отношений с целью продвижения своих политических и экономических интересов в Латинской Америке, вероятно, наиболее показательны, однако ими далеко не исчерпывается весь комплекс китайско-латиноамериканского взаимодействия. Так, Пекин инвестирует в добычу железной и медной руды в Перу и Чили соответственно, текстильную промышленность Мексики, совместное освоение Антарктики с Аргентиной и Чили. Соглашения о сотрудничестве в сферах культуры, образования, спорта и туризма подписаны с десятью государствами региона [9].

С целью обобщения и систематизации разнородных проявлений стратегии КНР в Латинской Америке целесообразно выделить как 
минимум следующие формы взаимодействия на двусторонней основе:

- развитие политико-экономических связей с одним из государств до уровня стратегического партнерства с целью последующего его использования для установления отношений с международными региональными организациями и расширения своего влияния в регионе;

- акцент на интенсификации отраслевого экономического сотрудничества в среднесрочных тактических интересах;

- уклон в сторону военного и военно-технического сотрудничества, а также взаимодействия в гуманитарной сфере с целью закрепления в качестве одного из субъектов региональной подсистемы международной безопасности;

- поощрение культурных и образовательных связей для улучшения имиджа Китая в регионе;

- консолидацию позиций по актуальным вопросам международной повестки и согласование дипломатических шагов с целью получения внешнеполитической поддержки, например по вопросу признания Тайваня или правозащитной тематике.

Из числа объективно негативных факторов, формирующих определенную настороженность у латиноамериканских партнеров Китая, в первую очередь следует отметить:

- нацеленность большинства инициатив КНР прежде всего на удовлетворение собственных нужд в сырье, в результате чего многие китайские компании реализуют проекты по добыче и переработке ресурсов, не оказывая влияния на развитие технологий в странах - peципиентах инвестиций;

- жесткий контроль правительства Китая над совместными проектами;

- модели поведения китайских инвесторов в социальной и экологической сферах;

- несоответствие официальной статистики по прямым инвестициям Китая в экономику региона реально поступающим финансовым средствам, обусловленное выводом китайскими компаниями части средств в оффшорные зоны [11].

С точки зрения теории международных отношений также представляют интерес политические дивиденды, извлекаемые руководством некоторых государств Латинской Америки от подобного сотруд- 
ничества. Несмотря на очевидную экономическую направленность заключенных соглашений и нейтральную в политическом плане риторику китайской стороны, представители правительств латиноамериканских государств левого толка (Кубы, Венесуэлы, Боливии, в меньшей степени - Эквадора и Аргентины) склонны придавать отношениям с КНР характер совместной борьбы за создание многополярного мирового порядка в противовес доминированию США [6; 22].

Таким образом, экономическое сотрудничество приобретает для руководителей указанных государств новое значение - партнерство с Китаем призвано продемонстрировать успешность их внешней политики, а также рост авторитета на международной арене, что способствует повышению популярности среди электората внутри страны.

Представляется целесообразным учитывать наличие подобной мотивации у латиноамериканских политиков при анализе текущего состояния и перспектив отношений по линии КНР - Латинская Америка.

\section{Библиографические ссылки}

1. Дабагян Э. С. Китайский прорыв в Латинскую Америку // Мировая экономика и междунар. отношения. - 2012. - № 10. - С. 84-91.

2. Дабагян Э. С. Венесуэла после Уго Чавеса // Мировая экономика и междунар. отношения. - 2014. - № 7. - С. 67-77.

3. Лексютина Я. В. Китай в БРИКС : мотивация участия // Мировая экономика и междунар. отношения. - 2014. - № 4. - С. 81-89.

4. Малевич Ю. И. Культурные связи КНР со странами Латинской Америки // Труды факультета международных отношений БГУ : сб. науч. тр. Вып. 3. / редкол.: В. Г. Шадурский (гл. ред.) [и др.]. - Минск : БГУ, 2012. - С. 18-22.

5. Павлова Е. Б. О тождестве противоположностей : Россия и Латинская Америка // Свободная мысль. - 2010. - № 10 (1617). - С. 109-120.

6. Предстоящая поездка Си Цзиньпина в Латинскую Америку посвящена взаимовыгодному сотрудничеству // Жэньминь жибао [Электронный ресурс]. - URL : http://russian.people. com.cn/n/2014/0711/c31521-8754084.html (дата обращения : 23.07.2014).

7. Челядинский $A$. А. Бразилия в современном мире. - Минск : Право и экономика, 2012.

8. Челядинский A. A. Венесуэла: от Боливара до Чавеса : в 2 ч. - Минск : Право и экономика, 2013. - Ч. 2 : 1999-2013 гг.

9. Яковлев П. П. Латинская Америка в глобальной стратегии Пекина // Фонд ист. перспективы [Электронный ресурс]. - URL : http://perspectivy.info/oykumena/amerika/latinskaja_ amerika_v_globalnoj_strategii_pekina_2010-11-02.htm (дата обращения : 23.10.2013).

10. Яковлева Н. М., Яковле, П. П. Большая нефтяная игра : причины и последствия национализации компании YРF // Латинская Америка. - 2012. - № 11. - С. 70-93; № 12. - С. $27-42$. 
11. 22.000 clientes de China ocultos en paraísos fiscales // El País [Electronic resource]. - URL : http://internacional.elpais.com/internacional/2014/01/21/actualidad/1390321114_112551.html (date of access : 03.06.2014).

12. Arnson C. J., Davidow J. (ed.). China, Latin America and the United States : the New Triangle. - Woodrow Wilson International Center for Scholars, 2011.

13. Balance Preliminar de las Economias de America Latina y el Caribe / CEPAL [ed. J. A. Fuentes]. - Santiago de Chile : Naciones Unidas, 2014.

14. Brazilian Capital Abroad // Banco Central do Brasil [Electronic resource]. - URL : http://www4.bcb.gov.br/rex/CBE/Ingl/CBE2013Results.asp (date of access : 16.08.2014).

15. Certificado Pepino Xu Yicong : Memorias de diplomáticos // CCTV-Español [Electronic resource]. - URL : http://espanol.cntv.cn/program/Dialogo/20110730/103141.shtml (date of access : 12.07.2012).

16. China, Cuba sign a number of accords // Xinhuanet [Electronic resource]. - URL : http://news.xinhuanet.com/english/video/2014-07/24/c_133508205.htm (date of access : 27.07.2014).

17. Chinese president $\mathrm{Xi}$ arrives in Fortaleza for the BRICS summit // MercoPress [Electronic resource]. - URL : http://en.mercopress.com/2014/07/15/chinese-president-xi-arrives-in-fortalezafor-the-brics-summit (date of access : 23.07.2014).

18. Ferchen M. China and Venezuela : Equity Oil and Political Risk // China Brief. - 2013. № 3. - P. 9-13.

19. Foreign direct investment // UNCTAD [Electronic resource]. - URL : http://unctadstat. unctad.org/wds/ReportFolders/reportFolders.aspx (date of access : 14.08.2014).

20. Klemm B., Niu Haibin (ed.). China, the EU and Latin America : Current Issues and Future Cooperation. - SIIS, Friedrich Ebert Stiftung, 2011.

21. Maduro persigue la Alianza Estratégica que construyó Hugo Chávez con China // Sibci [Electronic resource]. - URL : http://www.sibci.gob.ve/2013/09/maduro-construyo-esta-alianzaestrategica-que-construyo-hugo-chavez-con-china (date of access : 14.06.2014).

22. Niu Haibin. BRICS in Global Governance: A Progressive and Cooperative Force? // FES [Electronic resource]. - URL : http://library.fes.de/pdf-files/iez/global/10227.pdf (date of access : 25.09.2013).

23. Presidente Nicolás Maduro y Delegación china ratificaron alianza de cooperación estratégica // Venezolana de Televisión [Electronic resource]. - URL : http://www.vtv.gob.ve/articulos/ 2013/03/09/presidente-encargado-nicolas-maduro-se-reune-con-delegacion-china-6397.html (date of access : 18.04.2013).

24. Rainsford $S$. Cuba looks to China for inspiration // BBC News [Electronic resource]. - URL : http://www.bbc.co.uk/news/business-18735790 (date of access : 10.09.2012).

25. Ratifican excelencia de nexos entre Cuba y China // Granma Internacional [Electronic resource]. - URL : http://www.granma.cu/espanol/2010/mayo/mar4/retifican.html (date of access : 14.04.2012).

26. Relations with China from the Perspectives of Brazil and U.S. Global Businesses // Woodrow Wilson International Center for Scholars [Electronic resource]. - URL : http://www.wilsoncenter. org/event/relations-china-the-perspectives-brazil-and-us-global-businesses (date of access : 15.11.2012).

27. Rojas Aravena F. Global Shifts and Changes in Latin America. - Berlin : Friedrich Ebert Stiftung, 2013.

28. Siega $V$. ¿Cuál es el interés de China en América Latina? // Observatorio Económico Latinoaméricano [Electronic resource]. - URL : http://www.obela.org/contenido/cual-es-interes-chinaamerica-latina (date of access : 22.01.2014). 
29. Sustaining U.S. Global Leadership: Priorities for 21st Century Defense // Department of Defense [Electronic resource]. - URL : http://www.defense.gov/news/defense_strategic_guidance.pdf (date of access : 28.09.2014).

30. Tokatlian J. G. ¿Cuán poderoso es Brasil? // Foreign Affairs Latinoamérica. - 2013. № 10. - P. 25-31.

31. Una estrategia activa hacia América Latina // China Today [Electronic resource]. - URL : http://www.chinatoday.mx/eco/analys/content/2013-01/04/content_510119.htm (date of access : 17.12.2013).

32. Venezuela y China firman acuerdo de fabricación del satélite Sucre // Sibci [Electronic resource]. - URL : http://www.sibci.gob.ve/2014/10/venezuela-y-china-firman-acuerdo-defabricacion-del-satelite-sucre/ - (date of access : 06.10.2014).

33. Venezuela - China Relations Grow Following VP's Visit // Correo del Orinoco. - 2013. № 158. - P. 3-5.

\section{Политические отношения между КНР и некоторыми государст- вами Латинской Америки (Илья Резников)}

Пересечение интересов Соединенных Штатов и Китайской Народной Республики в любом отдельно взятом регионе мира в современных условиях способно оказать влияние на расстановку сил на международной арене в целом. По этой причине представляется вполне закономерным, что политическое, экономическое и военное присутствие КНР в Латинской Америке является объектом пристального изучения.

Начавшееся около двух десятилетий назад с установления стабильных экономических связей сотрудничество Китая и латиноамериканских государств вскоре распространилось на другие сферы, такие как политика, безопасность и культура. При этом внешней политике действующего руководства Китая в отношении стран Латинской Америки в полной мере присущи характерные особенности концепции «мягкой силы». Данная публикация посвящена особенностям «непрямого» продвижения Пекином национальных интересов в регионе на примере двусторонних отношений Китая с некоторыми латиноамериканскими государствами.

\section{Ключевые слова}

КНР; страны Латинской Америки; политическое сотрудничество; экономические отношения; политика «мягкой силы»; глобальные интересы; доминирование США; двусторонние отношения; «непрямое» продвижение интересов Китая. 


\section{Political relations between the People's Republic of China and certain Latin American countries (Ilya Reznikov)}

Intersection of the national interests of the United States and the People's Republic of China in any region of the world can in current conditions affect general situation on the international arena. Thus, it is absolutely logical that political, economic and military presence of the PRC in Latin America draws keen interest of the international scientific and expert community. The cooperation between China and Latin America started approximately twenty years ago with the creation of solid economic ties and rapidly spread into politics, security and culture. Notably, the regional strategy of China in Latin America possesses all the characteristic features of «soft power». The current article is dedicated to the specific features of Beijing's «indirect» realization of the national interests in the region on an example of bilateral relations with some Latin-American countries.

\section{Key words}

China; Latin-American countries; political cooperation; economic relations; the policy of «soft power»; global interests; the dominance of the United States; bilateral relations; «indirect» promotion of the interests of China.

Статья поступила в мае 2015 г.

Байчоров А.М. - доктор философских наук, профессор Белорусского государственного университета;

Есин Р. О. - доктор политических наук, профессор кафедры международных отношений Академии управления при Президенте Республики Беларусь. 


\section{МЕЖДУНАРОДНОЕ СОТРУДНИЧЕСТВО \\ В СФЕРЕ ИЗМЕНЕНИЯ КЛИМАТА \\ И ПОЗИЦИЯ РЕСПУБЛИКИ БЕЛАРУСЬ}

\section{О. П. Рубо}

соискатель кафедры международных отношений

факультета международных отношений

Белорусского государственного университета

УДК 551.583

Проблема изменения климата решается как на международном, так и на национальном уровнях. Деятельность мирового сообщества в этом направлении осуществляется при активном участии Организации Объединенных Наций. В настоящее время страны проводят работу по подготовке к заключению нового всеобъемлющего соглашения по климату. Ход переговорного процесса по этому вопросу в декабре 2015 г. в Париже продемонстрирует, удастся ли странам преодолеть политические и экономические противоречия и принять на себя конкретные количественные обязательства по сокращению выбросов.

Цель данной статьи - исследование развития международного сотрудничества по борьбе с глобальным изменением климата, а также анализ участия Республики Беларусь в международных усилиях по сокращению выбросов парниковых газов и изучение позиции страны в рамках климатического переговорного процесса.

Автором изучены документы ООН по проблеме изменения климата и ряд нормативных правовых актов, определяющих политику и меры по сокращению парниковых газов в Республике Беларусь. При проведении исследования автор опирался на работы белорусских (И. В. Войтехович [4]), российских (В. А. Горбанев [7], М. М. Лебедева [12]) и зарубежных (П. Г. Харрис [22]) исследователей. Использованы также материалы новостных информационных агентств.

Проблема изменения климата была включена в повестку конференции в Торонто в 1988 г., где были рассмотрены предложения по сокращению выбросов газов в атмосферу. Дальнейшие шаги были предприняты на Женевской конференции в ноябре 1990 г. Представители 135 государств приняли декларацию, призывающую снизить 
выбросы газов, которые вызывают парниковый эффект и ведут к изменению климата. Особое внимание климатическим изменениям уделялось на Конференции ООН по окружающей среде и развитию в Рио-де-Жанейро в 1992 г., которая была названа «Саммит Земли». На этой конференции была принята Рамочная конвенция ООН об изменении климата (РКИК ООН) [12, с. 370-371].

РКИК ООН была создана как основной инструмент международного сотрудничества по смягчению негативных последствий изменения климата. Ее цель заключается в том, чтобы «добиться во исполнение соответствующих положений Конвенции стабилизации концентрации парниковых газов в атмосфере на таком уровне, который не допускал бы опасного антропогенного воздействия на климатическую систему». РКИК ООН предполагает применение важнейшего принципа общей, но дифференцированной ответственности, принимающей во внимание различный уровень социально-экономического развития стран [17].

В 1995 г. в Берлине состоялась 1-я Конференция сторон РКИК $\mathrm{OOH}$, на которой развитые страны признали, что они несут основную ответственность за изменение климата. Был разработан «Берлинский мандат», в котором перед развитыми странами поставлена цель взять на себя количественные обязательства по сокращению выбросов и оказывать помощь наиболее уязвимым странам, страдающим от изменения климата [22, 5-6].

На конференции в Киото в 1997 г. были высказаны различные точки зрения на экологическую проблему и пути ее решения. Развитые страны заявили, что в XXI в. именно страны «глобального Юга», где некоторые государства развиваются крайне быстрыми темпами, будут лидировать по выбросам в атмосферу. В свою очередь Китай, Индия и многие присоединившиеся к ним государства утверждали, что на них не должно распространяться ограничение на выброс вредных веществ в атмосферу. Они аргументировали это следующим образом: во-первых, выбросы вредных веществ, которые производят развитые и развивающиеся страны, несопоставимы, а во-вторых, развивающиеся страны экономически не могут позволить себе такие выбросы уменьшить [12, с. 372].

Несмотря на разногласия, конференция завершилась подписанием Киотского протокола, который одобрили 159 государств. Согласно этому протоколу 38 промышленно развитых стран взяли на себя обя- 
зательства сократить свои выбросы в атмосферу относительно 1990 г. в период с 2008 по 2012 г., например, страны ЕС - на 8 \%, США - на $7 \%$, Япония - на $6 \%$ [12, с. 372-373]. Для оказания помощи индустриальным странам в достижении их обязательных целей и обеспечении сбалансированного развития развивающихся стран в рамках Киотского протокола было предложено три механизма: механизм чистого развития, проект совместного осуществления и торговля квотами [11].

Срок действия Киотского протокола, вступившего в силу в 2005 г., истекал 31 декабря 2012 г. Новое соглашение о совместных действиях для решения проблемы изменения климата планировалось принять в декабре 2009 г. в Копенгагене на 15-й Конференции сторон РКИК ООН. Однако в ходе переговорного процесса в полной мере проявились противоречия между развивающимися и развитыми странами. Развивающиеся страны, в том числе Китай и Индия, настаивали на продолжении Киотского протокола, накладывающего обязывающие условия на развитые страны, заставляя их сокращать выбросы парниковых газов. Другие «малые» развивающиеся страны, наиболее уязвимые к последствиям изменения климата, требовали принятия безотлагательных мер по ограничению повышения глобальной температуры, а также оказания им финансовой и технологической помощи для борьбы с последствиями глобального потепления. Итогом переговоров стало подписание Копенгагенского соглашения, в котором страны впервые согласились не допускать роста средней температуры более чем на $2{ }^{\circ} \mathrm{C}$. Соглашение предполагало реальное сокращение выбросов со стороны крупнейших стран - эмитентов парниковых газов. Оно также предусматривало финансовую и технологическую помощь беднейшим и наиболее уязвимым странам [7, с. 245].

16-я Конференция сторон РКИК ООН по проблеме изменения климата прошла в южноафриканском Дурбане 28 ноября - 11 декабря 2011 г. Страны-участницы пытались договориться о том, как быть с Киотским протоколом - единственным инструментом регулирования мирового рынка выбросов парниковых газов. После долгих согласований стороны договорились продлить соглашение. В Дурбане также была утверждена «дорожная карта» по подготовке нового соглашения, которое предполагалось разработать не позднее 2015 г. «Дурбанская платформа» предусматривала, что в новом соглашении будут участвовать все страны [5]. 
26 ноября - 8 декабря 2012 г. в Дохе (Катар) проходили 18-я Конференция сторон РКИК ООН и 8-е Совещание сторон Киотского протокола. В ходе переговоров было принято решение запустить второй период обязательств по Киотскому протоколу (с 2013 по 2020 г.) и начать разработку нового климатического соглашения. Одновременно были предложены решения и поправки в ряд пунктов статьи 3 Киотского протокола. Предполагалось, что совместные проекты и торговля квотами будут действовать только для стран, имевших доступ к этим механизмам в первом периоде. Несмотря на возражения делегаций Беларуси, Казахстана, России и Украины, значительно изменен принцип определения квот на основе взятых страной количественных обязательств [18]. Предусматривалось установление странам на второй период Киотского протокола ежегодной квоты газов, не превышающей средний уровень с 2008 по 2010 г. В то же время было принято решение, инициированное и предложенное Республикой Беларусь от имени стран с переходной экономикой, о том, что эта группа стран до 2020 г. освобождается от обязательств оказания финансовой помощи развивающимся странам [15].

На Конференции ООН по изменению климата в Варшаве в ноябре 2013 г. страны приняли решение «начать и усилить внутристрановую подготовку их намерений по национальным вкладам» для принятия нового всеобъемлющего климатического соглашения, которое должно вступить в силу с 2020 г. Кроме того, на переговорах развитые страны заявили о предстоящих взносах климатического финансирования для оказания поддержки действий развивающихся стран по сокращению выбросов и адаптации к изменению климата [20]. Таким образом, вместо конкретных обязательств по снижению выбросов страны были призваны сформулировать, в чем будет состоять их вклад в борьбу с глобальным изменением климата. В связи с этим исполнительный секретарь РКИК ООН К. Фигерес на итоговой прессконференции заявила: «Это изменение было внесено, чтобы суметь принять текст. Можно его интерпретировать по-разному. Что остается неизменным, так это то, что индустриализованные страны с большей степенью ответственности должны быть впереди. Но это не значит, что остальные страны останутся в стороне. Текст касается всех, каждый должен внести свой вклад» [19].

В декабре 2014 г. в Лиме (Перу) на очередной Конференции $\mathrm{OOH}$ по изменению климата страны-участницы подписали рамочное 
соглашение - основу всеобъемлющего соглашения по климату, которое должно прийти на смену Киотскому протоколу. Такое соглашение планируется принять на следующей Климатической конференции ООН в декабре 2015 г. в Париже. Из-за сохраняющихся разногласий между развитыми и развивающимися странами переговоры были чрезвычайно напряженными. Такие страны, как Индия, Китай, Саудовская Аравия и Венесуэла, настаивали на «дифференцированной ответственности». Бедные страны призывали включить в соглашение конкретные обязательства для богатых стран по оказанию финансовой помощи, чтобы бедные государства смогли адаптироваться к последствиям глобального изменения климата [21]. Как говорится в заявлении пресс-секретаря главы ООН, Пан Ги Мун призвал страны участницы конференции как можно скорее внести в черновой вариант соглашения свои предложения и обязательства по борьбе с глобальным потеплением. Прежде всего это касается крупнейших экономик мира. В заявлении также отмечается, что на конференции в Лиме удалось пополнить Зеленый климатический фонд ООН. Такой фонд призван оказывать помощь развивающимся странам в деле адаптации к изменению климата. Предполагается, что с 2020 г. развитые страны будут ежегодно направлять в фонд 100 млрд долларов на эти цели [3].

Беларусь разделяет озабоченность мирового сообщества в связи с глобальным изменением климата и участвует в международных усилиях по сокращению выбросов парниковых газов. Беларусь подписала РКИК ООН 11 июня 1992 г. и ратифицировала ее 11 мая 2000 г., став полноправной стороной Конвенции. Страна подписала документ о присоединении к Киотскому протоколу 26 августа 2005 г. и 24 ноября 2005 г. стала стороной протокола [16, с. 7].

Следует отметить, что изначально Беларусь не входила в список стран, указанных в приложении В Киотского протокола, т. е. не имела количественных обязательств по сокращению выбросов парниковых газов в атмосферу. Такая ситуация лишала страну возможностей доступа к предусмотренным в рамках протокола рыночным механизмам противодействия глобальному изменению климата, т. е. проектам совместного осуществления и торговле квотами на выбросы [4, с. 74].

На 2-й Конференции сторон РКИК ООН в ноябре 2006 г. в Найроби (Кения) Республика Беларусь внесла поправку в приложение В, заявив тем самым о готовности взять на себя определенные количественные обязательства по сокращению выбросов. По итогам работы 
конференции было принято Решение 10/СМР.2 «Предложение Беларуси о внесении поправки в приложение В к Киотскому протоколу», согласно которому приветствовался тот факт, «что Республика Беларусь будет использовать любые доходы, полученные от продажи согласно статье 17 Киотского протокола, в целях принятия дальнейших мер по борьбе с выбросами парниковых газов, при условии получения на то согласия от соответствующих органов Республики Беларусь» $[9$, с. 55-56].

Инициатива Беларуси повысила привлекательность и авторитет страны как ответственного члена международного сообщества, готового вносить соразмерный вклад в общие усилия по борьбе с глобальным изменением климата. Беларусь взяла на себя обязательства по снижению уровня парниковых газов в 2008-2012 гг. на 8 \% по отношению к базовому 1990 г. Следует при этом отметить, что согласно соответствующим статьям Киотского протокола поправка к приложению В вступает в силу только при условии ее принятия не менее чем $75 \%$ сторон [4, с. 74-75].

Для выполнения количественных обязательств в Беларуси был принят ряд нормативных правовых актов, определяющих политику и меры по сокращению парниковых газов. В Стратегии снижения выбросов и увеличения абсорбции поглотителями парниковых газов в Республике Беларусь на 2007-2012 гг. были обозначены основные направления по смягчению воздействия на климат, наиболее значимые из которых связаны с повышением эффективности использования топливно-энергетических ресурсов во всех сферах хозяйственной деятельности. В августе 2008 г. в стране была утверждена Национальная программа мер по смягчению последствий изменения климата на 2008-2012 гг., которая предусматривала следующие меры: наблюдение за состоянием климата и его изменениями; сокращение выбросов из источников; адаптация отраслей экономики к изменениям климата; международное сотрудничество в борьбе с негативными последствиями изменения климата. Была также утверждена Стратегия участия Республики Беларусь в механизмах гибкости Киотского протокола в течение первого периода обязательств, и принят ряд других государственных программ [16, с. 70-72;102].

Несмотря на то что Беларусь приняла на себя обязательства по сокращению выбросов парниковых газов, разработала и ввела в действие нормативную базу и инфраструктуру, необходимую для их вы238 
полнения, страна столкнулась с проблемой ратификации поправки к приложению В.

В октябре 2010 г. на заседании Обзорной конференции Организации по безопасности и сотрудничеству в Европе Д. Сидоренко (в то время заместитель постоянного представителя Республики Беларусь при ОБСЕ) заявил: «Вступление в силу белорусской поправки к Киотскому протоколу... представляет первостепенный интерес для белорусской стороны.

Полномасштабное участие Беларуси в Киотском протоколе и включение страны в единую международную систему измерения, отчетности и верификации позволит Республике Беларусь возложить на себя долю ответственности за безопасное будущее планеты».

По его словам, замедление процесса ратификации белорусской поправки со стороны Европейского союза связано в первую очередь с отсутствием согласованности позиций между Еврокомиссией и странами - членами ЕС [6].

Однако несмотря на усилия отечественных экспертов, белорусская поправка так и не была ратифицирована необходимым количеством стран до конца 2012 г., когда завершился срок действия первого периода обязательств Киотского протокола. По мнению национального эксперта по вопросам изменения климата А. Гребенькова, если бы Беларусь получила доступ к механизмам углеродного финансирования, то страна смогла бы получить от продажи квот в 2008-2012 гг. до 200 млн евро [2].

Белорусская делегация во главе с О. Максютой, бывшим директором департамента по гидрометеорологии, принимала участие в 18-й Конференции сторон РКИК ООН в 2012 г. в Дохе. Делегация Беларуси активно работала на всех переговорных площадках, участвуя в контактных группах, многосторонних и двухсторонних неформальных консультациях с делегациями других стран.

Однако принятое решение о том, что предусмотренные в рамках Киотского протокола механизмы, такие как проекты совместного осуществления и торговля квотами, будут действовать только для стран, имевших доступ к этим механизмам в первом периоде, вызвало беспокойство у белорусской стороны.

Кроме того, решение об установлении до 2020 г. ежегодной квоты газов, не превышающей средний уровень с 2008 по 2010 г., подра- 
зумевало ограничение экономического роста Беларуси, и поэтому белорусская делегация заявила о неприемлемости такого подхода [18].

На заключительном этапе конференции делегациями Беларуси, России и Украины было подготовлено совместное компромиссное предложение, касающееся киотских правил. Однако председательство конференции не поставило на рассмотрение данное предложение [18].

Оценивая принятые в Дохе решения, представитель МИД Беларуси Ю. Ярошевич в январе 2013 г. заявил: «На конференции были зафиксированы обязательства в отношении менее чем 40 стран, которые на самом деле покрывают лишь 15 \% эмиссии, отсутствуют обязательства в отношении развивающихся стран, многие из которых выбрасывают гораздо больше парниковых газов, чем Беларусь, тем самым способствуют своему экономическому росту и конкурентным преимуществам по сравнению с нами». По словам Ю. Ярошевича, Беларусь придает первостепенное значение международному сотрудничеству, направленному на борьбу с изменением климата. «Мы заинтересованы в сбалансированных и эффективных многосторонних климатических механизмах, отвечающих интересам всех государств, включая страны с переходной экономикой», - отметил он [10].

Выступая на Конференции ООН по вопросам изменения климата в Варшаве в ноябре 2013 г., В. Гайсенок, бывший посол Республики Беларусь в Польше, заявил, что страна выражает озабоченность неравными условиями участия во втором периоде обязательств Киотского протокола. Представитель Беларуси отметил важность разработки прозрачных и четких правил процедуры принятия решений в рамках климатического переговорного процесса и подчеркнул необходимость активизации совместных действий сторон РКИК ООН по разработке нового соглашения [1].

В сентябре 2014 г. белорусская делегация во главе с премьерминистром М. Мясниковичем приняла участие во Всемирном климатическом саммите в Нью-Йорке. Руководитель белорусской делегации на саммите заявил об ответственном выполнении Беларусью своих обязательств в области климата, включая положения Киотского протокола. М. Мясникович призвал государства ООН до конца 2015 г. разработать новое всеобъемлющее соглашение по климату, которое предусматривало бы не только обязательства по сокращению выбросов, но и механизмы поощрения такого поведения государств. 
Общение с участниками заседания продемонстрировало, что они разделяют основные положения белорусской позиции. М. Мясникович также подчеркнул, что сегодня по вопросам климата имеется много разнообразных мнений о причинах изменений, возможных последствиях, отдельных механизмах соответствующих процессов. «В этом плане мне представляется, что должны быть проведены очень серьезные научные исследования, которые могли бы выявить эти основные подходы, причины и обстоятельства, которые ведут к изменению климата в глобальном масштабе», - отметил он [14].

По заявлению консультанта отдела регулирования воздействий на атмосферный воздух и озоновый слой Министерства природных ресурсов и охраны окружающей среды Беларуси И. Рудько, в стране проводится подготовка к конференции в Париже. Белорусские специалисты дорабатывают INDC страны (Intended nationally determined contribution - определяемые на национальном уровне вклады в борьбу с изменением климата). Также ведется работа по подготовке документов для утверждения их главой государства. Это указ о переговорном процессе, а также об обязательствах, которые Беларусь должна будет выполнить [13].

Беларусь продолжает уделять особое внимание предотвращению воздействия на климат. Об этом свидетельствует тот факт, что 21 июня 2013 г. в стране была утверждена Государственная программа мер по смягчению последствий изменения климата на 2013-2020 гг. Основные направления реализации программы: осуществление мероприятий по экономии топливно-энергетических ресурсов; стабилизация уровня выбросов парниковых газов за счет использования ресурсосберегающих технологий в энергоемких отраслях экономики; оптимизация сферы обращения с отходами; улучшение качества и увеличение объемов поглотителей парниковых газов. В программе предусматривается сокращение выбросов парниковых газов в 2020 г. на 8 \% к уровню 1990 г. Кроме того, планируется привлечение международной технической помощи для решения вопросов, связанных с изменением климата, а также привлечение иностранных инвестиций и технологий с низким уровнем выбросов парниковых газов в проекты, направленные на сокращение выбросов [8, с. 1-2; 10].

Таким образом, Беларусь намерена и далее отстаивать в рамках климатических соглашений положения, направленные на расширение международного сотрудничества по борьбе с глобальным изменением 
климата. В стране активно проводится работа по подготовке к конференции в Париже, определяется национальный вклад в борьбу с изменением климата. При этом Беларусь выступает за включение в новое всеобъемлющее соглашение по климату не только обязательств по сокращению выбросов, но и механизмов поощрения государств, ведущих активную работу по сокращению выбросов в атмосферу. Однако реальность такова, что политическая напряженность и экономические противоречия между странами затрудняют достижение приемлемого для всех государств компромисса, и будет ли принято новое глобальное соглашение по смягчению последствий изменения климата на предстоящей 21-й Конференции сторон РКИК ООН в Париже, станет ясно в декабре.

\section{Библиографические ссылки}

1. Беларусь выражает озабоченность неравными условиями участия во втором периоде обязательств Киотского протокола // БелТА [Электронный ресурс]. - URL : http://www.belta. by/ru/all_news/society/Belarus-vyrazhaet-ozabochennost-neravnymi-uslovijami-uchastija-vovtorom-periode-objazatelstv-Kiotskogo-protokola_i_652661.html (дата обращения : 26.05.2014). 2. Белявская $O$. Выиграет ли Беларусь от глобального потепления? // БелТА [Электронный pecypc]. - URL : http://www.belta.by/ru/person/comments/OlgaBeljavskaja_i_0000511228.htm (дата обращения : 02.05.2015).

3. В Лиме завершилась Конференция ООН по климату // Центр новостей ООН [Электронный pecypc]. - URL : http://www.un.org/russian/news/story.asp?NewsID=22840\#.VWck40hmy11 (дата обращения : 12.05.2015).

4. Войтехович И. В. Предотвращение глобального изменения климата как ключевой фактор устойчивого развития // Эколог. вестн. - 2011. - № 3 (17). - С. 73-78.

5. Bоропаев $B$. «Парник» проветрят. Киотскому протоколу готовят эффективную замену // Российская газета. [Электронный pecypc]. - URL : http://www.rg.ru/2011/12/11/ kiotskiiprotokol-site.html (дата обращения : 17.04.2015).

6. Выступление заместителя Постоянного представителя Республики Беларусь при ОБСЕ Д. Сидоренко на заседании Обзорной конференции ОБСЕ 25 октября 2010 г. // ОБСЕ [Электронный ресурс]. - URL : .http://www.osce.org/ru/home/73419?download=true (дата обращения : 02.05.2015).

7. Горбанев В. А. Глобальные изменения климата : от Рио до Канкуна // Вестн. МГИМО Ун-та. - 2011. - № 4 (19). - С. 240-249.

8. Государственная программа мер по смягчению последствий изменения климата на 20132020 годы // Совет Министров Респ. Беларусь [Электронный ресурс]. - URL : http://www. government.by/upload/docs/file231d5494644dba79.PDF (дата обращения : 10.05.2015).

9. Доклад Конференции сторон, действующей в качестве совещания сторон Киотского протокола, о работе ее второй сессии, состоявшейся в Найроби 6-17 ноября 2006 года // ООН [Электронный ресурc]. - URL : http://unfccc.int/resource/docs/2006/cmp2/rus/10a01r.pdf (дата обращения : 22.04.2015). 
10. Катикова А. Беларусь даст правовую оценку решению, принятому в Дохе на конференции по климату // БелТА [Электронный ресурс]. - URL : http://www.belta.by/ru/all_news/ economics/belarus-dast-pravovuju-otsenku-prinjatomu-v-doxe-resheniju-po-klimatu_i_621314.html (дата обращения : 28.04.2015).

11. Конвенция ООН об изменении климата и Киотский протокол // ООН [Электронный реcypc]. - URL : http://www.un.org/ru/climatechange/kyoto.shtml. (дата обращения : 11.05.2015).

12. Лебедева M. М. Экологические проблемы в международных отношениях // Современные международные отношения и мировая политика : учебник / отв. ред. А. В. Торкунов. - М. : Просвещение : МГИМО, 2004. - С. 366-381.

13. Леснова В. Парижское соглашение по климату, или Поиск компромисса // WildLife.by [Электронный pecypc]. - URL : http://www.wildlife.by/node/36323 (дата обращения : 20.05.2015).

14. Позиции Беларуси по вопросам климата поддержаны другими участниками саммита $\mathrm{OOH} / /$ БелТА [Электронный ресурc]. - URL : http://www.belta.by/ru/all_news/society/PozitsiiBelarusi-po-voprosam-klimata-podderzhany-drugimi-uchastnikami-sammita-OON_i_681116.html (дата обращения : 24.04.2015).

15. Представитель Минприроды: Наши национальные интересы состояли в том, чтобы вступить во второй этап Киотского протокола // БелАПАН [Электронный ресурс]. - URL : http://belapan.com/archive/2013/01/17/media_klimat_v2/ (дата обращения : 25.04.2015).

16. Пятое национальное сообщение Республики Беларусь в соответствии с обязательствами по Рамочной конвенции ООН об изменении климата // OOH [Электронный ресурс]. - URL : http://unfccc.int/resource/docs/natc/blr_nc5.pdf (дата обращения : 25.04.2015).

17. Рамочная конвенция Организации Объединенных Наций об изменении климата // ООН [Электронный ресурc]. - URL : http://www.un.org/ru/documents/decl_conv/conventions/climate_ framework_conv.shtml (дата обращения : 20.04.2015).

18. С 26 ноября по 8 декабря 2012 года в г. Доха, Государство Катар, проходила 18-я сессия Конференции сторон Рамочной конвенции ООН об изменении климата и 8-е Совещание сторон Киотского протокола // М-во природных ресурсов и охраны окружающей среды Респ. Беларусь [Электронный ресурс]. - URL : http://www.minpriroda.gov.by/ru/news-ru/view/s-26nojabrja-po-8-dekabrja-2012-goda-v-g-doha-gosudarstvo-katar-prohodila-18-aja-sessijakonferentsii-storon--1266/ (дата обращения : 07.05.2015).

19. Секретарь конвенции ООН: Страны должны бороться с изменением климата // РИА Новости [Электронный ресурс]. - URL : http://wap.ria.ru/global_warming/20131124/9792544 26.html (дата обращения : 02.05.2015).

20. Сообщение для прессы : Конференция ООН по изменению климата в Варшаве направляет страны на путь заключения климатического соглашения 2015 года // ООН [Электронный ресурс]. - URL : https://unfccc.int/files/press/press_releases_advisories/application/pdf/pr20132311_ cop19close_rus.pdf (дата обращения : 02.05.2015).

21. Nations Plod Forward on Climate Change Accord // The New York Times [Electronic resource] - URL : http://www.nytimes.com/2014/12/14/world/climate-change-summit-meeting-in-lima. html?_r=0 (date of access : 22.11.2014).

22. Politics of Climate Change: Environmental Dynamics in International Affairs / ed. P. G. Harris. - London : Routledge, 2009.

\section{Международное сотрудничество в сфере изменения климата и позиция Республики Беларусь (Олеся Рубо)}

Статья посвящена изучению международного сотрудничества по
проблеме изменения климата. В ней анализируются результаты кон- 
ференций по изменению климата, рассматриваются Рамочная конвенция ООН об изменении климата и Киотский протокол и оцениваются намерения государств заключить новое глобальное климатическое соглашение в 2015 г. в Париже. В работе особое внимание уделяется участию Беларуси в международных усилиях по сокращению выбросов парниковых газов и исследуется позиция страны в принятии решений в рамках климатического переговорного процесса. Делается вывод, что политическая напряженность и экономические противоречия между странами затрудняют достижение приемлемого для всех государств компромисса. Несмотря на этот факт, стороны РКИК $\mathrm{OOH,} \mathrm{включая} \mathrm{Беларусь,} \mathrm{на} \mathrm{настоящем} \mathrm{этапе} \mathrm{ведут} \mathrm{активную} \mathrm{работу}$ по определению национальных вкладов для заключения нового универсального климатического соглашения, которое, как планируется, должно вступить в силу с 2020 г.

\section{Ключевые слова}

Проблема изменения климата; международное сотрудничество; Рамочная конвенция ООН об изменении климата; Киотский протокол; посткиотский процесс; новое универсальное климатическое соглашение; позиция Республики Беларусь; климатическая политика Беларуси.

\section{International cooperation on climate change and the position of the Re- public of Belarus (Olesya Rubo)}

This article deals with international cooperation on climate change. The article analyzes the outcomes of the climate change summits, examines the Framework Convention on Climate Change and the Kyoto protocol and estimates countries' intention to reach a new climate agreement in Paris, in 2015. The paper pays particular attention to the participation of the Republic of Belarus in international efforts in reducing greenhouse gas emissions and examines country's position in decisions-making at the climate negotiations. Consequently, it is concluded that political tensions and economic differences between countries make it difficult to reach an acceptable compromise for all states. Despite this fact, the Parties to the UNFCCC, including Belarus, intensify currently preparation for their intended national contributions towards a universal climate agreement, which is expected to come into force from 2020. 


\section{Key words}

Climate change; international cooperation; the Framework Convention on Climate Change; the Kyoto protocol; Post-Kyoto Process; a new universal climate agreement; position of the Republic of Belarus; norms of Belarusian legislation in climate change.

Статья поступила в мае 2015 г.

\section{Рецензенты:}

Байчоров А. М. - доктор философских наук, профессор Белорусского государственного университета;

Есин Р. О. - доктор политических наук, профессор кафедры международных отношений Академии управления при Президенте Республики Беларусь. 


\section{СИСТЕМА УПРАВЛЕНИЯ ЗАРУБЕЖНЫМИ СВЯЗЯМИ \\ БЕЛОРУССКОЙ ССР ЧЕРЕЗ ПРИЗМУ УЧАСТИЯ \\ РЕСПУБЛИКИ В ЮНЕСКО (1954-1964 гГ.)}

\section{С. Ф. Свилас}

кандидат исторических наук,

дочент кафедры международных отношений

Белорусского государственного университета

УДК 008:061.1(100+476)ЮНЕСКО(091)

Общая характеристика системы управления зарубежными связями БССР в постсталинский период содержится в работах В. Е. Снапковского [8, с. 356-361], а культурными - В. Г. Шадурского [10, с. 63-90]. Цель автора предлагаемой статьи - рассмотреть действие этой системы, роль ее отдельных элементов на примере участия республики в многосторонней дипломатии ЮНЕСКО в годы хрущевской «оттепели». Статья написана главным образом на основе архивных материалов, рассекреченных в конце 1990-х гг., а они убеждают, что организатором и координатором сотрудничества республики с ЮНЕСКО следует считать Министерство иностранных дел БССР во главе с К. В. Киселевым.

В соответствии с Положением о Министерстве иностранных дел Белорусской ССР, утвержденным в 1948 г., оно являлось союзно-республиканским и в своей деятельности подчинялось как Совету Министров БССР, так и МИД СССР. На министерство возлагалось осуществление непосредственных отношений республики с иностранными государствами, заключение с ними соглашений и обмен дипломатическими и консульскими представительствами. По Положению 1961 г. основными задачами МИД были проведение в жизнь в соответствии с директивами правительств СССР и БССР внешней политики Советского государства, основанной на принципе мирного сосуществования, и защита в международных отношениях прав и интересов СССР и БССР, советских учреждений и граждан [7, ф. 907, оп. 1, л. 8-9].

На круглом столе в МИД Республики Беларусь, посвященном столетию со дня рождения К. В. Киселева (2003), вклад белорусской дипломатии второй половины XX в. в формирование многосторонне- 
го сотрудничества был определен как «весомый». Признавая «неполную самостоятельность белорусской внешнеполитической линии в советские годы», видный белорусский дипломат посол А. М. Герасименко отметил, что «именно в этот период Беларусь... вышла на международную арену в качестве субъекта международных отношений», «наш голос был слышен» [4, с. 131-132]. Исходя из критериев, установившихся в юридической науке [2, с. 87-89; 3, с. 25; 6, c. 13], а также изучения деятельности Белорусской ССР в ЮНЕСКО [8], Белорусскую ССР следует характеризовать как субъекта международного права, хотя и с ограниченной правоспособностью.

МИД Белорусской ССР получал всю информацию из Секретариата организации, которая затем направлялась в соответствующие республиканские ведомства (прежде всего, в созданную в октябре 1956 г. Комиссию Белорусской ССР по делам ЮНЕСКО, министерства просвещения, образования, культуры, Белорусское общество дружбы и культурной связи с заграницей, Академию наук, творческие союзы и др.). Сотрудники министерства с участием указанных ведомств вели переписку с Секретариатом организации, составляли ответы на его запросы; в МИДе формировался и состав делегаций на форумы ЮНЕСКО, куда обязательно включались дипломаты, готовились тексты выступлений делегатов.

К. В. Киселев принял активное участие в создании Комиссии Белорусской ССР по делам ЮНЕСКО, а также в учреждении должности Постоянного представителя республики при организации (1962 г.). Председателем Комиссии по делам ЮНЕСКО постановлением правительства был утвержден министр культуры Г. Я. Киселев, но заместителем председателя стал заместитель министра иностранных дел (сначала П. Е. Астапенко, а затем А. Е. Гуринович); с 1959 г. сотрудник внешнеполитического ведомства являлся ответственным секретарем указанного органа (сначала В. С. Колбасин, затем - Г. К. Новицкий). В 1962 г. К. В. Киселев высказался за то, чтобы Комиссия полностью перешла под патронаж МИД, что отразило бы реальное положение дел и повысило оперативность связи с организацией.

Вопросы членства республики в ЮНЕСКО (отчеты делегаций, ответственного секретаря Комиссии, постоянного представителя республики при ЮНЕСКО Б. В. Кудрявцева, переписка с Секретариатом, межведомственная координация) регулярно рассматривались на заседаниях коллегии (апрель 1957 г., январь 1959 г., апрель 1960 г., фев- 
раль 1961 г., август 1963 г.), а также на партийных собраниях и референтских совещаниях; состоялась встреча министра с генеральным директором ЮНЕСКО Р. Майо в Москве (август 1963 г.). Сотрудники министерства по предложению его руководителя занимались обобщением накопленного республикой опыта внешнеполитической деятельности, что нашло отражение в монографии «Белорусская ССР на международной арене» (1964), изданной в Москве, а также популяризацией ЮНЕСКО в республике посредством выступлений в печати, организации выставок и лекционной деятельности.

Республиканский МИД работал в соответствии с указаниями ЦК КПБ и МИД СССР. Состав делегаций на форумы ЮНЕСКО корректировался и утверждался сначала ЦК КПБ, а затем ЦК КПСС. Первым сотрудником Секретариата организации от республики стал В. В. Гаврилюк - ответственный секретарь журнала «Коммунист Белоруссии». Без союзной и республиканской «инстанций» не обходилась ратификация Президиумом Верховного Совета республики конвенций ЮНЕСКО, оформление и реализация заявок на проведение выставок, получение стипендий, субсидий для поездок туристических групп. Все дипломаты были коммунистами или комсомольцами, участвовали в работе парторганизации. Серьезным соперником союзного МИДа был Международный отдел ЦК КПСС; основанный в 1943 г. и непосредственно относящийся к Секретариату ЦК, в хрущевский период он занимал ступень выше внешнеполитического ведомства [5, c. 344].

МИД БССР находился под постоянным контролем республиканской «инстанции». В 1948 г. в ЦК КПБ поступило заявление сотрудника ведомства «т. Попова» о том, что К. В. Киселев «допускает теоретические ошибки», рассматривая социализм и коммунизм как две формации, игнорирует мнение министра государственной безопасности «т. Цанава» по вопросам приема иностранных и формирования белорусских делегаций, озвучивая оценку «чего с ними согласовывать, все равно они ни черта ни в чем не разбираются!», не желает «ставить вопросы на решение ЦК КП (б)», систематически нарушает требование о предварительной проверке принимаемых на работу лиц в МГБ, «мало работает над повышением идейно-политического уровня» [7, ф. 4-П, оп. 100, д. 24, л. 1-4].

В июне того же года вопрос был рассмотрен на заседании Бюро ЦК КПБ. В подготовленной по результатам проверки справке отме- 
чалось, что «деятельность МИД БССР... протекала в соответствии с общими принципами внешней политики Советского Союза. Белорусские делегации в ООН и ее органах, на международных конференциях и совещаниях, работая в полном контакте с делегациями СССР и руководствуясь указаниями МИД СССР, проводили правильную линию и умело отстаивали внешнюю политику Советского государства. Каких-либо принципиальных ошибок и отклонения от внешней политики нашего государства работники МИД, руководимые т. Киселевым, не допускали».

Вместе с тем проверка установила, что министерство не проявляло «должной инициативы и настойчивости в постановке перед ЦК ВКП (б), союзным правительством, МИД СССР новых вопросов и в подготовке материалов для дипломатических акций Советского государства за границей», в этом отношении «сильно отставало от МИД $\mathrm{YCCP».}$

Многие справки к международным конференциям и ГА ООН носили агитационный характер и оказались бесполезны, слушателей не удовлетворял семинар по истории международных отношений. Не использовались такие каналы для подготовки дипломатических кадров, как аспирантура, исторический и юридический факультеты. Министру было предложено «глубже вникать в работу министерства», навести порядок в кадровом и финансовом вопросах [7, ф. 4-п, оп. 100, д. 24, л. 5-16].

В 1958 г. состоялась еще одна проверка министерства республиканской «инстанцией», записка «О положении в Министерстве иностранных дел БССР» была направлена в январе 1959 г. заместителем заведующего административным отделом ЦК?КПБ А. И. Шипко и инспектором ЦК КПБ Р. Королевым первому секретарю ЦК КПБ К. Т. Мазурову.

В качестве «крупного недостатка» вновь было отмечено, что «министерство не проявляет должной инициативы в постановке вопросов перед ЦК КПБ, Совмином БССР с внесением их в ЦК КПСС, Союзное правительство, МИД СССР о дипломатических акциях Советского государства в ООН и за рубежом вообще», за «последние пять лет не было внесено ни одного вопроса, который бы рассматривался в ООН». Вся работа аппарата МИД главным образом направлялась на подготовку справок и досье к международным конференциям, 
многие из которых «составлены недоброкачественно, без глубокого знания дел и серьезного анализа».

МИД БССР вел переписку (ноты, информации, запросы, отчеты, ответы) с международными организациями от имени правительства БССР, причем «с ведома Министерства иностранных дел СССР и под его контролем», однако проверяющие сочли «ошибкой и совершенно ненормальным» такое положение, когда руководство МИД БССР осуществляло ее «без согласования даже важнейших вопросов» с ЦК КПБ и Советом Министров БССР. «В посланных справках ... не найдено политических ошибок, однако они страдают недостатками, многие вопросы, поднятые в справках, описаны поверхностно, даны недостаточно убедительные сравнения и т. п.».

В записке отмечалось, что аппарат МИД БССР «в основном укомплектован молодыми грамотными кадрами, недавно окончившими дипломатические вузы», из 15 «ответственно-оперативных работников» 12 коммунистов, по национальному составу белорусов -7 , русских -7 и украинцев - 1 человек. Указывались «их оторванность от жизни республики и ее местных руководящих органов, незнание республики, ее экономики и культуры» [7, ф. 4-п, оп. 53, д. 66, л. 613]. В апреле 1959 г. заведующий административным отделом ЦК КПБ В. Романов сообщил секретарю ЦК КПБ Т. Я. Киселеву, что записка о положении дел в МИД рассмотрена на заседании секретариата ЦК КПБ в присутствии министра иностранных дел БССР К. В. Киселева и заместителя министра иностранных дел БССР П. Е. Астапенко. Руководству министерства было предложено устранить недостатки в работе, отмеченные в записке [7, ф. 4-П, оп. 53, д. 66, л. 14].

$\mathrm{C}$ тех пор вопросы изучения дипломатами белорусской истории, культуры и языка стали предметом регулярного обсуждения на заседаниях коллегии, а вся направлявшаяся из Минска в штаб-квартиру ЮНЕСКО информация согласовывалась с ЦК КПБ и союзными инстанциями - МИД и Комиссией СССР по делам ЮНЕСКО, в ряде случаев подвергаясь доработке, что не способствовало оперативности, но повышало качество материалов.

В ответах на запросы ЮНЕСКО, выступлениях белорусских делегатов на ее конференциях обязательно делались ссылки на материалы съездов КПСС и третью программу партии. Содержание информационных материалов, идущих в Секретариат ЮНЕСКО, курировали секретари ЦК КПБ К. Т. Мазуров, П. М. Машеров, а также со250 
трудники отдела административных органов и отдела науки и культуры (Н. Ф. Капич, Г. А. Криулин, А. Т. Кузьмин, В. Р. Романов, Н. А. Халипов, Г. Г. Чернущенко, Б. Т. Шумилин).

Для совершенствования отбора кандидатов на поездки за пределы СССР, в том числе по линии ЮНЕСКО, в соответствии с указаниями ЦК КПСС республиканская «инстанция» в декабре 1959 г. создала специальную комиссию под председательством секретаря ЦК КПБ, куда вошли сотрудники аппарата ЦК, заместители руководителей Белорусского совета профсоюзов и Комитета государственной безопасности. Аналогичные комиссии были сформированы при обкомах Компартии Белоруссии [10, с. 83]. В июне 1960 г. ЦК КПБ «принял к сведению и неуклонному выполнению» указания ЦК КПСС, изложенные в письме «О повышении революционной бдительности». Он обязал руководителей министерств и ведомств республики усилить требовательность при отборе лиц, посылаемых за границу, не допускать в заграничные командировки и на зарубежную работу «случайных, болтливых, невыдержанных людей, неустойчивых в политическом и моральном отношении», а направлять только политически проверенных и квалифицированных работников, умеющих строго хранить государственную тайну, соблюдать интересы государства, добросовестно выполнять возлагаемые на них поручения, безупречных в личном поведении, высоко держащих честь и достоинство советского человека. При решении вопроса о направлении за границу следовало обязательно учитывать мнение первичной партийной организации [7, ф. 4-П, оп. 81, д. 1502, л. 130-132].

В июле 1960 г. Бюро ЦК КПБ еще раз подчеркнуло необходимость повышения требовательности к подбору лиц, выезжающих за границу, которые должны быть «политически проверенными, квалифицированными и морально устойчивыми работниками» [7, ф. 4-п, оп. 81, д. 1505, л. 6-10]. Сотрудник ЦК КПБ кандидат искусствоведения Э. П. Герасимович в 1960 г. была введена в состав Комиссии Белорусской ССР по делам ЮНЕСКО и в состав белорусской делегации на 11-й сессии Генеральной конференции (1960 г.).

В соответствии с рекомендациями ЦК КПБ вопрос изучения сотрудниками внешнеполитического ведомства белорусского языка и культуры обсуждался на двух заседаниях коллегии в апреле 1959 г. Представляется, что такое внимание связано с активизацией деятельности белорусской эмиграции в связи с 40-летием БНР (март 1958 г.) 
и БССР (январь 1959 г.) [1, д. 376, л. 12-23], со стремлением дипломатии республики добавить аргумент в споре о суверенитете Белорусской ССР, в частности в Секретариате ЮНЕСКО.

Выступая на заседании коллегии, К. В. Киселев подчеркнул: «Часть наших сотрудников не являются белорусами по национальности. Между тем они должны знать белорусский язык, уметь читать и говорить по-белорусски, знать все необходимые сведения о республике... Изучение белорусского языка и Белоруссии нам необходимо для дела. Комиссия ЦК КПБ отмечала как недостаток, что наши оперативные работники недостаточно знают белорусский язык, недостаточно знакомы с экономикой и культурой Белоруссии, которую они представляют на различных международных конференциях. Этот недостаток мы должны устранить». Министра поддержали члены коллегии Б. В. Кудрявцев, В. В. Греков, А. С. Зайцев. По мнению последнего, белорусский язык следовало сделать «основным» в министерстве.

В постановлении коллегии отмечалось, что «... коллектив сотрудников МИД БССР уделяет недостаточно внимания изучению жизни белорусского народа, сотрудники министерства редко выезжают с чтением лекций в области и районы республики, значительная часть сотрудников слабо владеет белорусским языком и в силу этого не в состоянии глубоко и всесторонне изучать белорусскую литературу и искусство».

Коллегия постановила «обратить внимание сотрудников министерства на необходимость глубокого и всестороннего изучения экономики, политики и культуры Белорусской ССР» и в этих целях обратилась в местком министерства с просьбой систематически организовывать экскурсии на промышленные предприятия, посещение театров, музеев, исторических и достопримечательных мест республики, чтение лекций о развитии народного хозяйства и культуры. Сотрудникам предписывалось предусмотреть в «индивидуальных планах по повышению идейно-теоретического уровня» ознакомление с произведениями литературы и искусства белорусского народа; посещать занятия по изучению белорусского языка (трижды в месяц по два академических часа) [1, д. 389, л. 88-96, 104]. Белорусскую дипломатическую элиту стимулировало в указанном направлении также то обстоятельство, что с июля 1959 г. по решению конгресса в США ежегодно проводилась Неделя «порабощенных народов». 
Одним из наиболее заинтересованных в сотрудничестве с ЮНЕСКО ведомств было Министерство просвещения (министр И. М. Ильюшин). Оно сыграло значительную роль во вступлении республики в Международное бюро просвещения (июль 1955 г.), создании и пополнении белорусской экспозиции на постоянной выставке, организованной Бюро в Женеве, ежегодно формировало делегацию во главе с министром на Международную конференцию по народному образованию, проводившуюся Бюро просвещения совместно с ЮНЕСКО. Заместитель министра просвещения С. А. Умрейко был бессменным членом Комиссии Белорусской ССР по делам ЮНЕСКО, участником 8-й (1954 г.), 10-й (1958 г.) и 11-й (1960 г.) сессий Генеральной конференции. Сотрудники министерства представляли материалы для белорусских делегаций к форумам ЮНЕСКО, а также для переписки с Секретариатом.

Результатом плодотворного научного сотрудничества в рамках ЮНЕСКО стала Международная конференция по радиоизотопам (1957 г., Париж), делегация на которую была сформирована в основном из ученых Академии наук БССР. Вице-президент академик К. К. Атрахович входил во все составы Комиссии Белорусской ССР по делам ЮНЕСКО, Фундаментальная библиотека вела активный обмен изданиями с крупнейшими книгохранилищами мира, ее директор Ф.В.Степанюк представлял республику на Международной конференции по книгообмену в Будапеште (1960г.), сотрудники Академии участвовали в написании статей для изданий ЮНЕСКО.

В состав Комиссии СССР по делам ЮНЕСКО, созданную в декабре 1955 г., вошел министр культуры БССР Г. Я. Киселев, ставший год спустя председателем республиканской Комиссии и возглавивший белорусскую делегацию на 9-й (1956 г.), 11-й (1960г.) и 12-й (1962 г.) сессиях Генеральной конференции. В вопросах сотрудничества с организацией целиком полагался на МИД и его руководителя К. В. Киселева. Так, на документе с предложением определить кандидатуру от республики в Комитет ЮНЕСКО по историческим памятникам, полученном в марте 1959 г. из Москвы, министр культуры написал: «Уважаемый Кузьма Венедиктович, я согласен. Прошу Вас поручить своим товарищам повести конкретно разговор о кандидатуре» [7, оп. 1, д. 404, л. 97].

В сформировавшейся к концу 1950-х гг. системе управления зарубежными культурными связями Белорусской ССР важная роль от253 
водилась Белорусскому обществу дружбы и культурной связи с зарубежными странами (БелОКС).

В 1958 г. с целью создания обществ дружбы с Советским Союзом произошла реорганизация Всесоюзного общества культурной связи с заграницей, на базе которого был создан Союз советских обществ дружбы и культурной связи с зарубежными странами (ССОД), а Белорусское общество культурной связи с заграницей, воссозданное в 1952 г., было реорганизовано в Белорусское общество дружбы и культурной связи с зарубежными странами (БелОД). Эта общественная структура, финансировавшаяся из государственного бюджета, находилась под полным партийно-государственным контролем [10, c. $87-88]$.

В июне 1958 г. ЦК КПБ принял постановление «О недостатках в работе Белорусского общества культурной связи с заграницей». Так как при отправке материалов «часто не учитывались их идейнохудожественные и политические качества», наблюдалась «неорганизованность в вопросах приема иностранных делегаций», выявлены случаи расточительства в расходовании государственных средств, член Комиссии БССР по делам ЮНЕСКО Г. Н. Вересов был освобожден от обязанностей председателя правления БелОКСа, а М. М. Ваганова - от обязанностей заместителя председателя правления [7, ф. 4-п, д. 1307, л. 37-40].

После этого место Г. Н. Вересова занял И. К. Козлов, а в октябре 1961 г. Бюро ЦК?КПБ утвердило председателем В. С. Смирнова, освободив его от обязанностей второго секретаря ЦК ЛКСМБ [7, ф. 4-П, оп. 81, д. 1619, л. 16].

В апреле 1963 г. Президиум ЦК КПБ рассмотрел вопрос «О мерах по дальнейшему улучшению деятельности Белорусского общества дружбы и культурной связи с зарубежными странами».

Отмечалось, что общество поддерживает контакты со 157 организациями 59 зарубежных стран, но «за границу направляются малосодержательные, сухие и неинтересные пропагандистские материалы», «недостаточно широко и умело» среди общественности зарубежных стран пропагандируются «исторические» решения XXII съезда КПСС и третья программа партии, советская действительность, достижения БССР в народном хозяйстве, науке и культуре. Республиканская инстанция указала, что общество не проявляет на- 
стойчивости в решении вопросов об издании книг и брошюр о республике, произведений белорусских писателей на иностранных языках, пассивно относится к тому, что мало выпускается белорусских документальных фильмов, которые можно направлять в зарубежные страны. «Дружественные и культурные связи» Белорусской ССР недостаточно освещаются в печати, по радио и телевидению.

Президиуму предписывалось «не допускать, чтобы за границу направлялись слабые произведения литературы и искусства, серые, неинтересные статьи, фотоподборки и другие пропагандистские материалы», улучшить качество перевода этих материалов на иностранные языки, «глубже освещать положение трудящихся этих стран и их борьбу за свои права, ярче показывать сущность капиталистического строя, кризис буржуазной культуры, активнее разоблачать буржуазную идеологию», воспитывать работников и активистов общества в духе высокой политической бдительности, непримиримости к любым проявлениям буржуазной идеологии, помогать им приобретать «навыки умелых и боевых пропагандистов нашей внутренней и внешней политики», тщательно проводить подготовку делегаций, туристских групп, выезжающих за границу.

Министерства культуры, иностранных дел, просвещения, высшего, среднего специального и профобразования, Госкомитет Совмина по координации научно-исследовательских работ, Академия наук, творческие союзы, Общество по распространению политических и научных знаний обязывались оказывать «всемерное» содействие и поддержку БелОКСу. В ЦК КПБ следовало представить план издания книг, брошюр и альбомов о развитии народного хозяйства, науки и культуры на иностранных языках, выпуска документальных фильмов для направления за границу и демонстрации зарубежным гостям. В целях улучшения межведомственной координации В. С. Смирнов был введен в состав коллегии МИД, а его заместитель В. А. Чернявская - в состав коллегии министерства культуры [7, л. 14-20]. Председатель правления общества (сначала Г. Н. Вересов, затем И. К. Козлов и В. С. Смирнов) входил в состав Комиссии Белорусской ССР по делам ЮНЕСКО.

Определенное место в управлении сотрудничеством Белорусской ССР с ЮНЕСКО занимало Белорусское общество по распространению политических и научных знаний - подразделение Всесоюзного общества, созданного в 1947 г. Более десяти лет его председа- 
телем был президент АН БССР В. Ф. Купревич, а затем его сменили сначала В. И. Антошин, затем В. Н. Позняк, которых «рекомендовало» к избранию Бюро ЦК КПБ. В сентябре 1959 г. Бюро последовало примеру Президиума ЦК КПСС, принявшего месяцем ранее постановление «О мерах по улучшению работы Всесоюзного общества по распространению политических и научных знаний». В постановлении шла речь о выполнении задач, поставленных XXI съездом КПСС в области идеологической работы, прежде всего по «коммунистическому воспитанию трудящихся». В 1959 г. в Обществе насчитывалось примерно 30 тыс. членов - «представителей интеллигенции и передовиков производства», прочитавших за год 270 тыс. лекций, в том числе 35 тыс. - по международному положению, а деятельность сосредотачивалась на «пропаганде пролетарского интернационализма, могущества мировой социалистической системы, миролюбивой внешней политики Советского правительства, непримиримой борьбе с враждебной буржуазной идеологией и современным ревизионизмом». Бюро ЦК КПБ приняло решение «со временем полностью перейти к безвозмездному чтению лекций» [7, ф. 4-П, оп. 81, д. 1440, л. 8, 80-88]. В 1960 г. В. Н. Позняк был введен в состав Комиссии Белорусской ССР по делам ЮНЕСКО, участвовал в работе 11-й (1960г.) и 12-й (1962 г.) сессий Генеральной конференции.

Реализацией субсидий ЮНЕСКО на ознакомительные поездки за границу занимался Белорусский республиканский совет профсоюзов. В мае 1959 г. его президиум принял постановление «О мерах по улучшению международных связей профсоюзов Белорусской ССР». В документе отмечалось, что они осуществляются «без должной целеустремленности», поездки не приносят практической пользы, а «больше носят экскурсионный характер», без популяризации достижений республики в коммунистическом строительстве, изучения профдвижения и жизни трудящихся, часто отсутствуют отчеты. Президиум Белорусского республиканского совета профсоюзов принял «К неуклонному руководству и исполнению» постановление Бюро ЦК КПБ «О мерах по улучшению организации командировок советских специалистов и других лиц за границу и об улучшении приема иностранцев в БССР», а также постановление Президиума ВЦСПС «О мерах по улучшению международных связей советских профсоюзов» того же года [7, ф. 4-п, оп. 53, д. 66, л. 42-45].

В апреле 1962 г. Бюро ЦК КПБ обсудило меры по выполнению 256 
постановления ЦК КПСС «Об упорядочении туристских связей с зарубежными странами».

В качестве туристов следовало направлять лиц, «подготовленных в деловом и политическом отношениях, безупречных в личном поведении, способных высоко держать честь и достоинство советского гражданина, строго хранить государственную тайну», «носителей высоких нравственных принципов строителя коммунизма». Руководители туристских групп отныне стали назначаться соответствующими министерствами, ведомствами и организациями республики и утверждаться комиссиями по выездам за границу при обкомах и ЦК КПБ.

Бюро подчеркнуло необходимость более эффективного использования туристских поездок для пропаганды решений XXII съезда КПСС и новой программы партии, достижений в коммунистическом строительстве, а также для изучения зарубежной науки и техники. Министерству культуры совместно с БелОКСом поручалось разработать тематику и обеспечить систематическое издание различной литературы на иностранных языках для распространения среди иностранцев, принять меры для выпуска диафильмов о республике и Минске, издать набор открыток, грампластинок и магнитофонных записей, создать новые документальные фильмы «об успехах трудящихся в развитии экономики, науки и культуры республики, о жизни города и деревни, об исторических и природных достопримечательностях Белоруссии» [7, л. 14-20].

ЦК ВЛКСМ (секретарь Л. М. Максимов) и Комитет молодежных организаций (председатель Г. Н. Жабицкий), отвергнув программы ЮНЕСКО по молодежному обмену и обучению за границей, по предложению МИД взяли на себя формирование и подготовку белорусской делегации к Международной конференции по делам молодежи в Гренобле (1964 г.).

Внешнеполитическое ведомство привлекало к сотрудничеству с ЮНЕСКО также творческие союзы. Союз художников участвовал в подборе репродукций для альбомов по искусству республики, часть тиража которых направлялась в библиотеки системы ОOH, а по просьбе Гендиректора ЮНЕСКО, переданной через МИД, на протяжении 1957-1958 гг. организовал подготовку работ для оформления нового здания Секретариата ЮНЕСКО (правда, не выдержавших 
конкурса). Союз писателей был подключен к отбору произведений белорусской литературы с целью их перевода и издания в Париже.

В августе 1960 г. Бюро ЦК КПБ, рассмотрев вопрос об издании и рецензировании иностранной художественной литературы в республике, приняло решение «отдавать предпочтение современным ведущим писателям стран соцлагеря, прогрессивным писателям капиталистических стран, а также лучшим произведениям литературы стран, порвавших с колониализмом и борющихся за национальную независимость».

Бюро обязало союз писателей «не допускать ничем неоправданного преувеличения роли произведений крупных представителей буржуазной литературы, вскрывать не только сильные, но и слабые стороны их творчества, формировать у читателя правильное представление о сложных процессах, происходящих в настоящее время в зарубежной литературе» [7, ф. 4-П, оп. 81, д. 1517, л. 7-8].

Таким образом, членство Белорусской ССР в ЮНЕСКО, ставшее одной из форм реализации принципа мирного сосуществования, обоснованного XX и XXII съездами КПСС, осуществлялось в условиях партийно-государственной монополии на международные связи в области образования, науки, литературы и искусства. Координатором деятельности республики в ЮНЕСКО являлся республиканский МИД, подконтрольный ЦК КПБ и союзному внешнеполитическому ведомству, осуществлявшим общее руководство. Определенное место в системе управления занимали министерства просвещения, культуры, Академия наук, Белорусское общество дружбы и культурной связи с зарубежными странами, Белорусское общество по распространению политических и научных знаний, Белорусский республиканский совет профсоюзов.

\section{Библиографические ссылки}

1. Архив Министерства иностранных дел Республики Беларусь. - Ф. 907. - Оп. 3.

2. Бредихин А. Л. Суверенитет как политико-правовой феномен. - М. : ИНФА-М., 2012.

3. Бровка Ю. П. Международная правотворческая деятельность Республики Беларусь : пособие для студентов фак. междунар. отношений. - Минск : БГУ, 2013.

4. 3 гісторыі дыпламатыі // Веснік М-ва замеж. спраў. - 2003. - № 4. - С. 131-132. 
5. Зонова Т. В. Дипломатия: модели, формы, методы : учебник для вузов. - М. : Аспект Пресс, 2013.

6. Мамедов У. Ю. Международная правосубъектность : автореф. дис. ... канд. юрид. наук. Казань, 2002.

7. Национальный архив Республики Беларусь. - Ф. 4-п. - Оп. 81. - Д. 1747.

8. Свилас С. Ф. Деятельность Белорусской ССР в ЮНЕСКО (1954-1964 гг.). Минск : БГУ, 2013.

9. Снапковский В. Е. История внешней политики Беларуси : пособие. - Минск : БГУ, 2013.

10. Шадурский В. Г. Культурные связи Беларуси со странами Центральной и Западной Европы (1945-1990-е гг.). - Минск : БГУ, 2000.

Система управления зарубежными связями Белорусской ССР через призму участия республики в ЮНЕСКО (1954-1964 22.) (Светлана Свилас)

На основе архивных документов рассмотрена система управления деятельностью Белорусской ССР в ЮНЕСКО в первые десять лет после вступления и выделены ее отдельные элементы. При этом отмечается, что республиканская система была частью общесоюзной, с ЦК КПСС на вершине. Партийное руководство интерпретировало мирное сосуществование, сотрудничество и соревнование социалистических и капиталистических государств в духовной сфере как форму классовой борьбы, аргументируя тем самым право на общее руководство и контроль.

В статье выявлена роль МИД республики как организатора и координатора оперативной деятельности БССР в ЮНЕСКО, охарактеризовано его взаимодействие с ЦК КПБ, Комиссией Белорусской ССР по делам ЮНЕСКО, другими ведомствами, а также с общественными организациями. Обширный фактический материал, отражающий управление деятельностью Белорусской ССР в ЮНЕСКО, в совокупности с критериями, разработанными юридической наукой, дает основание отнести республику к субъектам международного права, но с ограниченной правоспособностью.

\section{Ключевые слова}

Беларусь; ЮНЕСКО; хрущевская «оттепель»; многосторонняя дипломатия; МИД Белорусской ССР; ЦК КПСС; ЦК КПБ. 
Governance framework of foreign relations of the Belarusian SSR through its participation in UNESCO (1954-1964) (Svetlana Svilas)

On the basis of archival documents governance operations management system of the Byelorussian SSR in UNESCO in the first ten years after its entry is being reviewed and some particular elements of it are being highlighted. Whereby, it is noted that the republican system was part of the all-union one, with the CPSU Central Committee on top. The party leaders expounded peaceful coexistence, cooperation and competition between socialist and capitalist states in the spiritual realm as a form of class struggle, arguing thus the standing to the overall management and control. The article reveals the role of the Republic's MFA as the organizer and coordinator of the operational activities of the Byelorussian SSR in UNESCO, characterizes its interaction with the CPB Central Committee, Committee of the Byelorussian SSR for UNESCO's job and other agencies, as well as with civil society organizations. An extensive factual material that reflects the operations management of the Byelorussian SSR in UNESCO in conjunction with the criteria developed by legal science give reason to designate the Republic as subject of international law, but with limited legal capacity.

\section{Key words}

Belarus; UNESCO; the Khrushchev's Thaw; multilateral diplomacy; the MFA of the Byelorussian SSR; the CPSU Central Committee; the CPB Central Committee.

Статья поступила в июне 2015 г.

\section{Рецензенты:}

Шарапо А. В. - доктор исторических наук, профессор кафедры международных отношений факультета международных отношений Белорусского государственного университета;

Решетников С. В. - доктор политических наук, профессор, заведующий кафедрой политологии Белорусского государственного университета. 


\section{ВЗАИМОДЕЙСТВИЕ РЕСПУБЛИКИ БЕЛАРУСЬ С ООН (1991-2015 гг.)}

\section{A. В. Тихомиров}

дочент кафедры международных отношений

факультета международных отношений

Белорусского государственного университета

УДК 327(476)“1991/2015

Отношения Беларуси с Организацией Объединенных Наций $(\mathrm{OOH})$ имеют определенную специфику, обусловленную тем, что в 1945 г. Белорусская ССР выступила в роли соучредителя указанной международной организации, подписав и ратифицировав Устав ООН. В 1958 г. было открыто Представительство БССР при ООН, которое до 1991 г. оставалось одним из немногих дипломатических представительств Советской Белоруссии за рубежом. В 1965 г. Белорусская ССР стала участником Программы развития ООН/ПРООН. В 1974/75 гг. БССР была непостоянным членом Совета Безопасности ООН от группы восточноевропейских стран.

Обретение статуса суверенного и независимого государства на рубеже 1980-1990-х гг. повлекло изменение установок по реализации политики Беларуси в отношении ООН. Необходимость работы в структурах $\mathrm{OOH}$ и связанных с ней специализированных учреждениях (ЮНЕСКО, Всемирная организация здравоохранения (ВОЗ), Продовольственная и сельскохозяйственная организация Организации Объединенных Наций (ФАО), Организация Объединенных Наций по промышленному развитию (ЮНКТАД), Всемирная организация интеллектуальной собственности (ВОИС), Международная организация труда (MOT) и т. д.) не ставилась под сомнение, поскольку соответствующая международная организация рассматривалась в качестве универсального инструмента поддержания сбалансированной системы международных отношений и решения наиболее острых проблем мирового развития.

В выступлении на 46-й сессии Генеральной Ассамблеи ООН 24 сентября 1991 г. министр иностранных дел Республики Беларусь П. Кравченко высказал мнение, что и в новых условиях, когда у республики начинают завязываться и расширяться двусторонние связи, 
значение ООН не станет для нее преходящим. «...Мы с особым вниманием относимся к дальнейшей исторической судьбе этой организации и готовы вместе со всеми продолжать работу над укреплением ее авторитета», - подчеркнул глава белорусского внешнеполитического ведомства [11, с. 284].

Спустя двадцать лет после этого заявления Министерство иностранных дел Республики Беларусь отмечало, что участие Беларуси в работе $\mathrm{OOH}$ и системы ее органов и специализированных организаций и учреждений способствует более эффективному решению задач внешнеполитического обеспечения процессов развития белорусского государства и модернизации национальной экономики. В политическом плане усилия белорусской дипломатии в ООН были направлены на создание благоприятных внешних условий, обеспечивающих национальную безопасность, суверенитет и территориальную целостность Республики Беларусь, а также служащих формированию международного авторитета страны. В экономическом плане белорусская дипломатия ориентировалась на использование потенциала и ресурсов ООН в процессе внутреннего развития Республики Беларусь. Активное сотрудничество с рядом специализированных организаций и учреждений системы ООН, такими как Международная организация труда, Всемирная организация здравоохранения, Управление ООН по наркотикам и преступности (УНП) и другие, по мнению белорусского внешнеполитического ведомства, должно было способствовать решению национальных задач в области гуманитарного и социального развития [1].

В 1990-е гг. Республика Беларусь расширила присутствие в структурах ООН. В частности, она вступила в Международный валютный фонд (МВФ) и Группу Всемирного банка, Международную организацию гражданской авиации, Международную финансовую корпорацию (МФК), возобновила членство во Всемирной организации здравоохранения, получила статус наблюдателя во Всемирной торговой организации (ВТО). В 2003 г. Республика Беларусь присоединилась к Продовольственной и сельскохозяйственной организации ООН. В августе 2014 г. Постоянный представитель Беларуси был аккредитован при Программе ООН по окружающей среде (ЮНЕП).

Интерес к Беларуси проявлялся и со стороны ООН. В сентябре 1992 г. в Минске открылось представительство ООН, которое стало первым представительством подобного рода на пространстве СНГ. 
Открытие представительства ООН поспособствовало организации визитов в Беларусь руководителей агентств ООН, ведущих экспертов и консультантов, проведению совместных мероприятий, распространению информации об ООН в Беларуси. Также до начала 2015 г. в Минске были открыты представительства ВО3, Детского фонда ОOH (ЮНИСЕФ), Управления верховного комиссара ООН по делам беженцев (УВКБ ООН), Группы Всемирного банка.

В апреле 1994 г. состоялся официальный визит в Республику Беларусь Генерального секретаря ООН Б.-Б. Гали. Высокий гость провел ряд встреч с государственными руководителями Беларуси, сделав акцент на вопросах преодоления последствий чернобыльской катастрофы и нераспространения ядерного оружия [18, с. 84].

В первой половине 1990-х гг. белорусские официальные делегации принимали участие в многосторонних форумах, проводившихся под эгидой ООН: Конференции по охране окружающей среды в Риоде-Жанейро (1992 г.), Конференции по правам человека в Вене (1993 г.), Конференции по народонаселению в Каире (1994 г.), Конференции по социальному развитию в Копенгагене (1995 г.).

В октябре 1995 г. участие в юбилейной 50-й сессии Генеральной Ассамблеи ООН принял Президент Республики Беларусь А. Лукашенко. Глава белорусского государства подчеркнул, что Беларусь намерена продолжать сотрудничество с этой международной организацией [14].

В сентябре 2000 г. белорусская делегация высокого уровня приняла участие в Саммите тысячелетия, проведенном под эгидой ООН в Нью-Йорке. Президент Беларуси поставил подпись под Декларацией тысячелетия ООН.

В очередной раз Президент Республики Беларусь появился на трибуне ООН в сентябре 2005 г. (присутствие в ООН было связано с очередным юбилеем организации). В выступлении на специальном пленарном заседании 60-й сессии Генеральной Ассамблеи ООН он призвал другие государства - члены ООН осознать, что многообразие путей к прогрессу и уважение свободы выбора путей развития являяется непреходящей ценностью современной цивилизации. «Если мы согласимся друг с другом в этом, главном, то мы воплотим принципы многополярности, многообразия, свободы выбора и в реальной жизни, и в документах $\mathrm{OOH}$, которыми мы должны руководствоваться. Мы защитим мир от терроризма, а слабых, женщин и детей - от раб- 
ства. Мы возьмем под защиту всех беззащитных. Тогда и ООН станет организацией по-настоящему объединенных наций», - подчеркнул А. Лукашенко [9, с. 546].

Помимо президента белорусские делегации на сессиях Генеральной Ассамблеи ООН в 1992-2014 гг. возглавляли руководители правительства и министры иностранных дел, излагавшие официальную позицию Беларуси по важнейшим аспектам мирового развития. Площадка $\mathrm{OOH}$ активно использовалась также для налаживания и развития диалога Республики Беларусь с отдельными государствами - членами ООН. Наиболее плотно в рамках ООН белорусская сторона работала с Россией, Китаем и государствами - участниками Движения неприсоединения.

Неудача постигла Беларусь при попытке избрания непостоянным членом Совета Безопасности ООН от группы восточноевропейских государств. В 1994 г. Беларусь проиграла Чехии, в 2001 г. - Болгарии. В первом случае неудача стала результатом плохой подготовки вопроса белорусскими дипломатами, во втором - следствием напряженности в отношениях Беларуси со странами Запада. В дальнейшем белорусская дипломатия не предпринимала попыток избрания в Совет Безопасности ООН в качестве непостоянного члена, однако представители Беларуси избирались в состав Комиссии по науке и технике в целях развития, Комиссии по социальному развитию, Комиссии по населенным пунктам, Комитета по экономическим, социальным и культурным правам, Исполнительного комитета ПРООН/ЮНФПА, Совета руководителей программы $\mathrm{OOH}$ по окружающей среде и других структур $\mathrm{OOH}$.

В ноябре 2006 г. Республика Беларусь впервые была избрана членом Экономического и социального совета ООН (ЭКОСОС) на 2007-2009 гг. В комментарии Министерства иностранных дел Беларуси отмечалось, что белорусская дипломатия намерена сконцентрировать усилия в ЭКОСОС на продвижении социально-экономических интересов развивающихся государств и государств с переходной экономикой [12].

В октябре 2011 г. Беларусь вновь стала членом ЭКОСОС на 2012-2014 гг.

Белорусская дипломатия поддерживала предложения по реформированию ООН, ее структур и механизмов. Еще в сентябре 1991 г. министр иностранных дел Республики Беларусь П. Кравченко выска- 
зал готовность белорусского государства подключиться к консультациям по модернизации ООН [11, с. 284]. В начале XXI в. белорусская сторона предлагала наделить ООН, прежде всего ее главные органы (Генеральная Ассамблея, Совет Безопасности, Экономический и социальный совет) и учреждения, адекватными возможностями для эффективной реализации уставных целей и задач по противодействию глобальным вызовам современности как в политике международной безопасности, так и в социально-экономической сфере [2].

Представители Беларуси подключились к работе Специального комитета по Уставу ООН и усилению роли организации, исходя из того, что деятельность соответствующего органа должна привести к совершенствованию правовых условий функционирования $\mathrm{OOH}$, обеспечить баланс функций и полномочий ее основных органов [7].

Что касается практических аспектов сотрудничества Республики Беларусь с ООН, то оно развивалось по ряду направлений.

Продолжая традиции дипломатии времен БССР, Республика Беларусь придавала большое значение вопросам обеспечения международной безопасности. Еще в 1990 г. Верховный Совет БССР продекларировал намерение отказаться от обладания ядерным оружием.

На практике это намерение было реализовано в первой половине 1990-х гг. В ноябре 1996 г. последняя ракета с ядерной боеголовкой покинула белорусскую территорию. Республика Беларусь стала участником всех основных соглашений в области нераспространения, таких как Договор о нераспространении ядерного оружия (ДНЯО), Договор о всеобъемлющем запрещении ядерных испытаний (ДВЗЯИ), Конвенция о запрещении химического оружия (КЗХО), Конвенция о запрещении биологического и токсинного оружия, ратифицировала Договор о сокращении и ограничении стратегических наступательных вооружений (СТАРТ-1) и Лиссабонский протокол к этому договору. В 1995 г. она подписала Соглашение о гарантиях с МАГАТЭ, в 1996 г. разработала Государственную систему по учету, контролю и физической защите ядерного материала, в 2000 г. вошла в состав Группы ядерных поставщиков.

Решительный и бесповоротный отказ от обладания ядерным оружием позволил нашей стране летом 1996 г. выступить с инициативой о создании в Центральной и Восточной Европе пространства, свободного от ядерного оружия. В декабре 1998 г. 53-я сессия Генеральной Ассамблеи ООН, несмотря на сопротивление ряда госу- 
дарств - членов НАТО, приняла резолюцию «Региональное разоружение», одобрив белорусскую инициативу в области ядерного разоружения.

Беларусь выступала в поддержку идеи о разработке и принятии Программы действий ООН по предотвращению и искоренению незаконной торговли легким оружием и стрелковыми вооружениями (ЛСО) во всех ее аспектах и борьбе с ней. Соответствующая программа была одобрена в июле 2001 г. на Конференции ООН по незаконной торговле ЛСО во всех ее аспектах (конференция состоялась в Нью-Йорке). В январе 2010 г. Беларусь председательствовала на Конференции по разоружению в Женеве.

В 2003 г. Республика Беларусь присоединилась к операциям ООН по поддержанию мира, внеся необходимые коррективы в национальное законодательство. В 2009 г. белорусские военнослужащие (офицер штаба и два врача медицинского госпиталя) впервые были включены в состав Сил ООН по поддержанию мира в Ливане. Международно-правовой статус белорусских миротворцев, условия их пребывания в Ливане и предоставление Республикой Беларусь персонала, имущества и услуг в распоряжение миссии ООН были определены в Меморандуме о взаимопонимании между ООН и правительством Беларуси, который был подписан в Минске 9 августа 2011 г. и ратифицирован Национальным собранием Республики Беларусь в июне 2012 г.

Принимая во внимание рост угрозы международного терроризма, Республика Беларусь после 2001 г. присоединилась ко всем 12 существующим конвенциям и протоколам по вопросам борьбы с терроризмом, принятым под эгидой ООН, и наладила конструктивное взаимодействие с Контртеррористическим комитетом Совета Безопасности ООН. Важным компонентом борьбы с международным терроризмом белорусская дипломатия считала установление прочной системы пограничного и таможенного контроля с целью предотвращения незаконных перевозок через государственную границу оружия и боеприпасов, нелегальной миграции, оборота наркотиков и прочей деятельности, связанной с терроризмом.

Не менее важными с точки зрения белорусской дипломатии являлись вопросы развития. На 48-й сессии Генеральной Ассамблеи ООН в 1993 г. белорусская делегация призывала оказать помощь странам, избавившимся от тоталитарных режимов, и стала соавтором 
резолюций «Интеграция стран с переходной экономикой в мировое хозяйство» и «Предпринимательство и приватизация в интересах экономического роста и устойчивого развития».

В 1997 г. по инициативе белорусского руководства в Минске состоялась Международная конференция по устойчивому развитию стран с переходной экономикой. В подготовке и проведении конференции активное участие приняли Секретариат ООН, ПРООН, Программа ООН по окружающей среде. Главным результатом конференции стало принятие Заключительного документа, в котором впервые на международном уровне определялись перспективы устойчивого развития стран с переходной экономикой.

В 2001 г. Республика Беларусь была избрана в состав Комиссии ООН по устойчивому развитию, в августе - сентябре 2002 г. приняла участие во Всемирном саммите по устойчивому развитию в Йоханнесбурге (ЮАР), поддержав его итоговые документы: Политическую декларацию и План исполнения решений. По инициативе Беларуси в План исполнения решений был внесен пункт о необходимости оказания помощи странам, ставшим жертвами крупных техногенных катастроф. Белорусская делегация также призвала участников встречи обеспечить равноправную интеграцию стран с переходной экономикой в мировое хозяйство.

В декабре 2003 г. Президент Республики Беларусь А. Лукашенко принял участие во Всемирном саммите по информационному обществу в Женеве, где от имени белорусского государства выразил готовность предложить другим странам свои услуги в решении сложных расчетных задач, мониторинге радиационной безопасности, охране окружающей среды и заинтересованность в получении доступа к мировым информационным ресурсам посредством вхождения в глобальную информационную сеть интеллектуальной собственности [9, c. 335].

В июне 2009 г. в Нью-Йорке по инициативе Беларуси состоялся тематический диалог Генеральной Ассамблеи ООН по энергоэффективности, энергосбережению, новым и возобновляемым источникам энергии. Белорусские представители предлагали создать глобальный механизм обеспечения доступа всех стран к технологиям производства и использования новых и возобновляемых источников энергии. К таким мероприятиям были отнесены подготовка Генеральной Ассамблеей ООН рекомендаций о возможностях содействия разработке, 
внедрению и передаче передовых энергетических технологий, создание базы данных передовых энергетических технологий, учреждение под эгидой ООН многостороннего фонда и международного центра передачи передовых энергетических технологий [10, с. 324].

При содействии МФК в Беларуси осуществлялись проекты по поддержке частного предпринимательства и развитию малого и среднего бизнеса, при содействии МОТ - проекты по определению стратегий занятости, повышению социальной защиты граждан и пенсионной реформе, усилению трипартизма и развитию социального диалога, при содействии ЮНКТАД проводились мероприятия по привлечению инвестиций в белорусскую экономику и присоединению Беларуси к ВТО. С помощью ЮНИСЕФ Республика Беларусь адаптировала национальное законодательство к стандартам Конвенции о правах ребенка, осуществляла мероприятия в части развития системы детского здравоохранения и профилактики ВИЧ/СПИДа, защиты наиболее уязвимых групп детей (инвалиды, сироты, молодые правонарушители и др.). При содействии УВКБ ООН осуществлялись мероприятия по интеграции беженцев в белорусское общество.

По линии ЮНФПА Республика Беларусь получала поддержку в области обеспечения гендерного равенства и репродуктивного здоровья, разработки национальной демографической политики. Указанная организация оказывала содействие Беларуси в проведении переписей населения в 1999 и 2009 гг.

Учреждения и организации ООН не только делились с Республикой Беларусь ценным опытом, но и предоставляли конкретные денежные средства, необходимые для развития. В частности, в 1993 и 1995 гг. МВФ предоставил белорусской стороне кредитные ресурсы на сумму около 176 млн долл., в 2009-2010 гг. - на сумму около 3,5 млрд долл. [5, с. 12]. Предоставленные кредиты были направлены на поддержание платежного баланса страны. В рамках взаимодействия с Группой Всемирного банка Беларусь осуществляла проекты в области повышения энергоэффективности, развития систем водоснабжения и водоотведения, обращения с твердыми бытовыми отходами, усовершенствования транспортных путей. 6 июня 2013 г. Совет исполнительных директоров Всемирного банка принял Стратегию партнерства Группы Всемирного банка для Республики Беларусь на 2014-2017 финансовые годы, предполагавшую выделение 380 млн долл. Международным банком реконструкции и развития и 140 млн 
долл. Международной финансовой корпорацией на реализацию проектов в Беларуси [6].

В 2015 г. в число приоритетных направлений сотрудничества по линии Группы Всемирного банка предполагалось включить проекты в области управления государственными финансами, поддержки развития частного сектора, малого и среднего бизнеса, повышения эффективности государственных услуг в сфере образования [6].

В обнародованном в 2010 г. втором национальном отчете «Достижение целей в области развития, сформулированных в Декларации тысячелетия», отмечалось, что Республика Беларусь достигла почти всех Целей развития тысячелетия [4, с. 8].

В октябре 2010 г. в Нью-Йорке была подписана первая Рамочная программа по оказанию помощи в целях развития для Республики Беларусь на 2011-2015 гг. Исходя из приоритетов и потребностей Беларуси во внешнем техническом содействии, а также компетенции специализированных агентств системы ООН, в документе было выделено пять областей сотрудничества:

- содействие устойчивому социально-экономическому развитию;

- содействие укреплению национальной системы здравоохранения;

- содействие обеспечению экологической устойчивости;

- содействие развитию национальной системы управления миграцией в соответствии с международными стандартами;

- содействие совершенствованию государственного управления.

Для реализации Рамочной программы планировалось привлечь более 490 млн долл. [10, с. 476].

Продолжалось активное сотрудничество Беларуси с Программой развития ООН/ПРООН. В ноябре 1991 г. Республика Беларусь обратилась к ПРООН с просьбой придать ей статус страны - реципиента технической помощи в целях развития. Удовлетворение этой просьбы позволяло уменьшить размер членских взносов Белорусского государства в бюджет ООН.

24 сентября 1992 г. между правительством Беларуси и Программой развития ООН было подписано соглашение о сотрудничестве, на основе которого стали разрабатываться страновые программы, направленные на реализацию проектов сотрудничества (к 2015 г. в Беларуси были реализованы четыре страновые программы ПРООН). 
За первые десять лет сотрудничества Республики Беларусь с ПРООН общая стоимость проектов, осуществленных Программой развития $\mathrm{OOH} \mathrm{в} \mathrm{нашей} \mathrm{стране,} \mathrm{превысила} 10$ млн долл. [5, с. 5]. По состоянию на сентябрь 2002 г. в Беларуси были завершены 36 проектов ПРООН, а еще 17 проектов находились на стадии осуществления $[5$, c. 5].

В сентябре 2010 г. Исполнительный совет Программы развития $\mathrm{OOH}$ (ПРООН) /Фонда ООН по народонаселению (ЮНФПА) утвердил четвертую страновую программу, которая предусматривала предоставление Беларуси помощи в таких областях, как экономическое развитие и социальная защита, укрепление инвестиционного потенциала страны, энергосбережение и охрана окружающей среды, преодоление последствий аварии на Чернобыльской АЭС, борьба с ВИЧ/СПИД. Значительное внимание уделялось эффективному государственному управлению, безопасности человека, развитию территорий, проблематике малых и средних городов, созданию стимулов для развития предпринимательства. По сравнению с предыдущей программой размер помощи Беларуси из регулярных и вспомогательных ресурсов ПРООН увеличивался на $10 \%$ и составлял 81,5 млн долл. [10, с. 449].

В ряде случаев белорусская сторона выступала с конкретными инициативами по налаживанию сотрудничества в гуманитарной сфере на глобальном уровне. В сентябре 2005 г. президент Беларуси на 60-й сессии Генеральной Ассамблеи ООН озвучил инициативу об активизации противодействия торговле людьми. Эта инициатива была поддержана структурами $\mathrm{OOH}$ и зарубежными государствами. С подачи Беларуси в 2006 и 2009 гг. Третий комитет Генеральной Ассамблеи ООН принимал резолюции, предусматривавшие совершенствование механизмов борьбы с торговлей людьми. В июле 2010 г. по инициативе Беларуси Генеральная Ассамблея одобрила Глобальный план действий по борьбе с торговлей людьми.

В 2014 г. белорусская дипломатия в ООН предложила усилить работу по поддержке традиционных семейных ценностей. В начале 2015 г. по инициативе Беларуси и Катара в ООН была создана Группа друзей семьи.

Значительные усилия белорусская дипломатия в $\mathrm{OOH}$ прилагала в части мобилизации международной поддержки на устранение последствий техногенной катастрофы на Чернобыльской АЭС, жертвой 
которой Беларусь стала в 1986 г. Первоочередные проекты по смягчению последствий этой катастрофы были утверждены еще на 45-й сессии Генеральной Ассамблеи ООН в 1990 г. Предполагалось, что Беларусь получит 646 млн долл., хотя до начала 1995 г. ООН смогла найти средства на реализацию лишь отдельных программ в объеме 10 млн долл. [13]. В 1997 г. по инициативе правительств Беларуси, России и Украины ООН разработала «Межучрежденческую программу международного содействия территориям, потерпевшим в результате чернобыльской катастрофы». Из 29 проектов, которые предусматривались программой и получили поддержку экспертов, 13 касались Беларуси. На реализацию программы было ассигновано около 1,5 млн долл. [17]. В 1999 г. в Беларуси при поддержке МАГАТЭ осуществлялась реализация 6 проектов на сумму свыше 1 млн долл., наиболее значительным из которых был проект «Реабилитация территорий, пострадавших от чернобыльской катастрофы» [3].

В апреле 2006 г. ООН оказала содействие проведению в Минске международной конференции «Чернобыль спустя 20 лет. Стратегия восстановления и устойчивого развития районов, ставших жертвами аварии».

В том же году Генеральная Ассамблея ООН в специальной резолюции 62/9 провозгласила 2006-2016 гг. десятилетием возрождения и устойчивого развития регионов, пострадавших от последствий аварии на Чернобыльской АЭС.

19 ноября 2007 г. Генеральная Ассамблея ООН единогласно приняла резолюцию «Усиление международного сотрудничества и координация усилий в деле изучения, смягчения и минимизации последствий чернобыльской катастрофы», предложенную Беларусью, Россией и Украиной. При активном участии МАГАТЭ Беларусь внедрила технологии, позволяющие производить в загрязненных районах чистую продукцию одновременно с реабилитацией сельскохозяйственных угодий, а также эффективные средства для обеспечения национальных нормативов по содержанию радионуклидов в продуктах питания и древесине.

Весьма успешным было сотрудничество Беларуси с ЮНЕСКО. В сентябре 1998 г. ЮНЕСКО подписала с Республикой Беларусь Меморандум о сотрудничестве и оказывала значительную помощь нашей стране в деле сохранения традиционной культуры, языка, фольклора, культурных и исторических памятников, расширения интерне- 
та. В список Всемирного наследия ЮНЕСКО были внесены Беловежская пуща, Мирский замок, Несвижский дворцово-парковый комплекс, дуга Струве. ЮНЕСКО стала первой международной организацией, которая помогала Беларуси преодолевать последствия чернобыльской катастрофы. Беларусь трижды избиралась членом Исполнительного совета Организации (в 2000-2001, 2002-2005, 20092013 гг.), в 2013 г. она была избрана в состав Межправительственного комитета по охране и поощрению разнообразия форм культурного самовыражения.

Наиболее проблемными являлись отношения Республики Беларусь с Комиссией ООН по правам человека (КПЧ), действовавшей до 2006 г., и Советом ООН по правам человека (СПЧ), который начал функционировать с 2006 г.

В начале 1990-х гг. Беларусь стала участницей большинства международных инструментов по правам человека, в том числе 6 основных правозащитных договоров: Международного пакта о гражданских и политических правах, Международного пакта об экономических, социальных и культурных правах, Международной конвенции о ликвидации расовой дискриминации, Конвенции о ликвидации всех форм дискриминации в отношении женщин, Конвенции против пыток и других жестоких, бесчеловечных или унижающих достоинство видов обращения и наказания, Конвенции о правах ребенка. Однако во второй половине 1990-х гг. в отношениях Беларуси с указанными структурами ООН возникли проблемы. КПЧ и СПЧ неоднократно критиковали белорусское правительство за нарушения прав человека, отступление от стандартов демократии, ущемление прав негосударственных организаций. Резкая критика звучала в $\mathrm{OOH}$ в связи с сохранением в белорусском государстве смертной казни (соответствующая установка получила одобрение на референдуме, проведенном в Республике Беларусь в 1996 г.).

В 2004 г. Комиссия по правам человека ООН учредила пост спецдокладчика по правам человека в Беларуси. В 2007 г. Совет по правам человека в ООН ликвидировал этот пост, но в 2012 г. мандат спецдокладчика по правам человека в Беларуси был восстановлен.

Решить проблемные вопросы не удалось и в 2000-х гг. В частности, в резолюции 26/25, принятой СПЧ 27 июня 2014 г., отмечалось, что нарушения прав человека в Беларуси носят системный и систематический характер [8]. 
Официальный Минск отвергал предъявляемые ему обвинения. В ноябре 2004 г. белорусская дипломатия на сессии Генеральной Ассамблеи $\mathrm{OOH}$ добилась отклонения проекта совместной резолюции США и ЕС «Ситуация с правами человека в Беларуси» [9, с. 463]. На сегменте высокого уровня 28-й сессии СПЧ 5 марта 2015 г. Постоянный представитель Республики Беларусь при ООН и других международных организациях в Женеве М. Хвостов обвинил СПЧ в отходе от универсально согласованных обязательств в области прав человека и призвал страны Запада вернуться к строгому соблюдению базовых принципов деятельности СПЧ, таких как взаимоуважительный диалог, расширение международного сотрудничества и укрепление потенциала государств в реализации всего комплекса прав человека [15].

В 2010 г. белорусская сторона согласилась пройти первый цикл Универсального периодического обзора (УПО) в СПЧ. Из 93 высказанных в процессе УПО рекомендаций Беларусь приняла 74, которые касались поощрения и защиты экономических и социальных, гражданских и политических прав, а также прав женщин, детей, инвалидов, беженцев и мигрантов [16]. Второй цикл УПО Республика Беларусь должна пройти в 2015 г.

Подводя итог, можно отметить, что взаимодействие с ООН входило в число важнейших приоритетов внешней политики Республики Беларусь с момента ее выхода на международную арену в качестве независимого государства. Деятельность Республики Беларусь в ООН была направлена на расширение контактов с другими государствами - членами $\mathrm{OOH}$, укрепление международных механизмов разоружения и обеспечения безопасности, обеспечение экономического и социального прогресса народов, решение глобальных гуманитарных проблем.

Белорусская сторона использовала рекомендации ООН и связанных с ней международных структур (ЭКОСОС, ЮНИДО, ВОИС, МАГАТЭ, ЮНЕСКО, МОМ, ЮНИСЕФ, СПЧ и др.) при реализации внутренней и внешней политики и делилась накопленным опытом в области развития с другими странами мира. В ряде случаев Беларусь получала по линии ООН конкретную финансовую и организационную поддержку, необходимую для решения социальных, экологических и культурных проблем и ускорения темпов развития. Таким образом, есть основания утверждать, что взаимодействие с $\mathrm{OOH}$ не 
просто формально повышает статус Беларуси на международной арене, но и приносит реальную пользу. Данное направление многостороннего сотрудничества сохранит свою значимость для нашей страны и в перспективе.

\section{Библиографические ссылки}

1. Беларусь и ООН : цели и задачи // М-во иностр. дел Респ. Беларусь [Электронный реcypc]. - URL : http://mfa.gov.by/mulateral/organization/list/bd3cd20f359628d7.html (дата обращения : 18.02.2015).

2. Беларусь и реформа ООН // М-во иностр. дел Респ. Беларусь [Электронный ресурс]. URL : http://mfa.gov.by/mulateral/organization/list/un/db41d8fbd2106c7f.html (дата обращения : 18.02.2015).

3. Краткий обзор событий // Белорусский рынок. - 1999. - № 23. - С. 2.

4. На пути к достижению Целей развития тысячелетия // Бюллетень ООН. - 2010. - № 4.

5. Хортон М. 10 лет МВФ в Беларуси // Бюллетень ООН : спец. вып. - 2002. - № 4.

6. Всемирный банк // М-во иностр. дел Респ. Беларусь [Электронный ресурс]. - URL : http://mfa.gov.by/mulateral/organization/list/fe49ee455f80dca4.html (дата обращения : 18.02.2015).

7. Выступление заместителя начальника главного договорно-правового управления МИД Беларуси Людмилы Татаринович в рамках обсуждения Доклада Специального комитета по Уставу ООН и усилению роли Организации, г. Нью-Йорк, 21 октября 2013 г. // М-во иностр. дел Респ. Беларусь [Электронный ресурс]. - URL : http://www.mfa.gov.by/press/ statements/ba6821a80eb36a98.html (дата обращения : 20.02.2015).

8. Доклад специального докладчика по вопросу о положении в области прав человека в Беларуси, 12 августа 2014 г. // Official Documents System of the United Nations [Электронный pecypc]. - URL : http://daccess-dds-ny.un.org/doc/UNDOC/GEN/N14/502/92/PDF/N1450292. pdf?OpenElement (дата обращения : 20.04.2015).

9. Знешняя палітыка Беларусі : зб. дакл. і матэрыялаў. Т. 9 (2001-2005 гг.) / склад.: У. Е. Снапкоўскі, А. В. Ціхаміраў, А. В. Шарапа ; рэдкал.: С. М. Мартынаў (старш.) [і інш.]. Мінск : БДУ, 2013.

10. Знешняя палітыка Беларусі : зб. дакл. і матэрыялаў / склад. : У. Е. Снапкоўскі [i інш.]; рэдкал.: С. М. Мартынаў (старш.) [і інш.]. - Т. 10 (2006-2010 гг.). - Мінск : БДУ, 2014.

11. Кравченко П. Беларусь на переломе : дипломатический прорыв в мир : выступ., ст., интервью, беседы, дипломат. докл. и переписка : учеб.-метод. пособие. - Минск : БИП-С Плюс, 2009.

12. Материалы брифинга начальника управления информации - пресс-секретаря МИД Андрея Попова, проведенного для представителей СМИ 9 ноября 2006 года // М-во иностр. дел Респ. Беларусь [Электронный ресурc]. - URL : http://mfa.gov.by/press/news_mfa/a170471 d37d33689.htm (дата обращения : 22.06.2015).

13. Смоляр И. Беларусь и мировое сообщество после чернобыльской катастрофы // Нар. газета. $-1995 .-24$ лют.

14. «Мы не можам згадзіцца з тымі, хто ставіць пад сумненне ролю ААН у будучым свеце» : выступ. Прэзідэнта Рэсп. Беларусь А. Р. Лукашэнкі на спец. урачыстым пасяджэнні ГА ААН, прысвеч. 50-й гадавіне ААН // Нар. газета. - 1995. - 24 кастр. 
15. О выступлении Беларуси на сегменте высокого уровня 28-й сессии СПЧ, 6 марта 2015 г. // M-во иностр. дел Респ. Беларусь [Электронный ресурс]. - URL : http://mfa.gov. by/press/news_mfa/a069cf176c45ec56.html (дата обращения : 12.03.2015).

16. Права человека // M-во иностр. дел Респ. Беларусь [Электронный ресурс]. - URL : http://mfa.gov.by/mulateral/human_rights/c1664d7475555e12.html (дата обращения : 18.02.2015).

17. Антонович И. «Продвижение интересов Беларуси на мировой арене - главная суть нашей внешней политики» // Рэспубліка. - 1998. - 25 лістап.

18. Улахович В. Е. Формирование основ внешней политики Республики Беларусь (19912005 гг.). - Минск : Харвест, 2009.

\section{Взаимодействие Республики Беларусь с ООН (1991-2015 г2.) (Алек- сандр Тихомиров)}

В статье раскрываются приоритетные направления и особенности взаимодействия Республики Беларусь с Организацией Объединенных Наций в 1991-2015 гг. Отмечено, что взаимодействие с ООН являлось важнейшим элементом многостороннего сотрудничества Беларуси после обретения ею в 1991 г. статуса независимого государства. Членство в ООН не только повышало статус белорусского государства на международной арене, но и приносило реальную пользу при реализации конкретных проектов в области развития.

\section{Ключевые слова}

Республика Беларусь; ООН; внешняя политика; многостороннее сотрудничество; международные организации; безопасность; развитие; права человека.

\section{Interaction of the Republic of Belarus with the United Nations (1991- 2015) (Aliaksandr Tsikhamirau)}

The article describes the priorities and interaction peculiarities between the Republic of Belarus and the United Nations in 1991-2015. It is noted that cooperation with the UN is the most important element of multilateral cooperation of Belarus after it gained the status of an independent state in 1991. UN membership not only enhanced the status of the Belarusian state in the international arena, but also brought real benefits to the implementation of specific development projects. 


\section{Key words}

The Republic of Belarus; the United Nations; foreign policy; multilateral cooperation; international organizations; security; development; human rights.

Статья поступила в июне 2015 г.

\section{Рецензенты:}

Селиванов А. В. - кандидат исторических наук, заместитель декана факультета международных отношений Белорусского государственного университета;

Есин Р. О. - доктор политических наук, профессор кафедры международных отношений Академии управления при Президенте Республики Беларусь. 


\section{ОСНОВНЫЕ ПРИОРИТЕТЫ ВНЕШНЕЙ ПОЛИТИКИ}

\section{ИСЛАМСКОЙ РЕСПУБЛИКИ ИРАН ПОСЛЕ ЗАКЛЮЧЕНИЯ \\ СОГЛАШЕНИЯ ПО ЯДЕРНОЙ ПРОГРАММЕ}

\section{Ш. Х. Толибова}

второй секретарь управления Африки и Ближнего Востока

МИД Республики Беларусь

УДК 327(55)

В настоящее время в Ближневосточном регионе происходят процессы, которые могут привести к серьезным геополитическим изменениям в мире. В результате завершившихся в Вене 14 июля 2015 г. многолетних переговоров «шестерки» международных посредников (США, Россия, Китай, Великобритания, Франция, Германия) с иранской стороной и достижения договоренности по иранской ядерной программе на мировой арене появился новый «старый игрок» - Исламская Республика Иран, который в перспективе может стать серьезным конкурентом для большинства развитых государств мира и внести ощутимые изменения в систему региональных и международных отношений.

Цель данной статьи - определение приоритетных направлений внешней политики Ирана после заключения соглашения по иранской ядерной программе. Актуальность исследования объясняется тем, что Ирану отводится важная роль в разрешении сложной ситуации в Ближневосточном регионе. Происходящие там события (активизация деятельности террористической группировки «Исламское государство» (далее - ИГ), миграция беженцев из арабских стран в Европу, бесконтрольная добыча нефти террористическими группировками и пр.) могут оказать влияние на военно-политическую и экономическую ситуацию в ряде государств мира.

Для раскрытия поставленной цели в статье будут рассмотрены основные факторы, которые оказывают влияние на внешнюю политику Ирана, определены приоритетные направления внешней политики этой страны, а также инструменты ее реализации.

При написании статьи были использованы новостные сообщения СМИ, официальные интернет-ресурсы иранских религиозных и политических деятелей, работы зарубежных исследователей. 
Иран - страна с древнейшей цивилизацией, богатейшей культурой и народом, который гордится своей «великой историей сверхдержавы». Именно мысль о величии персидского народа в сознании каждого иранца служит мощным стимулом для того, чтобы вернуть иранскому народу былую славу и занять достойное место в мировой политике.

Современная внешнеполитическая доктрина Ирана предполагает проведение независимого курса и превращение страны не только в региональную державу, но и в активного субъекта мировой политики. Современная иранская политическая, экономическая и научная элита независимо от социальных настроений поддерживает эти задачи и принимает участие в реализации данной сверхидеи. В иранском обществе в целом наблюдается высокий энтузиазм в части превращения Ирана в великую державу, и средние слои общества выступают носителями этой идеи [9]. Шанс, который появился у Ирана после заключения соглашения по ядерной программе, будет использован этой страной в полной мере. Иранская сторона имеет четкое представление о том, как выстраивать отношения с Европой, Россией, США и другими странами мира.

Одним из основных приоритетов внешней политики Ирана после заключения соглашения по ядерной программе станет налаживание сотрудничества с европейскими странами, с которыми иранская сторона вела тесное торгово-экономическое сотрудничество в шахское время, и, даже несмотря на введенные санкции, это сотрудничество до конца не было прекращено. В частности, верховный представитель ЕС по иностранным делам и политике безопасности Ф. Могерини в статье «Соглашение с Ираном - катастрофа для Исламского государства» отмечает, что европейцы имеют давнюю традицию сотрудничества с Ираном в области культуры и экономики, и напоминает, что интересы Евросоюза не сводятся только к бизнесу, но также включают в себя поиск политического диалога и сотрудничества в области безопасности [16].

Одним из первых шагов, сделанных иранской стороной после достижения ядерного соглашения, стало возобновление дипломатических отношений с Великобританией. Ранее сложилось представление о том, что для Ирана, как выразился аятолла Али Хаменеи, Соединенное Королевство - «главный враг и источник зла» [1]. Более того, многие иранцы убеждены, что США являются инструментом 278 
проводимой Великобританией политики в отношении Ирана. В то же время очевидно, что в настоящее время Ирану намного выгоднее сотрудничать с Великобританией - одним из мировых финансовых центров - для восстановления государственной финансовой системы, а также с целью продвижения своих интересов на Западе и в США.

В реализации внешнеполитического курса на западном направлении Иран, вероятно, будет действовать осмотрительно, с учетом развития ситуации в Ближневосточном регионе. Во-первых, иранские военные неоднократно обвиняли США, Великобританию и Израиль в создании и поддержке террористической организации ИГ, называя их «покровителями группировки». По мнению иранского руководства, их целью может стать контроль над нефтяными месторождениями в Ираке, Сирии, Ливии и в последующем - в Иране. Кроме того, действия США в отношении ИГ укладываются в декларируемую американской элитой стратегию «выстраивания баланса» между различными силами в ближневосточном регионе в собственных интересах [9].

Во-вторых, в последнее время наблюдается активизация взаимодействия правительства Иракского Курдистана с США. Курды, мечтающие в течение десятилетий о создании независимого государства, готовы верить тому, что США искренне оказывают им поддержку для достижения этой цели. В то же время Иран, Турция, Сирия и Ирак страны, которых напрямую касается «курдский вопрос», четко осознают, что, как говорил президент США Р. Рейган, «курды являются той спичкой, которую Америка может зажечь тогда, когда ей будет выгодно» [15]. Не исключено, что осознание этого стало причиной однодневного официального визита президента Турции Р. Эрдогана в Иран в апреле 2015 г. Он стал первым зарубежным лидером, посетившим Иран после прорыва на переговорах по иранской ядерной программе. Для турецкого президента этот визит был непростым, поскольку ранее он выступал с обвинениями в адрес Ирана, заявляя о попытках иранской стороны доминировать на Ближнем Востоке, и требовал вывести поддерживаемые Ираном вооруженные формирования из Сирии, Ирака и Йемена. Однако осознание необходимости объединиться для решения общей «курдской проблемы» стало ключевым фактором в решении турецкой стороны посетить Иран, а иранской стороны - в согласии принять президента Турции с визитом.

По мнению эксперта по проблемам стран Ближнего Востока и Кавказа С. Тарасова, именно Р. Эрдоган предложил Ирану план си279 
рийского и иракского урегулирования, согласно которому Тегеран и Анкара должны выступить посредниками между конфликтующими сторонами, о чем он заявил на совместной пресс-конференции с президентом Ирана Х. Рухани [13].

Проблемность «курдского фактора» для турецкого руководства подтверждается и июльской антитеррористической операцией против сил ИГ, в рамках которой были подвержены бомбардировке позиции Курдской рабочей партии в приграничных районах Сирии и Северного Ирака. Это было сделано невзирая на то, что в настоящее время курды оказывают поддержку силам международной коалиции в борьбе с ИГ.

Иранское руководство периодически проводит переговоры с курдскими лидерами. Различие в подходах Ирана и Турции объясняется тем, что иранская сторона действительно проводит независимую политику. Кроме того, исторически так сложилось, что персы придерживаются принципов, заложенных еще во времена правления персидского царя Кира Великого, - уважения народов, живущих на территории его империи. В связи с этим идеи пантюркизма не имеют успеха среди азербайджанского населения, проживающего в Иране. Иранские азербайджанцы чувствуют себя в Иране равными среди равных.

Иранское руководство осознает, что эти факторы могут быть использованы соответствующими силами для давления на Иран. В связи с этим в ходе выступления в августе 2015 г. на встрече с участниками 8-го саммита Генеральной ассамблеи Исламского радио- и телевизионного союза и 6-й Генеральной ассамблеи Всемирной шиитской ассамблеи Ахли-Бейт в Тегеране аятолла Али Хаменеи подчеркнул, что Исламская Республика ни под каким предлогом не позволит США вторгаться в страну [17]. Причем уверенность в словах главы иранского государства вполне объяснима. Следует отметить хорошо слаженную работу спецслужб Ирана, основа которых была заложена во времена правления шаха Мохаммеда Резы Пехлеви в 1950-е гг., а затем разветвлена благодаря структурам иранского шиитского подполья, возникшим в 1960-е гг. в Южном Ираке, Ливане, Египте и США. В настоящее время США приходится рассчитывать только на возможности технической разведки (например, данные, полученные с помощью спутников-шпионов) и информацию, поступающую от перебежчиков. ЦРУ и другие американские разведслуж- 
бы не располагают надежной агентурой в Иране. Все попытки проведения разведопераций на территории этой страны заканчивались и заканчиваются провалом [3].

Даже израильские спецслужбы, которые считаются самыми сильными в регионе, испытывают серьезные трудности в организации эффективной разведывательной деятельности на территории Ирана. С момента вербовки и обучения агента израильской разведкой «Моссадом» до его задержания иранскими спецслужбами, как правило, проходит не больше года, и редко кому удается проработать два или три года [3].

С учетом налаживания Ираном дипломатического и торговоэкономического взаимодействия со странами Запада, а также контактов с США следует ожидать активизации деятельности иранских разведслужб, в первую очередь в США и Европе, где сегодня спецслужбы этой страны имеют мощную резидентуру.

Кроме того, в последнее время наблюдается активное взаимодействие Ирана с Россией. История ирано-российских отношений сложна и неоднозначна. Многие иранцы до сих пор помнят вторжение, фактический раздел и оккупацию территории Ирана советскими и британскими войсками в период Второй мировой войны. Вместе с тем в настоящее время в развитии ирано-российского сотрудничества заинтересован как Иран, так и Россия. С одной стороны, они являются странами-соседями, и их сотрудничество обеспечивает соответствующую защиту общей границы - Каспия. С другой - взаимная поддержка позволяет им сохранять свои стратегические позиции на Ближнем Востоке, в Средней Азии и на Кавказе. Подтверждением этому служит заявление глав внешнеполитических ведомств Ирана и России, сделанное в ходе состоявшейся в Москве в августе 2015 г. встречи, о близости подходов двух стран в отношении стабилизации обстановки на Ближнем Востоке, что позволит эффективнее координировать усилия сторон в целях содействия урегулированию конфликтов в Ираке, Сирии и Йемене, а также усилить совместную борьбу против террористической угрозы, исходящей от «Исламского государства» и других экстремистских группировок [6].

Особый интерес представляет ирано-российское военнотехническое сотрудничество, которое в последнее время начало активно развиваться. Перспективы этого сотрудничества определяются не только внутренней мотивацией сторон продвинуть свои отноше- 
ния на качественно иной уровень. Как уже было отмечено, существует ряд глобальных и региональных факторов, подталкивающих Москву и Тегеран к крепким военно-политическим связям и развитию отношений в сфере военно-технического сотрудничества. Украинский кризис сделал Москву менее расположенной к учету «особого мнения» западных и некоторых ближневосточных столиц относительно продажи Тегерану современных военных систем. Международно-правовые ограничения в данном вопросе в виде известных резолюций Совета Безопасности ООН сохраняют свое сдерживающее влияние на российскую сторону, но внешнеполитическая мотивация преодолеть эти препоны на пути к восстановлению масштабного военно-технического сотрудничества с Тегераном у Москвы значительно выросла. Две крупнейшие державы Каспия оказались под схожим прессом Запада, что задает свою логику совместных действий в деле нейтрализации этого давления со стороны евроантлантического блока. Свою особую роль, несомненно, призван сыграть и фактор воинствующего джихадизма на Ближнем Востоке, тесное вовлечение Ирана в противостояние с террористической группировкой «Исламское государство» в Ираке [11].

В свою очередь, очевидным становится то, что Россия и США в настоящее время особенно заинтересованы в сближении с Ираном для достижения своих геополитических интересов. Это связано не только с интересами России и США в Ближневосточном регионе, но и с ситуацией в Украине. В частности, США намерены со всех сторон окружить Россию своими союзниками, чтоб при необходимости оказать соответствующее давление на нее. Однако не стоит забывать, что саму иранскую сторону всегда беспокоила возможность размещения, в том числе на территории Польши, американских военных баз, системы ПРО, которые могут быть использованы в войне против него. Поэтому полагать, что Иран станет сближаться с США, преждевременно. Очевидно, что иранская сторона стремится получить максимальную выгоду из противостояния России и США в сложившихся условиях.

Еще одним значимым партнером Ирана становится Китай. В основе сотрудничества этих двух стран заложен прагматизм. Китай в отношениях США к Ирану рассматривает откровенное стремление американцев обеспечить свое стратегическое доминирование и добиться контроля над богатейшими углеводородными ресурсами Ира- 
на. Зависимость Китая от импорта нефти превышает 50 \%, причем от 11 до 14 \% нефти ввозится из Ирана [2].

Китайская сторона осознает, что после подписания ядерного соглашения у нее появляются серьезные конкуренты, которые могут не только вытеснить китайские компании с иранского нефтяного рынка, но также стать угрозой энергетической безопасности Китая.

Вместе с тем, пока в отношении Ирана не сняты все санкции, он нуждается в поддержке Китая для блокирования возможных антииранских резолюций в Совете Безопасности ООН. Кроме того, в период действия санкций Китаю удалось занять ниши, которые были оставлены европейскими компаниями.

Таким образом, в числе своих стратегических внешнеполитических партнеров руководство Ирана рассматривает Китай, который привлекает иранцев прежде всего как важнейший политический компонент своей азиатской политики, способный содействовать не только укреплению иранской экономики и обороноспособности, но и продвижению иранских интересов на международной арене.

После заключения ядерного соглашения Иран, безусловно, еще больше активизирует свою деятельность в Ближневосточном регионе. По словам аятоллы Али Хаменеи, «Иран будет продолжать поддерживать своих друзей в регионе, включая Палестину, Йемен, Сирию, Бахрейн, и группы сопротивления в Ливане и Палестине» [8].

В целом государства Залива позитивно восприняли заключение соглашения «шестерки» с Ираном. В то же время Саудовская Аравия проявляет свою озабоченность в связи с изменением политического вектора США в отношении Ирана. В сентябре 2015 г. состоялся визит короля Саудовской Аравии в Соединенные Штаты. В ходе встречи президент США Б. Обама и саудовский король Салман обменялись мнениями по ситуации в Йемене и Сирии, а также обсудили меры по противостоянию дестабилизирующей деятельности Тегерана в регионе.

Президент независимого научного центра «Институт Ближнего Востока» Е. Я. Сатановский считает, что «это - сверка часов. Отношения Саудовской Аравии и США после подписания ядерной сделки настолько ухудшились, что в улучшении хотя бы формальном заинтересованы и Эр-Рияд, и Вашингтон. И в данном случае это скорее символический визит» [4]. 
В то же время политический обозреватель, член-корреспондент Парижского центра дипломатических и стратегических исследований А. Мехтиев считает: нынешний визит монарха Саудовской Аравии в Вашингтон стал показателем несоответствия реальности предположений российских экспертов о том, что Эр-Рияд воспринял «ядерную сделку» Запада с Ираном как предательство со стороны Вашингтона. В итоговом заявлении по окончании переговоров короля Салмана с Обамой министр иностранных дел Саудовской Аравии Адель альДжубейр подчеркнул: «Американская сторона заверила нас в том, что условия сделки не позволят Ирану получить ядерное оружие и что предусмотренный механизм инспекций будет эффективен. Также было заявлено, что сделка предусматривает быстрое введение новых санкций в случае, если Иран откажется соблюдать ее условия. Королевство Саудовская Аравия после двух месяцев консультаций с союзниками заявляет, что удовлетворено этими заверениями».

Американский эксперт Г. Ховард, который возглавляет Вашингтонский аналитический центр Джеймстаунского фонда, оценивая компромисс по Ирану между Вашингтоном и Эр-Риядом, отмечает: «Саудовская армия бомбит Йемен, и США оказывают многоплановую поддержку военно-воздушным силам Саудовской Аравии. Вашингтон, судя по всему, закроет глаза на то, что происходит в Йемене в обмен на молчаливую поддержку саудитами соглашения с Ираном» [10].

Естественно, США выгодно сталкивать интересы Ирана и Саудовской Аравии - когда лидеры ближневосточного региона заняты решением вопросов друг с другом, другие государства могут вести свои политические игры в регионе и извлекать соответствующие бонусы. Неудивительно, что ситуация в Йемене, где идет столкновение интересов Эр-Рияда и Тегерана, начала ухудшаться параллельно с решением вопроса по ядерной программе Ирана.

Более благополучно складываются отношения Ирана с Оманом, Катаром, Бахрейном. Растет товарооборот, заключаются выгодные торговые и экономические соглашения, увеличивается обмен туристами. Большое количество иранских рабочих размещено в этих странах. Их правительства выступают за расширение отношений с Ираном, за принятие его в арабские сообщества. Но все же существует определенная настороженность со стороны арабов по поводу внешней политики Ирана, еще недавно провозглашавшей активный 
экспорт «иранской революции» в арабские страны. Большинство стран Персидского залива находится под влиянием Саудовской Аравии, которая продолжает сохранять отчужденные отношения с ИраHOM.

Главными союзниками Ирана в арабском мире остаются Сирия и Ливан. Сирия была единственной страной, которая на протяжении всей ирано-иракской войны оказывала политическую и моральную поддержку Ирану. Для Сирии важна та финансовая помощь, которую ей оказывает Иран, и его экономическая и военная поддержка ее позиций в Ливане [14].

Еще одним важным вектором внешней политики Ирана был и останется Среднеазиатский регион. Несмотря на действующие санкции, Ирану за последние несколько лет удалось укрепить свои отношения со странами Средней Азии.

В частности, Иран и Казахстан неоднократно подтверждали политическую волю и заинтересованность в развитии дружественных и добрососедских отношений. Стороны тесно взаимодействуют в рамках региональных и международных организаций. Наблюдается ежегодный рост товарооборота между двумя странами (в 2012 г. 678,9 млн долл., в 2013 г. - 620,5 млн долл., в 2014 г. - 987,1 млн долл. [12]). После отмены санкций представляется логичным дальнейшее развитие сотрудничества между двумя странами. В то же время Казахстан ведет взвешенную политику в отношении Ирана, учитывая, как это может отразиться на его диалоге с Вашингтоном, Евросоюзом или той же Турцией. Именно поэтому Астана была инициатором идеи об изменении регламента вступления в Шанхайскую организацию сотрудничества (ШОС), результатом чего стал пункт о невозможности вступления в нее государства, находящегося под международными санкциями. Ни у кого не возникало сомнений, что это предложение было тем шлагбаумом, который закрыл Тегерану дорогу к полноценному членству в ШОС. Тем самым Казахстан продемонстрировал, что разделяет западную политику «сдерживания Ирана» в регионе и осторожно, но настойчиво выступает в этом вопросе проводником интересов США и ЕС [7].

Иран и Таджикистан, безусловно, заинтересованы в тесном сближении друг с другом с учетом общих историко-культурных ценностей и торгово-экономических и политических интересов. Этим отношениям Тегеран придает особо значение, поскольку рассматри- 
вает Таджикистан как часть персоязычного мира. Иран стремится расширить отношения с Душанбе во всех областях, в том числе в экономической сфере. В Таджикистане работает более 150 иранских фирм, а торговый оборот между двумя странами по итогам 2014 г. составил более 228 млн долл., что составляет 4,3\% общего объема внешнеторгового оборота Душанбе [7]. Иран оказывает помощь Таджикистану в восстановлении страны после гражданской войны. Кроме того, иранская сторона ведет работу по развитию союза Иран Таджикистан - Афганистан на основе подписанного в 2008 г. Соглашения о создании Экономического совета персоязычного союза. Вместе с тем как Таджикистан, так и Афганистан ведут зависимую от России и Америки политику, что обусловлено активной деятельностью и влиянием этих стран. Это обстоятельство является сдерживающим фактором для перехода деятельности «союза троих» в активную фазу.

Отношения Ирана и Туркменистана могут быть с полным правом названы самыми стабильными и динамичными. В немалой степени из-за того, что две страны объединяют общие границы, многовековая историческая и конфессиональная близость. Прочным фундаментом добрососедства служит и наличие на севере Ирана значительного массива туркменского населения.

Отношения двух стран построены и на взаимной выгоде. С 52 тыс. долл. в 1992 г. товарооборот между двумя странами достиг 3,7 млрд в 2014 г. Как заметил иранский президент Х. Рухани, «мы высказали намерение в течение 10 лет довести этот показатель до 60 миллиардов долларов». С помощью Ирана в Туркменистане реализовано или находится на стадии реализации около сотни промышленных объектов, имеющих приоритетное значение для национальной экономики [7].

Состоявшийся в сентябре текущего года визит президента Кыргызстана в Иран подтвердил дружественный характер отношений между двумя странами. По итогам встречи с кыргызским коллегой иранский президент сделал знаковое заявление: «Сегодня Кыргызстан следует независимой политике. Мы наблюдали, что вы закрыли авиабазу американцев в “Манасе". Это говорит о том, что сегодня наши позиции и идеи в международных и региональных вопросах близки. И мы можем наращивать свои отношения в этой области. Также мы должны тесно сотрудничать в области борьбы с насилием и 
терроризмом» [5]. Кроме того, стороны подтвердили намерение развивать взаимовыгодное сотрудничество в торгово-экономической, научно-технической, культурной, гуманитарной и других областях.

Единственная страна в Центральной Азии, с которой наблюдается отрицательная тенденция в развитии отношений у Ирана, - Узбекистан. С момента обретения независимости Ташкент всегда достаточно настороженно относился к расширению иранского присутствия в регионе. Главной причиной подозрительности было то, что это присутствие станет толчком к возрождению в стране таджикского национализма, чреватого увеличением сепаратистских настроений в Бухаре и Самарканде. Кроме того, правящие узбекские политические элиты подозревали Тегеран в намерениях усилить в стране позиции исламских общин, находящихся в оппозиции к светским властям. В немалой степени именно поэтому, когда в 1995 г. американский конгресс ввел против Ирана экономические санкции, Узбекистан стал единственным из постсоветских государств, кто открыто поддержал эту меру [7]. В целом необходимо отметить проамериканскую направленность политики Узбекистана, что отражается на взаимоотношениях с Ираном.

Кроме Средней Азии, Иран будет заинтересован также в продолжении конструктивного диалога с государствами Южного Кавказа - Азербайджаном, Арменией и Грузией. Сегодня азербайджаноиранские отношения находятся на высоком уровне. Обе страны тесно сотрудничают в рамках международных организаций. На официальном уровне отношения двух стран называются «братскими». Несмотря на стремление США оказать влияние на политику Азербайджана в отношении Ирана, азербайджанская сторона в целом сохраняет сдержанную позицию. Страны тесно сотрудничают в различных областях. После заключения соглашения по иранской ядерной программе Азербайджан активизировал свое взаимодействие с Ираном, выступив с инициативными предложениями в нефтегазовой сфере. В отношениях с Грузией Иран придает серьезное значение как политическим планам, так и удовлетворению своих геостратегических и экономических интересов. В июле 2015 г. Иран отменил визы для граждан Азербайджана и Грузии, что свидетельствует о стремлении к двустороннему сближению. Между Ираном и Арменией отношения практически союзнические. Постоянно осуществляются контакты на высоком уров- 
не, развиваются культурные связи, вместе с тем уровень торговоэкономических отношений незначителен для стран-соседей.

Таким образом, достижение соглашения «шестерки» международных посредников с иранской стороной по ядерной программе, а также события, происходящие на Ближнем Востоке, привели к тому, что Иран получил возможность укрепить свой статус не только в этом регионе, но и в мире.

К значимым региональным факторам, которые Иран будет учитывать при проведении внешнеполитического курса после подписания ядерного соглашения, можно отнести деятельность ИГ на Ближнем Востоке и так называемый «курдский фактор», поскольку иранская сторона считает эти два фактора рычагами, которые могут использовать США и Великобритания для оказания давления на Иран в целях достижения собственных интересов в этом регионе.

Основными направлениями внешней политики Ирана после заключения соглашения по ядерной программе станут налаживание прагматического сотрудничества с европейскими странами, укрепление отношений со странами-соседями (Азербайджан, Афганистан, Ирак, Турция, Пакистан, Туркменистан) и оказание им всемерной поддержки.

Особое место во внешнеполитическом курсе Ирана будут занимать Россия и Китай, сотрудничество с которыми все больше приобретает стратегический характер. Неизменной останется позиция иранской стороны в отношении ближневосточных государств (Палестина, Йемен, Сирия, Бахрейн), Центральной Азии и Кавказского региона. Для продвижения своих интересов Иран будет использовать грамотно выстроенный политический диалог, слаженную работу спецслужб с разветвленной структурой во многих странах мира, а также обострившиеся противоречия между Россией и США.

\section{Библиографические ссылки}

1. Аятолла Хаменеи приказал остановить протесты // Новостное агентство ВВС [Электронный pecypc]. - 2009. - URL : http://www.bbc.com/russian/international/2009/06/090618_ iran_speech.shtml (дата обращения : 23.09.2015). 
2. Бобкин H. Иран и Китай: в основе дружественных отношений прагматизм // Новое восточное обозрение. - URL : http://ru.journal-neo.org/2014/02/21/iran-i-kitaj-v-osnovedruzhestvenny-h-otnoshenij-pragmatizm/ (дата обращения : 23.09.2015).

3. Ганиев T. А. Роль и место специальных служб Исламской Республики Иран в реализации внешнеполитических интересов страны // Центр стратегических оценок и прогнозов [Электронный pecypc]. - URL : http://csef.ru/ru/politica-i-geopolitica/484/4208 (дата обращения : 23.09.2015).

4. Горшков О. Проблемы в отношениях Саудовской Аравии и США стоили жизни более сотни солдат // ВЕСТИ.РУ [Электронный ресурс]. - 2015. - URL : http://www.vesti.ru/ doc.html?id=2660737 (дата обращения : 23.09.2015).

5. Жук О. Кыргызстан - Иран: полное понимание // Дело [Электронный ресурс]. - 2015. URL : http://delo.kg/index.php/health-7/8906-kyrgyzstan-iran-polnoe-ponimanie (дата обращения : 23.09.2015).

6. Иран и Россия объединят усилия против ИГ // Иран.ру [Электронный ресурс]. - 2015. URL : http://www.iran.ru/news/politics/98212/Rossiya_i_Iran_obedinyat_usiliya_protiv_IG (дата обращения : 23.09.2015).

7. Иран и Центральная Азия // Иран.ру [Электронный ресурс]. - 2015. - URL : http://www.iran.ru/news/analytics/97576/Iran_i_Centralnaya_Aziya. (дата обращения : 23.09.2015).

8. Иран не поддастся на чрезмерные требования врагов: Верховный Лидер // ИА IRNA [Электронный ресурс]. - 2015. - URL : http://www.irna.ir/ru/ News/2901272/ (дата обращения : 23.09.2015).

9. Иран обвинил США в поставках оружия «Исламскому государству» // Живой журнал [Электронный ресурс]. - URL : http://www.grandit.livejournal. com/302630.html (дата обращения : 23.09.2015).

10. Мехтиев $A$. К итогам визита короля КСА в Вашингтон: существует ли нефтяной сговор против России // Экспертно-информационная интернет-площадка AGAFNEWS [Электронный ресурс]. - 2015. - URL : http://arafnews.ru/news/k-itogam-vizita-korolja-ksa-v-vashingtonsuschestvuet-li-neftjanoj-sgovor-protiv-rossii.html (дата обращения : 23.09.2015).

11. Россия - Иран: проблемы и перспективы военно-технического сотрудничества // ИА ЕurAsiaDayli [Электронный pecypc]. - 2015. - URL : https://eadaily.com/news/2015/06/20/rossiyairan-problemy-i-perspektivy-voenno-tehnicheskogo-sotrudnichestva (дата обращения : 23.09.2015).

12. Сотрудничество Республики Казахстан и Исламской Республики Иран // официальный сайт МИД Республики Казахстан [Электронный ресурс]. - URL : http://mfa.gov.kz/index. $\mathrm{php/ru/vneshnyaya-politika/sotrudnichestvo-kazakhstana/sotrudnichestvo-so-stranami-azii-i-afriki/}$ 84-vneshnyaya-politika/sotrudnichestvo-kazakhstana/sotrudnichestvo-so-stranami-azii-i-afriki/360sotrudnichestvo-respubliki-kazakhstan-s-islamskoj-respublikoj-iran (дата обращения : 23.09.2015).

13. Тарасов С. Эрдоган отправился в Иран за «отпущением грехов» // ИA REGNUM [Электронный ресурс]. - 2015. - URL : http://www.regnum.ru/news/1913255.html (дата обращения : 23.09.2015).

14.Эркимбаев Д. Основные направления внешней политики Ирана // Учебники онлайн [Электронный ресурс]. - URL : http://uchebnik-online.com/131/1123.html (дата обращения : 23.09.2015).

15. Ignatchenko I. Turkey: Taking a Risk With the U.S. In Syria // Аналитический журнал Oriental Review [Электронный ресурс]. - 2012. - URL : http://orientalreview.org/2012/06/07/turkeytaking-a-risk-with-the-u-s-in-syria/ (дата обращения : 23.09.2015). 
16. Mogherini F. The Iran agreement is a disaster for Isis // The Guardian [Электронный pecypc]. - 2015. - URL : http://www.theguardian.com/commentisfree/2015/jul/28/iran-agreementisis-vienna-eu (дата обращения : 23.09.2015).

17. Ba hame tavan ejazee nofuz-u-hozure Amrikaehara dar Iran namidahim (Всеми усилиями не позволим проникновению Америки в Иран) // Информационный блок офиса Великого лидеpa C. А. Хаменеи [Электронный ресурс]. - URL : http://www.leader.ir/langs/fa/index.php? $\mathrm{p}=$ contentShow\&id=13481 (дата обращения : 23.09.2015).

Основные приоритеты внешней политики Исламской Республики Иран после заключения соглашения по ядерной программе (Шобнам Толибова)

В результате завершившихся в Вене 14 июля 2015 г. многолетних переговоров «шестерки» международных посредников (США, Россия, Китай, Великобритания, Франция, Германия) с иранской стороной и достижения договоренности по иранской ядерной программе на мировой арене появился новый «старый игрок» - Исламская Республика Иран, который в перспективе может внести ощутимые изменения в систему региональных и международных отношений.

В статье рассмотрены основные факторы, которые оказывают влияние на внешнюю политику Ирана, определены приоритетные направления внешней политики этой страны после заключения венского соглашения, а также инструменты ее реализации.

Основными направлениями внешней политики Ирана после заключения соглашения по ядерной программе станут налаживание прагматического сотрудничества с европейскими странами, укрепление отношений со странами-соседями и оказание им всемерной поддержки. Особое место во внешнеполитическом курсе Ирана будут занимать Россия и Китай. Неизменной останется позиция иранской стороны в отношении ближневосточных государств (Палестина, Йемен, Сирия, Бахрейн), Центральной Азии и Кавказского региона.

\section{Ключевые слова}

Исламская Республика Иран; иранская ядерная программа; внешняя политика Ирана. 

the conclusion of an agreement on nuclear program (Shabnam Tolibo$v a)$

After long years of negotiations between «six» of international mediators (the US, Russia, China, Britain, France and Germany) and Iranian Side nuclear deal has been signed in Vienna on 14 July 2015. As a result on the world stage appeared a new «Old player» - Islamic Republic of Iran, which can impose significant changes in regional and international relations.

This article describes the main factors that influence to the foreign policy of Iran, priority directions of the foreign policy of this country after signing Vienna agreement, and tools for its implementation.

After the signing of nuclear agreement the main directions of the foreign policy of Iran will be establishment of pragmatic cooperation with European countries, strengthening relations with neighboring countries (supporting them). Russia and China will take a special place in the foreign policy of Iran. Iranian side will not change its position regarding countries of the Middle East (Palestine, Yemen, Syria, Bahrain), Central Asia and the Caucasus region.

\section{Key words}

The Islamic Republic of Iran; the nuclear program of Iran; Iranian foreign policy.

Статья поступила в сентябре 2015 г.

\section{Рецензенты:}

Шевелев Д. Л. - кандидат исторических наук, доцент кафедры международных отношений Белорусского государственного университета;

Есин Р. О. - доктор политических наук, профессор кафедры международных отношений Академии управления при Президенте Республики Беларусь. 


\section{ВНУТРЕННЯЯ ЭНЕРГЕТИЧЕСКАЯ ПОЛИТИКА \\ ЕВРОПЕЙСКОГО СОЮЗА В 2006-2014 ГГ.}

\section{A. М. Чижс}

аспирант кафедры международных отношений

факультета международных отношений

Белорусского государственного университета

УДК 339.97:620.9(4)ЕС

В конце 2014 г. Европейская комиссия во главе с новым председателем Ж.-К. Юнкером поставила перед Европейским союзом масштабную цель по формированию в его рамках энергетического союза. Тем самым ЕС взял курс на углубление интеграции в стратегически важной для каждого государства-члена сфере - в энергетике. Данный союз будет строиться на достижениях в обеспечении энергетической безопасности, которых Брюсселю удалось добиться с 2006 по 2014 г., в наиболее активный период формирования и реализации энергетической политики.

Исследователи все чаще обращаются к проблемам энергетической политики Евросоюза, однако свое внимание они, как правило, акцентируют на ее внешней составляющей.

Энергетическая политика ЕС как комплексная проблема рассматривается в подготовленной международным коллективом авторов работе под редакцией Я. Калицки и Д. Голдвина [25]. Ocoбенности внутреннего энергетического рынка Евросоюза и его влияние на взаимоотношения с государствами вне ЕC анализирует П. Эйкланд [20]. Л. Падалко в своей работе рассматривает перспективы создания газового рынка в Европе [3]. Следует также отметить публикацию И. Гудкова, посвященную юридическим аспектам Третьего энергетического пакета [1]. Что касается сектора возобновляемой энергетики, то ключевые направления его развития в Европейском союзе подробно анализирует П. Каныгин, работа которого вызывает особый интерес [2].

Актуальность темы энергетической политики ЕС обусловлена не только общей обеспокоенностью стран мира проблемами энергетической безопасности, но и той ролью, которую вопросы энергетики играют в отношениях между Евросоюзом и его соседями. Необходи- 
мость удовлетворения потребностей в энергоресурсах и энергии подталкивает к формированию региональных энергетических рынков и реализации совместных проектов в сфере возобновляемых источников энергии (далее - ВИЭ) и энергоэффективности. Подобные вопросы могут появиться и в повестке дня Республики Беларусь. Поэтому следует изучить опыт ЕС в данной сфере, чтобы выявить потенциальные препятствия и определить оптимальные пути укрепления энергетической безопасности.

Таким образом, цель настоящей статьи - проанализировать ключевые направления энергетической политики Европейского союза в 2006-2014 гг. на основе систематизации документов и новых статистических данных.

В 2006-2014 гг. ЕС предпринимал шаги по созданию единого энергетического рынка ${ }^{*}$, развитию возобновляемой энергетики и внедрению энергоэффективных технологий. При этом на внутреннем направлении ключевая задача Брюсселя заключалась в формировании единого полноценного энергетического рынка, который в соответствии с решениями Европейского совета от 4 февраля 2011 г. должен был начать функционировать с 1 января 2015 г. [12].

Уже в 1990-х гг. целью процесса либерализации рынков электроэнергии и природного газа были не только демонополизация энергетических рынков ЕС и обеспечение прозрачных и справедливых тарифов на электроэнергию и газ. Одновременно ставилась задача модернизации старой инфраструктуры и создания новой с целью подготовки условий для развития возобновляемой энергетики и повышения эффективности энергетических систем стран-членов.

Завершающим этапом формирования единого энергетического рынка стало принятие в 2009 г. Третьего энергетического пакета, включающего Директиву об электроэнергии [16], Директиву о газе [17], постановление о доступе к электроэнергетической сети [43], постановление о доступе к газораспределительной сети [44], Постановление об учреждении Агентства по сотрудничеству органов регулирования энергетики [42].

В директивы 2009 г. были включены новые существенные положения, которые отсутствовали в принятых ранее нормативных пра-

\footnotetext{
* Поскольку создание единого газового рынка напрямую зависит от диверсификации поставок данного топлива в ЕС и, соответственно, относится к внешней составляющей энергетической политики, в данной работе он анализируется только в рамках положений Третьего энергетического пакета.
} 
вовых актах по вопросам единого энергетического рынка. Среди них, в частности, можно указать следующие:

- развитие сотрудничества в целях обеспечения двусторонней и региональной солидарности для предотвращения возможных перебоев в поставках природного газа (ст. 6 Директивы о газе) [17];

- развитие сотрудничества между регионами в целях создания региональных рынков электроэнергии и газа (ст. 6 Директивы об электроэнергии и ст. 7 Директивы о газе) [16; 17];

- распространение на третьи стороны требований о разделении видов деятельности компаний во избежание монополизации систем поставки, передачи и распределения, а также возможность назначения независимых операторов систем передачи (магистральных трубопроводов и линий электропередачи (ЛЭП);

- обязанность оператора системы передачи разрабатывать и реализовывать каждые 10 лет план развития и модернизации системы (после утверждения регулирующим органом) (ст. 22) [16; 17].

В совокупности названные положения предполагали последовательное укрепление безопасности поставок электроэнергии и природного газа, а также поддержание необходимой инфраструктуры в надлежащем состоянии для стабильного функционирования единого энергетического рынка.

Кроме того, в соответствии с Третьим энергетическим пакетом была создана Ассоциация европейских операторов сетей электропередачи (ENTSO-E) [43] и Ассоциация европейских операторов газовых сетей (ENTSO-G) [44], основная задача которых - разрабатывать кодексы соответствующих сетей. В свою очередь Агентство по сотрудничеству органов регулирования энергетики координирует деятельность указанных организаций, обеспечивает взаимодействие между национальными органами регулирования, проводит мониторинг цен и тарифов на электроэнергию и природный газ, а также следит за обеспечением прав потребителей [42].

Каждому государству - члену Европейского союза вменялось в обязанность провести имплементацию двух директив в национальное законодательство до 3 марта 2011 г., за исключением ст. 11, для которой срок устанавливался до 3 марта 2013 г. [16; 17], и соблюдать требования постановлений. Как и в случае с предыдущими нормативными правовыми документами единого энергетического рынка, процесс имплементации происходил неравномерно. Например, в июне 2010 г. 
Европейская комиссия направила 20 членам Евросоюза запросы на имплементацию и исполнение требований Третьего энергетического пакета [5]. В 2012 г. число стран, которые не в полном объеме провели необходимые изменения в своем законодательстве, сократилось до 3 [11; 34], а в феврале 2014 г. Европейская комиссия подала в Европейский суд за неисполнение Третьего энергетического пакета лишь на Ирландию [35].

Хотя необходимость развивать региональные рынки электроэнергии и газа была закреплена лишь в Третьем энергетическом пакете, сотрудничество в этом направлении между государствами-членами началось еще в 2006 г. Оно ознаменовалось подписанием 8 декабря 2006 г. польской компанией «Polskie Sieci Elektroenergetyczne» и литовской «Lietuvos Energija» соглашения о строительстве соединительной линии электропередачи между городами Алитус (Литва) и Элк (Польша), которое в тот же день поддержали премьер-министры обеих стран. Стоимость проекта оценивалась в 304 млн евро [21].

А 12 февраля 2008 г. операторы систем электропередачи Литвы и Польши заключили соглашение о создании соединительной линии между электроэнергетическими сетями двух стран, а также о подключении прибалтийской сети к континентальной (Польша, Германия) [22].

В апреле 2009 г. правительства Латвии, Литвы, Эстонии и Швеции заключили соглашение о прокладке по дну Балтийского моря кабеля, который, объединив электроэнергетические сети Прибалтики и стран Северной Европы, должен был способствовать формированию единого рынка электроэнергии между двумя регионами [23].

17 июня 2009 г. в Брюсселе при участии председателя Еврокомиссии Ж. М. Баррозу был подписан меморандум о взаимопонимании, который положил начало реализации Плана объединения Балтийского рынка электроэнергии (BEMIP), т. е. создания единого рынка электроэнергии стран Северной Европы, Прибалтики, Польши и Германии [37].

Одновременно с развитием активного сотрудничества по созданию единого рынка электроэнергии в регионе Балтийского моря проводилась работа по объединению электроэнергетических сетей в других частях ЕС. В июне 2007 г. состоялось подписание меморандума о взаимопонимании, в соответствии с которым в единый региональный рынок электроэнергии объединялись рынки Франции, Германии, 
Бельгии, Нидерландов и Люксембурга [8]. В 2008 г. правительства Испании и Франции заключили соглашение о строительстве соединительной линии электропередачи [7], а реализация этого проекта стоимостью 700 млн евро началась в 2009 г.

4 февраля 2014 г. 14 государств - членов Евросоюза и Норвегия запустили пилотный проект по торговле электроэнергией - так называемый объединенный рынок следующего дня [32].

В мае 2014 г. к данному рынку присоединились Испания и Португалия [11]. В ноябре 2014 г. между Чехией, Словакией, Венгрией и Румынией начал функционировать аналогичный рынок [14], который в соответствии с планами правительств данных государств должен стать частью единого рынка на западе Европы.

Что касается финансирования развития энергетической инфраструктуры Европейского союза, то оно осуществлялось в рамках нескольких инструментов.

В 2010 г. Европейская комиссия выделила 2,3 млрд евро на 31 газовый и 12 электроэнергетических проектов. Средства предоставлялись в соответствии с планом восстановления экономики [19]. В октябре 2011 г. Еврокомиссия представила новый Финансовый механизм развития транспортной, энергетической и телекоммуникационной инфраструктуры (Connecting Europe Facility), согласно которому до 2020 г. на реализацию инфраструктурных проектов в ЕС выделялось 50 млрд евро.

Предполагалось, что до 9,1 млрд евро будет инвестировано в трансъевропейскую энергетическую инфраструктуру [13], но в 2013 г. ЕК определила 250 проектов, которые до 2020 г. получат 5,85 млрд евро из бюджета ЕС [6].

В 2014 г. в рамках данного финансового механизма Евросоюз инвестировал в первоочередные проекты 750 млн евро [4]. Следует отметить, что проекты в сфере электроэнергетики в первую очередь связаны с созданием внутреннего единого рынка, в то время как развитие инфраструктуры для доставки и распределения природного газа предполагает диверсификацию поставщиков и путей доставки и соответственно сотрудничество с третьими странами.

В 2006-2014 гг. проекты в сфере энергетики финансировались за счет кредитов Европейского инвестиционного банка (ЕИБ). В 2010 г. кредиты указанного банка на энергетические проекты достигли пика на уровне 32,2 млрд евро [31], что совпало с экономическим подъе- 
мом в ЕС после финансово-экономического кризиса (-4,4 \% в 2009 г. против 2,1 \% в 2010 г.) [41].

Формированию единого рынка электроэнергии Европейского союза также должно способствовать развитие возобновляемой энергетики. В 2009 г. ЕС принял Директиву о возобновляемых источниках энергии, которая установила обязательные целевые показатели для каждого государства-члена до 2020 г.: 20 \% - ВИЭ в валовом потреблении энергии и $10 \%$ - доля ВИЭ на всех видах транспорта. При этом каждая страна обязана разработать и направить в Европейскую комиссию национальный план действий с указанием мер по достижению целевых показателей до 2020 г. в транспортном секторе, электроэнергетике и т. д. (ст. 4). Сами же показатели для отдельных государств-членов определяются директивой (прил. II). При этом отчеты о ходе выполнения ее требований должны предоставляться в Еврокомиссию каждые 2 года [15].

В соответствии с директивой страны ЕС наделены правом реализации как совместных проектов, так и проектов с привлечением третьей стороны. Директива требует оптимизации и упрощения всех административных процедур, которые затрагивают разработку, утверждение и осуществление проектов в сфере возобновляемой энергетики (ст. 13) [15].

В 2006 г. на ВИЭ приходилось 14,7 \% производства первичной энергии в ЕС. Возобновляемая энергия находилась на четвертом месте после природного газа $(20,6 \%)$, угля $(21,9 \%)$ и атомной энергии (29,8 \%) [28]. К 2012 г. с ситуация изменилась: ВИЭ оказались на втором месте с 22,3 \% после атомной энергии (28,7 \%) [30; 39]. По данным Bloomberg New Energy Finance, инвестиции в возобновляемую энергетику в ЕС резко выросли с 23,5 млрд долл. в 2004 г. до рекордных 121,6 млрд долл. в 2011 г., однако в 2012 г. упали до 86,5 млрд долл. [36]. Но даже это падение более чем в три с половиной раза превышает уровень 2004 г.

В европейских странах наиболее широко представлены такие альтернативные виды источников, как энергия ветра, солнца, воды, геотермальная энергия, а также биомасса и отходы. Самыми перспективными считаются гидроэнергетика (преимущественно малая), ветроэнергетика и использование энергии солнца. Тем не менее в сово-

\footnotetext{
* 2012 г. - последний год, для которого доступны официальные данные Eurostat по всем рассматриваемым показателям.
} 
купной выработке первичной энергии из ВИЭ наибольшая доля приходилась на биомассу и отходы (в 2012 г. составляла 65,5 \%), за которыми следовала гидроэнергетика $(16,2 \%)$ и ветроэнергетика $(10 \%)$ [40].

После принятия в 2009 г. Директивы о возобновляемых источниках энергии показательным стало трехкратное увеличение доли солнечной энергетики в совокупной выработке электроэнергии с помощью ВИЭ: с 1,7\% в 2009 г. до 5,1\% в 2012 г. Кроме того, доля ветроэнергетики увеличилась с 7,7 до $10 \%$. Однако по остальным видам ВИЭ наблюдалось незначительное снижение в пределах 2-3\% [29].

Гидроэлектростанции представляют один из традиционных способов получения электроэнергии. В 2012 г. в Европейском союзе ГЭС вырабатывали около $335 \mathrm{TBT}^{\mathrm{x}}$ [26]. Эксперты отмечают, что европейские страны задействовали практически все реки, пригодные для строительства ГЭС. Поэтому в настоящее время предпочтение отдается малой гидроэнергетике, «работающей от силы течения малых рек, каналов и т. п. и дающей до 10 \% общего объема гидроэлектроэнергии в ЕС» [2, с. 34]. В связи с этим следует отметить, что объемы выработки электроэнергии на ГЭС в разные годы колебались незначительно, достигнув максимума в 2010 г. на уровне $375 \mathrm{TBT}^{\mathrm{x}}$ [26].

Ветроэнергетика представляет собой одну из наиболее динамично развивающихся отраслей альтернативной энергетики не только в Европе, но и во всем мире. В 2012 г. общая выработка электроэнергии на ветроэнергетических установках достигла 205,8 ТВт $^{\mathrm{x}}$ [26]. Лидерами в названной сфере среди членов ЕС являются Германия, Испания и Великобритания, что объясняется благоприятными природными условиями в этих странах (сильные ветры и наличие выхода к морю позволяют строить ветроэнергетические установки в прибрежных зонах, где ветры дуют с большей силой). В Германии доля электроэнергии, выработанной на ветроэнергетических установках, составила 50,7 $\mathrm{TBT}^{\mathrm{x}}$, или $1 / 4$ от общей выработки электроэнергии в Евросоюзе. Общие инвестиции ФРГ в возобновляемую энергетику в 2012 г. достигли 22,8 млрд долл., из которых 3,1 млрд долл. $(13,6 \%)$ пришлись на ветроэнергетику [33; 36].

Если учитывать мировые тенденции, то «в будущем ветроэнергетика может стать для Европейского союза решающим фактором в обеспечении энергетической безопасности, поскольку природные ус- 
ловия Западной Европы более всего пригодны для активного развития именно этой отрасли альтернативной энергетики» [2, с. 20]. Выступая в сентябре 2009 г. на конференции в Стокгольме, еврокомиссар по энергетике А. Пибалгс подчеркнул особую роль морских ветроэнергетических установок в преодолении проблем энергообеспечения. Он отметил, что к 2030 г. на таких установках может вырабатываться почти $3000 \mathrm{TBT}^{\mathrm{x}}$ энергии, что практически полностью удовлетворит потребности ЕС в электроэнергии [38].

Тем не менее в отчете о ходе выполнения Директивы о возобновляемой энергетике за 2011-2012 гг. Европейская комиссия указала на то, что страны не выполняют свои целевые показатели в данном секторе, вследствие чего к 2020 г. на ветроэнергетических установках в совокупности будет выработано лишь 463 ТВтех $^{x}$ в сравнении с целевым показателем $854 \mathrm{TBT}^{\mathrm{x}} \mathbf{4}$ [9].

Гелиоэнергетика по объемам выработки электроэнергии (в 2012 г. - 105,9 ТВт $^{\mathrm{x}}$ [26]) более чем в три раза уступает гидроэнергетике и более чем в два раза - ветроэнергетике. Лидерами в ЕС в данном секторе являются Германия, Испания и Италия. В странах Прибалтики солнечная энергетика не представлена (Эстония, Латвия) или представлена крайне малыми объемами (Литва) в общем производстве электроэнергии. Значительные региональные различия в этой сфере обусловлены природно-климатическими особенностями: гелиоэнергетика рентабельна лишь там, где имеется достаточно большое количество солнечных дней в году. В результате возникает необходимость перераспределять между странами и регионами Евросоюза объемы и потоки электроэнергии в целях обеспечения бесперебойного функционирования энергосетей.

Еврокомиссия отметила общие успехи государств-членов в развитии солнечной энергетики: активно растут объемы выработки электроэнергии, целевой показатель по выработке в секторе превышен примерно на $31 \%$.

Однако в отчете о ходе выполнения Директивы о возобновляемых источниках указывается на то, что в целом государства оказались не готовы к такому интенсивному увеличению производства электроэнергии за счет энергии солнца, в результате чего ее избыток быстро израсходуется, в условиях экономического кризиса страны не сумеют адаптировать свои схемы поддержки гелиоэнергетики, и, как следствие, положительная динамика будет утеряна [10]. 
Что касается производства биогаза, используемого для выработки электроэнергии, то его объемы стабильно увеличивались с 4 394,5 тыс. т нефтяного эквивалента (далее - т н. э.) в 2006 г. до 12071,3 тыс. т н. э. в 2012 г. [40].

Несмотря на прогресс в реализации Директивы о возобновляемых источниках энергии, Европейская комиссия определила ряд проблем данной отрасли:

- повышение рисков для проектов в сфере ВИЭ вследствие сложных административных процедур и переносов сроков;

- медленные темпы развития и модернизации необходимой инфраструктуры;

- пересмотр схем поддержки возобновляемой энергетики в странах-членах, обусловленный ухудшением экономического климата [10].

Следует отметить, что возобновляемая энергетика - это одно из ключевых средств диверсификации источников энергии. С одной стороны, она позволяет сократить потребление нефти, природного газа и угля в Европейском союзе, что в свою очередь способствует снижению объемов импорта данных энергоносителей. С другой стороны, развитие ВИЭ подразумевает создание «зеленой», экологически чистой экономики, которая согласуется с целями ЕС в области борьбы с изменением климата. В то же время важнейшим направлением внутренней энергетической политики Брюсселя является энергосбережение и внедрение энергоэффективных технологий, что в конечном счете должно привести к повышению конкурентоспособности экономики объединения.

В Европейском союзе потребление энергии от первичных источников снижалось с 2006 г., достигнув в 2009 г. 1593,1 млн т н. э., однако в 2010 г. резко выросло до 1652,4 млн т н. э., но к 2012 г. вновь сократилось до 1583,9 млн т н. э. [27].

При этом целевой показатель на 2020 г. составляет 1483 млн т н. э. Конечное энергопотребление продемонстрировало аналогичную динамику: снижение с 1187,2 млн т н. э. в 2006 г. до 1102,2 млн т н. э. в 2012 г. [27]. В рассматриваемый период также снизилась энергоемкость экономики Евросоюза: с 159,3 кг нефтяного эквивалента (кг н. э.)/1000 евро в 2006 г. до 143,4 кг н. э/1000 евро в 2012 г. [24]. Более того, страны - члены ЕС добились существенных успехов в энергосбережении: к 2012 г. в потреблении энергии от пер- 
вичных источников оно достигло 10,49 \%, а в конечном энергопотреблении - 12,11\% [30].

В октябре 2012 г. ЕС принял Директиву об энергоэффективности, которая определила общий комплекс мер, призванных обеспечить выполнение странами-членами целевого показателя по энергоэффективности на уровне 20 \% к 2020 г. [18]. При этом установленные в документе показатели на период до 2020 г. являются минимальными и каждое государство - участник ЕС может предпринимать дополнительные шаги, способствующие достижению более высоких результатов. Меры и требования, изложенные в Директиве, обязательны к исполнению всеми странами-членами. Каждое правительство должно разработать собственный план действий в сфере энергоэффективности и энергосбережения.

Таким образом, в 2006-2014 гг. в Европейском союзе завершилось законодательное оформление единого энергетического рынка. Процесс гармонизации нормативно-правовой базы и имплементации положений Третьего энергетического пакета в национальное законодательство стран-членов проходил неравномерно, однако к концу 2014 г. большинство государств выполнили необходимые требования. Учитывая различные уровень развития и степень износа энергетических сетей, в рассматриваемый период наиболее эффективным путем формирования единого рынка стало региональное сотрудничество стран - членов ЕС по объединению электроэнергетических сетей и рынков.

В результате образовались три региональных рынка электроэнергии: рынок Западной Европы, рынок Центральной и Восточной Европы и Прибалтийский рынок. В случае успешной модернизации энергосетей данные региональные рынки составят единый рынок электроэнергии ЕС.

Одновременно с формированием энергетического рынка ЕС продолжалось развитие сектора возобновляемой энергетики, при этом наилучшие результаты с точки зрения объемов выработки продемонстрировала солнечная энергетика. Однако в рассматриваемых временных рамках также наблюдалось сокращение инвестиций в ВИЭ и сформировалась тенденция снижения темпов наращивания выработки электроэнергии из альтернативных источников из-за неблагоприятных экономических условий. Если производители электроэнергии предпочтут в условиях падения цен на нефть и газ перей301 
ти на указанные энергоносители в качестве преобладающих видов топлива, то это усугубит наметившиеся негативные явления в секторе возобновляемой энергетики и не позволит Брюсселю достичь к 2020 г. 20-процентной доли ВИЭ в валовом потреблении электроэнергии.

В то же время Европейский союз добился существенных успехов в сфере энергоэффективности и энергосбережения, обеспечив к концу 2012 г. показатель энергосбережения в конечном потреблении на уровне свыше $12 \%$. При сохранении данного импульса в будущем государства-члены к 2020 г. не только достигнут, но и смогут превысить целевой 20-процентный показатель. В результате ЕС существенно сократит энергоемкость ВВП и сможет сконцентрировать усилия на развитии возобновляемой энергетики.

Перспективы внутренней энергетической политики Европейского союза будут зависеть от готовности стран-членов выполнять требования Брюсселя.

Обязательный характер Третьего энергетического пакета позволил достаточно быстро гармонизировать законодательства участников ЕС в сфере энергетических рынков. В то же время развитие возобновляемой энергетики зависит не только от политической воли руководства отдельных государств, но и от финансовоэкономической ситуации, определяемой в том числе и состоянием мировой экономики. Европейской комиссии для активизации развития «чистой» энергетики необходимо предъявлять более жесткие требования к государствам-членам, за неисполнение которых будут налагаться штрафные санкции. Однако страны могут рассматривать подобные меры как избыточные и не подлежащие исполнению, если они будут противоречить их национальным интересам.

В целом энергетическая политика внутри ЕС способствует дальнейшему сближению стран и регионов и углублению интеграции, однако слишком настойчивое ее проведение Брюсселем может обернуться противодействием участников Евросоюза. Поэтому дальнейшая судьба данного направления уже в рамках Энергетического союза будет зависеть от способности найти баланс между национальными и общеевропейскими интересами. 


\section{Библиографические ссылки}

1. Гудков И. В. Третий энергетический пакет Европейского союза // Нефть, газ и право. 2010. - № 3. - С. 58-66.

2. Каныгин П. С. Экономика возобновляемых источников энергии (на примере ЕС) // Мировая экономика и междунар. отношения. -2009. - № 6. - С. 31-42.

3. Падалко Л. П., Волошенюк Д. А. Развитие рынка природного газа в Европе и путей его доставки с использованием трубопроводного транспорта // Экон. бюл. НИЭИ М-ва экономики Респ. Беларусь. - 2010. - № 1. - С. 4-13.

4. Commission releases $€ 750$ million for infrastructure projects // European Commission Press Release Database [Electronic resource]. - URL : http://europa.eu/rapid/press-release_IP-14-547_en. htm (date of access : 21.07.2015).

5. Commission Requests 20 Member States to implement and apply Single Market rules without delay // European Commission Press Release Database [Electronic resource]. - URL : http://europa. eu/rapid/press-release_IP-10-836_en.htm?locale=en (date of access : 14.07.2015).

6. Commission unveils list of 250 infrastructure projects that may qualify for $€ 5,85$ billion of funding // European Commission Press Release Database [Electronic resource]. - URL : http://europa. eu/rapid/press-release_IP-13-932_en.htm (date of access : 21.07.2015).

7. Commission welcomes the agreement on the electricity link between France and Spain // European Commission Press Release Database [Electronic resource]. - URL : http://europa. eu/rapid/press-release_IP-08-1054_en.htm (date of access : 09.09.2015).

8. Commissioner Piebalgs welcomes the creation of a 5-country electricity coupling as a positive step towards a single European energy market // European Commission Press Release Database [Electronic resource]. - URL : http://europa.eu/rapid/press-release_IP-07-770_en.pdf (date of access : 20.07.2015).

9. Communication from the Commission to the European Parliament and the Council. Renewable Energy: Progressing towards the 2020 target: COM(2011) 31 final, Brussels, 31.1.2011 // European Commission Energy Portal [Electronic resource]. - URL : http://eur-lex.europa.eu/legalcontent/EN/TXT/PDF/?uri=CELEX:52011DC0031\&from=EN (date of access : 29.07.2015).

10. Communication from the Commission to the European Parliament, the Council, the European Economic and Social Committee and the Committee of the Regions. Renewable energy progress report: $\operatorname{COM(2013)~} 175$ final, Brussels, 27.3.2013 // European Commission Energy Portal [Electronic resource]. - URL : http://eur-lex.europa.eu/legal-content/EN/TXT/PDF/?uri=CELEX: 52013DC0175\&from=EN.(date of access : 29.07.2015).

11. Communication from the Commission to the European Parliament, the Council, the European Economic and Social Committee and the Committee of the Regions. Progress towards completing the Internal Energy Market: COM(2014) 634 final, Brussels 13.10.2014 // European Commission Energy Portal [Electronic resource]. - URL : https://ec.europa.eu/energy/sites/ener/files/documents/ 2014_iem_communication_0.pdf (date of access: 21.07.2015).

12. Conclusions of the European Council: Doc. EUCO 2/11, CO EUR 2, CONCL 1, Brussels, 4 February $2011 / /$ Council of the European Union [Electronic resource]. - URL : http://data. consilium.europa.eu/doc/document/ST-2-2011-INIT/en/pdf (date of access : 11.07.2015).

13. Connecting Europe Facility: Commission adopts plan for $€ 50$ billion boost to European networks // European Commission Press Release Database [Electronic resource]. - URL : http://europa.eu/rapid/press-release_IP-11-1200_en.htm (date of access : 21.07.2015).

14. Czech, Slovak, Hungarian Power Market Coupling Extends to Romania // ENTSO-E Official Website [Electronic resource]. - URL : https://www.entsoe.eu/news-events/announcements/ announcements-archive/Pages/News/Czech,-Slovak,-Hungarian-Power-Market-Coupling-Extendsto-Romania.aspx (date of access : 21.07.2015). 
15. Directive 2009/28/EC of the European Parliament and of the Council of 23 April 2009 on the promotion of the use of energy from renewable sources and amending and subsequently repealing Directives 2001/77/EC and 2003/30/EC // EUR-Lex. Access to European Union Law [Electronic resource]. - URL : http://eur-lex.europa.eu/legal-content/EN/TXT/PDF/?uri=CELEX:32009L0028 $\&$ from $=\mathrm{EN}$ (date of access : 15.07.2015).

16. Directive 2009/72/EC of the European Parliament and of the Council of 13 July 2009 concerning common rules for the internal market in electricity and repealing Directive 2003/54/EC // EURLex. Access to European Union Law [Electronic resource]. - URL : http://eur-lex.europa. eu/LexUriServ/LexUriServ.do?uri=OJ:L:2009:211:0055:0093:EN:PDF (date of access : 11.07.2015).

17. Directive 2009/73/EC of the European Parliament and of the Council of 13 July 2009 concerning common rules for the internal market in natural gas and repealing Directive 2003/55/EC // EUR-Lex. Access to European Union Law [Electronic resource]. - URL : http://eur-lex.europa.eu/ LexUriServ/LexUriServ.do?uri=OJ:L:2009:211:0094:0136:en:PDF (date of access : 11.07.2015).

18. Directive 2012/27/EU of the European Parliament and of the Council of 25 October 2012 on energy efficiency, amending Directives 2009/125/EC and 2010/30/EU and repealing Directives 2004/8/EC and 2006/32/EC // EUR-Lex. Access to European Union Law [Electronic resource]. URL : http://eur-lex.europa.eu/legal-content/EN/TXT/?uri=celex:32012L0027 (date of access : 29.07.2015).

19. Economic Recovery: Second batch of a 4-billion-euro package goes 43 pipeline and electricity projects // European Commission Press Release Database [Electronic resource]. - URL : http://europa.eu/rapid/press-release_IP-10-231_en.htm?locale=fr (date of access : 21.07.2015).

20. Eikeland P.O. The Third Internal Energy Market Package: New Power Relations among Member States, EU Institutions and Non-state Actors? // J. of Common Market Studies. - 2011. Vol. 49. - P. 243-263.

21. Energy Commissioner Piebalgs welcomes the agreement for the construction of a LithuanianPolish interconnector // European Commission Press Release Database [Electronic resource]. URL : http://europa.eu/rapid/press-release_IP-06-1814_en.htm (date of access : 17.07.2015).

22. Energy Commissioner Andris Piebalgs welcomes agreement on the implementation of the interconnection project between Lithuania and Poland // European Commission Press Release Database [Electronic resource]. - URL : http://europa.eu/rapid/press-release_IP-08-229_en.htm (date of access : 17.07.2015).

23. Energy Commissioner Andris Piebalgs welcomes the agreement of the three Baltic States on the route of the electricity interconnection project between them and Sweden [Electronic resource] // European Commission Press Release Database. - URL : http://europa.eu/rapid/press-release_IP-09646_en.htm (date of access : 17.07.2015).

24. Energy intensity of the economy: Eurostat Database // Eurostat Official Website [Electronic resource]. - URL : http://ec.europa.eu/eurostat/tgm/table.do?tab=table\&init=1\&plugin=1\&pcode= tsdec360\&language $=$ en (date of access : 29.07.2015).

25. Energy and Security : Strategies for a World in Transition. - 2nd ed. / ed. by J. H. Kalicki and D. L. Goldwyn. - Washington, D.C., Baltimore : Woodrow Wilson Center Press / Johns Hopkins University Press.

26. Energy, transport and environmental indicators : 2014 edition // Eurostat Official Website [Electronic resource]. - URL : http://ec.europa.eu/eurostat/documents/3930297/6613266/KS-DK-14001-EN-N.pdf/4ec0677e-8fec-4dac-a058-5f2ebd0085e4 (date of access : 29.07.2015).

27. Energy saving - annual data: Eurostat Database // Eurostat Official Website [Electronic resource]. - URL : http://appsso.eurostat.ec.europa.eu/nui/show.do?dataset=nrg_ind_334a\&lang=en (date of access : 29.07.2015). 
28. Europe in Figures: Eurostat Yearbook 2009 // Eurostat Official Website [Electronic resource]. URL : http://ec.europa.eu/eurostat/documents/3217494/5708435/KS-CD-09-001-EN.PDF/f16d 286f-48bf-4e13-a4bb-c10b2b7832e0?version=1.0 (date of access : 29.07.2015).

29. Europe in Figures: Eurostat Yearbook 2012 // Eurostat Official Website [Electronic resource]. URL : http://ec.europa.eu/eurostat/documents/3217494/5760825/KS-CD-12-001-EN.PDF (date of access : 29.07.2015).

30. Europe in Figures : Eurostat Yearbook 2014 // Eurostat Official Website [Electronic resource]. URL : http://ec.europa.eu/eurostat/statistics-explained/index.php/Europe_in_figures_-_Eurostat_ yearbook (date of access : 29.07.2015).

31. European Investment Bank Annual Report 2010. Statistical Report // European Investment Bank Official Website [Electronic resource]. - URL : http://www.eib.org/attachments/general/reports/ st2010en.pdf (date of access : 12.07.2015).

32. Giannoulis K. North-Western European Price coupling (NWE) starts today // New Europe Portal [Electronic resource]. - URL : http://www.neurope.eu/article/launch-eu-project-joint-electricitytrading/ (date of access : 21.07.2015).

33. Global Trends in Renewable Energy Investment 2013 // United Nations Environmental Program Official Website [Electronic resource]. - URL : http://www.unep.org/pdf/GTR-UNEP-FSBNEF2.pdf (date of access : 29.07.2015).

34. Internal energy market: national legislation in 3 Member States is still not fully in line with EU rules // European Commission Press Release Database [Electronic resource]. - URL : http://europa.eu/rapid/press-release_IP-12-639_en.htm?locale=en (date of access : 14.07.2015).

35. Internal energy market: Commission refers Ireland to Court for failing to transpose EU rules // European Commission Press Release Database [Electronic resource]. - URL : http://europa.eu/rapid/press-release_IP-14-155_en.htm (date of access : 14.07.2015).

36. Liebreich M. Global Trends in Clean Energy Investment 2013 // Bloomberg New Energy Finance [Electronic resource]. - URL : http://about.bnef.com/presentations/bnef-summit-2013keynote-presentation-michael-liebreich-bnef-chief-executive/ (date of access : 29.07.2015).

37. Memorandum of Understanding on the Baltic Energy Market Interconnection Plan // European Commission Energy Portal [Electronic resource]. - URL : https://ec.europa.eu/energy/ sites/ener/files/documents/2009_bemip_mou_signed.pdf (date of access : 20.07.2015).

38. Piebalgs A. Offshore wind energy - a climate-friendly power system // European Commission Press Release Database [Electronic resource]. - URL : http://europa.eu/rapid/press-release_ SPEECH-09-387_en.htm?locale=en (date of access : 29.07.2015).

39. Primary production of renewable energy, 2002 and 2012: Eurostat Database // Eurostat Official Website [Electronic resource]. - URL : http://ec.europa.eu/eurostat/statistics-explained/ index.php/File:Primary_production_of_renewable_energy,_2002_and_2012_YB14.png\#file (date of access : 29.07.2015).

40. Primary production of renewable energy by type: Eurostat Database // Eurostat Official Website [Electronic resource]. - URL : http://ec.europa.eu/eurostat/tgm/refreshTableAction.do?tab= table\&plugin $=1 \&$ pcode $=$ ten00081\&language $=$ en $($ date of access $: 29.07 .2015)$.

41. Real GDP growth rate - volume: Eurostat Database // Eurostat Official Website [Electronic resource]. - URL : http://ec.europa.eu/eurostat/tgm/table.do?tab=table\&init=1\&language=en $\&$ pcode= tec00115\&plugin $=1$ (date of access : 12.07.2015).

42. Regulation (EC) No 713/2009 of the European Parliament and of the Council of 13 July 2009 establishing an Agency for the Cooperation of Energy Regulators // EUR-Lex. Access to European Union Law [Electronic resource]. - URL : http://eur-lex.europa.eu/LexUriServ/LexUriServ.do?uri= OJ:L:2009:211:0001:0014:EN:PDF (date of access : 11.07.2015).

43. Regulation (EC) No 714/2009 of the European Parliament and of the Council of 13 July 2009 on conditions for access to the network for cross-border exchanges in electricity and repealing Regulation (EC) No 1228/2003 // EUR-Lex. Access to European Union Law [Electronic resource]. - 
URL : http://eur-lex.europa.eu/legal-content/EN/TXT/PDF/?uri=CELEX:32009R0714\&from=EN (date of access : 11.07.2015).

44. Regulation (EC) No 715/2009 of the European Parliament and of the Council of 13 July 2009 on conditions for access to the natural gas transmission networks and repealing Regulation (EC) No 1775/2005 // EUR-Lex. Access to European Union Law [Electronic resource]. - URL : http://eurlex.europa.eu/legal-content/EN/TXT/PDF/?uri=CELEX:32009R0715\&from=EN (date of access : 11.07.2015).

Внутренняя энергетическая политика Европейского союза в 20062014 г2. (Александр Чиж)

В 2006 г. Европейский союз взял курс на формирование и активную реализацию энергетической политики, которая направлена на обеспечение стабильности энергоснабжения стран-членов и снижение зависимости от импорта энергоносителей. Внутренняя составляющая данной политики включает создание единого энергетического рынка внутри ЕС, развитие возобновляемой энергетики и осуществление программ энергоэффективности. В настоящей статье проанализированы основные направления внутренней энергетической политики Евросоюза в период с 2006 по 2014 г., а также рассмотрены ее проблемы и перспективы.

\section{Ключевые слова}

Энергетическая безопасность; внутренняя энергетическая политика; единый энергетический рынок; возобновляемые источники энергии; энергоэффективность.

\section{Internal Energy Policy of the European Union in 2006-2014 (Alexander} Chizh)

In 2006, the European Union initiated formation and active implementation of energy policy, aimed at securing stable energy supply of the Member States and reducing dependence of the Member States from energy imports. The internal energy policy includes establishing of a single energy market within the EU, renewable energy development and implementation of energy efficiency programmes. This article discusses the main areas of the EU internal energy policy in 2006-2014 as well as its challenges and prospects. 


\section{Key words}

Energy security; internal energy policy; single energy market; renewable energy sources; energy efficiency.

Статья поступила в сентябре 2015 г.

\section{Рецензенты:}

Свилас С. Ф. - кандидат исторических наук, доцент факультета международных отношений Белорусского государственного университета:

Есин Р. О. - доктор политических наук, профессор кафедры международных отношений Академии управления при Президенте Республики Беларусь. 


\section{ВКЛАД ВЫХОДЦЕВ ИЗ БЕЛАРУСИ В СТАНОВЛЕНИЕ ГОСУДАРСТВА ИЗРАИЛЬ}

\section{K. В. Шux}

магистрант факультета международных отномений Белорусского государственного университета

УДК 94(569.4)(=161.3)

Попытка изучить данную проблему обусловлена тем, что интерес в Республике Беларусь к созданию современного Израиля вполне оправдан. Ведь на нашей земле со Средних веков евреи жили рядом с нашими предками и сохраняли свою веру и самобытность.

Цель данной работы состоит в том, чтобы показать участие белорусских евреев в сложнейшем процессе возрождения государства. При этом автор осознает определенную условность термина «белорусские евреи», поскольку наиболее простым вариантом было бы говорить о «евреях - выходцах из белорусских земель». Вместе с тем опыт совместного проживания евреев и белорусов, веротерпимость белорусского окружения (в меньшей степени это характерно для периода, когда Беларусь находилась в составе Российской империи и Советского Союза) не могли быть лишены определенного взаимного влияния, что делает оправданным разговор именно о «белорусских евреях».

Объектом работы являются белорусские евреи, в частности те, кто выехал из Беларуси в Палестину в период с конца XIX до конца XX в.

Для изучения данной проблемы были использованы источники из Национальной библиотеки Республики Беларусь и Национального архива Республики Беларусь. В их числе работы Е. Розенблата, Э. Иоффе, Л. Смиловицкого [1].

Научные публикации, исследования, мемуары приподнимают завесу над тем, как закладывались основы сегодняшнего Израиля, велась борьба за его международное признание и выживание, как в целом происходило строительство государства и какую роль в этом сыграли наши соотечественники. Необходимо отметить, что данная тема слабо изучена как в отечественной, так и в западной научной литературе. Эту проблему исследовал профессор Э. Иоффе - ученый, 
педагог, знаток истории евреев Беларуси. Одним из немногих специалистов, который занимается данной темой в Израиле, является 3. Ханин - профессор отделения общей политологии и региональной политики Университета Ариэль в Самарии, преподаватель политических наук Университета Бар-Илан, главный ученый министерства абсорбции Израиля.

Для написания данной работы были предприняты все возможности для поиска информации не только в пределах Республики Беларусь, но и за ее пределами. В частности, была проделана значительная работа по поискам родственников, чьи фамилии фигурируют в работе. Автор хотел бы выразить особую благодарность за помощь в поиске информации профессору Еврейского университета в Иерусалиме М. Гриншпан и ее супругу М. Каплан. В западной литературе акцент делается на исследованиях именно выходцев из Советского Союза в целом, а не отдельных государств, что, вероятно, наиболее актуально для понимания данного процесса.

В ходе исследования применялись следующие методы: системный, позволивший проанализировать процесс организации и становления государства; исторический, обусловливающий рассмотрение эволюции становления и развития Государства Израиль, метод сравнительного анализа, ибо он раскрывает деятельность и вклад наших выходцев в развитие Государства Израиль.

Метод исторического анализа помог проследить эволюцию становления и значимость вклада выходцев из Беларуси в этом процессе. Для понимания специфики становления Государства Израиль необходимо обратить внимание как на факты из прошлого, так и на современные этапы его становления.

Кроме общенаучных используются специально-исторические методы: сравнительно-исторический, определяющий сходства и различия между изучаемыми явлениями, а также проблемно-хронологический.

Метод функционального анализа в данной работе определяет роль, которую выходцы из Беларуси как исторический, социальный и культурный институт выполняют относительно потребностей общественной системы.

Научная новизна данной работы заключается в том, что впервые в историографии комплексно исследуется вклад и значимость того, что сделали наши выходцы в Израиле. С позиции нового видения на 
основе первоисточников объективно показана роль выходцев из Беларуси в условиях становления и развития Государства Израиль.

Условия проживания евреев на белорусских землях до их вхождения в состав Российской империи позволяли еврейской нации развиваться с опорой на традиционную духовность и традиции при общей толерантности окружающей социальной среды. Вместе с тем сформировавшиеся в российском обществе и государстве в конце XIX в. антиеврейские настроения привели к созданию предпосылок для роста антисемитизма вплоть до такой его уродливой формы, как погромы [2].

Для того чтобы сохранить свою идентичность, белорусским евреям пришлось преодолеть множество препятствий: введение двойного налога, насильственное переселение из сельской местности в города, запреты на ношение еврейской одежды, дискриминационное законодательство.

Несмотря на притеснения со стороны властей на протяжении семи веков, а также попытки принудительно ассимилировать еврейское население, белорусские евреи сумели не только сохранить свою культуру и традиции, но и возродили свой язык. Бен-Иегуда писал: «Если можно восстановить язык, на котором перестали говорить, и сделать его разговорным, выражающим все, что хочет сказать хотя бы один человек, то, несомненно, такой язык можно сделать разговорным языком и для всего общества» [3].

Одна из важных характеристик белорусского еврейства - состояние культуры и образования. В течение столетий, когда белорусская нация и еврейская проживали вместе, они многое заимствовали друг у друга. В языках, обычаях, легендах, в строительстве и обыденной жизни эти формы так перемешались, что приняли новую самобытную окраску.

Вместе с тем ухудшение социально-экономического положения в Российской империи, формирование идеологии сионизма на основе сохранения еврейской духовности, самобытности и стремления к обретению своего государства привело к началу организованного переселения евреев, в том числе с белорусских земель, в земли Палестины с целью подготовки почвы для создания современного государства.

Цель, поставленная евреями, при значительном вкладе уроженцев белорусских земель была достигнута. Вместе с Д. Бен-Гурионом Декларацию независимости Израиля подписали члены Временного 
государственного совета страны. Среди них было 7 выходцев из белорусских земель: могилевчанин Э. М. Берлин, уроженец Волковыска 3. Варгафтиг и уроженец местечка Нарочевичи на Минщине А. Цизлинг, член Народного правления Израиля пинчанин М. Колодный, член правления Еврейского агентства минчанин Э. Каплан, председатель В. Леумми, уроженец местечка Копысь Д. Ремез и начальник отдела репатриации Еврейского агентства М. Шапира из Гродно [4].

Активные и решительные действия евреев, идеологически обосновавших свою задачу, организовавших массовое переселение своих соотечественников в Палестину, вооруженную борьбу, помноженную на дипломатические успехи, сделали реальностью провозглашение Государства Израиль.

Создание современного Израиля стало следствием настойчивой и целенаправленной работы евреев, рассеянных по всему миру.

Следует отметить, что наши выходцы внесли значительный вклад в развитие таких сфер, как:

1. Политика. Белорусские евреи возглавляли основные политические институты; представляли Государство Израиль на высшем уровне в самые сложные для страны времена. Из девяти президентов Государства Израиль трое (Х. Вейцман, 3. Шазар и Ш. Перес) родились в Беларуси, а у Э. Вейцмана, седьмого президента Израиля, родом из Пинска родители.

Среди израильских премьер-министров нашими земляками были три человека (М. Бегин, И. Шамир, Ш. Перес), тогда как у семи других премьер-министров - М. Шарета, И. Алона, Г. Меир, И. Рабина, А. Шарона, И. Шамира и Б. Нетанияху - имеются корни на территории современной Беларуси. Белорусские корни имеют: 3. Варгафтинг - министр по делам религии; Э. Каплан - первый министр финансов, заместитель премьер-министра страны; М. Коль - министр туризма; М. Д. Ремез - первый министр транспорта, министр образования и культуры; М. Шапира - министр внутренних дел, здравоохранения и абсорбции, министр по религиозным делам; дипломаты Д. Гакоген - депутат, посол в Бирме, член делегации Израиля на сессиях ООН, член Комитета иностранных дел и безопасности; Э. Элат первый посол Государства Израиль в США (1948-1950); И. Ткоа - с момента провозглашения Государства Израиль один из самых авторитетных дипломатов, Постоянный представитель Израиля в $\mathrm{OOH}$, посол в Бразилии, СССР. 
2. Экономика. Свой вклад в создание и развитие экономики Государства Израиль внесли ведущие промышленники - Н. Вилбуш, Р. Адиви и Г. Вильбушевич. Благодаря их знаниям города Ашкелон и Хайфа стали одними из ведущих экономических центров современного Израиля. Г. Вильбушевич создал в Израиле первый сталеплавильный завод.

3. Оборона. И. Харэль - человек, чья фамилия является синонимом успеха. Он прославил Государство Израиль в военной сфеpe, а также основал одну из сильнейших спецслужб в мире - Моссад, возглавлял эту структуру в 1948-1963 гг. Х. Ласков - начальник Генерального штаба Армии обороны Израиля, «солдат номер один» в армии Израиля. В историю Израиля также вошел Э. Голомб - один из основателей Хаганы [5].

4. Наука. Развитие науки Государства Израиль тесно связано с именем Хаима Халеви - специалиста в области статистики, экономики и организации медицины, а также Меера Бен-Сасона - известного израильского ученого-историка. В Израиле помнят и чтят память мирового авторитета по теории функций, теории групп и теории чисел, выдающегося ученого-математика, члена Берлинской академии наук И. Шура.

5. Культура. В возрождении национальной культуры страны приняли активное участие поэты Й. Бат-Мирьям (лауреат Государственной премии Израиля), И. Карни (писал на иврите, автор популярной книги «Песни Иерусалима»), писатели Ю. Марголин, А. Ахимеир, С. Полякевич, первым писателем на идиш в Палестине был уроженец г. Чаусы Могилевской губернии 3. Брахот (Брохес Шмуэль). Значительный вклад внесли знаменитая актриса, лауреат Государственной премии Израиля Х. Ровина, Ш. Роденский и лауреат Государственной премии Израиля А. Мескин.

С момента основания современного Израиля наши земляки занимали высокие государственные посты: среди них первые министры финансов, транспорта, сельского хозяйства, абсорбции и здравоохранения, десятки депутатов кнессета, два начальника Генерального штаба, основатели и лидеры ведущих политических партий, известные дипломаты, редакторы газет и руководители радиостанций.

Мало где в мире можно увидеть столь пристальное внимание по отношению к нашим землякам, как в Израиле. Многие из них стали героями, борцами за свободу и независимость. 
Белорусские евреи заложили прочный фундамент для развития взаимовыгодных экономических и политических отношений между нашими государствами.

Сегодня в Израиле им ставят памятники (Х. Вейцман), появляются бульвары и улицы, названные в их честь, (Э. Бен Йегуда, Ш. Дубнов, Э. Каплан, Х. Ласков, К. Луз, М. Усышкин, 3. Шазар). Именем Д. Ремеза (министра транспорта, образования, культуры) назван район Хайфы - Рамат-Ремез [6].

Белорусский и еврейский народы объединяет общая боль невосполнимых потерь в годы Второй мировой войны.

В борьбе за создание евреями своего государства по окончании Второй мировой войны сложилась общая атмосфера, которая была более благоприятна для них, чем для арабов. И не только потому, что евреи были лучше организованы в военном и политическом плане.

Немаловажным фактором послужило то, что на их стороне было моральное преимущество в связи с гибелью в Европе шести миллионов их собратьев. Трагедия Холокоста настолько потрясла мир, что при голосовании в ООН вопроса о создании на территории Палестины еврейского государства с единых позиций выступили даже страны враждующих блоков.

Один из американских историков еврейского происхождения А. Лилиенталь писал: «Только гитлеровское человекоубийство привело к всеобщему приятию мечты сионистов о еврейском государстве» [7].

Многочисленные инженеры, преподаватели, врачи, ученые и деятели искусств, получившие качественное высшее образование в тогдашней Советской Белоруссии, стали тем бесценным и профессиональным «человеческим капиталом», который служит залогом успешного развития в Израиле экономики, науки и культуры.

Опыт воссоздания еврейского государства спустя несколько тысяч лет при активном участии в этом процессе выходцев из Беларуси интересен не только с научной точки зрения. Его значение имеет также прикладной характер: он мог бы быть востребован для консолидации нашего общества с целью построения сильной и процветающей Беларуси.

Вера Бен-Иегуды, посвятившего свою жизнь превращению языка предков из мертвого в современный разговорный, подкрепленная подвижничеством тысяч евреев, стала залогом осуществления заду- 
манного. Опыт евреев напоминает белорусам о необходимости беречь свой родной язык.

При этом уместно отметить, что призыв к возрождению иврита не был актом ксенофобии и не отрицал важности владения иными языками. Это подтверждается практикой сегодняшнего Израиля, граждане которого, как правило, владеют другими языками, в том числе и русским, на котором в стране издаются газеты, выходят телепередачи и т. д.

Республика Беларусь уже прошла важнейшие этапы своего создания, имеет международное признание, сотрудничает с другими странами. Однако вопросы укрепления и защиты государственного суверенитета всегда будут актуальными. В этом смысле отношение израильтян к укреплению независимости своего государства может служить примером для теперешнего и будущих поколений белорусов.

Участие выходцев из Беларуси в создании и укреплении Государства Израиль, роль, которую играют в теперешней жизни страны выходцы из БССР и Республики Беларусь, представляют собой прочную основу для расширения сотрудничества между нашими государствами и ее народами.

\section{Библиографические ссылки}

1. Смиловицкий Л. Евреи Беларуси : из нашей общей истории, 1905-1953. - Минск : АртиФекс, 1999.

2. Розенблат Е., Еленская И. Динамика численности и расселения белорусских евреев в ХХ в. // Диаспоры. - 2002. - № 4. - С. 27-52.

3. Скир А. Еврейская духовная культура в Беларуси : ист.-лит. очерк. - Минск : Маст. літ., 1995.

4. Евреи : по страницам истории / сост.: С. Асиновский, Э. Иоффе. - Минск : Завигар, 1997.

5. Иоффе Э.Г. Страницы истории евреев Беларуси : крат. науч.-попул. очерк / Евр. ун-т в Минске. - Минск : Арти-Фекс, 1996.

6. Белоруссия // Краткая Еврейская энцикл. : [в 11 т.] / гл. ред. И. Орен (Надель), М. Занд. Иерусалим, 1976. - Т. 1. - С. 323-328.

7. Le Foll C. Les juif de Bielorussie dans l'historiographie occidentale et russe // Bull. du Centre de recherche fr. de Jerusalem. - 2002. - № 11. - P. 9-27. 
Вклад выходцев из Беларуси в становление Государства Израиль (Константин Ших)

Статья посвящена изучению вклада выходцев из Беларуси в становление и развитие Государства Израиль. Автор пытается систематизировать историческую, мемуарную информацию и архивные данные, связанные с вкладом в этот процесс выходцев из белорусских земель, и раскрывает задачи, формы и виды деятельности выходцев из белорусских земель. Статья подводит некоторые итоги изучения данной проблемы за последние годы. Показано, что рассмотрение данной темы было бы неполным без экскурса в историю расселения евреев на белорусских землях, сведений об условиях их существования, о взаимовлиянии на местное население. Автор обращает внимание на отсутствие комплексных и всесторонних исследований данной проблемы как в белорусской, так и в израильской историографии.

\section{Ключевые слова}

Беларусь; Израиль; белорусские евреи; выходцы; вклад; государство.

The contribution of immigrants from Belarus to the establishment of the State of Israel (Kanstantin Shykh)

The article is devoted to the research of a contribution of natives of Belarus to formation and development of the State of Israel. The author tries to systematize the historical, memorial information and historical data connected with a contribution of natives of Belarusian lands to this process. The author talks about tasks, forms and kinds of activity of natives of Belarusian lands. The article sums up some results of studying of this problem within recent years. The main content of research makes the analysis of examples of some famous figures. It is shown that the review of this subject would be incomplete without an excursion into the history of settlement of Jews on the Belarusian lands, records about conditions of their existence and interaction with local population. The author points out the lack of complex and comprehensive investigations of this problem both in Belarusian, and in Israeli historiography. 


\section{Key words}

Belarus; Israel; the Belarusian Jews; immigrants; the contribution; state.

Статья поступила в сентябре 2015 г.

Рецензенты:

Шарапо А. В. - доктор исторических наук, профессор кафедры международных отношений факультета международных отношений Белорусского государственного университета;

Решетников С. В. - доктор политических наук, профессор, заведующий кафедрой политологии Белорусского государственного университета. 


\title{
НАУЧНЫЕ ПУБЛИКАЦИИ
}

\author{
Рещензии
}




\title{
SOME WORDS ABOUT POLITICS IN THE EUROPEAN
}

\author{
«POWDER KEG»
}

\section{Shavialiou}

Review of: Wunsch Gaarman, Margit V. The War in Our Backyard. The Bosnia and Kosovo Wars through the Lens of German Print Media.

Berlin: Neofelis, 2015. 294 p.

УДК 327(4)

Dr. Margit Wunsch Gaarman is a faculty member of FriedrichMeinecke Institute of History at Free University of Berlin. She received her Ph.D. in international history from London School of Economics. For several years she thoroughly studied nationalism, ethnicity, and contemporary politics in Southeastern Europe. She was a co-editor of «Political Leadership, Nations and Charisma» (NY, Routledge, 2012) together with Vivian Ibrahim, an assistant professor of University of Mississippi.

The reviewed book by Margit Wunsch explores how the German press described the wars in Yugoslavia in the 1990s. The author focuses on media language, topics, clishés, cartoons, etc. She makes use of a wide range of mass media information - both far-right (Junge Freiheit) and farleft (Konkret), national broadsheets (Die Welt, Der Spiegel) and a tabloid $(B I L D)$, as well as a Jewish weekly by the Central Council of Jews in Germany (Allgemeine Jüdische Wochenzeitung) (p. 16).

The author carefully formulates an academic problem. She points out that on April 1, 1999 the German tabloid BILD published the headline «They are herding them to the concentration camp» on the front page. Other newspapers and magazines from March 29 to April 6, 1999 published that Serbs set up concentration camps for Kosovo - Albanians. A series of such publications accompanied the statement by the German Defense Minister Rudolf Scharping, dated March 28, 1999 who had declared that the «genocide» was coming on in Kosovo. As the journalist Alexandre Levy from «Reporters sans frontières» once mentioned, the term «genocide» was permanently used at that time by German and British officials to put an equal sign between Miloševič and Hitler. In this way the media manipulated the public opinion giving grounds for the changes in German foreign policy - to start intervention to the Balkans, the first one after World War II. After the description of BILD's mistake, Dr. Wunsch puts several questions regarding the media coverage: was BILD the only exam- 
ple of «poor reporting» and «bad journalism», or were there many examples of them, as well as why did the newspapers create allusions about the events of World War II? (p. 14).

Margit Wunsch explains in what way the media coverage concerns the diplomatic history. The press of that time presented a range of various opinions circulated in the political circles in Berlin on German involvement in European affairs after the reunification in 1990. These political debates on foreign relations had their roots in public discourse on the Holocaust and collective memory of World War II (p. 17-18). Researchers who studied German's collective memory found three period of its development. The first one is the «the Adenauer era» (the late 1940s - early 1960s), during which Germans were aware of their responsibility for the Holocaust, but kept silence upon their Nazi past. During the second stage of the public debates on collective memory (the late 1960s - the 1980s) «the 1968-generation» of Germans worked out the concept of «Niewieder Krieg» («Never again war»). This slogan became the principle for the German foreign policy for next decades. The authors of that time - publicists and historians - belonged to the so-called «Betroffenbeitsdiskurs» («discourse of dismay») - the public opinion accepted «a deep, allencompassing shame» for the past (p. 19). In the early 1990s one can observe changes in Germany's collective memory: people do not want to be as guilty as they had been earlier. As he war in Yugoslavia spread in the early 1990s, Germany was forced to choose either just to observe the events or to act. In 1999 Berlin decided to act and punish the aggressors, that is to say Serbs (as they covered in the mass media). Moreover, Germany's involvement in intervention to Kosovo coincided with the time when public debates on that all-national dismay for the Nazi crimes and the Holocaust came to their end (p. 18-20).

The book consists of four important parts. In the first one - an introductory part - the author focuses on political debates related to German foreign policy in the 1990s and the politics of memory in the country after World War II. M. Wunsch explains the terms «genocide» and «ethnic cleansing», both terms are widely associated by the general European public with Serbian policy during the wars in Yugoslavia in the 1990s. Chapter 1 «Historical Background: Important Milestones of Balkan History» presents the so-called «milestones» of the Serbian history: «the region's medieval history, specifically the 1389 Battle of Kosovo and the advent of three major religions, as well as World War Two" (p. 30). Chapter 2 «The 
Eruption of War in the 1990s» briefly outlines the wars in Yugoslavia in the 1990s.

The second part (chapters 3-5) illustrates reports of the German press at the beginning of the war (1991-1992), Srebrenica massacre and the Dayton Accords. In the third part the author of the reviewed book explores the media coverage of the war in Kosovo (1998-1999) - its beginning (chapter 6), the «Račak massacre» (chapter 7) and the NATO intervention to Yugoslavia (chapter 8).

There is no need to re-tell the book from beginning to end - a person interested in good academic reading can read the book by himself / herself. Let us concentrate on the author's conception.

Margit Wunsch challenged the thesis by Phillip Knightley, the British journalist, who affirmed that NATO-states had a monopoly on the media coverage of the wars in the Balkans (p. 15). The author states that in spite of a widely spread view that the Alliance manipulated information during the war in Kosovo, this suggestion was neither proved, nor rejected (p. 16).

The author of the book delves into the German press without any affection either to Serbs or to the opposite sides, and preserves her own academic renommée. She proves that interpretations of the wars in the Balkans made by the German press were not just one-sided. She found several events which received extensive coverage in the media - the Srebrenica massacre, as well as the Račak incident. Those cases were reported by the German press via direct allusions to World War II and the Holocaust in particular. Dr. Wunsch carefully studies texts, their topics, lexicon, messages, as well as cartoons, provided facts, and numerical data.

The author points out that the press payed attention not to «long-term systematic problems in the Balkans», but to «imminent violence» (p. 268). Only four main topics can be found in an array of media materials. Firstly, it is President S. Miloševič who was regarded as the only person responsible for violence (p. 272-273). For instance, at the outbreak of the war in Kosovo Milošhevič became one of the main culprits. Die Welt wrote on March 3, 1998 that the Serbian leader was not «a guarantee for stability, but rather for violence in the Balkans» (p. 171). Cartoons found him guiltyall the more so (see e. g., p. 173-174).

Secondly, the German press wrote only about the Yugoslavian army and Bosnian Serb army. Those combatants, as the media stated, were also guilty of violence and even «genocide» (p. 273). Dr. Wunsh states that one 
article in Frankfurter Allgemiene Zeitung in April 1992 «portrayed the army as the crux of violence, quoting EC-diplomat Lord Carrington who had stated, "...that the "Peoples Army" [was] the true evil in all this confusion”» (p. 61-62).

Thirdly, it is the topic of World War II, which appeared in German newspapers in the 1990s - the lexicon of that time and references to the collective memory of the Holocaust. Dr. Wunsch finds out that while World War II influenced the German press language, references to the Holocaust decreased, especially by the late 1990s. That meant the public debates on the Halacust and all-German guilt for the Nazi crimes (p. 273274) were over. Also, it is worth noting that blaming violence on Serbs the German press extensively used Nazi terms - «Lebensraum», «Blitzkrieg», etc., mentioning that Serbs wanted Lebensraum (Frankfurter Allgemiene Zeitung, February 18, 1992), and they used Blitzkrieg-tactics (die tageszeitung, January 9, 1992) (p. 76-77).

The fourth theme in the book is evaluation of Germany's role in the Balkan politics. Naturally, this resulted from the changes in the country's policy in Southeastern Europe (p. 274). The German media of the early 1990s stressed Germany's realistic role in the Balkans, while the press of the very late 1990s appealed for immediate actions there.

As the author puts it, Russia disappeared from the German newspaper-sheets by the mid-1990s. The German media then stopped its «antiRussian word-choices» (p. 275). According to the author, it can be explained by «the progression of international relations» and the fact that «Russia had become a relatively trusted partner» (p. 275).

In addition to those data and conclusions, the author shares her own photos from Belgrade which left the traces of the war (p. 277, 278). Margit Wunsch has written a proper academic book on information wars. But there are some moments I disagree with in the author's conception. As far as I am concerned, I dislike an idea of milestones in history, not only regarding Serbian history. This concept (of milestones) simplifies the causes and effects of a historical process. It is true that several «cultural zones» were formed in the Balkans during the Middle Ages, and particularly during the Ottoman period (p. 30,32). But an ordinary man will never understand the status of Serb Krajina without being explained what the Military Frontier in the Austrian Empire was. Moreover, following contemporary Western conceptions the reviewed book pays attention to the Battle at Kosovo Polje of 1389 as an element of a Serbian national myth. However, 
during the appearance of a national idea, as it was in every part of Yugoslavia in the late 1980s - early 1990s, a range of myths shaped national history. I have to admit that the Bosniaks have their own national narratives, as well as the Croatians and the Kosovo-Albanians. Their narratives are probably much more mythologised then the Serbian one. The question is why Western historians concentrate only on the Serbian narrative?

Referring to Russia of the 1990s, I doubt that international relations had any «progression» (see the above statement). At that time Russia had just ceded Serbia to the Western countries, at least until «Primakov's loop» on 24 March 1999.

I could agree with the idea that the Balkan countries are the «backyards» of Europe. Even integration within the European Union does not convert these countries from the European «powder keg» into «the old good Europe».

Рецензия поступила в сентябре 2015 г. 
Научное издание

\title{
АКТУАЛЬНЫЕ ПРОБЛЕМЫ МЕЖДУНАРОДНЫХ ОТНОШЕНИЙ И ГЛОБАЛЬНОГО РАЗВИТИЯ
}

\author{
Сборник научных статей \\ Выпуск 3 \\ В авторской редакции
}

Ответственные за выпуск Л. С. Больщедворова, Е. А. Логвинович Компьютерная верстка Л. С. Большедворовой

Корректор Е. И. Бондаренко

Подписано в печать 15.12.15. Формат 60 $84 / 16$.

Бумага офсетная. Ризография. Усл. печ. л. 17,67. Уч.-изд. л. 18,4. Тираж 100 экз. Заказ 000.

Белорусский государственный университет.

Свидетельство о государственной регистрации издателя, изготовителя, распространителя печатных изданий № 1/270 от 03.04.2014.

Пр. Независимости, 4, 220030, Минск.

УП «Бестпринт». ЛП № 02330/0494209 от 03.04.2009.

Ул. Филатова, 9. к. 1., 220026, г. Минск. 